GUSTAVO HENRIQUE DE OLIVEIRA

\title{
A RESPONSABILIDADE CIVIL DOS PAIS PELOS ATOS ILÍCITOS PRATICADOS PELOS SEUS FILHOS CAPAZES
}

\author{
DisSERTAÇão de Mestrado
}

Orientadora: Profa. Dra. Patrícia Faga Iglecias Lemos

FACULDADE DE DIREITO DA USP

SÃO PAULO

2011 
GUSTAVO HENRIQUE DE OLIVEIRA

\section{A RESPONSABILIDADE CIVIL DOS PAIS PELOS ATOS ILÍCITOS PRATICADOS PELOS SEUS FILHOS CAPAZES}

Dissertação de Mestrado apresentada à Banca Examinadora da Faculdade de Direito da Universidade de São Paulo, como exigência parcial para a obtenção do título de Mestre em Direito, sob orientação do Profa. Dra. Patrícia Faga Iglecias Lemos.

FACULDADE DE DIREITO DA USP

SÃO PAULO

2011 


\section{Banca Examinadora}

Dra. Patrícia Faga Iglecias Lemos

Dr. Fernando Campos Scaff

$\overline{\text { Dr. João Rizardo Brandão Aguirre }}$ 


\section{Agradecimentos}

Gostaria de agradecer a todas as pessoas sem a ajuda das quais eu não poderia realizar esse trabalho:

à minha amada esposa, Luciana, grande e paciente incentivadora, pelo apoio e compreensão, mesmo nos momentos de ausência, companheira de hoje e sempre;

aos meus pais, Emanuel e Marcia, alicerce incondicional em todas as situações, principalmente pelos ensinamentos morais e de vida, e pelo esforço em sempre priorizar o meu progresso intelectual e espiritual;

aos meus irmãos, Marcelo e Anita, pela amizade demonstrada no período em que me dediquei a este trabalho;

à minha orientadora, amiga e mestra, Patrícia Faga Iglecias Lemos, não apenas pelos ensinamentos e orientações valiosos, mas pelos significativos exemplos de caráter ímpar, dedicação e erudição;

à professora, Teresa Ancona Lopes, pelas brilhantes e inesquecíveis aulas e pelo imenso profissionalismo demonstrado.

aos meus amigos, Antonio Benedito Nascimento e Maria Cristina Zucchi, pela inestimável ajuda prestada e incentivo ao meu desenvolvimento acadêmico e profissional;

ao meu amigo de mestrado, Silvano Andrade do Bomfim, pelo companheirismo e constante incentivo às pesquisas e aos debates;

- e, principalmente, a DEUS, que colocou essas pessoas maravilhosas no meu caminho e me deu a oportunidade e a capacidade para desenvolver o presente estudo.

Sem vocês, nada teria sido possível 


\section{RESUMO}

A responsabilidade civil, um dos mais importantes institutos do sistema jurídico, evoluiu sobremaneira no transcorrer da história. Passou da fase da vingança privada à Lei de Talião, desenvolveu-se até chegar ao conceito de culpa para, finalmente, culminar com a teoria objetiva que confere mais justiça nesse ramo jurídico.

Da mesma forma, a responsabilidade civil dos pais desenvolveu-se de maneira cíclica, iniciando-se de forma a dispensar o elemento subjetivo, perante o direito romano, para, posteriormente, incorporar a teoria subjetiva da responsabilidade civil dos genitores. Hodiernamente, após passar pela teoria objetiva indireta, em que havia uma presunção relativa de culpa, por parte dos progenitores, o texto normativo brasileiro perfilhou, com fundamento em expressa disposição legal, a responsabilidade independentemente de culpa, ou seja, a responsabilidade objetiva.

Não obstante toda essa evolução da responsabilidade civil, máxime com a consagração pela nossa Carta Magna do princípio do solidarismo social e a consequente colocação dos interesses da vítima, no centro do sistema desse instituto do direito das obrigações, a antecipada aquisição da capacidade de fato da pessoa e o prematuro rompimento do poder familiar podem dificultar, em muitos casos, a devida indenização de vítimas de atos ilícitos praticados por jovens adultos.

Ocorre que, o sistema jurídico pátrio, mesmo após a aquisição da plena capacidade de fato da pessoa natural, confere ao jovem adulto uma tutela especial, por meio de alguns institutos jurídicos, reconhecendo, por conseguinte, que a maioridade, por si só, não afasta a pessoa de um regime jurídico mais protetivo, uma vez que reconhece algumas peculiaridades na vida dessa pessoa.

A maior abertura do sistema civilista, por meio da consagração das cláusulas gerais e dos conceitos jurídicos indeterminados, aliados a uma interpretação sistemática e analógica do instituto da responsabilidade civil por fato de outrem, a nosso ver, permite uma extensão da responsabilidade civil dos pais, mesmo após o atingimento da capacidade de fato de seus filhos, desde que estes últimos vivam sob a dependência econômica de seus genitores.

Essa responsabilidade surge da extração da essência da responsabilidade civil indireta, manifestada pelos vocábulos dependência e subordinação e da extensão do poder familiar, nas circunstâncias fáticas relatadas, conjugada com o risco inerente dessa atividade, somada à imperiosa necessidade de indenizar a vítima de um dano qualquer.

Palavras-chave: responsabilidade civil; dependência econômica, subordinação, extensão do poder familiar, indenização à vítima. 


\section{RIASSUNTO}

La responsabilità civile, uno dei più importanti istituti del sistema giuridico, ha evoluito molto nel trascorrere della storia. Ha passato dalla fase della vendetta privata alla legge di taglione. Ha sviluppato fino ad arrivare al concetto della colpa per, alla fine, culminare con la teoria oggetiva che conferisce più giustizia a questo campo giuridico.

Allo stesso modo, la responsabilità dei genitori si è sviluppata di forma ciclica, iniziando di modo a dispensare l' elemento soggetivo nel diritto romano, per dopo incorporare la teoria soggetiva della responsabilità civile dei genitori. Attualmente, dopo aver passato dalla teoria oggetiva indiretta, in cui predominava una presunzione relativa di colpa dalla parte dei genitori, il testo normativo brasiliano ha adottato, in base a una espressa disposizione legale, la responsabilità indipendentemente della colpa, cioè, la responsabilità oggettiva.

Nonostante tutta questa evoluzione della responsabilità civile, principalmente con la consagrazione dalla nostra Costituzione del principio del solidarismo sociale e la conseguente preoccupazione maggiore con gli interessi della vittima, l'acquisizione precoce della piena capacità della persona ai 18 anni e la rottura prematura della patria potestà, in molti casi, ha fatto con che la giusta indennizzazione della vittima di un atto illecito praticato da un giovane adulto sia diventato più difficile.

Il sistema giuridico, tuttavia, anche se dopo l'acquisizione della piena capacità della persona naturale, conferisce al giovane adulto una tutela speciale, da parte di alcuni istituti giuridici, riconoscendo, dunque, che la sola maggioranza non esclude questa persona di un regime giuridico più protettivo, già che riconosce alcune peculiarità nella sua vita.

La maggiore apertura del sistema civile, in ragione della consagrazione delle clausole generali e dei concetti giuridici a contenuto indeterminato, alleati a una interpretazione sistematica e analogica dell'istituto della responsabilità civile indiretta, nella nostra opinione, permettono una estensione della responsabilità civile dei genitori, anche dopo l'acquisizione della piena capacità dei figli, quando essi continuano a vivere nella dipendenza economica dei loro genitori.

Tutta questa responsabilità emerge dal riconoscimento della essenza della responsabilità civile indiretta, espressa dalle parole "dipendenza" e "subordinazione" e anche in ragione dell' estenzione della patria potestà nelle circostanze segnalate, sommato al rischio inerente di questa ativittà e con la prevalente necessità di indennizzare la vittima di un danno.

Parole chiave: responsabilità civile; dipendenza economica, subordinazione, estensione della patria potestà, indennizzazione della vittima. 


\section{SUMÁRIO}

INTRODUÇÃO

\section{REPERSONALIZAÇÃO DO DIREITO - A CONSTITUCIONALIZAÇÃO DO} DIREITO CIVIL

1.1. Breve estudo sobre a repersonalização do direito. A constitucionalização do direito civil

1.2. O jusnaturalismo, o positivismo, o pós-positivismo e as consequências na hermenêutica jurídica.

2. PERSONALIDADE JURÍdICA E A CAPACIDADE. 38

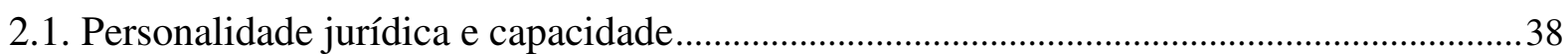

2.2. Capacidade e incapacidade dos menores na prática dos atos jurídicos ................................43

2.3. A emancipação .48

3. DO PODER FAMILIAR.

4. MUDANÇAS NA ESTRUTURA DAS FAMÍLIAS BRASILEIRAS E NAS FONTES DO DIREITO PÁTRIO

5. A RESPONSABILIDADE CIVIL

5.1. Breves considerações históricas a respeito da responsabilidade civil dos pais ... .96

5.2. Da responsabilidade civil objetiva.. 106

5.3. A responsabilidade civil indireta e dos pais 124

6. TEORIAS SOBRE O NEXO DE CAUSALIDADE 175

CONSIDERAÇÕES FINAIS 196 


\section{INTRODUÇÃO}

O instituto da responsabilidade civil dos pais, ${ }^{1}$ no decorrer da história, tem passado por transformações que corroboram a tendência pendular da ciência do direito como um todo. Sinteticamente, poder-se-ia dividir a evolução da responsabilidade civil, em nosso sistema em três fases: de aplicação do direito romano, a fase de implementação do direito criminal, em sede de responsabilidade civil, e a da sistematização da indenização no direito civil. $^{2}$

Com efeito, o fenômeno da responsabilidade civil, em geral, desenvolveu-se perante a ciência jurídica, de maneira cíclica, haja vista a assunção de diferentes características em períodos históricos diversos, ora possuindo certos atributos e elementos, ora negando-os para posteriormente realocá-los em sua estrutura. Ou seja, aquilo que fora outrora abandonado volta a ser aplicado. ${ }^{3}$

A essência da responsabilidade civil está, principalmente, em um dos três preceitos considerados como princípios fundamentais do direito, que foram proclamados pelo

\footnotetext{
1“'Ao lado da responsabilidade normal, pela qual cada um não é chamado a indenizar senão o dano que ele próprio produziu, a lei reconhece uma responsabilidade por fato ilícito alheio, isto é, chama a responder determinadas pessoas pelos danos ocasionados, quer por obra de terceiros que daqueles dependam, quer por obra dos animais ou de coisas inanimadas que estejam em seu poder" (grifos nossos). DE RUGGIERO, Roberto. Instituições de direito civil. Atualizado por Paulo Roberto Benasse. 1. ed. Campinas: Bookseller, 1999. v. 3, p. 599.

2“"Em nosso país, a responsabilidade civil passou por fases distintas: na primeira, as Ordenações do Reino mandavam aplicar subsidiariamente o direito romano ao direito pátrio, por intermédio da denominada 'Lei da Boa Razão' (Lei de 18.08.1769); na segunda, aplicou-se a idéia de ressarcimento à noção de 'satisfação', regulada pelo Código Criminal de 1830; na terceira, Teixeira de Freitas opôs-se à existência de uma responsabilidade civil germinada à criminal (art. 799 da Consolidação das Leis Civis), passando a satisfação do dano causado a ter lugar próprio: a legislação Civil.” CAMBLER, Everaldo. Curso avançado de direito civil: direito das obrigações. São Paulo: Ed. Revista dos Tribunais, 2001. v. 2, p. 259.

${ }^{3}$ A responsabilidade civil extracontratual, por fato de terceiro, no Direito Romano, trazia a possibilidade da responsabilidade objetiva do pater familias por delitos privados perpetrados por pessoa que estivesse sob sua potestas. É imperioso reconhecer que, em tal hipótese, aplicava-se o princípio da noxalidade. O pater famílias poderia ser demandado em ação delitual, vez que o filius ou escravo não tinham capacidade processual, optando pela defesa do alieni iuris ou liberar-se entregando a qualquer momento o autor do fato ao poder da pessoa lesada (noxalis deditio). RODRIGUES, Dárcio Roberto Martins. Contribuição para o estudo da responsabilidade por fato de terceiro no direito romano. 1996. Tese (Doutorado) - Faculdade de Direito, Universidade de São Paulo, São Paulo, 1996. p. 3-4. Ou seja, vislumbramos, a partir da referida assertiva que, naquela época, a responsabilidade do pater famílias era independente de culpa, ou seja, objetiva. Posteriormente, o instituto da responsabilidade evolui de forma a chegar-se na noção de culpa com a "Lex Aquilia de Damno". Mais tarde, com o desenvolvimento de uma sociedade complexa e perigosa, chega-se a prescindir da culpa como elemento indispensável para a eclosão do dever de reparar o dano com o ressurgimento, consequentemente, da responsabilidade objetiva.
} 
jurisconsulto romano Ulpiano. São eles: neminem laedere (a ninguém se deve lesar); honeste vivere (viver honestamente) e suum cuique tribuere ( dar a cada um o que é seu). ${ }^{4}$

Sobreleva ressaltar que todas essas etapas serão estudadas com mais vagar no decorrer deste estudo, porquanto cada uma das fases acima mencionadas possui sub-fases que demonstram aspectos importantes a serem considerados para a elucidação do tema proposto.

Cumpre enfatizar, por necessário, que o instituto da responsabilidade civil, com o avanço significativo do seu alcance, nos últimos anos, passou a se caracterizar como um dos mais expressivos e relevantes capítulos de toda a ciência jurídica, podendo-se dizer, sem qualquer receio de errar, que o tema ocupa a essência de todo o direito civil. ${ }^{5}$

Há preocupação sobre o tema em quase todas as atividades humanas, motivo pelo qual se exige, dos operadores desse ramo do direito das obrigações, debates e pesquisas intermináveis.

Não é sem razão que Aguiar Dias, em uma de suas obras, assevera que "toda a manifestação da atividade humana traz em si o problema da responsabilidade" 6

\footnotetext{
${ }^{4}$ De acordo com Nelson Nery Junior: "Os preceitos romanos honeste vivere, alterum non laedere, suum cuique tribuere (viver honestamente, não causar dano a outrem e dar a cada um o que é seu), são os primórdios dos princípios gerais de direito." NERY JUNIOR, Nelson. Contratos no Código Civil. In: FRANCIULLI NETTO, Domingos; MENDES, Gilmar Ferreira; MARTINS FILHO, Ives Granda da Silva (Coord.). O novo Código Civil: estudos em homenagem ao Prof. Miguel Reale. São Paulo: LTr, 2003. p. 406. Nas palavras de R. Limongi França: "Henri e Léon Mazeud, no seu clássico Traité Theorique et Pratique de la Responsabilité Civile (Paris, 1934) assinalavam que tal é a importância da matéria que se encontraria em vias de absorver todo o direito. Evidente o exagero dessa observação. Não obstante, a simples idéia de estar ligada ao conceito de dano nos leva a um dos três fundamentais juris praecepta, a saber, o alterum non laedere. Por outro lado, tendo havido a laesio alteri, é necessário cumprir o outro preceito, qual seja, o de suum cuique tribuere. Finalmente, o cumprimento dessa obrigação faz parte do honeste vivere." FRANÇA, Rubens Limongi. Manual de direito civil. São Paulo: Ed. Revista dos Tribunais, 1969. v. 4, t. 2, p. 276.

5“A responsabilidade civil conquistou inegável importância prática e teórica no Direito Moderno. Não é mais possível ignorá-la. Outrora circunscrita ao campo dos interesses privados, hoje a sua seara é das mais férteis, expandindo-se pelo direito público e privado, contratual e extracontratual, aéreo e terrestre, individual e coletivo, social e ambiental, nacional e internacional. Pode-se dizer que os seus domínio são ampliados na mesma proporção em que se multiplicam os inventos, as descobertas e outras conquistas da atividade humana. Alguns princípios da responsabilidade civil ganharam status de norma constitucional após a Carta de 1988, sem falar no enriquecimento que lhe trouxe a edição do Código de Proteção e Defesa do Consumidor, que regula todas as relações de consumo, em seus múltiplos aspectos. Prova disso é a vastíssima literatura jurídica sobre o inesgotável tema da responsabilidade civil e a extraordinária freqüência com que os tribunais são chamados a decidir conflitos de interesses nessa área. Já tive a oportunidade de constatar, por muitas vezes, que, numa sessão de julgamento, quase cinqüenta por cento dos recursos envolviam matéria de responsabilidade civil." CAVALIERI FILHO, Sérgio. Programa de responsabilidade civil. 7. ed. São Paulo: Atlas, 2007. p. 17.

${ }^{6}$ DIAS, José de Aguiar. Da responsabilidade civil. 9. ed. Rio de Janeiro: Forense, 1994. v. 1, p. 1.

Antônio Chavez leciona que: "Não há, a rigor, contrato, atividade, ato, até mesmo abstenção, que não contenha o gérmen da responsabilidade criminal ou civil". CHAVES, Antônio. Responsabilidade civil. Rio de Janeiro: José Bushatsky Editor, 1972. p. 17.
} 
O Código Civil de 2002 acompanhou a evolução do instituto da responsabilidade civil, criando uma dualidade quase que coexistencial entre a responsabilidade civil subjetiva e a objetiva, dualismo que produziu efeitos no campo da responsabilidade civil dos pais pelos atos de seus filhos incapazes, elidindo a vetusta presunção de culpa e perfilhando, expressamente, a responsabilidade civil objetiva. ${ }^{7}$

A exclusão do elemento culpa, em muitos casos potencialmente indenizáveis, representou a preocupação do pensamento contemporâneo da sociedade em colocar a vítima no centro da discussão do instituto em testilha ${ }^{8}$, proporcionando uma máxima garantia aos seus direitos, mormente o de ser indenizada sempre que sofra algum tipo de lesão.

A evolução da responsabilidade civil resulta do progresso do direito que busca acompanhar o desenvolvimento da sociedade que, nos últimos duzentos anos, passou por transformações que a tornaram tecnologicamente complexa e substancialmente perigosa, ${ }^{9}$ aumentando, sobremaneira, a ocorrência de eventos danosos com crescente dificuldade de se imputar a alguém a conduta geradora do dever de indenizar aquele que foi lesionado.

\footnotetext{
7،Atualmente, depara-se o aplicador da norma jurídica com um sistema de responsabilidade civil complexo, no qual convivem duas orientações que outrora chegaram a ser consideradas antagônicas: a responsabilidade com culpa e a responsabilidade sem culpa." LISBOA, Roberto Senise. Manual de direito civil: obrigações e responsabilidade civil. São Paulo: Ed. Revista dos Tribunais, 2004. v. 2, p. 446.

${ }^{8}$ Fala-se, também, na responsabilidade civil supedaneada no ato danoso em si. Nesse sentido, são as lições de Regis Fchtner Pereira para quem: "O eixo sobre o qual girava o sistema, portanto, era o do comportamento do autor do fato danoso. A vítima exercia um papel absolutamente secundário na determinação do dever de responder pelos danos a ela causados. A doutrina moderna vem modificando esse estado de coisas, deixando de centrar o sistema na figura do comportamento do autor do dano, e passando a centrá-lo no evento danoso em si. A responsabilidade civil vem sendo redefinida, assim, como uma reação contra o dano injusto". PEREIRA, Regis Fichtner. A responsabilidade civil pré-contratual: teoria geral e responsabilidade pela ruptura das negociações contratuais. Rio de Janeiro: Renovar, 2001. p. 38. Em aula proferida na USP, no dia 24/03/10, no Curso Visão Dinâmica da Responsabilidade Civil, quando explanava acerca do nexo de causalidade, a Professora Teresa Ancona Lopez lecionou que: "A vítima hoje deve ser indenizada de qualquer forma".

9“No processo de modernização, cada vez mais forças destrituivas também acabam sendo desencadeadas, em tal medida que a imaginação humana fica desconcertada diante delas. Ambas as fontes alimentam uma crescente crítica da modernização, que, ruidosa e conflitivamente, define os rumos das discussões públicas". BECK, Ulrich. Sociedade de risco: rumo a uma outra modernidade. Tradução de Sebastião Nascimento. São Paulo: Ed. 34, 2010. p. 25. Para Lucas de Abreu Barroso: "Indubitavelmente, a complexa estrutura social de nossos tempos - corolário do desenvolvimento científico, do progresso técnico e da evolução dos processos econômicos -, paralelamente ao incremento de inúmeras possibilidades de vida antes jamais experimentadas, entronizou uma perspectiva da qual não pode afastar-se em suas formulações teóricas e normativas à Ciência Jurídica: "a sociedade do risco" (Risicogesellschaft). A Revolução Industrial e, sobretudo, a Era Tecnológica fomentaram padrões socioeconômicos que estão a propor no mundo de hoje e do futuro seus próprios problemas. Dentre estes, ressalta-se uma enorme agravação dos riscos a que fica sujeita a pessoa humana". In BARROSO, Lucas de Abreu. Novas fronteiras da obrigação de indenizar. In: DELGADO, Luiz Mario; ALVES Jones Figueiredo (Coords.). Questões controvertidas no novo Código Civil (Responsabilidade civil). São Paulo, 2006. v. 5, p. 360.
} 
Assim, vive-se em uma sociedade de riscos em que as atividades modernas são altamente perigosas. Essa situação potencializa, de alguma forma, o surgimento de danos a todo instante.

Ademais, o princípio da Universalidade da Jurisdição se preocupa com o implemento de uma tutela cada vez mais eficiente, efetiva e eficaz, ${ }^{10}$ pois possibilitar o acesso ao Poder Judiciário, por meio do direito de ação, sem a necessária eficácia de modificar a realidade jurídica, quando há necessidade, é a mesma coisa que não garanti-lo, acesso este consagrado, como é cediço, a direito fundamental individual, ${ }^{11}$ previsto no art. $5^{\circ}$, XXXV, da nossa Carta Magna. ${ }^{12}$

Ainda na esfera constitucional, a importância do instituto sob análise é mais acentuado a partir de sua inserção no próprio rol dos direitos individuais do art. $5^{\circ}$ da $\mathrm{CF} / 88$ que, em seus incisos $\mathrm{V}$ e $\mathrm{X}$ aduzem, respectivamente que "é assegurado o direito de resposta, proporcional ao agravo, além de indenização por dano material, moral ou à imagem" e "são invioláveis a intimidade, a vida privada, a honra e a imagem das pessoas,

\footnotetext{
${ }^{10}$ Luiz Rodrigues Wambier, Flávio Renato Correia de Almeida e Eduardo Talamini asseveram, quando tratam do instituto da tutela antecipada, que tem este instrumento processual índole nitidamente constitucional, haja vista o fato de que por vezes o tempo despendido no curso regular de uma ação pode trazer consequências desastrosas ao jurisdicionado. A tutela antecipada foi uma maneira encontrada pelo legislador de mitigar os eventuais danos ocasionados pelo fator tempo no processo, possibilitando a sua eficácia, porquanto garantir o acesso de todos perante um Poder Judiciário ineficiente é a mesma coisa que não garantir. É mister reconhecer que o sistema tem se preocupado cada vez mais com a efetividade processual, de forma a permitir a sua máxima utilidade implementando, desta forma, de fato, o princípio da universalização da jurisdição previsto no art. 5, XXXV, da Constituição Federal de 1988. WAMBIER, Luiz Rodrigues; ALMEIDA, Flávio Renato Correia de; TALAMINI, Eduardo. Curso avançado de processo civil. 8. ed. São Paulo: Ed. Revista dos Tribunais, 2006. v. 1, p. 303.

${ }^{11}$ Os constitucionalistas, de uma forma geral, conceituam os direitos fundamentais como sendo aqueles indispensáveis à pessoa humana, necessários para asseguram a todos uma existência digna, livre e igual. Vale a pena explicitar, ainda, que os denominados direitos fundamentais pertencem a um gênero, de que são espécies os direitos individuais, os direitos sociais, os direitos coletivos, os direitos políticos e os direitos de nacionalidade.

Nas lições de Paulo Bonavides: "Os direitos fundamentais são a bússola das Constituições. A pior das inconstitucionalidades não deriva, porém, da inconstitucionalidade formal, mas da inconstitucionalidade material, deveras contumaz nos países em desenvolvimento ou subdesenvolvidos, onde as estruturas constitucionais, habitualmente instáveis e movediças, são vulneráveis aos reflexos que os fatores econômicos, políticos e financeiros sobre elas projetam". BONAVIDES, Paulo. Curso de direito constitucional. 13. ed. São Paulo: Malheiros Ed., 2003. p. 601.

José Afonso da Silva disserta que: "Direitos fundamentais do homem constitui expressão mais adequada a este estudo, porque, além de referir-se a princípios que resumem a concepção do mundo e informam a ideologia política de cada ordenamento jurídico, é reservada para designar, no nível do direito positivo, aquelas prerrogativas e instituições que ele concretiza em garantias de uma convivência digna, livre e igual de todas as pessoas. No qualificativo fundamentais acha-se a indicação de que se trata de situações jurídicas sem as quais a pessoa humana não se realiza, não convive e, às vezes, nem mesmo sobrevive...". SILVA, José Afonso. Curso de direito constitucional positivo. 12. ed. São Paulo: Malheiros Ed., 1996. p. 176-177.

${ }^{12} \mathrm{CF} / 88$, Art. $5^{\circ}$, XXXV- a lei não excluirá da apreciação do Poder Judiciário lesão ou ameaça a direito.
} 
assegurado o direito à indenização pelo dano material ou moral decorrente de sua violação".

Destarte, em algumas circunstâncias, o ordenamento jurídico pátrio cria deveres de indenizar até mesmo a quem não praticou conduta adequada a produzir dano à esfera jurídica de terceiros, ou seja, sem a presença do nexo causal, como na hipótese contemplada no artigo 735 do Código Civil, ${ }^{13}$ que cuida da responsabilidade contratual do transportador, quando assevera que ele (transportador) responderá pelo dano ocasionado em seu passageiro, ainda que o prejuízo tenha sido causado por culpa exclusiva de terceiros.

Dessa forma, hodiernamente, busca-se com mais nitidez um responsável pelo prejuízo, prescindindo-se não rara vez da culpa para a eclosão da obrigação de reparar, porquanto muitas vezes esse elemento subjetivo, mormente a partir da complexidade atual da vida social, passou a inviabilizar a indenização em muitos casos.

Vislumbra-se dessa forma uma evolução social no sentido de se perscrutar sempre em quem deve recair a responsabilidade pelos danos ocorridos, dado o fato de que a vítima, no momento, assumiu uma posição de destaque perante o sistema da responsabilidade civil. ${ }^{14}$ Arredou-se o pensamento da sociedade de que as pessoas deveriam aceitar as vicissitudes da vida por serem desígnios de Deus. ${ }^{15}$

Ademais, o princípio da solidariedade, insculpido no artigo $3^{\circ}$, I, da Constituição Federal, permitiu um tratamento diferenciado a institutos tradicionais do direito civil e, no caso em debate, da responsabilidade civil, pois trouxe à baila uma preocupação maior com a necessidade de tornar indene a vítima de um ato ilícito.

\footnotetext{
13“Art. 735. A responsabilidade contratual do transportador por acidente com o passageiro não é elidida por culpa de terceiro, contra o qual tem ação regressiva".

${ }^{14}$ De acordo com Teresa Ancona Lopes: "Hoje, mais do que nunca, os direitos da pessoa se acham terrivelmente ameaçados não só pelo assustador progresso tecnológico mas, principalmente, pela falta de solidariedade e respeito dentro da sociedade moderna, caracterizada, infelizmente, por todos os tipos de violência”. LOPEZ, Teresa Ancona. $O$ dano estético: responsabilidade civil. 2. ed. São Paulo. Ed. Revista dos Tribunais, 1999. p. 15.

${ }^{15}$ No escólio de Fernando Noronha, no que tange à responsabilidade civil, os riscos foram demasiadamente agravados com a Revolução Industrial, em comparação com os perigos de antigamente, fato este que fez crescer as interpelações judiciais com o objetivo de reparação dos danos advindos desta circunstância. Com efeito, o fornecimento de bens e de serviços, mormente o de educação, ocasionou uma valorização maior do ser humano, fazendo com que ele começasse a aceitar menos as vicissitudes do destino, refutando a desgraça e exigindo compensação pela lesão sofrida. NORONHA, Fernando. Desenvolvimentos contemporâneos da responsabilidade civil. Revista dos Tribunais, São Paulo, ano 88, v. 761, p. 35, mar. 1999.
} 
Assevera Maria Celina Bodin de Moraes, ao explanar as diferenças ideológicas existentes entre os séculos XIX e o XX, que o primeiro expressou a vitória do individualismo, considerando o indivíduo objeto de orgulho e confiança de acordo com sua potencialidade criativa intelectual e seu esforço como pessoa. Por outro lado, a partir do século XX, a sociedade soçobrou esse pensamento egoísta, colocando a solidariedade social como a forma mais condizente com os anseios sociais, após experiências degradantes da humanidade, no transcorrer da Segunda Guerra Mundial. ${ }^{16}$

Além do mais, a evolução da sociedade de massa e industrializada permitiu o surgimento de discussões em torno dos elementos imprescindíveis para a deflagração do dever de indenizar, aparecendo, como é cediço, a responsabilidade objetiva fundamentada na teoria do risco, que já atingiu várias subteorias e que serão objeto de maior análise oportunamente.

Assim, os tradicionais elementos da responsabilidade civil que, perante o Código Civil de 1916, se agrupavam de uma forma quase que absolutamente fechada, dando, por um lado, maior segurança ao jurisdicionado e, por outro, proporcionando muitas injustiças, ${ }^{17}$ sofreram algumas modificações, abrindo-se um flanco que permitirá maiores discussões em cada caso concreto.

A responsabilidade objetiva, derivada do exercício de atividade perigosa, por sua natureza, estampada no parágrafo único do artigo 927 do novo Código Civil como uma das formas de se responsabilizar sem o elemento subjetivo, permitiu e permitirá acirrados debates em torno dos verdadeiros limites da responsabilidade civil no ordenamento jurídico brasileiro e no campo do nosso presente estudo, da viabilidade de se responsabilizar os pais pelos danos ocasionados por seus filhos maiores que vivam sob sua dependência econômica.

A redução da idade de 21 para 18 anos, no que tange ao atingimento da capacidade civil plena, perante o Código Civil de 2002, possibilitou uma libertação mais precoce pelos

\footnotetext{
${ }^{16}$ MORAES, Maria Celina Bodin de. O princípio da solidariedade. Disponível em: $<$ www.idcivil.com.br/pdf/biblioteca9.pdf>. Acesso em: 07 maio 2009.

${ }^{17}$ Guido Fernando da Silva Soares, ao explanar a respeito do sistema da Civil Law aduz que: "A equidade, aquela virtude de temperar o rigor da lei, que força tanto o legislador quanto o juiz a lembrar que o direito é uma construção que tem sua validade, na medida em que realiza os valores transcendentais de justiça (o suum cuique tribuere), frontalmente proíbe que se satisfaça o disposto na lei, se houver ofensa à idéia magna da realização da justiça." SOARES, Guido Fernando da Silva. Common law: introdução ao direito dos EUA. São Paulo: Ed. Revista dos Tribunais, 1999. p. 30.
} 
pais dos encargos do poder familiar e, conseguintemente, permitiu a assunção pelos filhos da responsabilidade por atos danosos praticados, ainda que vivam com os pais, não trabalhem, apenas estudem e não possuam idoneidade financeira para arcar com os danos causados na esfera jurídica de terceiros.

Se, por um lado, a mudança legislativa, engendrada pela nova codificação, mostrou-se correta em razão do desenvolvimento dos meios de comunicação que permitem uma maior maturidade vivencial do indivíduo, por outro trouxe uma preocupação quanto às consequências desse amadurecimento precoce perante a vida social.

Dessa forma, a antecipação da maioridade pode provocar e tem provocado, como noticiam os órgãos midiáticos, ${ }^{18}$ graves e insolúveis problemas para a ciência do direito, com vistas à possibilidade dessas pessoas, recém saídas da menoridade, praticarem atos contrários ao direito, ensejadores da eclosão de responsabilidade civil, sem o necessário aporte financeiro para arcarem com esses ônus.

Nessa linha, emerge translúcida a impossibilidade da indenização, porquanto quase sempre o ocasionador do dano não possui patrimônio próprio idôneo a ressarcir a lesão causada, posto que essas pessoas vivem praticamente como dependentes de seus genitores, que lhe cedem veículos para a locomoção e numerário para a sobrevivência (espécies contratuais como será averiguado) sem a garantia de um lastro capaz de sustentar a assunção da responsabilidade. ${ }^{19}$

\footnotetext{
${ }^{18}$ Recorde-se o caso do índio pataxó em Brasília, em que jovens de classe média atearam fogo em um silvícola por pura diversão e o mataram. Outro caso, muito divulgado e mais recente, foi aquele em que jovens no Rio de Janeiro espancaram uma mulher no ponto de ônibus com a escusa de que para eles era parecia ser uma prostituta. Na avenida Paulista, recentemente, cinco jovens de classe média atacaram um rapaz com uma lâmpada fluorescente por motivos de homofobia.

${ }^{19}$ A Juíza Maria Ángeles Callizo López, ao tratar das mudanças legislativas atinentes à pensão alimentícia em Zaragoza, que a estendeu aos filhos maiores até a idade de 26 anos, assevera que: "Respecto de los alimentos legales de los hijos mayores de edad o emancipados, la propia realidad social, conforme a la cual se han de interpretar lãs normas jurídicas, demuestra que los hijos, aún adquirida la mayoría de edad, continúan bajo la dependencia económica de los padres, fundamentalmente por dos motivos: primero, porque normalmente la formación académica de un menor, que constituye un elemento imprescindible para acceder a un puesto de trabajo de cierta cualificación, termina aproximadamente entre los veintedós y veintecuatro años, y segundo, por la especial dificultad que supone en la actualidad el acceso al mercado laboral, a un puesto de trabajo estable y adecuado, con el objeto de obtener unos ingresos que le permiten llevar uma vida independiente de sus progenitores". CALLIZO LÓPES, Maria Ángeles. Obligación legal de alimentos respecto de los hijos mayores de edad: análisis del Artículo 66 de la Ley 13/2006, de 27 de diciembre, de Derecho de la Persona. Revista de Derecho Civil Aragonés, Zaragoza, año 28, p. 68-69, 2009.
} 
A propósito, Maria Helena Diniz, consciente dos problemas vindouros a respeito da antecipada aquisição da maioridade civil, leciona que o novel diploma civil passou a concedê-la aos 18 anos, produzindo efeitos tanto no instituto da responsabilidade civil, que terá protagonistas mais jovens, em tese, aptos a arcar com os danos ocasionados a terceiros, quanto no mundo dos atos e negócios jurídicos, vez que ao reconhecer o sistema a precoce libertação do indivíduo da especial proteção destinada aos incapazes de expressar validamente suas vontades, expressada muitas vezes por meio do instituto do poder familiar, possibilitou o gerenciamento de sua própria vida, sem a intromissão de qualquer pessoa. $^{20}$

Essa antecipação deu-se em virtude do avanço tecnológico do mundo moderno que conferiu à pessoa novos, disponíveis e eficientes meios de comunicação, permitindo um desenvolvimento mais acelerado do indivíduo em seu aspecto intelectual, tornando-o mais maduro e produzindo, consequentemente, a capacidade de atingir o necessário discernimento para a prática dos atos da vida civil, independentemente da co-participação de qualquer outra pessoa na realização de atos ou negócios jurídicos. ${ }^{21}$

Apesar das vantagens surgidas a partir da redução da maioridade para a idade de 18 anos, diferentemente dos 21 anos estabelecido pela antiga lei civil, alguns desconfortos serão percebidos, ao longo do tempo, em virtude do desprendimento antecipado das amarras do poder familiar.

Nesse diapasão, a obrigatoriedade de reparar os danos morais e materiais causados na esfera jurídica de terceiros, sem a ajuda dos pais, em virtude da cessação antecipada do poder familiar, dificultará, abstratamente, a possibilidade de indenização da vítima, haja vista a dificuldade natural que o ser humano encontra, nessa fase da vida, de angariar patrimônio sólido para ressarcir eventuais prejuízos causados a outrem. "Será que o jovem de 18 anos teria mesmo, apesar de bem informado, condições objetivas para arcar sozinho com tantas obrigações e responsabilidades?" 22

\footnotetext{
${ }^{20}$ DINIZ, Maria Helena. Curso de direito civil brasileiro: teoria geral do direito civil. 24. ed. São Paulo: Saraiva, 2007. p. 192.

${ }^{21}$ Id. Ibid.

${ }^{22}$ Id. Ibid., p. 192-193.
} 
Tudo a demonstrar a importância do presente tema, que requisitará pesquisas infindáveis dos aplicadores do direito, visando ao atingimento do bem jurídico mais perseguido por todos que militam na área jurídica, qual seja, a justiça. ${ }^{23}$

Com efeito, justiça formal, nas lições de Chain Perelman, consiste no tratamento igualitário conferido aos membros de uma mesma categoria. Distingue-se, dessa maneira, da justiça concreta que deixa de ser uma fórmula geral, aplicável a todos os casos, porquanto esta última já considera determinados fatores de tratamento diferenciados a serem aplicados dependendo da prioridade que se estabeleça às categorias, valorando melhor uns em detrimento de outros. ${ }^{24}$

Nesta dissertação, o ponto de partida é a salvaguarda dos interesses da vítima que, hodiernamente, é colocada no centro da discussão, atinente à responsabilidade civil, dandolhe deliberadamente preferência, e que tem como resultado a necessidade de todas as pessoas lesadas em seus interesses serem tratadas de forma igual, ou seja, de serem prioritariamente indenizadas. Fala-se, assim, em justiça formal e justiça concreta.

Por tais razões, faremos a abordagem a respeito da possibilidade do sistema jurídico pátrio albergar a hipótese dos pais indenizarem os atos ilícitos praticados por seus filhos capazes, desde que os mesmos vivam sob dependência econômica de seus genitores.

Para isso, optou-se, num primeiro momento, por tecer considerações sucintas sobre a repersonalização do direito e seus consectários legais, inclusive no que diz respeito ao tema referente à responsabilidade civil, avançando sobre as questões atinentes à personalidade jurídica, capacidade e emancipação das pessoas.

Posteriormente, serão discutidos o poder familiar, o nexo de causalidade, a mudança de estrutura das famílias brasileiras e o tema central sobre a responsabilidade civil dos pais, com enfoque na viabilidade de serem eles responsáveis civilmente pelos danos que seus filhos capazes causarem a terceiros desde que preenchidos certos requisitos já consagrados pelo ordenamento jurídico.

\footnotetext{
${ }^{23}$ De acordo com o escólio de Rosa Maria de Andrade Nery “...o sistema normativo pode conter regras injustas ou regras que possam gerar conseqüências injustas, e, então, é necessário ir além das regras, em busca da justiça”. NERY, Rosa Maria de Andrade. Introdução ao pensamento jurídico e à teoria geral do direito privado. São Paulo: Ed. Revista dos Tribunais, 2008.

${ }^{24}$ PERELMAN, Chain. Ética e direito. Tradução Maria Ermantina Galvão. São Paulo: Martins Fontes, 2000. p. 5-33.
} 


\section{REPERSONALIZAÇÃO DO DIREITO - A CONSTITUCIONALIZAÇÃO DO DIREITO CIVIL}

\subsection{Breve estudo sobre a repersonalização do direito. A constitucionalização do direito civil}

Atualmente, há doutrinadores civilistas e constitucionalistas que advogam a ideia da personalização e da constitucionalização do direito como um todo, mormente, do direito civil. $^{25}$

Tal assertiva transmite o pensamento de que o ser se tornou, com o passar dos tempos, mais importante que o ter. ${ }^{26}$ A pessoa humana ocupa o centro do sistema, sendo, dessa forma, a preocupação maior de proteção pelo ordenamento jurídico. ${ }^{27}$

Fala-se, sinteticamente, em repersonalização do direito civil e, por conseguinte, em sua despatrimonialização. ${ }^{28} \mathrm{O}$ valor dignidade da pessoa humana, preconizado na

\footnotetext{
${ }^{25}$ É quase impossível encontrar litígios judiciais em qualquer área (civil, penal, trabalhista, tributário, etc), hoje em dia, em que não são sejam invocadas normas jurídicas constitucionais pelos sujeitos do processo para fundamentar suas pretensões ou decisões. A Carta Magna de 1988 ganhou um papel de extremo destaque no cenário jurídico nacional, fato este que pode ser visualizado a partir da necessidade de se buscar sempre, pelos operadores do Direito, as interpretações da Constituição pelo STF, como forma de equacionar os problemas sociais. "A Constituição, enfim, está presente de várias maneiras no dia-a-dia das pessoas, como nunca antes esteve no país". SARMENTO, Daniel. Ubiqüidade constitucional: os dois lados da moeda. In: SARMENTO, Daniel Antonio de Moraes; SOUZA NETO, Cláudio Pereira (Orgs.). A constitucionalização do direito: fundamentos teóricos e aplicações especificas. Rio de Janeiro: Lumern Júris, 2007. p. 113-115.

26“"A marca do Direito Civil em nossa época é a maior consideração à pessoa: mais do que construir um conjunto de regras voltadas, primordialmente ao ter e ao agir, nós descobrimos - num verdadeiro giro antropocêntrico - que a pessoa, o ser, está no coração do direito civil". COSTA, Judith Martins. O adimplemento e o inadimplemento das obrigações no novo Código Civil e o seu sentido ético e solidarista. In: FRANCIULLI NETTO, Domingos; MENDES, Gilmar Ferreira; MARTINS FILHO, Ives Granda da Silva (Coord.). O novo Código Civil: estudos em homenagem ao Prof. Miguel Reale. São Paulo: LTr, 2003. p. 332.

${ }^{27 ،} \mathrm{O}$ Direito Civil, portanto, se constitucionalizou, apresentando forte carga solidarista e despatrimonializante, com atribuição de maior relevância à pessoa humana (o ser) do que ao seu patrimônio (o ter)". GAMA, Guilherme Calmon Nogueira da. Direito de família brasileiro: introdução. Abordagem sob a perspectiva civil-constitucional. São Paulo: Juarez de Oliveira, 2001. p. 27.

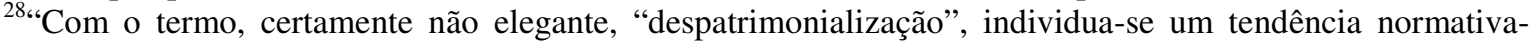
cultural; se evidencia que no ordenamento se operou uma opção, que, lentamente, se vai concretizando, entre personalismo (superação do individualismo) e patrimonialismo (superação da patrimonialidade fim a si mesma, do produtivismo, antes, e do consumismo, depois, valores). Com isso não se projeta a expulsão e a "redução" quantitativa do conteúdo patrimonial no sistema jurídico e naquele civilístico em especial; o momento econômico, como aspecto da realidade social organizada, não é eliminável. A divergência, não certamente de natureza técnica, concerne à avaliação qualitativa do momento econômico e à
} 
Constituição Federal de 1988, em seu artigo $1^{\circ}$, III, como princípio fundamental, exterioriza essa afirmação que foi muito bem assimilada pelo Código Civil de 2002. ${ }^{29}$

Nessa direção, a Carta Magna de 1988 impôs ao Direito Civil a renúncia ao caráter patrimonialista deixado como herança pelo século XIX, em especial pelo Código Napoleônico, adquirindo uma postura mais preocupada com o desenvolvimento humano e a sua dignidade, considerada concretamente em suas relações interpessoais, objetivando a sua emancipação. ${ }^{30}$

Dessa forma, principalmente em virtude da grande influência que possui em todo o sistema normativo, a Constituição Federal, modernamente, passa a ocupar juridicamente um papel de maior destaque, não sendo exagero mencionar até o surgimento de um novo ramo do direito, denominado por muitos de direito civil constitucional. ${ }^{31}$

Esse "novo ramo" do direito nada mais é que uma releitura do ordenamento civil com as "lentes" da Constituição, ou seja, com os valores previstos constitucionalmente que ingressaram no ordenamento jurídico por meio dos princípios constitucionais, de acordo com a doutrina constitucionalista. ${ }^{32}$

disponibilidade de encontrar, na exigência de tutela do homem, um aspecto idôneo, não a "humilhar" a aspiração econômica, mas, pelo menos, a atribuir-lhe uma justificativa institucional de suporte ao livre desenvolvimento da pessoa". PERLINGIERI, Pietro. Perfis do direito civil: introdução ao direito civil constitucional. 3. ed. Rio de Janeiro: Renovar, 2009. p. 33.

${ }^{29}$ De acordo com as lições de José Fernando Simão: "Da dignidade da pessoa humana decorrem os fenômenos da repersonalização e da despatrimonialização. A repersonalização reencontra a trajetória da longa história da emancipação humana, no sentido de repor a pessoa humana como centro do direito civil, passando o patrimônio para o papel de coadjuvante, nem sempre necessário”. SIMÃO, José Fernando. Responsabilidade civil incapaz. São Paulo: Atlas, 2008. p. 107.

No mesmo sentido, BARROSO, Luís Roberto. Neoconstitucionalismo e constitucionalização do direito (O triunfo tardio do direito constitucional no Brasil). In: SARMENTO, Daniel Antonio de Moraes; SOUZA NETO, Cláudio Pereira (Orgs.). A constitucionalização do direito: fundamentos teóricos e aplicações especificas. Rio de Janeiro: Lumern Júris, 2007. p. 217.

${ }^{30}$ FACHIN, Luiz Edson. Aspectos da racionalidade histórico-cultural do arquétipo inserido no Código Civil brasileiro de 2002. Revista do Advogado, São Paulo, ano 28, n. 98, p. 144, jul. 2008.

31"'A jurisprudência dos valores constitui, sim, a natural continuação da jurisprudência dos interesses, mas com maiores aberturas para com as exigências de reconstrução de um sistema de "Direito Civil constitucional", enquanto idônea a realizar, melhor do que qualquer outra, a funcionalização das situações patrimoniais àquelas existenciais, reconhecendo a estas últimas, em atuação dos princípios constitucionais, uma indiscutível preeminência”. PERLINGIERI, Pietro. op. cit., p. 32.

${ }^{32}$ A constitucionalização do Direito, no escólio de Daniel Sarmento, "envolve duas facetas distintas: (a) a Constituição passa a tratar, em maior ou menor detalhe, de temas que antes eram disciplinados pelo legislador, retirando uma série de decisões do alcance das maiorias legislativas de cada momento; e (b) os princípios e valores da Constituição penetram em todo o ordenamento jurídico, impondo uma "filtragem" constitucional do ordenamento, vale dizer, a releitura dos conceitos e institutos dos mais diversos ramos do Direito à luz da Constituição". SARMENTO, Daniel. op. cit., p. 122. 
O direito civil constitucional pode ser representado, também, pela interação entre o Direito Público e o Direito Privado, por meio da expressa previsão, em nossa Carta Magna, de institutos que pertencem tradicionalmente ao Direito Privado, o que culminou com a publicização deles, mormente em razão de mudanças ocorridas nas sociedades ocidentais no último século. ${ }^{33}$

É imperioso reconhecer, que o fenômeno de constitucionalização do direito civil não representou apenas a inserção no bojo da Lei Maior de alguns dos institutos mais importantes dessa área do Direito. ${ }^{34}$ Mais expressiva que a previsão em nossa Lei Suprema de alguns fundamentais institutos do direito privado foi a mudança causada pela Constituição Federal na interpretação do direito como um todo, revelando a necessidade de uma maior preocupação no momento de se extrair a norma jurídica, com a aplicação de princípios constitucionais que constituem a porta de entrada de valores ético-jurídicos enaltecedores, principalmente, da pessoa humana.

Assim, diferentemente do que ocorreu durante boa parte de vigência do Código Civil de 1916, após a entrada em vigor da $\mathrm{CF} / 88$, este documento político e jurídico, conceituado por Hans Kelsen como o fundamento de validade de todo o ordenamento jurídico, assumiu a centralidade do sistema, deslocando o Código Civil de sua posição de destaque.

Destarte, a CF/88 passou a irradiar seus efeitos para todo o direito infraconstitucional, mormente para o direito civil que, conseguintemente, abandonou valores ultrapassados e dissonantes com os impostos pela Carta Magna.

\footnotetext{
33“Atualmente, o Direito Civil não pode mais ser concebido sob a ótica individualista, tradicional, patrimonialista e conservadora-elitista da época das codificações. Seguindo tendência mundial, no direito brasileiro, é importante notar o indispensável e relevante papel da Constituição Federal no âmbito do Direito Privado. Aliás, cuida-se de mais um capítulo relativo à propalada dicotomia público/privado, abalando os alicerces edificados pela doutrina tradicional na Summa divisio do direito - direito público e direito privado". GAMA, Guilherme Calmon Nogueira da. op. cit., p. 25.

${ }^{34}$ Doutrinadores, como é o caso de Cláudio Pereira de Souza Neto e José Vicente Santos de Mendonça, falam em constitucionalização-inclusão, como sendo o fenômeno pelo qual é inserido na Constituição determinado conteúdo normativo, e em constitucionalização-releitura, em que se reinterpreta a ordem infraconstitucional em conformidade com a Lei Maior, ambos os conceitos inserem-se no fenômeno da constitucionalização do Direito. SOUZA NETO, Cláudio Pereira de; MENDONÇA, José Vicente Santos de. Fundamentalização e fundamentalismo na interpretação do princípio constitucional da livre iniciativa. In: SARMENTO, Daniel Antonio de Moraes; SOUZA NETO, Cláudio Pereira (Orgs.). A constitucionalização do direito: fundamentos teóricos e aplicações especificas. Rio de Janeiro: Lumern Júris, 2007. p. 710.
} 
Sobreleva ressaltar que o fenômeno da constitucionalização do direito está intimamente ligado ao reconhecimento da força normativa de nossa Lei Maior que, durante décadas, era considerada apenas um documento político que necessitava, para a produção de efeitos vinculantes, da intermediação do legislador. ${ }^{35}$ Ou seja, enquanto não se manifestasse o direito reconhecido na Carta Magna, por meio de lei infraconstitucional, os seus preceitos eram considerados apenas conselhos.

Fica evidente que a regra é: a Lei Suprema nunca pode ser interpretada a partir da legislação infraconstitucional. Não se pode admitir que a Constituição, com seu caráter inicial e inovador, tenha que se curvar diante do preconizado por legislações de inferior hierarquia. A Carta Magna é o ponto de partida do qual nasce toda a ordem jurídica. Configurar-se-ia um verdadeiro contrassenso aceitar que as normas de inferior hierarquia pudessem ditar seus comandos em detrimento dos preceitos constitucionais que, indubitavelmente, são os fundamentos de validade de todo o sistema jurídico. ${ }^{36}$

Dissertando a respeito da força normativa da Constituição, Luis Roberto Barroso aduz que o século XX presenciou uma das grandes alterações de paradigma que se refletiu no reconhecimento à norma constitucional de status de norma jurídica. Essa mudança representou a superação do modelo vigente na Europa, até meados do século passado, em que a Carta Magna não tinha força normativa, porquanto era considerada apenas um documento político, sendo um convite à atuação dos Poderes Públicos. A realização de seus comandos condicionava-se ao possível desempenho do legislador ou à discricionariedade do administrador. ${ }^{37}$

Após a $2^{\mathrm{a}}$ Guerra Mundial, ocorreu a reconstitucionalização de vários países europeus e, por conseguinte, a Constituição passa a desfrutar de maior importância, ocasionando a mudança de seu papel em relação ao ordenamento jurídico. Primeiramente na Alemanha e, com maior atraso, na Itália. Posteriormente em Portugal e na Espanha. Hoje, em dia, a premissa para o estudo do direito constitucional é o reconhecimento de que

\footnotetext{
${ }^{35}$ SAMPAIO, José Adércio Leite. Mito e história da Constituição: prenúncios sobre a constitucionalização do direito. In: SARMENTO, Daniel Antonio de Moraes; SOUZA NETO, Cláudio Pereira (Orgs.). A constitucionalização do direito: fundamentos teóricos e aplicações especificas. Rio de Janeiro: Lumern Júris, 2007. p. 199-200.

${ }^{36}$ BASTOS, Celso Ribeiro; MARTINS, Ives Gandra. Comentários à Constituição do Brasil. São Paulo: Saraiva, 1988. v. 1, p. 349-350.

${ }^{37}$ BARROSO, Luís Roberto. op. cit., p. 209.
} 
suas normas possuem caráter vinculante e imperativo, assim como qualquer outra norma jurídica. $^{38}$

Por fim, enfatiza que:

\begin{abstract}
"O debate acerca da força normativa da Constituição só chegou ao Brasil, de maneira consistente, ao longo da década de 80 , tendo enfrentado as resistências previsíveis. Além das complexidades inerentes à concretização de qualquer ordem jurídica, padecia o país de patologias crônicas, ligadas ao autoritarismo e à insinceridade constitucional. Não é surpresa, portanto, que as Constituições tivessem sido, até então, repositórios de promessas vagas e de exortações ao legislador infraconstitucional, sem aplicabilidade direta e imediata. Coube à Constituição de 1988, bem como à doutrina e à jurisprudência que se produziram a partir da promulgação, o mérito elevado de romper com a posição mais retrógrada". 39
\end{abstract}

Inobstante a consagração da força normativa da Constituição e a consequente irradiação por todo o sistema de seus preceitos e princípios jurídicos, não é razoável, de forma alguma, afirmar que o Direito Civil não continue possuindo posição de destaque em nosso ordenamento, mormente no sistema do direito privado, ${ }^{40}$ se é que ainda podemos dividir o direito em público e privado. ${ }^{41}$

A autonomia do Direito Civil não é destruída por esse fenômeno da constitucionalização do direito. Deve-se considerar que a Constituição é a regra máxima,

\footnotetext{
${ }^{38}$ BARROSO, Luís Roberto. op. cit., p. 209.

${ }^{39}$ Id., loc. cit.

${ }^{40}$ Renan Lotufo assevera que: "O Código Civil, como já dissemos repetidas vezes, não é mais o centro. A Constituição passou a ser o foco de informação. Mas nunca podemos deixar de lado que o Código também tem uma função participativa, intermédia entre a Constituição e os microssistemas. Esta atual tendência do direito em criar microssistemas não pode deixar de lado regras gerais, que nem sempre são reguladas por estas leis especiais, as quais, em geral, se amparam nos Códigos para regular situações específicas". LOTUFO, Renan. Da oportunidade da codificação civil. Revista do Advogado, São Paulo, ano 22, n. 68, p. 24-25, dez. 2002.

${ }^{41}$ Para José Fernando Simão "a dicotomia clássica entre os direitos público e privado tende paulatinamente a desaparecer. Deixa o Código Civil de ser o centro das relações do direito privado. Com a consciência da unidade do sistema e do respeito à hierarquia das fontes normativas, a Constituição assume seu lugar como base fundamental dos princípios do ordenamento. Isso porque o direito civil e o direito público estão, muitas vezes, em campos de convergência, o que coloca por terra os dois critérios tradicionais de distinção, os quais são os seguintes: critério do desequilíbrio das partes (o direito público seria caracterizado por uma posição desigual entre os sujeitos, intervindo os entes públicos com poderes de autoridade sobre os sujeitos privados). O problema do primeiro critério é que, muitas vezes, o ente público atua na esfera privada como um sujeito privado e despido de prerrogativas de autoridade, assim como os sujeitos privados podem atuar tanto em esferas do direito público quanto no direito eleitoral, penal ou processual. Em relação ao segundo critério, muitas vezes entes jurídicos de direito público podem tomar parte de um contrato em que ambos estão em mesma posição contratual, ao mesmo tempo em que há situações nas quais um sujeito privado exerce prerrogativas de autoridade sobre outro, como no caso do direito de família (relação paterno-filial)." SIMÃO, José Fernando. op. cit., p. 97.
} 
que há muito não se resume a ser a morada apenas das regras e princípios de direito público. $^{42}$

Para Pontes de Miranda, a prevalência dos interesses sociais e coletivos fez com que o Direito Constitucional se tornasse, em um determinado momento histórico "o grande invasor de todos os domínios jurídicos". Nos ensinamentos de Orlando Gomes, para quem esta invasão é impertinente, tem-se que "é nas Constituições que se encontram hoje definidas as proposições diretoras dos mais importantes institutos do direito privado". ${ }^{43}$

Impende destacar que a legislação civilista pretérita era extremamente fechada, ${ }^{44}$ formalista e individualista. ${ }^{45}$ É mister esclarecer que não se vislumbrava um único artigo a respeito dos direitos da personalidade.

Não havia a previsão disseminada das cláusulas gerais, o que gerava por um lado uma segurança jurídica muito grande no sistema e, por outro, no entanto, dificuldades grandes em se aplicar um direito mais justo ao caso concreto e consentâneo com o desejo do corpo social.

No que tange às cláusulas gerais, críticas há que enfatizam o declínio da tripartição de poderes de Montesquieu, porquanto o juiz legislaria no caso concreto, assumindo uma postura de legislador. Assim, se um poder acaba exercendo a função do outro, enfraquecese a divisão de funções estatais. Contudo, agindo dessa forma o Poder Judiciário se torna mais atuante no sentido de completar o direito legislado e, por conseguinte, assume uma postura legislativa inevitável. ${ }^{46}$

\footnotetext{
${ }^{42}$ FACHIN, Luiz Edson. op. cit., p. 149.

${ }^{43}$ Apud CAVALIERI FILHO, Sérgio. Responsabilidade civil constitucional. Revista Forense, Rio de Janeiro, v. 348, p. 197, dez. 1999.

44،"Diversamente da concepção tradicional, que concebia o Direito apenas como o sistema de normas e estas como o seu elemento fundamental, adequadas ao raciocínio lógico-dedutivo, o Direito Civil contemporâneo apresenta-se como um sistema aberto e constituído não só de regras, mas também de princípios que exprimem os valores supremos do sistema jurídico e a ele concedem abertura e flexibilidade". AMARAL, Francisco. A interpretação jurídica segundo o Código Civil. Revista do Advogado, São Paulo, ano 28, n. 98, p. 96, jul. 2008.

${ }^{45}$ De acordo com José de Oliveira Ascensão: a essência do Direito alterou muito desde o reconhecimento do instituto do abuso do direito por doutrinadores franceses. O Direito deixou de ser formalista e individualista, tornando-se um Direito concentrado nas cláusulas gerais, que pretende incorporar valores e valorizar a apreciação do intérprete de acordo com caso concreto. ASCENSÃO, José de Oliveira. A propriedade de bens imóveis na dialética do abuso e da função. In: DELGADO, Mário Luiz; ALVES, Jones Figueiredo (Coords.). Questões controvertidas: direito das coisas. São Paulo: Método, 2008. p. 24. (Série Grandes Temas de Direito Privado, v. 7).

${ }^{46}$ ZIPPELIUS, Reinhold. Teoria geral do Estado. 3. ed. Lisboa: Fundação Calouste Gulbenkian, 1997. p. 416-417.
} 
Entretanto, no último século, o mundo passou por guerras e transformações que desembocaram em um repensar da ciência jurídica, de modo a modificar o objeto precípuo do direito, passando a pessoa a desfrutar de supremacia, o que permitiu uma abertura maior na interpretação do direito em razão da adoção das cláusulas abertas.

Acresça-se que, com o final da $2^{\circ}$ Guerra Mundial, em razão das atrocidades nela cometidas, teve início, em escala mundial, a reconstrução dos direitos humanos, que se espalhou por todos os documentos internacionais e pelos sistemas jurídicos democráticos, tendo sido muito bem assimilado por nossa Lei Suprema em seu artigo $1^{\circ}$, III, sendo considerado, inclusive, como um dos fundamentos da República. Essa dignidade humana estabelece limitações e cria obrigações de fazer para o Estado, com a finalidade de atender às necessidades essenciais da vida do ser humano. Nesse sentido, a dignidade da pessoa humana promove a despatrimonialização do direito e a sua consequente repersonalização, dando ênfase aos valores existenciais e do espírito da pessoa, assim como a promoção e o reconhecimento dos direitos da personalidade, tanto em sua dimensão psíquica como física. $^{47}$

Dessa forma, a pessoa humana passa a ser inserida em uma posição de maior destaque na aplicação do direito, sendo referência constante para a criação da norma jurídica $^{48}$ a ser aplicada no caso concreto, no momento de extrai-la do texto normativo. ${ }^{49}$

Nesse cenário, a tutela do indivíduo influenciou vários institutos jurídicos, entre eles o referente à responsabilidade civil, cujo objetivo máximo é o de reconstruir uma situação jurídica desfigurada pela prática, na maioria das vezes, de um ato ilícito que lesiona a esfera de direitos de uma pessoa.

\footnotetext{
${ }^{47}$ BARROSO, Luís Roberto. op. cit., p. 232-233.

${ }^{48}$ Paulo Ricardo Schier aduz que: "o Direito, como se sabe, também é um fenômeno lingüístico (mesmo para o neoconstitucionalismo). O Direito manifesta-se também através da linguagem. Ao buscar regular as condutas, a linguagem do Direito transmuta-se em enunciados escritos. Estes enunciados é que podem manifestar-se, após a interpretação diante de casos concretos, com conteúdo de regra ou de princípio. Logo, reafirma-se, regras e princípios substanciam o conteúdo normativo de enunciados. E são os enunciados, interpretados a partir da realidade (caso concreto), repise-se, que substanciam o ponto de partida para a criação da norma". SCHIER, Paulo Ricardo. Novos desafios da filtragem constitucional no momento do neoconstitucionalismo. In: SARMENTO, Daniel Antonio de Moraes; SOUZA NETO, Cláudio Pereira (Orgs.). A constitucionalização do direito: fundamentos teóricos e aplicações especificas. Rio de Janeiro: Lumern Júris, 2007. p. 199-200.

49"Nuestra tradición jurídica muestra una división tajante entre la norma y su aplicación, siendo concebidos como dos actos separados emanados del legislador y del Juez respectivamente. Actos disímiles, producidos por sujetos distintos, y com objetos dispares". LORENZETTI, Ricardo. La discrecionalidad del Juez em el marco de la legislación. Revista de la Facultad de Derecho de la Pontifícia Universidad Católica del Peru, Lima, n. 55, p. 162, dic. 2002.
} 
Com efeito, Maria Cecília Bodin de Moraes leciona que a responsabilidade civil baseia-se nos princípios da dignidade da pessoa humana, da solidariedade social, insculpido no art. $3^{\circ}, \mathrm{I}$, da $\mathrm{CF} / 88$ e no princípio da isonomia. ${ }^{50}$

Destarte, a vítima de um ato ilícito assume uma posição privilegiada no contexto da responsabilidade civil, posto que a ciência civilística vislumbrou uma preocupação maior em deixá-la indene, provendo mecanismos de facilitação da sua indenização, enfraquecendo os rigores do ônus da prova e estabelecendo hipóteses de ressarcimento por responsabilidade objetiva.

A releitura do direito civil, a partir da incidência de princípios de nossa Carta Magna, culminou com a objetivação da responsabilidade civil. Ela traduz a evolução da ideologia do modelo individual-liberal de responsabilização do Code Napoleón e do CC/1916, para o denominado modelo solidarista, fundamentado na nossa Lei Suprema que impõe uma atenção e um cuidado maior em relação à vítima. $\mathrm{O}$ foco de análise é o interesse do lesado e não mais se ao autor do dano deva ser imposta a obrigação de indenizar. Isso significa uma vinculação maior do instituto da responsabilidade civil aos preceitos constitucionais da solidariedade, igualdade e dignidade. ${ }^{51}$

Hominum causa omne ius contitutum (Codex Hermogenianus, D. 1.5.2), ou seja, todo o direito existe por causa dos homens, devendo ser aplicado com objetivo de realizar valores, sendo o mais importante o da pessoa humana. Além disso, a ordem jurídica deve sempre se pautar na implementação deles. Vale dizer que o valor da pessoa humana é a razão de existir do próprio direito. ${ }^{52}$

O princípio da dignidade da pessoa humana, previsto em nossa Constituição Federal, ocasionou no sistema da responsabilidade civil a ampliação da tutela da pessoa da vítima em si considerada, em detrimento do escopo precedente da punição ao autor do dano. Essa evolução gerou dois efeitos: um sensível aumento da hipótese de danos

\footnotetext{
${ }^{50}$ MORAES, Maria Celina Bodin de. A constitucionalização do direito civil e seus efeitos sobre a responsabilidade civil. In: SARMENTO, Daniel Antonio de Moraes; SOUZA NETO, Cláudio Pereira (Orgs.). A constitucionalização do direito: fundamentos teóricos e aplicações especificas. Rio de Janeiro: Lumern Júris, 2007. p. 438-440.

${ }^{51}$ Id. Ibid., p. 449.

${ }^{52}$ GRECO FILHO, Vicente. Manual de processo penal. 7. ed. São Paulo: Saraiva, 2009. p. 11.
} 
passíveis de serem indenizados e a supressão da função moralizadora, antigamente reconhecida como um dos elementos mais importantes do instituto. ${ }^{53}$

É apropriado esclarecer que o princípio da dignidade da pessoa humana ${ }^{54}$ se irradia por todo o sistema jurídico, influenciando o modo de se aplicar o direito em todos os seus setores, uma vez que é fundamento do Estado Democrático de Direito.

Em se tratando do princípio da dignidade humana, assevera Antonio Junqueira de Azevedo que a utilização da expressão dignidade da pessoa humana é algo recente no mundo jurídico. Esse princípio jurídico fundamenta-se no imperativo peremptório da intangibilidade da vida humana e promove o surgimento em sequência hierárquica dos seguintes preceitos: 1 - respeito à integridade da pessoa humana em suas várias expressões; 2 - existência de um mínimo existencial para o desenvolvimento da vida; 3 liberdade e convivência igualitária, em sociedade, como fatores mínimos de observância pelo sistema. $^{55}$

No que tange ao princípio da solidariedade, a sua expressão maior, no instituto da responsabilidade civil, encontra-se na previsão pelo sistema da responsabilidade objetiva, que tem como finalidade precípua facilitar a indenização por parte daqueles que sofreram prejuízo.

Reconhece-se que, ao longo do tempo, não obstante, o dever de solidariedade social, base constitucional da responsabilidade civil objetiva, predominará e será aceita a amplitude de sua aplicação a ponto de ser ressarcido todo e qualquer dano injustamente produzido à pessoa, desde que presente o nexo de causalidade com a conduta desenvolvida, havendo ou não perigo. ${ }^{56}$

"O fundamento ético-jurídico da responsabilidade objetiva deve ser buscado na concepção solidarista, fundada na Constituição de 1988, de proteção dos direitos de qualquer pessoa injustamente lesada, fazendo-se

\footnotetext{
${ }^{53}$ MORAES, Maria Celina Bodin de. A constitucionalização do direito civil e seus efeitos sobre a responsabilidade civil, cit., p.439.

${ }^{54}$ Para Ana Paula de Barcellos: "a meta central das Constituições modernas e da Carta de 1988, em particular, pode ser resumida, como já exposto, na promoção do bem estar do homem, cujo ponto de partida está em assegurar as condições de sua própria dignidade, que inclui, além da proteção dos direitos individuais, condições mínimas de existência”. BARCELLOS, Ana Paula de. A eficácia jurídica dos princípios constitucionais. Rio de Janeiro: Renovar, 2002. p. 246.

${ }^{55}$ AZEVEDO, Antonio Junqueira de. A caracterização jurídica da dignidade da pessoa humana. RTDC: revista trimestral de direito civil, Rio de Janeiro, v. 2, n. 9, p. 3-24, jan./mar. 2002.

${ }^{56}$ MORAES, Maria Celina Bodin de. A constitucionalização do direito civil e seus efeitos sobre a responsabilidade civil, cit., p. 450.
} 
incidir o seu custo na comunidade, isto é, em quem quer que com o ato danoso esteja vinculado. No modelo solidarista, invertem-se os termos do problema e a responsabilidade subjetiva nada mais é do que uma outra hipótese de imputação de responsabilidade". ${ }^{57}$

As várias citações doutrinárias, aqui colocadas, estão longe de pôr termo, de forma definitiva, às discussões no que tange ao real limite do macro-princípio da dignidade da pessoa humana e a sua aplicação no ordenamento jurídico como um todo.

Ainda, assim, vale dizer que a sua extensão é demasiadamente ampla, sendo fundamento, como exaustivamente já se fez referência, para o instituto da responsabilidade civil, haja vista a finalidade precípua do instituto: preservar os interesses jurídicos da pessoa em todas as suas ramificações, impedindo que as interferências prejudiciais ao patrimônio jurídico das pessoas permaneçam sem a adequada resposta pelo direito, por meio da reconstrução do interesse agredido.

Por fim, insta esclarecer que o princípio da isonomia também é aplicável à responsabilidade civil, permitindo a análise pormenorizada de cada caso de lesão na esfera jurídica do direito da vítima, impedindo a possibilidade de tarifação do dano moral.

Deveras, o tarifamento do dano moral e a sua consequente padronização, independentemente das características peculiares de cada pessoa, lesaria o princípio da igualdade, porquanto a essência desse preceito constitucional preconiza a necessidade de tratar igualmente os iguais e desigualmente os desiguais na justa medida de suas desigualdades, assim como já afirmara Ruy Barbosa.

Não por outro motivo que o Superior Tribunal de Justiça editou a súmula de $\mathrm{n}^{\circ} 281$ que assim dispõe: “A indenização por dano moral não está sujeita à tarifação prevista na Lei de Imprensa".

Ainda que consideremos a revogação recente da referida Lei, vale a pena enfatizar o escopo da mencionada súmula de deixar claro que o princípio da igualdade se materializa, também, na impossibilidade de se tratar desiguais de maneira igual, pois se assim se proceder o sistema estaria aumentando as desigualdades.

\footnotetext{
${ }^{57}$ MORAES, Maria Celina Bodin de. op. cit., p. 450.
} 
Cada caso de lesão de direitos da personalidade deve ser avaliado de maneira específica, de forma a se adentrar em suas peculiaridades, uma vez que as pessoas são diferentes entre si e sofrem, em virtude dessa diferença, de maneira específica e diversa as consequências de atos danosos aos seus direitos de personalidade. Conferindo-se somente esse tratamento desigual é que se implementará cabalmente o princípio da isonomia.

\subsection{O jusnaturalismo, o positivismo, o pós-positivismo e as consequências na hermenêutica jurídica}

Durante séculos a filosofia do direito se expressava no jusnaturalismo, tanto o de influência religiosa quanto o jusnaturalismo moderno ou de influência racional. Essa filosofia do direito expressava a idéia de que as pessoas possuem direitos que não precisam necessariamente ser reconhecidos pelo Estado para que tenham força cogente. Há direitos que são inerentes à condição humana, em virtude da idéia universal de justiça. A aplicação do jusnaturalismo mantém-se altamente prestigiada, ainda no final do século XIX, quando entra em decadência com o surgimento do positivismo científico e depois com o positivismo jurídico. ${ }^{58}$

A grande dificuldade dessa teoria era a aplicação em categorias abstratas, subjetivas, que não conferiam segurança aos doutrinadores do direito. Não obstante, nas lições de Luiz Roberto Barroso, houve, no final do século XIX, uma evolução científica e tecnológica muito significativa que objetivava dar racionalidade plena à vida, conferindo objetividade e previsibilidade inclusive ao direito.

O positivismo, ${ }^{59}$ diferentemente do que preconizava o jusnaturalismo, equiparou o direito à norma. Assim, para fugir das categorias abstratas do jusnaturalismo, ficou estabelecido que o direito deveria ser considerado apenas naquilo que estivesse previsto na norma.

\footnotetext{
${ }^{58}$ BARROSO, Luís Roberto. op. cit., p. 208.

${ }^{59}$ Ronald Dworkin afirma que: "Os positivistas acreditam que as proposições jurídicas são, na realidade, totalmente descritivas: elas são de fato fragmentos da história. Uma proposição jurídica, na visão deles, é verdadeira somente no caso de ocorrer algum evento como a elaboração de leis, do contrário não". DWORKIN, Ronald. O direito como interpretação. In: TEIXEIRA, Anderson Vichinkeski; OLIVEIRA, Elton Somensi de (Orgs.). Correntes contemporâneas do pensamento jurídico. Barueri/SP: Manole, 2010. p. 14.
} 
Essa ideologia empolgou a filosofia do direito durante toda a primeira metade do século XX, com a idéia de que o Direito seria apenas a norma, atribuindo segurança e previsibilidade ao sistema jurídico que deixou de trabalhar apenas com categorias abstratas. Vale dizer: o positivismo jurídico realizou uma profunda cisão entre o direito, o reino do dever ser prescrito pela norma e todos os outros ramos do conhecimento humano, tais como a filosofia, a ética, a justiça, de acordo com Luís Roberto Barroso.

Registre-se que o positivismo ${ }^{60}$ deixou evidenciado que o direito não se confundiria com qualquer outra ciência humana. O Direito teria por objeto apenas o estudo da norma jurídica, deixando para outras ciências o estudo da legitimidade, da justiça e da ética.

Com esse pensamento, conforme leciona Luís Roberto Barroso, fundamentou-se o Direito até o final da $2^{\mathrm{a}}$ Guerra Mundial, quando o mundo descobriu que o direito nem sempre é um instrumento voltado para trazer paz social e felicidade para as pessoas. A humanidade percebeu que o nazismo, na Alemanha, e o fascismo, na Itália, haviam se implantado em nome da lei e sobre a proteção da Legalidade, de forma que todas as atrocidades cometidas nesse período repugnante fundamentaram-se no cumprimento da norma jurídica. ${ }^{61}$

Por tudo e em tudo, o que restou de forma evidente, a partir dessas experiências históricas catastróficas foi o seguinte: a lei fundamentada pura e simplesmente no positivismo, $^{62}$ podia também ser instrumento da barbárie e de injustiças, provocando o repensar desse modelo, então predominante de filosofia do direito, pois a lei e o direito se

\footnotetext{
60، A tese da separação conceitual entre Direito e moral é um elemento caracterizante do positivismo jurídico chamado metodológico, ou seja, aquele modo de ver segundo o qual o Direito pode ser identificado e descrito em sede científica sem valorações morais". GUASTINI, Ricardo. Os princípios constitucionais como fonte de perplexidade. In: TEIXEIRA, Anderson Vichinkeski; OLIVEIRA, Elton Somensi de (Orgs.). Correntes contemporâneas do pensamento jurídico. Barueri/SP: Manole, 2010. p. 57.

Norberto Bobbio assevera que "o significado histórico da obra Kelsiana está ligado à análise estrutural do direito como ordenamento normativo específico, cuja especificidade consiste, precisamente, não nos conteúdos normativos, mas no modo pelo qual as normas estão unidas umas às outras no sistema". BOBBIO, Norberto. Da estrutura à função: novos estudos de teoria do direito. Tradução de Daniela Beccaccia Versiani, revisão de técnica de Orlando Seixas Bechara, Renata Nagamine. Barueri/SP: Manole, 2007. p. 204-205.

${ }^{61}$ BARROSO, Luís Roberto. op. cit., p. 208.

${ }^{62 ، V i v e u-s e, ~ n o ~ D i r e i t o, ~ p o r ~ l o n g o s ~ e ~ l o n g o s ~ a n o s, ~ s o b ~ o ~ q u a r t o ~ e s c u r o ~ e ~ e m p o e i r a d o ~ d o ~ p o s i t i v i s m o ~ j u r i ́ d i c o . ~}$ Sob a ditadura dos esquemas lógico-subsuntivos de interpretação, da separação quase absoluta entre direito e moral, da idéia do juiz neutro e passivo, da redução do direito a enunciados lingüísticos, da repulsa aos fatos e à vida em relação a tudo que se dissesse jurídico, da separação metodológica e cognitiva entre sujeito e objeto de interpretação, da prevalência sempre inafastável das opções do legislador em detrimento das opções da constituição e da criatividade hermenêutica do juiz, da negação de normatividade aos princípios e, assim, em grande parte, à própria Constituição”. SCHIER, Paulo Ricardo. op. cit., p. 199-200.
} 
confundiam. Nessa fase de compreensão do direito vigorava a letra "fria" da lei, sem a possibilidade, consequentemente, de discussões acerca da justiça da norma ou da sua conformidade com a tábua axiológica da sociedade receptora daquele ordenamento jurídico em vigor. ${ }^{63}$

Deveras, esses equívocos levaram os juristas europeus a concluírem que o positivismo Kelsiano não refletiria a melhor forma de expressar a filosofia do direito, porquanto a sua teoria pura, ${ }^{64}$ como mencionado, constituiu embasamento para justificar perseguições e outras violências praticadas contra os judeus e outras minorias étnicas.

Como é sabido e consabido, o formalismo da teoria pura do direito não abre espaço para discussões em torno do conteúdo da norma. Nessa linha, se a norma fosse válida deveria ser aplicada sem questionamentos, ainda que fosse considerada injusta ou até mesmo absurda. É curial esclarecer que foi essa a linha de defesa usada pelos subordinados de Hitler, no transcorrer de seus julgamentos perante o Tribunal de Nuremberg.

De fato, os seus advogados alegaram que os generais de Hitler apenas cumpriam a lei e, por conseguinte, não poderiam ser responsabilizados pelos delitos praticados em detrimento da humanidade. Ou seja, uma vez que a lei determinava o cometimento de todos aqueles atos teratológicos, ocorridos durante a Segunda Guerra Mundial, os executores de seus comandos agiam, segundo suas defesas, no exercício regular de um direito, o que legitimava suas condutas.

Após essas constatações, iniciou-se um processo histórico revolucionário de elaborações teóricas e filosóficas que redundaram no pós-positivismo, ${ }^{65}$ que basicamente

\footnotetext{
${ }^{63}$ PORTELA, Jorge Guillermo. Los principios jurídicos y el neoconstitucionalismo. Díkaion: revista de fundamentación jurídica, Chia, Bogotá, año 23, n. 18, p. 42, dic. 2009.

64“Nos anos do pós-guerra, ao positivismo jurídico, acusado de conivência com as ditaduras, fora contraposto o jusnaturalismo. Na literatura jurídica daqueles anos, os temas mais freqüentes eram sem dúvida a crise do positivismo jurídico e o renascimento do jusnaturalismo”. BOBBIO, Norberto. op. cit., p. XXXIII, prefácio de Mario Losano.

${ }^{65}$ Ricardo Guastini denomina esse pós-positivismo de juspositivismo ou positivismo soft, asseverando, criticamente, que os seus partidários advogam a idéia de que o Direito não pode sempre ser identificado sem a apreciação de valores morais. Um grande número de constituições contemporâneas possuem princípios que invocam esses valores (como solidariedade, justiça, igualdade, dignidade, entre outros). Destarte, os princípios constitucionais os incorporam, trazendo para o sistema jurídico a apreciação da observância dos valores morais na aplicação da norma. GUASTINI, Ricardo. op. cit., p. 57-58. Luís Roberto Barroso ensina que: “A superação histórica do jusnaturalismo e o fracasso político do positivismo abriram caminho para um conjunto amplo e ainda inacabado de reflexões acerca do Direito, sua função social e sua interpretação. O pós-positivismo busca ir além da legalidade estrita, mas não despreza o direito posto; procura empreender uma leitura moral do Direito, mas sem recorrer a categorias metafísicas. A interpretação e aplicação do ordenamento jurídico hão de ser inspiradas por uma teoria de justiça, mas não
} 
preconiza que o direito não é apenas aquilo que está escrito no texto normativo. ${ }^{66}$ Há valores implícitos e explícitos compartilhados pelo grupo social que também integram o direito. É mister esclarecer que o pós-positivismo ${ }^{67}$ não representou uma volta ao jusnaturalismo, mas sim, fazendo coro com Luís Roberto Barroso, o pós-positivismo representou, em um primeiro momento, o reconhecimento de valores sociais que deveriam fazer parte da interpretação jurídica. Assim, a dignidade da pessoa humana, ${ }^{68}$ a igualdade, a integridade física e outros muitos direitos mesmo quando não positivados integram a ordem jurídica e devem ser interpretados e aplicados pelos operadores do direito.

Vale dizer: o pós-positivismo identifica que há valores difundidos e reconhecidos pela sociedade que devem ser reconhecidos pelo intérprete, mesmo quando não estejam positivados no ordenamento jurídico. A interpretação jurídica não pode mais prescindir

podem comportar voluntarismos e personalismos, sobretudo os judiciais. No conjunto de idéias ricas e heterogêneas que procuram abrigo neste paradigma em construção incluem-se a atribuição de normatividade aos princípios e a definição de suas relações com valores e regras; a reabilitação da razão prática e da argumentação jurídica; a formação de uma nova hermenêutica constitucional; e o desenvolvimento de uma teoria dos direitos fundamentais edificada sobre o fundamento da dignidade humana. Nesse ambiente, promove-se uma reaproximação entre o direito e a filosofia". BARROSO, Luís Roberto. op. cit., p. 208.

${ }^{66}$ Luiz Guilherme Marinoni leciona que: "Se a lei passa a se subordinar aos princípios constitucionais de justiça e aos direitos fundamentais, a tarefa da doutrina deixa de ser a de simplesmente descrever a lei. Cabe agora ao jurista, seja qual for a área da sua especialidade, em primeiro lugar compreender à luz dos princípios constitucionais e dos direitos fundamentais. Essa compreensão crítica já é uma tarefa de concretização, pois a lei não é mais objeto, porém componente que vai levar à construção de uma nova norma, vista não como texto legal, mas sim como o significado da sua interpretação e, nesse sentido, como um novo ou outro objeto. A obrigação do jurista não é mais apenas a de revelar as palavras da lei, mas sim a de projetar uma imagem, corrigindo-a e adequando-a aos princípios da justiça e aos direitos fundamentais". MARINONI, Luiz Guilherme. Curso de processo civil: teoria geral do processo. São Paulo: Ed. Revista dos Tribunais, 2006. v. 1, p. 45.

${ }^{67}$ É curial esclarecer que existem autores constitucionalistas com visão oposta e, conseguintemente, defendem a inexistência deste mencionado pós-positivismo ou neoconstitucionalismo. Carlos Bastide Horbach, por exemplo, em artigo publicado em um livro em homenagem a Jorge Miranda, critica esse posicionamento a respeito da real existência desta nova maneira de interpretação constitucional, concluindo, após comparar as lições de Carlos Maximiliano em comentários à Constituição de 1891 com as idéias do pós-positivismo, que nada há de novo, e que estas idéias defendidas pelos neoconstitucionalistas já eram divulgadas pelo referido autor de há muito tempo. HORBACH, Carlos Bastilde. A nova roupa do direito constitucional: neoconstitucionalismo, pós-positivismo e outros modismos. In: ROCHA, Maria Elizabeth Guimarães Teixeira; PFLUG, Samantha Ribeira Meyer. Lições de direito constitucional em homenagem ao Professor Jorge Miranda. Rio de Janeiro: Forense, 2008. p. 294-298.

${ }^{68}$ De acordo com Ingo Wolfgang Sarlet: “...quanto ao fato de que em princípio, nenhuma restrição de direito fundamental poderá ser desproporcional e/ou afetar o núcleo essencial do direito objeto da restrição. É justamente neste contexto que o princípio da dignidade da pessoa humana passa a ocupar lugar de destaque, notadamente pelo fato de que, ao menos para alguns, o conteúdo em dignidade da pessoa humana acaba por ser identificado como constituindo o núcleo essencial dos direitos fundamentais, ou pela circunstância de mesmo não aceita tal identificação, se considerar que pelo menos (e sempre) o conteúdo em dignidade da pessoa em cada direito fundamental encontra-se imune a restrições". SARLET, Ingo Wolfgang. Dignidade da pessoa humana e direitos fundamentais. 4. ed. rev. atual. Porto Alegre: Livr. do Advogado, 2006. p. 119. 
desse elemento axiológico, sob pena de aplicar-se o direito sem levar em consideração pressupostos de validade da norma. ${ }^{69}$

Com efeito, o ordenamento jurídico necessita de elementos que vão muito além da simples leitura do texto normativo, porquanto o direito é um sistema que sofre ingerência de diversos elementos que dão vida e permitem o seu progresso com a finalidade de atingir melhor os seus objetivos. ${ }^{70}$

Insta ressaltar que o direito não é expresso apenas pela norma, posto que se deva considerar que o direito se traduz de forma melhor pela idéia de sistema, sendo sistema de $2^{\mathrm{a}}$ ordem, uma vez que é um instrumento posto à disposição da sociedade para evitar e solucionar conflitos. ${ }^{71}$

O Direito é considerado um sistema. Compreendido esse termo (sistema) no domínio da sistêmica, vale dizer, na medida em que o Direito idealizado como norma possui caracterização piramidal e estática, com a Carta Magna no cume e a legislação ordinária abaixo, ao se referir ao "sistema", procura-se acrescentar uma aparência dinâmica em que "sistema" é compreendido como um plexo de elementos que interagem e evoluem de maneira relativamente harmônica, como os sistemas solar na Astronomia, ou as células na ciência biológica. Os elementos do sistema jurídico são, (i) além das normas as quais necessitam ininterruptamente de interpretação, (ii) as instituições jurídicas, como as Assembléias, os Tribunais e os Parlamentos; (iii) os componentes do estamento jurídico, como Juízes, Promotores e Advogados; (iv) a Doutrina; e (v) a jurisprudência. Promotores

\footnotetext{
69"Por isso, nos dias atuais, ordenamento jurídico e ordenamento escrito são duas expressões que já não podem ser sinonimizadas. De fato, considerando a defasagem existente entre o futuro projetado pelo legislador e aquele que efetivamente se concretiza, a regra puramente positivista torna-se incapaz de irradiar toda a carga normativa de que uma coletividade necessita para se organizar de foram efetiva. Destarte, em função de tal deficiência, tem-se que, para além de textos legais formalmente declinados, amiúde, o Direito também se vê obrigado a valer-se de disposições não escritas para exercer o seu encargo etiológico de reger a vida em coletividade”. FARO, Frederico Kastrup. Boa-fé objetiva e dever de cooperação: uma análise sob as óticas do exercício da autonomia privada e da execução do contrato. RTDC, Rio de Janeiro, ano 10, v. 38, abr./jun. 2009. p. 5.

${ }^{70 ،}$ A despeito da indiscutível diferença entre o direito e a moral, das finalidades díspares das regras normativas da lei e dos preceitos morais, existe, sem dúvida, uma indiscutível penetração da moral no direito, uma aplicação incomensurável de preceitos morais nas soluções dos problemas jurídicos. A regra jurídica não fornece, muitas vezes, satisfatoriamente, a solução dos problemas jurídicos que os fatos impõem, em virtude da sua rigidez, da ausência de uma certa mobilidade, que possa oferecer ao intérprete a oportunidade de dar-lhe um sentido e uma amplitude indispensáveis à solução do caso em debate. Daí a necessidade, para o intérprete, de recorrer à lei moral, a fim de reforçar, atenuar ou esclarecer a regra jurídica”. LIMA, Alvino. A fraude no direito civil. São Paulo: Saraiva, 1965. p. 7.

${ }^{71}$ AZEVEDO, Antonio Junqueira de. O direito ontem e hoje: crítica ao neopositivismo constitucional e à insuficiência dos direitos humanos. Revista do Advogado, São Paulo, ano 28, n. 99, p. 12-13, set. 2008.
} 
e Advogados, verbi gratia, são elementos de input uma vez que põem as divergências para dentro do ordenamento jurídico com o fim de obter resoluções. Os juízes por sua vez, são órgãos de output, porquanto buscam resolver os impasses da vida em sociedade. ${ }^{72}$

O Direito se amálgama à vida social com essa idéia de sistema de $2^{\mathrm{a}}$ ordem e começa a se justificar não apenas por meio da lei do maior número, porém, através da argumentação daquilo que é socialmente útil, conferindo maior legitimidade à Lei Suprema assim como às leis em geral. ${ }^{73}$

Nessa linha de evolução da ciência jurídica, como já se fez referência alhures, a lei não pode mais ser vista como sinônimo do direito. A lei direciona para os possíveis e razoáveis caminhos a serem seguidos pelo hermeneuta a fim de obter o melhor resultado na interpretação do texto normativo. Entretanto, indubitavelmente, a boa e justa implementação do texto jurídico dependerá da sensibilidade do intérprete em considerar os valores fundamentais incorporados pela sociedade e não retirar do texto da lei a sua regra literal desprovida da tábua axiológica.

É mister registrar que os nossos tribunais, em inúmeras oportunidades, adotaram a filosofia escorada no pós-positivismo, sendo que há julgados que expressamente a ele se referem. ${ }^{74}$

Assim, a melhor interpretação do direito, em nosso sentir, e, mais especificamente no que tange ao estudo objeto da presente dissertação, deve utilizar sempre elementos axiológicos que permitam atingir o bem comum e a segurança. Vale a pena mencionar que, valores $^{75}$ como a primazia do interesse da vítima, a máxima reparação do dano e a solidariedade social, devem ser sempre o ponto de partida e os escopos primordiais do intérprete da norma, quando laboram com o instituto da responsabilidade civil.

\footnotetext{
${ }^{72}$ AZEVEDO, Antonio Junqueira de. op. cit., p. 13.

${ }^{73}$ Id.; loc., cit.

${ }^{74}$ Neste sentido, o STJ já se manifestou: “A Constituição da República Federativa do Brasil, de índole póspositivista e fundamento de todo o ordenamento jurídico, expressa como vontade popular que a República Federativa do Brasil, formada pela união indissolúvel do Estado, Municípios e do Distrito Federal, constitui-se em Estado Democrático de Direito e tem como um dos seus fundamentos a dignidade da pessoa humana como instrumento realizador de seu ideário de construção de uma sociedade justa e solidária". (STJ, Resp. 802.435, Rel. Min. Luiz Fux, $1^{\text {a }}$ T.. j. 19/10/06, DJ 30/10/06).

${ }^{75}$ Paulo Luiz Netto Lobo aduz que nas várias alusões da Constituição com relação ao tema da responsabilidade civil, a nossa Carta Magna tem como objetivo afirmar três valores que são a marca da responsabilidade civil dos dias atuais: a primazia do interesse da vítima, a máxima reparação do dano e a solidariedade social. LÔBO, Paulo Luiz Netto. Teoria geral das obrigações. São Paulo: Saraiva, 2005. p. 13-15.
} 
O jurista não pode ser um conservador de antigas fórmulas em desuso, como se fosse um conservador de um museu de antiguidades: é um intérprete dos tempos vigilante e vivo, que compreende as exigências humanas, traduzindo-as em fórmulas adequadas de convivência ordenada. ${ }^{76}$

O direito precisa evoluir no sentido de conferir a todos o gozo de liberdade, segurança, bem comum, igualdade e justiça que são, segundo Francisco Amaral, ${ }^{77}$ os valores que se constituem o fundamento do sistema jurídico. Este último valor mencionado é traduzido pela célebre frase: dar a cada um o que é seu.

Nessa linha de entendimento, pode-se chegar à ilação de que não é possível extrair a norma do texto normativo, ${ }^{78}$ sem a avaliação, pelo intérprete, verificando, sempre, se os valores fundamentais do direito estão sendo observados. Não se pode olvidar que o positivismo, que predominou durante um bom tempo e fracassou, impedia o estudo do conteúdo da norma em seu sentido axiológico, afastando o direito, muitas vezes, do alcance de seus fins últimos, quais sejam, o de estabilização e pacificação da vida social e a promoção da justiça.

É mister considerar que são os princípios $^{79}$ jurídicos que permitem a entrada no sistema jurídico dos valores que devem ser utilizados na interpretação da norma jurídica. ${ }^{80}$

A leitura simplista dos artigos, previstos no Código Civil e aqui já mencionados, que tratam da responsabilidade por fato de terceiro, pode levar à conclusão de que a ideia que se defende, neste texto, é desprovida de fundamentação jurídica sólida.

\footnotetext{
${ }^{76}$ CALAMANDREI, Piero. Direito processual civil. Campinas/SP: Bookseller, 1999. v. 3, p. 192.

${ }^{77}$ LISBOA, Roberto Senise. Manual de direito civil. 3. ed. São Paulo: Ed. Revista dos Tribunais, 2003. v. 1, p. 42.

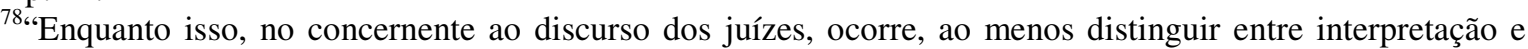
aplicação. Interpretam-se textos normativos, aplicam-se normas (ou, se assim se prefira dizer, textos normativos interpretados. Interpretar é decidir o significado de um texto normativo de modo a encontrar uma ou mais normas. Aplicar as normas de tal modo encontradas é usá-las para resolver concretas controvérsias". GUASTINI, Ricardo. op. cit., p. 51.

${ }^{79}$ Ricardo Guastini advoga que a aplicação da regra jurídica impõe a operação de um raciocínio dedutivo para extrair a norma individual. Por outro lado, a implementação de um princípio significa, aprioristicamente, a sua concretização, utilizando-o como fundamento para a elaboração de uma regra não expressa, sendo suscetível de aplicá-la no primeiro sentido da palavra. GUASTINI, Ricardo. op. cit., p. 51. Nas lições de Ricardo Luis Lorenzetti "os princípios são normas que recepcionam valores, como tais não podem ser mais do que aspirações, cujo grau de concreção varia segundo os sistemas jurídicos, os períodos históricos e a relação com as regras”. LORENZETTI, Ricardo. Fundamentos do direito privado. São Paulo: Ed. Revista dos Tribunais, 1998. p. 317.

${ }^{80}$ BARROSO, Luís Roberto. Diferentes mas iguais: o reconhecimento das relações homoafetivas no Brasil. In: ROCHA, Maria Elizabeth Guimarães Teixeira; PFLUG, Samantha Ribeira Meyer (Coords.). Lições de direito constitucional em homenagem ao Professor Jorge Miranda. Rio de Janeiro: Forense, 2008. p. 129.
} 
Não obstante, se analisarmos os argumentos trazidos, mormente no que se refere à aplicação na análise do texto normativo dos valores jurídicos fundamentais, assim como a imperiosa necessidade de se dar uma resposta satisfatória à vítima de um ato ilícito, é possível chegar-se a lugares mais consentâneos com os anseios sociais.

Para Francisco Amaral, a interpretação jurídica não se cinge a uma simples atividade declaratória, mas a um processo constitutivo do Direito em que as decisões são obtidas. As teorias de ontem estão superadas (normativismo, realismo, jusnaturalismo), nas quais os fatos, valores e normas se expressavam em forma de realidades pré-constituídas. A norma era o ponto principal da iniciativa dessa atividade de raciocínio jurídico e a aplicação dela advinha do pensamento jurídico orientado para esta finalidade. Hoje, a teoria parte do caso concreto e não mais da norma, sendo que os princípios são o alicerce do raciocínio, e o pensamento jurídico é a "razão prática que realiza o Direito por meio de uma interpretação jurídica criativo-normativa". ${ }^{81}$

Peter Harbele advoga que "interpretação é um processo aberto. Não é, pois, um processo de passiva submissão, nem se confunde com a recepção de uma ordem. A interpretação conhece possibilidades e alternativas diversas". ${ }^{82}$

O sistema da legalidade não impõe que o juiz seja um porta-voz inanimado da lei, ou seja, o famoso "bouche de la loi", da forma pretendida por Montesquieu. Impende destacar que, por mais precisa que possa parecer a lei, sempre ao seu aplicador deve ser deferido um espaço de averiguação e de movimentação, no qual encontre a resposta mais consentânea com a sua consciência do que com a lei propriamente dita. ${ }^{83}$

Não se pode olvidar, neste momento, que é direito fundamental individual a garantia da indenização por danos materiais e morais, de acordo com o previsto no art. $5^{\circ}$, $\mathrm{X}$, da $\mathrm{CF} / 88$. É imperioso reconhecer, também, que o direito constitucional evoluiu suficientemente a ponto de reconhecer que os direitos fundamentais também se aplicam às relações privadas. Decerto, a doutrina já se manifesta dessa maneira, aludindo que o Estado Democrático de Direito é aquele comprometido com a tutela e implementação dos direitos fundamentais das pessoas, prevendo mecanismos eficazes para que as infrações a essa

\footnotetext{
${ }^{81}$ AMARAL, Francisco. op. cit., p. 96-97.

${ }^{82}$ HARBELE, Peter. Hermenêutica constitucional: a sociedade aberta dos intérpretes da Constituição: contribuição para a interpretação pluralista e "procedimental" da Constituição. Tradução de Gilmar Ferreira Mendes. Porto Alegre: Sergio Antonio Fabris Editor, 2002. p. 30.

${ }^{83}$ CALAMANDREI, Piero. op. cit., v. 3, p. 200.
} 
categoria de direitos sejam evitadas ou ao menos combatidas, inclusive entre os particulares. Hoje é assente o posicionamento de que tanto o Estado quanto os particulares estão vinculados aos direitos fundamentais. ${ }^{84}$ Trata-se da denominada eficácia horizontal dos direitos fundamentais, que já incorporou inclusive a jurisprudência do STF. ${ }^{85}$

Nesse diapasão, os genitores que convivem com seus filhos capazes e os sustentam, criam um cenário repleto de relações jurídicas que muito se assemelham faticamente àquelas condições traduzidas pela essência do artigo 932 do Código Civil/2002, que trata da responsabilidade civil indireta. Se a teoria tridimensional do direito ${ }^{86}$ preconiza que o mesmo é produto da valoração de fatos e há uma semelhança entre a ideia aqui defendida e a expressão positivada no texto normativo já referido, é curial e razoável que a mesma estrutura jurídica deva ser observada com as mesmas consequências jurídicas. Onde há a mesma razão aplica-se o mesmo direito.

Destarte, se há relação de dependência do filho para com seu genitor, e essa situação, em seus vários desdobramentos, facilita a ocorrência de dano, é mister atribuir a responsabilidade àquele que possui idoneidade patrimonial para ressarcir a vítima que não

\footnotetext{
${ }^{84}$ SARLET, Ingo Wolfgang. Mínimo existencial e direito privado: apontamentos sobre algumas dimensões da possível eficácia dos direitos fundamentais sociais no âmbito das relações jurídico-privadas. In: SARMENTO, Daniel Antonio de Moraes; SOUZA NETO, Cláudio Pereira (Orgs.). A constitucionalização do direito: fundamentos teóricos e aplicações especificas. Rio de Janeiro: Lumern Júris, 2007. p. 339. Neste mesmo sentido: "A grande metanarrativa do direito civil moderno era a fraternidade, hoje é a solidariedade e a realização dos direitos humanos em pleno direito privado". MARQUES, Claudia Lima. Contratos no Código de Defesa do Consumidor. 4. ed. São Paulo: Ed. Revista dos Tribunais, 2002. p. 416.

${ }^{85}$ De acordo com recente decisão de nossa Suprema Corte: "As violações a direitos fundamentais não ocorrem somente no âmbito das relações entre o cidadão e o Estado, mas igualmente nas relações travadas entre pessoas físicas e jurídicas de direito privado. Assim os direitos fundamentais assegurados pela Constituição vinculam diretamente não apenas os poderes públicos, estando direcionados também à proteção dos particulares em face dos poderes privados". (STF, RE 201.819, Rel. Min. Ellen Gracie, Rel. p/ acórdão Min. Gilmar Mendes, j. 11/10/05, DJ 27/10/06).

${ }^{86}$ Miguel Reale nos ensina que: "Desde a sua origem, isto é, desde o aparecimento da norma jurídica, - que é síntese integrante de fatos ordenados segundo distintos valores, - até ao momento final de sua aplicação, o Direito se caracteriza por sua estrutura tridimensional, na qual fatos e valores se dialetizam, isto é, obedecem a um processo dinâmico que aos poucos iremos desvendando. Nós dizemos que esse processo do Direito obedece a uma forma especial de dialética que denominamos "dialética de implicação-polaridade", que não se confunde com a dialética hegeliana ou marxista dos opostos. Esta é, porém, uma questão que só poderá ser melhor esclarecida no âmbito da Filosofia do Direito. Segundo a dialética de implicaçãopolaridade, aplicada à experiência jurídica, o fato e o valor nesta se correlacionam de tal modo que cada um deles se mantém irredutível ao outro (polaridade) mas se exigindo mutuamente (implicação) o que dá origem à estrutura normativa como momento de realização do Direito. Por isso é denominada também "dialética de complementariedade". REALE, Miguel. Lições preliminares de direito. 24. ed. São Paulo: Saraiva, 1998. p. 67.
} 
pode, obviamente, ficar desprovida de resposta estatal. Essa assertiva deve prevalecer até como um meio para que sejam diminuídas as desigualdades sociais. ${ }^{87}$

A máxima necessidade de se indenizar a pessoa que sofreu um dano na esfera jurídica de direitos, foi fundamento para a previsão pelo novo sistema civil da obrigação do incapaz de reparar a lesão, desde que satisfeitos alguns requisitos. Ou seja, de acordo com o art. 928, do novo Código Civil, em uma revolucionária modificação, aquele que ainda não tem a capacidade de entender e de querer pode ser responsabilizado com seu próprio patrimônio pelo ilícito cometido. ${ }^{88}$

É curial reconhecer que o dispositivo acima referido, apesar de seus inúmeros aspectos positivos, mormente pelo fato de não deixar desamparada a vítima de um dano, causou uma alteração na forma de se pensar os requisitos da responsabilidade civil, porquanto retirou de sua estrutura jurídica a necessidade da presença de um elemento implícito, qual seja, a imputabilidade. Senão vejamos.

Como é consabido, são elementos da responsabilidade civil, genericamente e abstraindo-se desta explanação a diferença entre responsabilidade civil subjetiva e objetiva, a conduta voluntária, o dano, e o nexo de causalidade. Não é pertinente acrescentar o ato ilícito entre os seus requisitos, haja vista o fato de que nem sempre é este elemento essencial para a deflagração da obrigação de ressarcir, porque muitas são as circunstâncias em que a ocorrência de um prejuízo por si só acarretará a responsabilidade ainda que tenha ele advindo da prática de um ato em conformidade com o direito.

Ocorre que a conduta voluntária, ${ }^{89}$ preenchida com o necessário discernimento (com exceção dos relativamente incapazes), sempre foi requisito indispensável para o surgimento do dever de reparar danos, não se confundindo, em nossa opinião, de acordo com o sistema jurídico em sua integralidade, com a culpa lato sensu, expressada pela culpa em sentido estrito ou pelo dolo.

\footnotetext{
${ }^{87} \mathrm{CF} / 88$.Art. $3^{\circ}$ Constituem objetivos fundamentais da República Federativa do Brasil;

III- erradicar a pobreza e a marginalização e reduzir as desigualdades regionais sociais e regionais.

${ }^{88}$ Prevê o art. 928 do Código Civil: "O incapaz responde pelos prejuízos que causar, se as pessoas por ele responsáveis não tiverem obrigação de fazê-lo ou não dispuserem de meios suficientes”. Parágrafo único. A indenização prevista neste artigo, que deverá ser equitativa, não terá lugar se privar do necessário o incapaz ou as pessoas que dele dependam".

${ }^{89}$ LISBOA, Roberto Senise. Manual de direito civil: obrigações e responsabilidade civil, cit., v. 2, p. 431.
} 
Assim, em nosso entender, sempre pairou o entendimento de que a voluntariedade era inerente às pessoas providas de discernimento, o que vale dizer que aos incapazes, sempre e como regra, era afastada a possibilidade de indenizar ainda que cometessem ato ilícito, uma vez que havia a presunção absoluta de falta ou redução da capacidade de entender e de querer. É mister esclarecer que essa presunção juris et de iure era atribuída aos absolutamente incapazes e, no que tange aos relativamente incapazes, havia uma relativização ao menor púbere que detinha um tratamento um pouco diferenciado.

Com efeito, não se pode olvidar que o Código Civil de 1916, em seu artigo 156, trazia a possibilidade de se atribuir as consequências da prática de um ilícito ao relativamente incapaz, em razão da idade, tornando-o solidariamente responsável juntamente com seus genitores pelo dano causado a terceiros e obrigando-o, eventualmente, a ressarcir a vítima de um ato seu contrário ao direito. ${ }^{90}$

Destarte, a regra era de que os absoluta e relativamente incapazes não tinham capacidade psíquica de entender o caráter ilícito do ato danoso que porventura praticassem, razão pela qual não lhes era imputada a obrigação de reparar o prejuízo, ressalvado, como já visto, o tratamento conferido ao relativamente incapaz, em razão da idade.

Pois bem, com a inovação trazida pelo atual Código Civil, não acreditamos ser preciso (exato) afirmar que a estrutura jurídica, composta pelos elementos deflagradores da responsabilidade civil, estaria desnaturada com a previsão expressa do dever de ressarcir ao incapaz (o artigo 928, do Código Civil, não diferencia o relativa do absolutamente incapaz). Não, o que ocorreu foi a consagração do mega princípio da dignidade da pessoa humana, no campo da responsabilidade civil, ocasionando uma mitigação no arquétipo desse milenar instituto jurídico, afastando-se a necessidade, em algumas circunstâncias, da aferição da imputabilidade da pessoa para que possa ser obrigada a indenizar o prejuízo causado.

Assim, a doutrina vem lecionando a respeito da subsidiariedade da responsabilidade do incapaz, esclarecendo que ela apenas surgirá caso o representante do autor do ilícito, por alguma razão, não tenha o dever de indenizar ou não tenha patrimônio suficiente para fazê-lo. Vale dizer, primeiro responde ou é chamado a responder o responsável legal com

\footnotetext{
${ }^{90}$ Art. 156. O menor, entre 16 (dezesseis) e 21 (vinte e um) anos, equipara-se ao maior quanto às obrigações resultantes de atos ilícitos, em que for culpado.
} 
seu patrimônio e, caso não seja esse patrimônio suficiente para reparar os danos causados ou não tenha o responsável legal, por qualquer circunstância juridicamente relevante, o dever de ressarcir, será, então, atribuída a obrigação de indenizar equitativamente ao incapaz lesante com seu próprio patrimônio, desde que seja suficiente para tanto. ${ }^{91}$

Ora, se vigora, apesar de suas exceções, o regramento de que o incapaz não tem, perante o sistema jurídico como um todo, discernimento e vontade jurídica suficiente para alterar, extinguir ou criar relações jurídicas e, mesmo assim, o sistema atual alberga a possibilidade de ele ter que tornar indene a esfera jurídica de direitos de terceiros por danos que tenha causado, é razoável e lógico afirmar que há valores maiores no ordenamento que fundamentaram a modificação do protótipo até então dogmático do instituto da responsabilidade civil, permitindo, desta forma, a responsabilização do incapaz.

Sob esse prisma, se o incapaz não sabe, juridicamente afirmando, o que faz e ainda diante da prática de um ato ilícito pode eventualmente ser compelido a pagar com seu próprio patrimônio a lesão perpetrada, pela mesma razão, o genitor que sustenta o seu filho economicamente dependente e foi o protagonista principal da educação dele, também terá o dever de indenizar os prejuízos que seu descendente de primeiro grau cause, caso não tenha ele (seu filho) patrimônio idôneo para tanto. Os princípios da isonomia, da dignidade da pessoa humana e da solidariedade precisam adentrar na interpretação do capítulo atinente à responsabilidade civil, para se extrair uma ilação equilibrada e razoável do sistema.

Dessarte, se evoluímos a ponto de permitir, para salvaguardar os interesses do prejudicado, que o inimputável possa sofrer as consequências jurídicas de seus atos, o genitor, que facilita a ocorrência do dano e teve vários anos para formar o caráter de seu filho e assente na condição de ele apenas estudar sem ter que trabalhar, deve ressarcir os atos prejudiciais que sua criação venha a ocasionar nas condições aqui defendidas.

\footnotetext{
${ }^{91}$ Maria Helena Diniz assim interpreta o dispositivo em debate: "Pessoa incapaz que lesar outrem deverá, tendo recursos econômicos, indenizar, equitativamente, os prejuízos que causou, se o seu responsável não tiver obrigação de arcar com tal ressarcimento (p. ex., não ser o genitor-guardião) ou se não tiver meios suficientes para tanto. Se o lesado não conseguir obter do representante do incapaz o que lhe é devido, por falta de meios financeiros, p. ex., o magistrado poderá condenar o lesante incapaz ao pagamento de uma indenização equitativa. Primeiro responderá o representante do incapaz com seus bens, por ser seu responsável, e o lesante, apesar de incapaz, apenas subsidiariamente perante terceiro, para garantir, em certa medida, a reparação do dano causado.” DINIZ, Maria Helena. op. cit., p. 717.
} 


\section{PERSONALIDADE JURÍDICA E A CAPACIDADE}

\subsection{Personalidade jurídica e capacidade}

Todo direito é elaborado com vistas ao homem, ou seja, hominum causa omne ius constitutum est. (D. 1,5,2 Hermog). Para o ius civile, no Direito Romano, a personalidade jurídica coincidia com o momento do nascimento. Partus nondum editus homo non recte fuisse dicitur, (D. 35,2,9,1 Papin), porquanto antequan edatur, mulieris portio est vel viscerum. (D. 25,4.1.1 Ulp.), ou seja: O feto, nas entranhas maternas, era uma parte da mãe e não uma pessoa que pudesse ter direitos.

No direito pátrio, a personalidade civil da pessoa ${ }^{92}$ começa do nascimento com vida; mas a lei põe a salvo, desde a concepção os direitos do nascituro (art. $2^{\circ}, \mathrm{CC} / 2002$ ). Disso decorre que o homem, pessoa natural, é o sujeito ou a pessoa sem a qual não podem coexistir as relações jurídicas. Impossível, portanto, é a existência de faculdade ou poder sem sujeito.

Emerge claro, do conceito de pessoa a ideia da representação da personalidade por estar intimamente entrosada e ligada a ela, pois exprime a aptidão genérica para adquirir direitos e contrair obrigações. ${ }^{93}$ Muito embora, no direito pátrio, a extensão dos atributos da personalidade a todo o ser humano tenha vigorado em todos os tempos, mesmo na época da escravidão, durante o período clássico do direito romano, tanto o escravo quanto o estrangeiro eram tratados como coisa, desprovidos da faculdade de adquirir e transmitir direitos. Na relação jurídica a que compareciam figuravam sempre como objeto.

Atualmente, o direito reconhece os atributos da personalidade com o sentido geral de universalidade, e o novo Código Civil assim o declara ao afirmar que toda pessoa é capaz de direitos e deveres na ordem civil (art. $1^{\circ}, \mathrm{CC} / 2002$ ), empregada a palavra na acepção de todo ser humano, todo indivíduo pertencente à espécie humana, ao humanum genus, sem qualquer distinção de sexo, idade, condição social ou outra característica. ${ }^{94}$

\footnotetext{
92“"Pessoa é o ser a que se atribuem direitos e obrigações”. BEVILAQUA, Clovis. Teoria geral do direito civil. 2. ed. São Paulo: Livr. Francisco Alves, 1929. p. 80.

${ }^{93}$ GONÇALVES, Cunha. Tratado. Vol. I, p. 29.

${ }^{94}$ PEREIRA, Caio Mário da Silva. Introdução ao direito civil: teoria geral do direito civil. 9. ed. Rio de Janeiro: Forense, 1985. p. 154.
} 
Ao afirmar que o direito é a relação a que se vinculam exclusivamente duas ou mais pessoas entre si e que todo homem tem atributo da personalidade, não se está a afirmar que somente o homem, individualmente considerado, tem aptidão. Isso porque o direito reconhece igualmente personalidade a entidades morais, quais sejam as que se formam de agrupamentos de indivíduos que se associam para a realização de uma finalidade econômica ou social (sociedade e associações), como ocorre com a destinação de um patrimônio para um fim específico (fundações), com autonomia e independência atribuídas às pessoas físicas de seus componentes ou dirigentes. ${ }^{95}$

Ao enfatizar que toda pessoa é capaz de direitos e deveres na ordem civil, o artigo $1^{\text {o }}$ do atual Código Civil deixa evidenciada a ideia de capacidade, intimamente ligada com a de personalidade e de pessoa. Vale dizer: Ser capaz de adquirir direitos e contrair obrigações, ou nas palavras de Washington de Barros Monteiro, "Capacidade é a aptidão para adquirir direitos e exercer, por si ou por outrem, atos da vida civil. O conjunto desses poderes constitui a personalidade que, localizando-se ou concretizando-se num ente, forma a pessoa". 96

Quando a lei menciona a capacidade, referida expressão, como mencionado, reporta-nos ao estudo de outros fenômenos jurídicos extremamente vinculados entre si, quais sejam: personalidade, capacidade de direito e capacidade de fato. "Personalidade é a aptidão, reconhecida pela ordem jurídica a alguém para exercer direitos e contrair obrigações". 97

A capacidade de direito é ligada à personalidade jurídica, porquanto quem detém a primeira, certamente, possui a segunda, ${ }^{98}$ ainda que não possa por si só exercer os atos da vida civil.

De acordo com as palavras de Clóvis Bevilaqua, "cumpre distinguir a personalidade da capacidade, que é a extensão dada aos poderes de ação contidos na personalidade, ou como diz Teixeira de Freitas, o modo de ser geral das pessoas". 99

\footnotetext{
${ }^{95}$ PEREIRA, Caio Mário da Silva. op. cit., p. 154.

${ }^{96}$ MONTEIRO, Washington de Barros. Curso de direito civil: parte geral. 31. ed. São Paulo: Saraiva, 1993. v. 1, p. 57-58.

${ }^{97}$ BEVILAQUA, Clovis. op. cit., p. 80.

${ }^{98}$ RODRIGUES, Silvio. Direito civil: parte geral. 30. ed. São Paulo: Saraiva, 2000. v. 1, p. 37.

${ }^{99}$ BEVILAQUA, Clovis. op. cit., p. 81.
} 
Por outro lado, não se pode olvidar que, no gênero capacidade, é possível encontrar a capacidade de fato, que se expressa pela concessão ao indivíduo da possibilidade da prática de atos da vida civil, ${ }^{100}$ independentemente de representação ou assistência.

Dessa forma, a lei cria mecanismos de proteção ao indivíduo que, por razão biológica ou patológica, aos "olhos" do ordenamento jurídico, não tem discernimento necessário para praticar, por si, atos da vida civil.

Esses mecanismos de proteção são verdadeiras barreiras, que impedem os indivíduos, legalmente qualificados em determinadas situações da vida, de manifestarem sua vontade com a adequada relevância perante o sistema jurídico.

Nesse sentido, surgem as incapacidades ${ }^{101}$ absolutas e relativas, com o escopo de macular atos jurídicos que desatendam as limitações impostas pela lei àquelas pessoas inaptas para praticá-los, de forma que sejam tuteladas ${ }^{102}$ como já se relatou.

O instituto da incapacidade tem como objetivo tutelar aqueles que são portadores de uma deficiência jurídica, sendo que o sistema gradua, ${ }^{103}$ de acordo com as reais necessidades da pessoa, essa espécie de proteção. Assim, para os absolutamente incapazes o ordenamento destina o instituto da representação, haja vista o fato de não possuírem o necessário discernimento para a prática de atos da vida civil. Para os relativamente incapazes, o sistema oferece uma tutela mitigada que se exterioriza por meio da assistência. $^{104}$

Com efeito, nos artigos $3^{\circ}$ e $4^{\circ}$ do Código Civil de 2002, encontramos uma lista de circunstâncias da vida que diminuem ou eliminam o potencial jurídico modificativo da vontade das pessoas ao praticarem qualquer ato jurídico em sentido amplo. ${ }^{105}$

\footnotetext{
${ }^{100}$ MONTEIRO, Washington de Barros. op. cit., v. 1, p. 61.

101،Para todas as situações de incapacidade jurídica o direito reserva solução, por intermédio de institutos civis, colocando a pessoa incapacitada sob a proteção jurídica de alguém que pode lhe salvaguardar os direitos: pais, tutores ou curadores dos incapazes suprem essa deficiência, permitindo que o incapaz possa realizar os atos da vida jurídica em plena igualdade formal de direitos. Por isso se diz que os institutos de ausência, curatela, poder familiar permitem essa solução lógica para a questão jurídica da possibilidade de incapacidade de exercício do sujeito, questão essa que não pode ficar sem resposta”. NERY, Rosa Maria de Andrade. op. cit., p. 279.

${ }^{102}$ RODRIGUES, Silvio. op. cit., v. 1, p. 39.

${ }^{103}$ Id. Ibid., p. 42.

${ }^{104}$ DINIZ, Maria Helena. Curso de direito civil brasileiro. 18. ed., São Paulo: Saraiva, 2002. v. 1, p. 141.

${ }^{105}$ De acordo com José Carlos Moreira Alves, não nasce dos romanos a teoria dos atos jurídicos, uma vez que eram eles juristas práticos que não se preocupavam, na maioria das vezes, com categorias abstratas do direito. O que importava eram os atos que criavam obrigações e os seus fatos. "Cuidaram eles de atos
} 
jurídicos específicos e não da figura genérica de ato jurídico, e as expressões actus e negotium que se encontram em seus textos não têm significado técnico". ALVES, José Carlos Moreira. O novo Código Civil brasileiro e o direito romano: seu exame quanto às principais inovações no tocante ao negócio jurídico. In: FRANCIULLI NETTO, Domingos; MENDES, Gilmar Ferreira; MARTINS FILHO, Ives Granda da Silva (Coords.). O novo Código Civil: estudos em homenagem ao Prof. Miguel Reale. São Paulo: LTr, 2003. p. 116. Impende destacar que o ato jurídico é um fato jurídico humano voluntário, conquanto necessite da manifestação de vontade do sujeito de direito. Fatos jurídico, na lição de Emilio Betti, "são, portanto, aqueles factos a que o direito atribui relevância jurídica, no sentido de mudar as situações, a que correspondem novas qualificações jurídicas". BETTI, Emilio. Teoria geral do negócio jurídico. Coimbra: Coimbra Ed., 1969. t. 1, p. 20.

Para R. Limongi França, ato jurídico "é toda manifestação lícita da vontade, que tenha por fim criar, modificar ou extinguir uma relação de direito. Assevera que a doutrina indica haver diferença entre ato jurídico e negócio jurídico, contudo não há uniformidade. Em sua opinião, no negócio jurídico "depara-se a auto-limitação da vontade, o que não sucede com os atos não negociais”. FRANÇA, Rubens Limongi. Instituições de direito civil. 3. ed. São Paulo: Saraiva, 1994. p. 125.

Nas lições de Sílvio de Salvo Venosa, "atos jurídicos meramente lícitos são os praticados pelo homem sem intenção direta de ocasionar efeitos jurídicos, tais como invenção de um tesouro, plantação em terreno alheio, construção, pintura sobre tela. Todos esses atos podem ocasionar efeitos jurídicos, mas não têm, em si, tal intenção. São eles contemplados pelo art. 185 do atual Código. Esses atos não contêm intuito negocial... Quando existe por parte da pessoa a intenção específica de gerar efeitos jurídicos ao adquirir, resguardar, transferir, modificar ou extinguir direitos, estamos diante do negócio jurídico. Tais atos nosso Código Civil de 1916 denominava atos jurídicos, de acordo com o art. 81; a moderna doutrina prefere denominá-los negócios jurídicos, por ver neles o chamado intuito negocial. Assim serão negócios jurídicos tanto o testamento, que é unilateral, como o contrato, que é bilateral. VENOSA, Sílvio de Salvo. Direito civil: parte geral. 6. ed. São Paulo: Atlas, 2006. v. 1, p. 338.

De acordo com os ensinamentos de Maria Helena Diniz "o ato jurídico em sentido amplo abrange o ato jurídico em sentido estrito e o negócio jurídico. Os atos jurídicos em sentido estrito geram consequências jurídicas previstas em lei e não pelas partes interessadas, não havendo, como ocorre nos negócios jurídicos, regulamentação da autonomia privada, que cria norma para regular interesses das partes (p.ex.: contratos, adoção, testamento, etc)". DINIZ, Maria Helena. Código Civil anotado. 11. ed. São Paulo. Saraiva: 2002. p. 216. Carvalho de Mendonça, ao tratar dos contratos, faz uma análise acerca dos atos jurídicos nos seguintes termos: "O contrato é um acto jurídico em sua mais ampla compreensão. Na base de toda a relação jurídica, deve estar um facto. Facto jurídico é o acontecimento em virtude do qual as relações de direito nascem e terminam, como o nascimento, a morte, etc. Os factos jurídicos dividem-se em factos jurídicos em sentido próprio e em actos jurídicos. Estes são os actos humanos que podem ser voluntários e involuntários. Os actos voluntários são os actos jurídicos por essencia. Todo acto licito, que tenha por fim imediato adquirir, adquirir, conservar, modificar ou extinguir direitos denomina-se acto jurídico. Estes, pois, são os factos jurídicos voluntários, cujo fim e efeito é dar vida a uma relação de direito. Os actos lícitos quando dirigidos directamente à aquisição, modificação, ou extinção de direitos, só produzirão esse efeito em casos em que expressamente o declarar. Ocasiões há bem frisantes em que os actos jurídicos se confundem com os negocios jurídicos. Estes, porém, são sub espécie em a qual a vontade do sujeito tem por escopo e não somente por efeito dar vida a uma relação de direito. O elemento fundamental do acto jurídico é a vontade de quem age". CARVALHO DE MENDONÇA, Manoel Ignácio. Doutrina e prática das obrigações. 2. ed. Rio de Janeiro: Francisco Alves, 1911. v. 2, p. 154-155.

Não obstante, concordamos com o conceito de Marcos Bernardes de Mello para quem no ato jurídico em sentido estrito, a vontade declarada do sujeito já encontra uma conseqüência jurídica que não pode ser alterada pelo declarante, ou seja, todos os efeitos são predeterminados por lei. MELLO, Marcos Bernardes de. Teoria do fato jurídico (plano da existência). 16. ed. São Paulo: Saraiva, 2010. p. 155.

Destarte, entendemos que o ato jurídico em sentido amplo é gênero de que são espécies o ato jurídico em sentido estrito, o negócio jurídico e o ato-fato jurídico. Para nós, a grande diferença entre o ato jurídico em sentido estrito e o negócio jurídico é a possibilidade da parte, neste último ato, acrescentar elementos acidentais, que vão influenciar a eficácia do negócio jurídico. Por outro lado, no ato jurídico em sentido estrito, uma vez que os seus efeitos são pré-ordenados na lei, a parte não pode estipular nada que tenha o condão de mudar os efeitos previamente estabelecidos na lei, por exemplo, inserindo uma cláusula resolutiva no reconhecimento voluntário de filiação. 
Trata-se a incapacidade de uma restrição imposta pela lei ao exercício dos atos da vida civil, devendo ser considerada restritivamente, porquanto o princípio é de que "a capacidade é a regra e a incapacidade a exceção", ${ }^{106}$

$\mathrm{O}$ artigo $3^{\circ}$ expressa que: "são absolutamente incapazes de exercer pessoalmente os atos da vida civil: os menores de dezesseis anos; os que, por enfermidade ou deficiência mental, não tiverem o necessário discernimento para a prática desses atos; os que, mesmo por causa transitória, não puderem exprimir a sua vontade".

Certas situações da vida, vivenciadas pela pessoa absolutamente incapaz, torna-a inapta para praticar por si atos jurídicos em sentido amplo, em virtude da ausência de discernimento. ${ }^{107}$

Também, como já foi referido, a falta de idade mínima ou alguma doença mental podem elidir a capacidade da pessoa de expressar uma vontade com discernimento.

É mister esclarecer, que todas essas situações jurídicas não impossibilitam as pessoas de praticarem atos jurídicos. Ocorre que, para que isso aconteça com validade seus representantes legais deverão praticar o ato em seus nomes, vez que a vontade dos absolutamente incapazes, para o direito, não tem, em regra, a mínima relevância. ${ }^{108}$ Dessa forma, fala-se no instituto da representação. ${ }^{109}$

Não se pode olvidar, outrossim, que os atos praticados pelos absolutamente incapazes são nulos, de acordo com o artigo 166 do Código Civil de $2002 .^{110}$

Como foi mencionado, o artigo $4^{\circ}$, do Código Civil de 2002, trata dos relativamente incapazes, estabelecendo um rol de circunstâncias que a lei entende ensejadoras da redução do discernimento das pessoas que passam pelas situações elencadas.

Aduz o referido artigo: "São incapazes, relativamente a certos atos, ou à maneira de os exercer: os maiores de dezesseis e menores de dezoito anos; os ébrios habituais, os viciados em tóxicos, e os que, por deficiência mental, tenham o discernimento reduzido; os excepcionais sem desenvolvimento mental completo; os pródigos".

\footnotetext{
${ }^{106}$ DINIZ, Maria Helena. Código Civil anotado, cit., p. 12.

${ }^{107}$ RODRIGUES, Silvio. op. cit., v. 1, p. 42.

${ }^{108}$ Id. Ibid., p. 43.

${ }^{109}$ MONTEIRO, Washington de Barros. op. cit., v. 1, p. 61.

${ }^{110}$ GONÇALVES, Carlos Roberto. Direito civil: parte geral. 10. ed. São Paulo: Saraiva, 2003. p. 36.
} 
Em seu parágrafo único, o artigo $4^{\circ}$ preconiza que "A capacidade dos índios será regulada por legislação especial”.

A incapacidade relativa confere uma autonomia mitigada à pessoa, facultando-lhe a prática do ato, necessitando, contudo, da assistência daqueles que o direito encarrega desse mister, como: pais, tutores ou curadores, com o objetivo de aperfeiçoar o ato. ${ }^{111}$

Deveras, a pessoa relativamente incapaz tem discernimento reduzido e, em razão disso, caso pratique atos ou negócios jurídicos desprovidos de assistência serão esses atos considerados anuláveis. ${ }^{112}$

Sobreleva ressaltar que o sistema confere aos maiores de 16 e menores de 18 anos a plena capacidade para a prática de determinados atos, sem tal assistência, como a aceitação de mandato (art. 666 do CC), o testamento pelo maior de 16 anos (art. 1860, parágrafo único do CC) ou a possibilidade de servir como testemunha (art. 228,I do CC). ${ }^{113}$

A principal expressão jurídica de acordo com rol apresentado pelo artigo $4^{\circ} \mathrm{em}$ comento é o "discernimento reduzido". Ou seja, todas aquelas circunstâncias apresentadas expressam a diminuição do discernimento, fator esse que resulta na incapacidade relativa da pessoa, limitando a sua autonomia de vontade.

\subsection{Capacidade e incapacidade dos menores na prática dos atos jurídicos}

Os intérpretes de nosso ordenamento jurídico, mais condicionados e habituados a trabalharem com sistemas fechados, ${ }^{114}$ em virtude de nossa tradição jurídica em que impera o vetor segurança na interpretação, estipularam formas de definir conceitos e consequências jurídicas para institutos do direito que incorporaram essa ideologia. ${ }^{115}$

\footnotetext{
${ }^{111}$ VENOSA, Sílvio de Salvo. op. cit., v. 1, p. 145.

${ }^{112}$ RODRIGUES, Silvio. op. cit., v. 1, p. 44.

${ }^{113}$ MONTEIRO, Washington de Barros. op. cit., v. 1, p. 63.

${ }^{114}$ José de Oliveira Ascensão, em artigo denominado "Cláusulas gerais e segurança jurídica no Código Civil de 2002", assevera que o Código Civil de 1916, diferentemente do atual, era essencialmente taxativo e fechado, dotado de um extremo legalismo. ASCENSÃO, José de Oliveira. Cláusulas gerais e segurança jurídica no Código Civil de 2002. RTDC: revista trimestral de direito civil, Rio de Janeiro, ano 7, v. 28, p. 77, out./dez. 2006.

${ }^{115}$ Arruda Alvim, ao lecionar a respeito das consequências, no ordenamento jurídico, da ideologia do Estado Liberal, aduz que a maneira através da qual a burguesia dominou o século XIX foi precisamente por meio da lei, espraiando a idéia de que não poderia jamais haver interpretação do texto normativo. Demais disso, os textos legais da época, que influenciaram o nosso Código Civil de 1916, eram minuciosos e detalhistas, não deixando margem de apreciação subjetiva ao julgador para que analisasse as peculiaridades do caso
} 
No entanto, a complexidade da vida social, assim como a extensão de nosso país e a dinâmica da vida, em sociedade, impuseram ao legislador a necessidade de modificar a estrutura dos textos normativos, de forma a se utilizar de cláusulas gerais que possibilitam uma análise pormenorizada do caso concreto no momento de aplicação do direito. ${ }^{116}$

Não é mais possível, como outrora, prever as decisões judiciais, porquanto foi conferido ao julgador poderes imensos para fazer a justiça do caso concreto, utilizando-se das referidas cláusulas gerais. ${ }^{117}$

Com relação ao vetor segurança jurídica, muito difundido na codificação anterior, e que foi responsável, em parte, pelas idéias dos extremos, vê-se hoje em dia que o texto normativo encontra-se muito mais aberto e, conseguintemente, menos previsível e seguro. $^{118}$

Surgiram novas maneiras de se interpretar institutos clássicos da ciência do Direito que, em razão de sua evolução, foram perdendo a importância com relação às suas estruturas internas, dando lugar à visão da sua importância perante o ordenamento jurídico,

concreto. ALVIM, Arruda. A função social dos contratos no novo Código Civil. In: SIMPÓSIO SOBRE O NOVO CÓDIGO CIVIL BRASILEIRO. Coordenação Glauber Moreno Talavera; Lamera, Antonio Valdir Úbeda e Nelson Paisini. São Paulo: [s.n.], 2003. p. 87-88.

116، A linguagem que se utiliza o legislador nesse novo Código Civil é uma linguagem permeada por cláusulas gerais, prenhe de conceitos vagos, ou seja, são idéias, núcleos de valores apresentados pelo legislador, mas cujo preenchimento demandará necessariamente que sejam completados pelo juiz à luz das circunstâncias do caso concreto. Os textos contêm grandes diretrizes, mas saber, concretamente, se essas são aplicáveis a um caso concreto, dependerá de serem avaliadas essas diretrizes em interação com as peculiaridades do caso. Ou, por outras palavras, essas diretrizes não trazem, consigo próprias, elementos precisos, nem fronteiras definidas para serem facilmente aplicadas". ALVIM, Arruda. op. cit., p. 96.

${ }^{11}$ Luciano Benetti Timm aduz que a legislação de um Estado Social se identifica por um grau de abstração mais acentuado em suas normas jurídicas, cuja finalidade é abarcar imprevistas situações a serem solucionadas pelos tribunais na interpretação de cada caso. "Em vista disso, uma das mais equivocadas e, com frequiência, repetidas assertivas diz sobre a maior liberdade e o livre arbítrio dos juízes da Common Law, para criar o Direito, do que os juízes da Civil Law. Os juízes brasileiros são controlados apenas pelos recursos às instâncias superiores, sendo impassíveis de vinculação aos julgados anteriores". TIMM, Luciano Benetti. Função social do direito contratual no Código Civil brasileiro: justiça distributiva vs. eficiência econômica. Revista dos Tribunais, São Paulo, ano 97, v. 876, p. 25, out. 2008.

Em nossa opinião, o exemplo mais emblemático da possibilidade de insegurança jurídica que o novo sistema civilista pode trazer encontra-se no artigo 1.228 , $\S 4^{\circ}$, do CC/2002, que trata da desapropriação judicial fundada na posse "pro labore", denominação esta dada por Maria Helena Diniz (Código Civil anotado, cit., p. 979). Neste parágrafo o legislador se socorre de uma série de conceitos abertos ou indeterminados, que deverão ser analisados no caso concreto e permitirão, dependendo das condições sócio-econômicas da região em que se encontre o imóvel, decisões das mais variadas. O que se entende por extensa área? O que é número considerável de pessoas? O que significa obras e serviços de interesse social e econômico relevante? São todas estas perguntas que proporcionarão respostas das mais diversas.

118“"A aproximação da Justiça, aqui como em muitas outras situações, faz-se à custa de um aumento da insegurança. Torna-se difícil para a pessoa comum, e até para o operador do Direito, prever qual será a solução dum caso concreto. As variações entre os juízos individuais aumentam e as possibilidades de erro são muito maiores.” ASCENSÃO, José de Oliveira. Cláusulas gerais e segurança jurídica no Código Civil de 2002 , cit., p. 81. 
em virtude de suas funções na sociedade, como dizia Norberto Bobbio em seu livro "Da estrutura à função". 119

Vale dizer, todo direito subjetivo ${ }^{120}$ deve ser exercido em consonância com sua função social, ${ }^{121}$ não sendo tão importante o estudo de sua estrutura, seu conteúdo e seus elementos técnicos, mas sim o resultado esperado pelo Direito com sua implementação.

Dentre esses institutos, podemos tratar da nulidade dos atos jurídicos e suas reais consequências no mundo do direito.

Aquele pensamento fechado ${ }^{122}$ e tecnicista que vigorava e que foi espraiado em obras literárias de que o nulo não produz efeitos ${ }^{123}$ para o sistema jurídico, foi se tornando falso com o passar dos tempos, porquanto o nulo, realmente, não produz os efeitos almejados pelas partes. Contudo, não deixam de construir fatos jurídicos que terão importância e proteção perante o sistema.

\footnotetext{
${ }^{119}$ Nesta obra Bobbio critica sem deixar de enaltecer as sua virtudes, a Teoria pura do direito de Kelsen, afirmando que esta teoria, da maneira como foi concebida, não se preocupara com a função do direito. "Em poucas palavras, aqueles que se dedicaram à teoria geral do direito se preocuparam muito mais em saber "como o direito é feito" do que "para que o direito serve". BOBBIO, Norberto. op. cit., p. 53-54.

${ }^{120}$ Nas lições de Sílvio Rodrigues, "o direito objetivo é a norma posta a viger num determinado momento, para reger as relações dos homens vivendo em sociedade; é a norma agendi e o direito subjetivo é a prerrogativa que para o indivíduo decorre da norma objetiva, quando ele é o titular do direito; é a facultas agendi. Cada vez que se fala em direito subjetivo, isto é, em facultas agendi, ou seja, numa relação jurídica de onde decorre uma prerrogativa para alguém, imprescindível se faz conceber o titular dessa prerrogativa; porque não há direito subjetivo que não tenha sujeito, pois o direito tem por escopo proteger os interesses humanos. O direito subjetivo consiste numa relação jurídica que se estabelece entre um sujeito ativo - o titular desse direito - e um sujeito passivo, ou vários sujeitos passivos, que ou são responsáveis pelo cumprimento de uma obrigação para com o primeiro ou devem abster-se de qualquer comportamento que lhe possa prejudicar". RODRIGUES, Silvio. op. cit., v. 1, p. 36.

${ }^{121}$ Maria Clara Sottomayor assevera que: "O conceito de direito subjectivo esteve sujeito a uma evolução, sendo concebido actualmente não como um conceito exclusivamente individualista mas antes como uma posição de poder que pode ser funcionalizada à realização do interesse de outrem ou do interesse social". SOTOMAYOR, Maria Clara. Exercício do poder paternal: relativamente à pessoa do filho após o divórcio ou a separação de pessoas e bens. Porto: Publicações Universidade Católica, 2003. p. 24-25. (Estudos e Monografias).

${ }^{122 \text { ‘ }}$ Os códigos oitocentistas, como sistemas rígidos e fechados, impermeáveis às modificações econômicas e sociais, não têm mais lugar na sociedade hodierna. É preciso que os novos Códigos sejam um sistema que não seja fechado, que não seja aberto, mas que seja móvel, isto é, dotado de mobilidade tal a ensejar aperfeiçoamentos por intermédio do exercício, da aplicação e da interpretação das cláusulas gerais, cláusulas essas que são o motivo principal pelo qual se garantiu, até os dias de hoje, a sobrevivência do BGB, um dos mais perfeitos diplomas civis do mundo, ainda que seja fruto do liberalismo e da pandectistíca alemã dos séculos XVIII e XIX”. NERY JUNIOR, Nelson. Contratos no Código Civil, cit., p. 401.

${ }^{123}$ Miguel de Serpa Lopes, ao discorrer a respeito do pagamento efetuado ao incapaz, leciona que: “... já se não cogita da revalidação do ato nulo, mas de um enriquecimento indevido, que é reparado na proporção do que o incapaz lucrou em seu patrimônio. $\mathrm{O}$ ato nulo, não se contesta, nenhum efeito produz, mas, por outro lado, o princípio da equidade impõe que ninguém se locuplete com a fortuna alheia. Afastem-se, assim, os princípios regedores da nulidade e procure-se abrigo nos inerentes ao enriquecimento indevido, e a solução se nos afigura justa e incontestável". LOPES, Miguel de Serpa. Curso de direito civil. Rio de Janeiro: Freitas Bastos, 2000. v. 2, p. 178.
} 
Deveras, do ato ou negócio jurídico nulo pode-se chegar a outros resultados lícitos que, por conseguinte, terão tutela perante o ordenamento jurídico.

Um exemplo é a venda a non domino que, apesar de no rigor da técnica ser um ato inexistente, uma vez que na sua realização faltou um elemento essencial para o aperfeiçoamento do negócio jurídico, qual seja, a manifestação de vontade do verdadeiro proprietário do bem, esse negócio tem o condão de resultar, eventualmente, em posse de boa-fé, tendo, por conseqüência, a proteção do direito. ${ }^{124}$

No que tange aos institutos da incapacidade absoluta ou relativa que, para o sistema jurídico representam, como regra, a impossibilidade da prática de negócios jurídicos sem a devida complementação de manifestações de vontade daqueles que são responsáveis pelo incapaz, vislumbra-se que, na atual fase de evolução do direito, o regime do tudo ou nada em matéria atinente às incapacidades representa uma falácia.

O ordenamento como um todo traz, inclusive para os absolutamente incapazes, a oportunidade de praticar cada vez mais atos jurídicos que demonstram a relevância para o direito de suas expressões volitivas.

Podemos começar pelo casamento que, como é cediço, trata-se de um dos atos mais solenes diante de nossa legislação, daí a sua importância, podendo, não obstante, ser praticado pelo absolutamente incapaz produzindo todos os efeitos válidos.

Como é cediço, a idade núbil é de 16 anos. Contudo, em caso de gravidez e desde que haja o suprimento de idade por meio de alvará judicial, pode o menor impúbere casarse validamente. Assim, um adolescente de 15 anos pode, por exemplo, participar efetivamente da prática de um ato jurídico extremamente complexo e relevante, ainda que seja considerado absolutamente incapaz perante o nosso ordenamento jurídico.

É mister reconhecer, também, que o menor de 16 anos que se case sem observância de algumas formalidades exigidas, em razão de sua idade, não pratica ato nulo, o que seria a regra, mas ato anulável. Ou seja, nesse caso, o menor impúbere que pratica o ato jurídico em debate não terá declarado pelo sistema a sua nulidade com todos os seus corolários,

\footnotetext{
124، Deve-se ponderar, porém, que a afirmação de que o ato nulo não produz nenhum efeito não tem um sentido absoluto e significa, na verdade, que é destituído dos efeitos que normalmente lhe pertencem. Isto porque, algumas vezes, determinadas consequiências emanam do ato nulo, como ocorre no casamento putativo. Outras vezes, a venda nula não acarreta a transferência do domínio mas vale como causa justificativa da posse de boa-fé”. GONÇALVES, Carlos Roberto. op. cit., p. 156.
} 
mas poderá, eventualmente, ter esse ato desconstituído por ser anulável, podendo, contudo, ser ratificado.

Outro exemplo da relevância, para o direito, da manifestação de vontade do menor impúbere pode ser visualizado no capítulo atinente à adoção, em que o absolutamente incapaz tem uma participação preponderante nesse ato jurídico.

$\mathrm{O}$ artigo 45, $\S 2^{\circ}$, do Estatuto da Criança e do Adolescente assevera que: "Em se tratando de adotando maior de doze anos de idade, será também necessário o seu consentimento".

Assim, o absolutamente incapaz, com sua manifestação de vontade, pode dar ensejo à produção de atos jurídicos de relevada importância.

$\mathrm{O}$ artigo 53, III, do Estatuto da Criança e do Adolescente faculta às crianças (indivíduos menores de 12 anos) e aos adolescentes participarem de seus processos pedagógicos perante, as instituições de ensino.

Nos dizeres de Gustavo Tepedino:

"Não se trata, portanto, de afirmar que a manifestação de vontade do incapaz é elemento suficiente para a criação de vínculos jurídicos. Aliás como afirma Perlingieri, nem mesmo para aqueles considerados capazes a mera manifestação de vontade é elemento suficiente a criação de vínculos pois: "Autonomia não é arbítrio: o ato de autonomia em um ordenamento social não se pode eximir um valor positivo." Porém, frente a situações que toquem diretamente ao desenvolvimento de sua própria personalidade, não pode mais ser admitido em nosso sistema que a vontade do incapaz seja irrelevante ou desprezada pelo Direito". ${ }^{125}$

Dessa forma, infere-se que acabou a fase dos extremos. Os institutos jurídicos permitem variantes em suas aplicações que podem ir bem além do gramaticalmente extraído de seus textos normativos.

\footnotetext{
${ }^{125}$ TEPEDINO, Gustavo (Coord.). A parte geral do novo Código Civil: estudos na perspectiva civilconstitucional. 3. ed. Rio de Janeiro: Renovar, 2007. p. 27.
} 


\subsection{A Emancipação}

A incapacidade deixa de existir quando cessadas as circunstâncias ensejadoras de proteção jurídica. Assim, o escopo da incapacidade é tutelar o indivíduo.

O sistema, como acima foi explicitado, apesar de conferir a toda pessoa natural a capacidade de direito, restringe em algumas circunstâncias a possibilidade de por si mesma praticar qualquer ato jurídico, desde que se encontre inserida em alguma situação da vida, legalmente qualificada, como restritiva da sua autonomia da vontade.

A emancipação, prevista no parágrafo único do artigo $5^{\circ}$ do Código Civil de 2002 , é a aquisição antecipada da plena capacidade civil. ${ }^{126}$

Como é cediço, capacidade é a medida da personalidade, sendo esta a "aptidão genérica para adquirir direitos e contrair obrigações". ${ }^{127}$

Alguns doutrinadores, ${ }^{128}$ ao interpretar o artigo acima referido, dividem a emancipação em legal e voluntária, havendo aqueles que entendem existir uma terceira modalidade de emancipação que seria a emancipação judicial.

Preconiza o artigo 5 do Código Civil de 2002 que: "A menoridade cessa aos dezoitos anos completos, quando a pessoa fica habilitada à prática de todos os atos da vida civil".

Nesse diapasão, como já relatado, houve uma antecipação, se compararmos com o Código de 1916, em relação à idade que a pessoa deve atingir para a plena capacidade. Passou dos 21 para os 18 anos a idade mínima para a obtenção da capacidade de fato da pessoa natural.

O fundamento fático em que se inspirou o legislador, ao reduzir a idade de 21 para 18 anos, com as consequências supra-referidas, foi o avanço tecnológico da sociedade hodierna, que permite a obtenção de informações por vários meios de comunicação, em

\footnotetext{
${ }^{126}$ VENOSA, Sílvio de Salvo. op. cit., v. 1, p. 149; RODRIGUES, Silvio. op. cit., v. 1, p. 57; MONTEIRO, Washington de Barros. op. cit., v. 1, p. 66.

${ }^{127}$ GONÇALVES, Carlos Roberto. op. cit., p. 35.

${ }^{128}$ GAGLIANO, Pablo Stolze; PAMPLONA FILHO, Rodolfo. Novo curso de direito civil: parte geral. 10. ed. São Paulo: Saraiva, 2008. v. 1, p. 105; AZEVEDO, Álvaro Villaça; NICOLAU, Gustavo Rene. Código Civil comentado. Das Pessoas e dos Bens. Artigos 1 a 103. São Paulo: Atlas, 2007. v. 1, p. 32; FIÚZA, César. Direito civil: curso completo. 11. ed. Belo Horizonte: Del Rey, 2008. p. 133.
} 
tempo real, o que resultou uma antecipada maturidade da pessoa. Dessa maneira, a idade antes estipulada pelo Código Civil de 1916 não mais se justificava.

A codificação, como conseqüência natural da vida em sociedade, tem como um dos principais fundamentos a criação de um sistema jurídico mais compatível com a realidade social.

Para alguns doutrinadores, a maioridade civil aos 21 anos era incompatível com as exigências da sociedade contemporânea, ${ }^{129}$ colocando o ordenamento jurídico brasileiro em desconformidade com outros sistemas mais avançados, como é o caso do CC da Alemanha (art. $2^{\circ}$ ), Suiça $\left(\operatorname{art.} 4^{\circ}\right.$ ), França (art.488), Portugal (art. 122 $)$ e Itália (art. $2^{\circ}$ ). Diferentemente, o Código Civil japonês estipula a maioridade aos 20 (vinte) anos completos, de acordo com o seu art. $3^{\circ}$.

Outro fator preponderante, para justificar a redução da idade em debate, foi a disparidade existente entre o Código Civil e outros diplomas legislativos brasileiros ${ }^{130}$ que já consideravam a idade de 18 anos relevante para a produção de determinados efeitos jurídicos, tais como o Código Penal, que considera imputável a pessoa humana a partir dos 18 anos. $^{131}$

Vale dizer, ainda, que o voto é obrigatório a partir dos 18 anos. ${ }^{132}$ Isso significa que a pessoa deve participar da vida política do país a partir dessa idade, podendo, também, exercer a vereança com 18 anos.

No entanto, a cessação da incapacidade aos 18 anos pode representar, muitas vezes, problemas a serem enfrentados pelo estudioso do direito, vez que surgirão fatos jurídicos produtores de responsabilidade civil que ressentirão da adequada resposta pelo sistema,

\footnotetext{
${ }^{129}$ LOTUFO, Renan. Código Civil comentado: parte geral. São Paulo: Saraiva, 2003. v. 1, p. 29.

${ }^{130}$ Renan Lotufo explicita as razões que levaram o Senado a diminuir a idade, de aquisição da plena capacidade, de 21 para 18 anos, aduzindo que o texto original do Código Civil de 2002 mantinha os 21 anos, não obstante, a Emenda n.1 do Senado Federal ensejou a alteração que foi acatada. Explica, ainda, que a justificativa do Senado foi a tendência mundial no sentido de fixar a maioridade civil em 18 anos, assim como o fato da legislação pátria trazer uma série de dispositivos que já conferiam responsabilidade ao indivíduo com a referida faixa etária. São exemplos: a imputabilidade penal aos maiores de 18 anos (Código Penal, art. 27), a obrigatoriedade do voto aos maiores de 18 anos (Constituição Federal, art. 14, § $\left.1^{\circ}, \mathrm{I}\right)$, a capacidade eleitoral passiva para o exercício da vereança a partir dos 18 anos, etc. A influência dos veículos de comunicação também foi um fator preponderante para a debatida diminuição da idade para a aquisição da capacidade de fato. LOTUFO, Renan. Código Civil comentado: parte geral, cit., v. 1, p. 29.

131،Art. 27. Os menores de 18 (dezoito) anos são penalmente inimputáveis, ficando sujeitos às normas estabelecidas na legislação especial".

${ }^{132} \mathrm{CF} / 88$, art. $14, \S 1^{\circ}$, I.
} 
porquanto não será possível a tão almejada volta ao status quo ante em razão de certas peculiaridades a serem identificadas.

O atingimento da capacidade com a idade debatida poderá representar transtorno para o instituto da responsabilidade civil, pois da mesma forma que a pessoa com 18 anos tem condição de praticar ato lícito, possui a mesma possibilidade de praticar ato ilícito ensejador do dever de indenizar.

Com efeito, presentes os requisitos da responsabilidade civil, o agente causador do prejuízo deve responder com seu patrimônio pelos danos causados à esfera jurídica de direitos de terceiro. Não obstante, pergunta-se: será que com a idade de 18 anos o sujeito já possui patrimônio idôneo para arcar com sua responsabilidade?

A resposta, na maioria das vezes negativa, agrava a situação da vítima, porquanto, em um primeiro momento, ao adquirir a plena capacidade, a pessoa se liberta de seu vínculo com seu representante legal, deixando aquele que sofreu dano em seus direitos, ocasionado por um jovem nessas circunstâncias, impossibilitado em muitas ocasiões de se restabelecer.

O parágrafo único, do artigo $5^{\circ} \mathrm{em}$ comento, traz um rol de circunstâncias que redundarão na plena capacidade da pessoa ainda que não tenha atingido a idade mínima de 18 anos.

Antes de adentrarmos nas peculiaridades da emancipação de acordo com a codificação atual, vale a pena sintetizar as mudanças engendradas pelo artigo $5^{\circ}$ do CC de 2002 em comparação ao artigo 9 do Código Civil de 1916.

De uma maneira geral, pode-se visualizar uma grande semelhança entre o texto anterior, em seu artigo $9^{\circ}$, e o novo artigo $5^{\circ}$, exceto quanto à aquisição da maioridade aos 18 anos, de acordo com a referência acima. ${ }^{133}$

Algumas pequenas modificações de vocábulo, como ocorreu com a expressão "colação de grau em curso de ensino superior" que antes aduzia o artigo $9^{\circ}$, parágrafo $1^{\circ}$, IV, "pela colação de grau científico em curso de ensino superior", imposto pela atual codificação civil. Na realidade, nenhuma alteração hermenêutica provocou tal mudança.

${ }^{133}$ RIZZARDO, Arnaldo. Parte geral do Código Civil. 6. ed. Rio de Janeiro: Forense, 2008. p. 224. 
Demais disso, o inciso $\mathrm{V}$, do artigo $5^{\circ}$, do atual Código Civil incluiu como fatores desencadeadores da aquisição da plena capacidade, além das hipóteses de estabelecimento civil ou comercial, já anteriormente previstas no Código Civil de 1916, a relação de emprego, desde que o menor com 16 anos completos tenha economia própria.

Fala-se, então, como já adiantado, em emancipação legal, voluntária e judicial. ${ }^{134}$

Com efeito, são as palavras do parágrafo único do artigo $5^{\circ}$ do atual Código Civil: “Cessará, para os menores, a incapacidade: I) pela concessão dos pais, ou de um deles na falta de outro, mediante instrumento público, independentemente de homologação judicial, ou por sentença do juiz, ouvido o tutor, se o menor tiver dezesseis anos completos".

Neste inciso $1^{\circ}$, podemos vislumbrar, em sua primeira parte, a denominada emancipação voluntária, resultante de ato de vontade, principalmente dos pais, ou de apenas um deles se o outro genitor estiver impossibilitado de participar desse ato jurídico, em que o menor, desde que com 16 anos completos, adquira a plena capacidade.

Sobreleva ressaltar que a aquisição, nessa circunstância, da plena capacidade se dará por instrumento público, sem a necessidade de participação judicial, sendo suficiente o simples desconhecimento do paradeiro de um dos genitores para que o outro possa sozinho proceder a outorga, sem embargo da necessidade, a priori, da participação de ambos os genitores.

Nos dizeres de Nelson Nery Junior e Rosa Maria de Andrade Nery:

"A norma fala em ato de concessão dos pais, de modo que não exige a intervenção do filho emancipado para o aperfeiçoamento e validade do ato de emancipação. Contudo, para que não se coloque em dúvida a intenção dos pais, nem se alegue que a emancipação está sendo feita para que os pais se livrem da obrigação de sustento do filho, é conveniente que o filho emancipado participe do ato como anuente". ${ }^{135}$

\footnotetext{
${ }^{134}$ GONÇALVES, Carlos Roberto. op. cit., p. 156; GAGLIANO, Pablo Stolze; PAMPLONA FILHO, Rodolfo. op. cit., v. 1, p. 105; AZEVEDO, Álvaro Villaça; NICOLAU, Gustavo Rene. op. cit., v. 1, p. 32; FIÚZA, César. op. cit., p. 133.

${ }^{135}$ NERY JÚNIOR, Nelson; NERY, Rosa Maria de Andrade. Código Civil comentado. 6. ed. rev. ampl. e atual. São Paulo: Ed. Revista dos Tribunais: 2008. p. 204.
} 
A segunda parte do inciso em debate trata da conceituada emancipação judicial, ${ }^{136}$ vez que dependerá de sentença judicial, após a oitiva do tutor, desde que, também, nesse caso, o menor tenha ao menos 16 anos completos.

O casamento é, de acordo com o parágrafo único, inciso II, do artigo em testilha, causa de emancipação legal, sendo relevante esclarecer que nesse caso não se menciona uma idade mínima para que seja atingida a plena capacidade. O menor de 16 anos, ${ }^{137}$ casando-se, poderá adquirir a capacidade de fato.

É preciso ressaltar que a idade núbil de acordo com o nosso sistema é de 16 anos, ${ }^{138}$ no entanto, é possível que o adolescente que não tenha essa idade case, desde que em razão de gravidez obtenha alvará de suprimento de idade, o que legalizará para todos os efeitos o casamento implicando, apenas, a imposição do regime de separação obrigatória de bens. ${ }^{139}$

Não há restabelecimento da incapacidade pela dissolução do casamento ou da sociedade conjugal. Entretanto, há aqueles que entendem, como é o caso de Pontes de Miranda ${ }^{140}$, que a declaração de nulidade do casamento tem o condão de revogar a emancipação, porque perderia ela o suporte jurídico ensejador da aquisição antecipada da capacidade de fato. Outros autores entendem, como é o caso de Renan Lotufo ${ }^{141}$, Gustavo Tepedino, ${ }^{142}$ Pablo Stolze Gagliano e Rodolfo Pamplona ${ }^{143}$, Silvio Rodrigues ${ }^{144}$, que o casamento putativo produziria o efeito de emancipar o cônjuge possuidor de boa-fé. ${ }^{145}$

\footnotetext{
${ }^{136}$ GONÇALVES, Carlos Roberto. op. cit., p. 156; GAGLIANO, Pablo Stolze; PAMPLONA FILHO, Rodolfo. op. cit., v. 1, p. 105; AZEVEDO, Álvaro Villaça; NICOLAU, Gustavo Rene. op. cit., v. 1, p. 32; FIÚZA, César. op. cit., p. 133.

${ }^{137}$ RIZZARDO, Arnaldo. op. cit., p. 226.

138“Art. 1517. O homem e a mulher com dezesseis anos podem casar, exigindo-se autorização de ambos os pais, ou de seus representantes legais, enquanto não atingida a maioridade civil".

139، "Art. 1641. É obrigatório o regime da separação de bens no casamento: ...III - de todos os que dependerem, para casar, de suprimento judicial".

${ }^{140}$ PONTES DE MIRANDA, Francisco Cavalcanti. Tratado de direito privado. São Paulo: Ed. Revista dos Tribunais, 1974. v. 1, p. 201-202.

${ }^{141}$ LOTUFO, Renan. Código Civil comentado: parte geral, cit., v. 1, p. 31.

${ }^{142}$ TEPEDINO, Gustavo (Coord.). op. cit., p. 23.

${ }^{143}$ GAGLIANO, Pablo Stolze; PAMPLONA FILHO, Rodolfo. op. cit., v. 1, p. 107.

Arnaldo Rizzardo assevera que: “...uma vez casada, a pessoa adquire plena capacidade civil, não importando que em seguida seja dissolvido o vínculo conjugal pela morte, ou pela anulação, ou pelo divórcio. Não retorna o ex-cônjuge ao estado de menor. A maioridade alcançada torna-se irreversível, mesmo tendo a pessoa menos de dezesseis anos de idade. RIZZARDO, Arnaldo. op. cit., p. 226.

${ }^{144}$ RODRIGUES, Silvio. op. cit., v. 1, p. 59-60.

${ }^{145}$ Não obstante, Washingtom de Barros Monteiro não diferencia as consequências jurídicas do casamento putativo para o cônjuge de boa ou de má-fé. Ele apenas aduz que a posterior declaração de nulidade não teria o condão de ocasionar o retorno do emancipado à incapacidade. MONTEIRO, Washington de Barros. op. cit., v. 1, p. 67.
} 
É mister esclarecer que poucos autores, ${ }^{146}$ quando tratam em seus livros da emancipação pelo casamento, mencionam a união estável como instituto apto a produzir o mesmo efeito emancipador do casamento. Nestor Duarte ${ }^{147}$ é um deles que, categoricamente, refuta a possibilidade de se emancipar pela união estável. Uma das justificativas, em nossa opinião, para essa diferenciação de tratamento entre as duas formas de entidades familiares, seria a falta de segurança e de objetividade no caso de união estável que, muitas vezes, é de difícil reconhecimento, exigindo, não rara vez, ação judicial própria com abertura de complexa fase instrutória.

Para Álvaro Villaça Azevedo e Gustavo Rene Nicolau a união estável teria o condão de emancipar nas mesmas condições em que o casamento emancipa. ${ }^{148}$

O exercício de emprego público efetivo também é causa de emancipação legal, contudo é curial explicitar que, dificilmente uma pessoa menor de 18 anos assumirá cargo ou emprego público em virtude das responsabilidades atinentes a esses misteres.

De acordo com o princípio constitucional do concurso público, ${ }^{149}$ previsto no art. 37, II, da CF, a investidura em cargo ou emprego público depende da submissão e êxito do candidato em concurso público de provas ou de provas e títulos, respeitando-se a natureza e a complexidade do cargo ou emprego, na forma prevista em lei, ressalvadas as nomeações para cargo em comissão de livre nomeação e exoneração. Cargo público de provimento efetivo depende de aprovação em concurso público e só, nessa hipótese, cessará para os menores a incapacidade. ${ }^{150}$

A assunção de cargos de provimento em comissão, cuja investidura independe de aprovação prévia em concurso público, assim como admissões em processos seletivos, que diferem do concurso público em termos de complexidade, não têm o condão de determinar o fim da incapacidade. A contratação em empresas paraestatais, cujo regime jurídico

\footnotetext{
${ }^{146}$ Não tratam da união estável perante a emancipação: Nelson Nery Júnior e Rosa Maria de Andrade Nery (Código Civil comentado, cit.); Roberto Senise Lisboa, Cezar Fiúza, Renan Lotufo (LOTUFO, Renan. Código Civil comentado: parte geral, cit., v. 1), Maria Helena Diniz (Curso de direito civil brasileiro: teoria geral do direito civil. 24. ed., cit.), Sílvio de Salvo Venosa (Direito civil: parte geral. 7. ed. São Paulo: Atlas, 2007. v. 1), entre outros.

${ }^{147}$ PELUSO, Cezar, Ministro (Coord.). Código Civil comentado. Barueri/SP: Manole, 2007. p. 20.

${ }^{148}$ AZEVEDO, Álvaro Villaça; NICOLAU, Gustavo Rene. op. cit., v. 1.

${ }^{149}$ MELLO, Celso Antonio Bandeira de. Curso de direito administrativo. 17. ed. São Paulo: Malheiros Ed., 2004. p. 256.

${ }^{150}$ DUARTE, Nestor. Código Civil comentado. Coordenadora Regina Beatriz Tavares da Silva. 6. ed. São Paulo: Saraiva, 2008. p. 20.
} 
aplicado, em regra, é o de direito privado, para Nestor Duarte, não fundamentaria a cessação da incapacidade. ${ }^{151}$

Dissertando opinião em contrário, têm-se as explicações de Carlos Roberto Gonçalves $^{152}$ para quem o exercício de emprego público, independentemente da denominação jurídica que o agente público conquiste, já é condição bastante para a emancipação. O simples fato de assumir a condição de agente público demonstra maturidade suficiente, ainda mais porque a simples relação de emprego com economia própria já é considerada fator legal para a obtenção da capacidade de fato (art. $5^{\circ}$, parágrafo único, V).

A colação de grau em curso superior também se configura em uma das modalidades de emancipação legal. Contudo, considerando o tempo que a pessoa despende para completar o primeiro e o segundo grau de ensino, dificilmente essa circunstância ocorrerá na prática.

A referida previsão é uma reminiscência do Código Civil de 1916, em que a idade para o atingimento da plena capacidade era 21 anos, situação que tornava possível, ainda que com não muita freqüência, a hipótese de emancipação legal em decorrência de colação de grau em curso superior.

Por fim, chegamos ao último caso de emancipação legal, previsto no artigo $5^{\circ}, \mathrm{V}$, do atual Código Civil, que aduz ser o estabelecimento civil ou comercial, assim como a existência de relação de emprego, desde que em função deles o menor com 16 (dezesseis) anos completos tenha economia própria, causas de obtenção da plena capacidade.

Nesse ponto, vale a pena tecer alguns comentários que auxiliam na fundamentação da ideia objeto da presente dissertação.

A redação do artigo $9^{\circ}, \mathrm{V}$, do Código Civil de 1916, como retromencionado, é muito parecida com a supracitada, deixando apenas de prever a situação do menor de poder emancipar-se em razão de emprego que lhe proporcione economia própria.

Deveras, o inciso em comento deixa nítida a importância, para o sistema jurídico, da independência econômica da pessoa como fator desencadeador da plena capacidade. Ou

\footnotetext{
${ }^{151}$ DUARTE, Nestor. op. cit., p. 20..

${ }^{152}$ GONÇALVES, Carlos Roberto. Direito civil brasileiro: parte geral. 6. ed. São Paulo: Saraiva: 2008. v. 1, p. 112 .
} 
seja, se a pessoa possuir economia própria, em razão de estabelecimento civil ou comercial, ou por motivo de emprego, se tiver 16 anos, será considerada plenamente capaz pelo sistema jurídico pátrio.

O principal motivo dessa forma de cessação de incapacidade, em um primeiro momento salta aos olhos, vez que não seria razoável a pessoa possuir estabelecimento empresarial, verbi gratia, e necessitar da assistência de seus responsáveis para praticar negócios jurídicos atinentes ao seu ramo de comércio.

Com efeito, para que o menor, nas condições explicitadas, possa exercer a sua atividade de forma livre e com segurança para terceiros que com ele celebrem contratos, mister se faz prescindir de qualquer obstáculo protetivo legal, como a assistência de seus responsáveis.

A novidade, no Código Civil de 2002, foi a previsão da cessação da incapacidade pela consecução de economia própria, em razão de emprego, desde que o adolescente tenha 16 anos.

Nesse caso, o sistema jurídico assevera que em uma sociedade extremamente capitalista como a nossa, em que a obtenção da dignidade humana depende de um patrimônio mínimo, a economia própria desencadeia a liberdade do indivíduo, assim como, a contrario sensu, a falta das mínimas condições econômicas geram a dependência plena da pessoa junto a alguém.

Para o ordenamento jurídico brasileiro, a obtenção de economia própria, pelos motivos listados no inciso $\mathrm{V}$, insere a pessoa com independência no mundo dos atos e negócios jurídicos, oferecendo, ademais, segurança para aqueles que contratam com o emancipado. $^{153}$

Destarte, a idade mínima de 16 anos somada à economia própria, em virtude de emprego ou estabelecimento civil ou comercial sinalizam maturidade ${ }^{154}$ para o sistema jurídico nacional e a consequente emancipação legal.

Ainda no que tange à emancipação, é curial esclarecer que, às vezes, dependendo da modalidade, pode ela servir de motivos escusos para elidir a responsabilidade dos

\footnotetext{
${ }^{153}$ GONÇALVES, Carlos Roberto. op. cit., v. 1, p. 47, RODRIGUES, Silvio. op. cit., v. 1, p. 61.

${ }^{154}$ RODRIGUES, Silvio. op. cit., v. 1, p. 61; GONÇALVES, Carlos Roberto. Direito civil brasileiro: parte geral, cit., v. 1, p. 47; MONTEIRO, Washington de Barros. op. cit., v. 1, p. 68.
} 
representantes legais, pelas obrigações alimentares ou pelos atos praticados por seus representados.

Assim, os tribunais já pacificaram, como já se fez referência, o entendimento de que a emancipação voluntária dos pais, prevista no artigo $5^{\circ}$, § único, I, não tem o condão de isentá-los, a priori, da responsabilidade civil por atos ilícitos praticados por seus filhos emancipados. ${ }^{155}$

Tem o mesmo teor, também, o enunciado no 39 do Conselho da Justiça Federal, aprovado nas Jornadas de Direito Civil que aduz: "a única hipótese em que poderá haver responsabilidade solidária do menor de 18 anos com seus pais é ter sido emancipado nos termos do art. $5^{\circ}$, parágrafo único, inc.I, do novo Código Civil."

Sobreleva ressaltar que, essa espécie de emancipação deve ocorrer sempre de acordo com os interesses do menor, não sendo apta a produzir os efeitos almejados pelos representantes, caso o escopo último seja a supressão do dever alimentar, ou outro motivo escuso qualquer, como o de retirar dos ombros dos genitores deveres decorrentes da falta de maturidade dos filhos. Ou seja, a emancipação, nesse caso, não produz, de acordo com nossos tribunais, todos os seus efeitos normalmente auferidos, porquanto a cessação antecipada da incapacidade não elidirá um importante aspecto do poder familiar, ou seja, a responsabilidade dos pais pelos atos danosos de seus filhos. ${ }^{156}$

\footnotetext{
${ }^{155}$ Neste sentido: EMENTA: Responsabilidade Civil - Menor Púbere - Ato Ilícito Praticado por Menor Emancipação de Menor - Responsabilidade Solidária - Legitimidade Passiva - Culpa in vigilando - Ônus da Prova - Cassação da sentença. O pátrio poder é "munus" público, é poder-dever, é encargo irrenunciável, insuscetível de renúncia ou autodestituição, e o genitor que dele se exonera, pela emancipação voluntária do menor púbere, em desacordo com a eventual imaturidade psíquica do filho menor, não evita a responsabilidade civil solidária, sendo parte legítima "ad causam" passiva na ação de reparação de danos por ato ilícito do filho, calcada no art. 159 do Código Civil, inteligência do art. 1518, parágrafo único, do mesmo Código. É de mérito a decisão que investiga a ocorrência da responsabilidade, fundada na culpa "in vigilando", a induzir a solidariedade da mãe, presunção que beneficia a vítima, cabendo aos pais do ofensor o ônus da prova. (IRP) (Apelação Cível, número do processo: 1995.001.07652, Oitava Câmara Cível, Unânime, Des. Carpena Amorim, julgado em 6/02/96).

Outrossim, nesta linha de pensamento tem-se: "Ainda que o filho menor púbere seja emancipado, o pai, não obstante, é responsável pela reparação do dano por ele causado" (RTJ, 62/108). "A emancipação por outorga dos pais não exclui, por si só, a responsabilidade de atos ilícitos do filho" (RSTJ, 115/275). "Não é nulo, mas ineficaz, o ato de emancipação em face de terceiros e do menor. Desavém ao pai utilizá-la para descartar-se da responsabilidade pelos atos do filho menor na idade em que os riscos se maximizam" (RT, 639/172).

${ }^{156}$ Neste sentido, são as precisas palavras de Carlos Roberto Gonçalves: "Tal espécie de emancipação só não produz, segundo a jurisprudência, inclusive do STF, o efeito de isentar os pais da obrigação de indenizar as vítimas dos atos ilícitos praticados pelo menor emancipado, para evitar emancipações maliciosas. Entendese que os pais não podem, por sua exclusiva vontade, retirar de seus ombros responsabilidade ali colocada pela lei. Essa afirmação só se aplica, pois, às emancipações voluntariamente outorgadas pelos pais, não às demais espécies." GONÇALVES, Carlos Roberto. Direito civil brasileiro: parte geral, cit., v. 1, p. 109; COELHO, Fábio Ulhoa. Curso de direito civil. 2. ed. São Paulo: Saraiva, 2006. v. 1, p. 167.
} 
Arnaldo Rizzardo, ${ }^{157}$ ao comentar a mesma situação, assevera ser relevante notar que, perante terceiros, no que tange à responsabilidade civil, a emancipação voluntária não desvincula o menor dos seus responsáveis pelos atos ilícitos que porventura venha a praticar. Ocorre que, com relação a terceiros, a aquisição da capacidade de fato, antes da maioridade, não elide a solidariedade dos pais pelos atos de seus filhos que se encontrarem sob sua autoridade, de acordo com as regras do art. 932, inc. I, do Código Civil (art. 1.521, inc. I, do Código anterior), independentemente da culpa, haja vista o previsto no artigo 933 do mesmo Código. Ocasionado o prejuízo na esfera jurídica de terceiros, por ilícito cometido pelo filho menor, ainda que não presente a falta do dever de vigiar, a responsabilidade solidária dos genitores deve ser reconhecida, caso contrário, o instituto da emancipação voluntária poderia tornar-se um instrumento para eximir os responsáveis do dever de indenizar os danos que, eventualmente, os seus filhos menores venham a causar a terceiros.

Então, pergunta-se: Onde está o dispositivo legal que mitiga os efeitos em relação a essa espécie de emancipação? Não há. Como referido acima, trata-se de interpretação doutrinária e jurisprudencial que presume, inadvertidamente, em nossa opinião, a má-fé de todas as emancipações voluntárias. ${ }^{158}$

Não obstante esse pensamento ser predominante na doutrina e jurisprudência, entendemos que não é possível presumir, aprioristicamente, a má-fé da emancipação voluntária e, por conseguinte, o impedimento de todos os efeitos que dela, naturalmente, poderiam decorrer, principalmente o de excluir a responsabilidade dos pais pelos atos ilícitos dos filhos.

\footnotetext{
${ }^{157}$ RIZZARDO, Arnaldo. op. cit., p. 225.

${ }^{158} \mathrm{Em}$ nossa opinião esta interpretação jurisprudencial, apesar de em muitas oportunidades onerar desmotivadamente os pais, haja vista o fato de que por vezes a emancipação é reflexo da maturidade e independência econômica do filho, é um clássico exemplo da força criativa de nossos Tribunais na aplicação da lei, conferindo inclusive um sentido contra legen ao instituto da emancipação, porquanto em nenhum artigo de lei é possível extrair, diretamente, este pensamento restritivo quanto aos efeitos da emancipação voluntária. Esse significado interpretativo seria mais adequado, caso, após a emancipação, o filho continuasse dependente economicamente dos pais. Essa força criadora da jurisprudência é retratada por Piero Calamandrei quando aduz que: "A sentença não surge diretamente da lei: surge da consciência do juiz, estimulada por múltiplos motivos psicológicos, entre os quais a lei constitui o motivo mais importante, mas não o único; um motivo que, para se transformar em sentença, tem que se encontrar e se fundir, como num crisol, com o resto dos motivos de ordem moral, em contato com os quais se transforma, de abstrata proposição lógica, em concreta vontade individual. A contraposição entre legalidade e o direito livre, como se fossem dois sistemas opostos e inconciliáveis entre si, é na prática jurisprudencial muitos menos absoluta e rigorosa do que se lê nos livros". CALAMANDREI, Piero. op. cit., v. 3, p. 200.
} 
É mister reconhecer o seguinte: desde que o filho seja desvinculado, economicamente por completo, dos pais, e o ato não seja praticado com o intuito de se livrar de obrigações decorrentes do desvio de conduta dos descendentes, o ordenamento jurídico deve ser interpretado no sentido de se conceder a máxima efetividade à emancipação, ainda que voluntária.

Assim, a emancipação voluntária deve manter correspondência com a realidade fática a fim de permitir a cessação da responsabilidade civil dos pais pelos atos ilícitos de seus descendentes. De forma que, se o filho, emancipado voluntariamente pelos pais, continua a ser economicamente dependente de seus progenitores, é axiomático que a emancipação realizou-se apenas no plano formal, o que demonstra que o emancipado não atingiu a maturidade necessária para a aquisição da capacidade de fato, persistindo juridicamente a obrigação dos pais de indenizar os prejuízos causados por seus filhos. ${ }^{159}$

Para José Fernando Simão, a presunção relativa, criada pela doutrina e jurisprudência, de que toda emancipação voluntária possui motivos escusos e, em virtude disso, não libera os pais das consequências dos atos ilícitos praticados pelos seus filhos emancipados, é exagerada, ainda mais se considerarmos que a responsabilidade por fato de terceiro é excepcional perante o nosso sistema e não a regra. O que deve ser analisado é o caso concreto para verificar se, de fato, o menor emancipado continua ou não dependente dos pais física e economicamente. Não podemos esquecer que a boa-fé é que deve ser sempre presumida e não a má-fé. ${ }^{160}$

Por fim, é imperioso reconhecer que as formas acima explicitadas de emancipação não têm o condão de produzir efeitos perante todos os ramos do Direito, padecendo o emancipado, em certas situações, de limitação para a prática de atos regulados por outros campos da ciência jurídica, ainda que absolutamente capaz. ${ }^{161}$

As normas sobre capacidade, previstas na Parte Geral do Código Civil, possuem caráter geral e cedem espaço diante de regras específicas. Dessa forma, por exemplo, a jovem que contrai matrimônio com 14 ou 15 anos de idade, obedecendo às formalidades legais, não pode, mesmo emancipada, obter título de eleitora antes da idade

\footnotetext{
${ }^{159}$ KARAM, Munir. Responsabilidade civil dos pais pelo fato do filho. In: FRANÇA, Rubens Limongi (Org.). Enciclopédia Saraiva do Direito, São Paulo: Saraiva, 1981. v. 65, p. 404.

${ }^{160}$ SIMÃ̃, José Fernando. op. cit., p. 176.

${ }^{161}$ De acordo com nossa Carta Magna, em seu art. $14, \S 1^{\circ}$, I, por exemplo, o voto é obrigatório apenas aos maiores de 18 anos, são sendo relevante a emancipação da pessoa neste caso.
} 
constitucionalmente prevista, porquanto o Código Eleitoral exige idade mínima de 16 anos. Também, não possibilita a obtenção de carteira de habilitação para dirigir veículos automotores, porque a idade mínima estabelecida pelo Código de Trânsito Brasileiro é de 18 anos. Pode, ainda, pelo mesmo motivo ter o seu ingresso impedido em lugares que, de acordo com o Estatuto da Criança e do Adolescente, somente podem ser frequentados por pessoas maiores de idade. ${ }^{162}$

Ademais, os doutrinadores entendem que em qualquer caso a emancipação é irrevogável. ${ }^{163}$

Assim, pode-se concluir, de uma maneira mais consentânea com a evolução do direito pátrio, que a maioridade do filho, por si só, não terá o condão de afastar a responsabilidade dos pais pelos atos ilícitos praticados por eles. Se há quem entenda, como já demonstrado, que a emancipação voluntária não poderá eliminar a responsabilidade civil dos genitores, caso o emancipado mantenha-se economicamente dependente, é imperioso reconhecer que o ponto fulcral para solucionar essa questão deve ser a existência ou não de dependência econômica dos filhos em relação a seus progenitores.

\footnotetext{
${ }^{162}$ GONÇALVES, Carlos Roberto. Direito civil brasileiro: parte geral, cit., v. 1, p. 112.

${ }^{163}$ Id. Direito civil: parte geral, cit., p. 156; LOTUFO, Renan. Código Civil comentado: parte geral, cit., v. 1, p. 34; VENOSA, Sílvio de Salvo. Direito civil: parte geral. 6. ed., cit., v. 1, p. 150. GAGLIANO, Pablo Stolze; PAMPLONA FILHO, Rodolfo. op. cit., v. 1, p. 107; FIÚZA, César. op. cit., p. 134; LISBOA, Roberto Senise. Manual de direito civil: obrigações e responsabilidade civil, cit., v. 2, p. 316. Contra, entendendo que a emancipação em razão de estabelecimento civil ou comercial ou pela relação de emprego, desde que em ambas as situações o menor possua economia própria é resolúvel, desde que o emancipado perca esta condição, está a doutrina de Nestor Duarte, em Código Civil comentado, cit., p. 21.
} 


\section{DO PODER FAMILIAR}

Indubitavelmente, a Carta Magna de 1988 constituiu um marco histórico para o direito infraconstitucional, pois criou novos paradigmas para todos os ramos do direito, mudando conceitos tradicionalíssimos, inclusive no campo do direito de família, ${ }^{164}$ instituindo uma série de normas formalmente constitucionais ${ }^{165}$ as quais regulamentaram e modernizaram a espinha dorsal das relações familiares, no seio da sociedade.

A família, no texto de 1988, sofreu uma alteração muito grande, pois adquiriu a função social que tanto exigia a complexidade e a evolução da vida moderna.

Nessa esteira, o constituinte originário, utilizando os atributos de um poder ilimitado juridicamente, de um momento para o outro colocou por terra uma série de artigos discriminatórios, ${ }^{166}$ referentes ao direito de família, que hierarquizavam demasiadamente a família brasileira.

Essas mudanças, engendradas pela Constituição de 1988, ocorreram em razão da sensibilidade do legislador em perceber o surgimento de certos comportamentos sociais na sociedade brasileira, máxime com relação às estruturas familiares, que já não mais suportavam os ditames impostos pelo Código Civil de 1916, extremamente discriminatório, hierarquizado, patrimonialista e matrimonializado em relação ao direito de família. ${ }^{167}$

\footnotetext{
${ }^{164}$ Vale a pena mencionar que a Declaração Universal dos Direitos do Homem, em seu artigo XVI, 3, estabeleceu: "A família é o núcleo natural e fundamental da sociedade e tem direito à proteção da sociedade e do Estado."

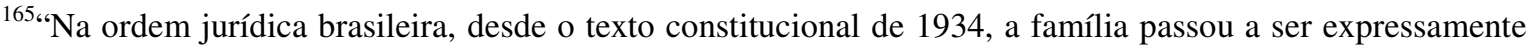
tratada em nível constitucional, a despeito das críticas feitas por alguns ao legislador constituinte, sob o argumento de que tal assunto não era materialmente constitucional." GAMA, Guilherme Calmon Nogueira da. op. cit., p. 28.

${ }^{166} \mathrm{O}$ exemplo mais emblemático desta discriminação era encontrado no caput artigo 233, do Código Civil de 1916, que preconiza: "O marido é o chefe da sociedade conjugal, função que exerce com a colaboração da mulher, no interesse comum do casal e dos filhos".

${ }^{167}$ DIAS, Maria Berenice. Manual de direito das famílias. 4. ed. São Paulo: Ed. revista dos Tribunais, 2007. p. 43.
} 
O primeiro desses sintomas foi a constatação de que a família estava cada vez mais se concentrando para abarcar apenas os pais e filhos, circunstância essa que mitigou o conceito de família ${ }^{168}$ e recebeu o nome de nuclearização. ${ }^{169}$

Um outro fenômeno notado pelo legislador, que culminou com a ruína da família hierárquica, foi a democratização das relações familiares. ${ }^{170}$ Não mais predominava, nas sociedades conjugais, a estrutura hierarquizada ${ }^{171}$ prevista no Código de 1916. Na prática, o marido não era mais o chefe da sociedade conjugal, porque a mulher, com seu trabalho, se tornou cada vez mais independente e fortificada, não necessitando mais do esposo para a sua subsistência. ${ }^{172}$

Nesse sentido, eliminou-se o elemento despótico e a nossa Carta Maior, conseguintemente, igualou homens e mulheres perante a sociedade conjugal. É o que está expressamente previsto no art. 226, parágrafo $5^{\circ}$, da $\mathrm{CF} / 88$, cujo caput ressalta a importância da família. ${ }^{173}$

Essa igualdade refletiu-se, também, com relação aos filhos que, de acordo com o artigo $227, \S 6^{\circ}$, da CF, ganharam a plena isonomia independentemente de suas origens. ${ }^{174}$

\footnotetext{
${ }^{168}$ Nas palavras de Rodrigo da Cunha Pereira: “...o conceito de família atravessa o tempo e o espaço, sempre tentando clarear e demarcar o seu limite, especialmente para os fins do Direito. Em uma determinada época, concebe-se a família como um organismo mais amplo, em outra, com tendência mais reduzida, como o é atualmente." PEREIRA, Rodrigo da Cunha. Direito de família: uma abordagem psicanalítica. Belo Horizonte: Del Rey, 1997. p. 19.

${ }^{169}$ A respeito da nuclearização da família, Eduardo de Oliveira Leite nos ensina que: "Esquematiza-se com traços marcantes a nova família: a família nuclear, que tende a se manter invulnerável até o final do século. Perdia a grande família, deslocava-se, para a sociedade conjugal, a primazia até então exercida pelo parentesco. Ganhava o casal, perdia, definitivamente, a família tronco. Perdia-se em quantidade de membros, ganhava-se na qualidade de afeto entre o reduzido círculo da família conjugal. Restringindo-se o nível de relacionamento ao pai, mãe e filhos, aumentava-se, proporcionalmente o estreitamento dos laços afetivos." (LEITE, Eduardo de Oliveira. Temas de direito de família. São Paulo: Ed. Revista dos Tribunais, 1994. p. 18).

${ }^{170}$ SOTOMAYOR, Maria Clara. op. cit., p. 22.

171، 'O casamento, até então, encarado prioritariamente como fonte de procriação e de afinidade torna-se um lugar de companheirismo. Desaparece a divisão de papéis, questiona-se o princípio da autoridade e eliminase a hierarquia, substituindo-se todos os aspectos pela linearidade dos sentimentos." LEITE, Eduardo de Oliveira. op. cit., p. 18.

${ }^{172}$ De acordo com Guilherme Calmon Nogueira da Gama: “As famílias devem espelhar a própria formação democrática do convívio em sociedade, sob o prisma político-ideológico, fundando-se em valores existenciais e psíquicos, próprios do ser humano, como os sentimentos de solidariedade, afeto, respeito, compreensão, que afastam os valores autoritários, materialistas, patrimonialistas e individualistas que nortearam a família matrimonial." GAMA, Guilherme Calmon Nogueira da. op. cit., p. 23.

${ }^{173}$ Art. 226, parágrafo $5^{\circ}$, "Os direitos e deveres referentes à sociedade conjugal são exercidos igualmente pelo homem e pela mulher."

${ }^{174}$ Art. 227, parágrafo $6^{\circ}$, “Os filhos, havidos ou não da relação do casamento, ou por adoção, terão os mesmos direitos e qualificações, proibidas quaisquer designações discriminatórias relativas à filiação.”
} 
Outra modificação, observada pelo legislador constituinte, foi a dessacralização do matrimônio, que se consubstanciava na idéia de que o casamento não mais era e nem podia continuar sendo o único instituto capaz de criar e dar guarida à família. ${ }^{175}$ Nesse sentido, o princípio do pluralismo de entidades é consagrado pelo nosso legislador constituinte originário, porquanto reconhece, expressamente, outras formas de arranjos familiares. ${ }^{176}$

O que norteava a convivência more uxoria de pessoas vivendo sob o mesmo teto, com vínculos afetivos sólidos e objetivo futuro em comum era apenas o afeto, independentemente de formalismos estatais.

Destarte, fala-se, a partir da análise dos diversos artigos constitucionais, acima citados, que têm como objeto o direito de família, no princípio do afeto que, em razão da constitucionalização do direito infraconstitucional, irradia efeitos para vários institutos desse ramo do direito civil complexo e permeado por constante emoção.

O princípio do afeto ${ }^{177}$ fundamenta as diversas entidades familiares explícita e implicitamente, ${ }^{178}$ reconhecidas pelo nosso ordenamento jurídico, e produz efeitos, outrossim, nas relações paterno-filiais.

Nesse contexto resumidamente delineado, em que a família perde a figura do "monarca absolutista", surgindo, por conseguinte, o elemento isonômico em todas as suas ramificações, a relação entre pais e filhos sofreu mudanças que culminaram, contemporaneamente, até na alteração da nomenclatura do instituto que regulamenta o exercício de direitos e deveres entre eles (pais e filhos).

Com efeito, o ordenamento jurídico brasileiro consagra, hodiernamente, o instituto do poder familiar, antes denominado de pátrio poder, ${ }^{179}$ que expressa o conjunto de direitos

\footnotetext{
175، A idéia de família para o Direito brasileiro sempre foi a de que ela é constituída de pais e filhos unidos a partir de um casamento regulado e regulamentado pelo Estado. Com a Constituição de 1988 esse conceito ampliou-se, uma vez que o Estado passou a reconhecer 'como entidade familiar a comunidade formada por qualquer dos pais e seus descendentes', bem como a união estável entre homem e mulher (art. 226). Isto significa uma evolução no conceito de família. Até então, a expressão da lei jurídica só reconhecia como família aquela entidade constituída pelo casamento. Em outras palavras, o conceito de família se abriu, indo em direção a um conceito mais real, impulsionado pela própria realidade.” PEREIRA, Rodrigo da Cunha. op. cit., p. 19.

${ }^{176}$ DIAS, Maria Berenice. op. cit., p. 64.

177،Ao serem reconhecidas como entidade familiar merecedora da tutela jurídica as uniões estáveis, que se constituem sem o selo do casamento, tal significa que o afeto, que une e enlaça duas pessoas, adquiriu o reconhecimento e inserção no sistema jurídico”. DIAS, Maria Berenice. op. cit., p. 67.

${ }^{178}$ Id. Ibid., p. 64.

179،"Em sentido legal, o pátrio poder é o todo que resulta do conjunto dos diversos direitos que a lei concede ao pai sobre a pessoa do filho-famílias". RODRIGUES, Lafayette. Direito de família. Atualizado com base no novo CC por Ricardo Rodrigues Gama. 1. ed. Campinas/SP: Russell, 2003. p. 253.
} 
e deveres inerentes ao vínculo jurídico unificador de pais e filhos menores e que, outrossim, sofreu modificações estruturais e funcionais na evolução do direito de família.

Esse poder familiar tem uma expressiva presença no passado do homem civilizado. Suas reais origens são extremamente remotas, o que dificulta sobremaneira a precisão quanto ao seu verdadeiro surgimento. De uma maneira geral, os doutrinadores fixam o ponto de partida evolutivo desse instituto no direito romano com o patria potestas, sendo considerado, consequentemente, a base nas legislações modernas. ${ }^{180}$

Não se pode olvidar que a organização familiar, de acordo com o direito antigo dos povos ocidentais, é regulada por dois sistemas: o romano e o germânico. ${ }^{181}$ Essa consideração influenciará o conteúdo e o desenvolvimento do plexo de direitos e deveres dos pais com relação aos filhos menores.

Deveras, o sistema romano, fundamento legislativo nos países de direito escrito, ${ }^{182}$ no que tange ao patria potestas, conferia um conteúdo absolutista de poderes ao pater em relação à vida e ao patrimônio de seus filhos. O chefe da família, como será relatado, gozava de soberania sobre os seus dependentes. Esse sistema não se preocupava com o bem estar dos filhos, uma vez que eles eram propriedade do pai, que podia dispor deles ao seu alvedrio. ${ }^{183}$

Por outro lado, o sistema germânico é considerado por alguns doutrinadores como o gérmen da doutrina da proteção integral, haja vista o fato de considerar o poder familiar um direito e um dever dos pais direcionados à tutela dos filhos. ${ }^{184} \mathrm{O}$ mundium não tinha a característica da vitaliciedade, os filhos, a partir do momento que ingressavam no exército, libertavam-se do poder dos pais. Ademais, tudo indica que os membros da família podiam ter patrimônio. ${ }^{185}$

O patria potestas, por outro lado, expressava-se por uma supremacia doméstica que girava ao redor de um chefe. O patriarcalismo, que vigorou durante a antiguidade, transmitiu os atributos principais à família romana. É dizer, o senhor supremo do lar era o

\footnotetext{
${ }^{180}$ GRISARD FILHO, Waldyr. Guarda compartilhada: um novo modelo de responsabilidade parental. 4. ed. São Paulo: Ed. Revista dos Tribunais, 2009. p. 37.

${ }^{181}$ ROCHA, J. V. Castelo Branco. O pátrio poder. 2. ed. São Paulo: Livr. e Ed. Universitária de Direito, 1978. p. 19.

${ }^{182}$ GRISARD FILHO, Waldyr. op. cit., p. 38.

${ }^{183}$ ROCHA, J. V. Castelo Branco. op. cit., p. 20.

${ }^{184}$ GRISARD FILHO, Waldyr. op. cit., p. 38.

${ }^{185}$ ROCHA, J. V. Castelo Branco. op. cit., p. 25.
} 
paterfamilias. Todos aqueles que compunham o grupo doméstico se submetiam a ele, que era a única pessoa sui iuris. ${ }^{186}$

Nessa linha lógica, o patria potestas caracterizava-se por um conglomerado de prerrogativas atribuídas ao pater, considerado a autoridade maior do organismo familiar, que dispunha de poderes ilimitados sobre os seus descendentes (poder de vida ou morte). Esses poderes espalhavam-se por dois campos: o pessoal e o patrimonial. Com efeito, no que tange ao poder sobre a pessoa do filho, o pai dispunha do ius vitae et necis (direito de matar o filho ou expô-lo depois de prévia consulta ao consilium domesticum); do ius exponendi (que consistia no direito de abandono do filho infante); do ius vendendi (referente à possibilidade do pai vender o filho como escravo); e por fim do direito de livrar-se da responsabilidade pelo ato ilícito praticado pelo filho, dando-o in noxan ao lesado. Com relação aos poderes referentes ao patrimônio, a regra que subsistia era a de que tudo que fosse adquirido pelo filho seria transferido para o pater. ${ }^{187}$

É imperioso reconhecer que, essa soberania, exercida pelo pai, possuía a característica da vitaliciedade, sendo, no entanto, extinta em algumas situações da vida, tais como: a emancipação voluntária, a morte ou capitis deminutio do pater ou o alcance do filho a certas dignidades maiores. ${ }^{188}$

Com o passar do tempo, contudo, foram reduzidos os poderes conferidos ao chefe de família. Quanto ao aspecto pessoal, diminuiu-se o extremismo opressivo dos pais ao direito simples de corrigir. Na época de Justiniano, o jus vitae et necis, o direito de exposição e o abandono noxal não passavam de reminiscências históricas. ${ }^{189}$

De acordo com o escólio de Washington de Barros Monteiro, o declínio do absolutismo do patria potestas deveu-se a complexas causas: o fim do culto dos antepassados, o desaparecimento de algumas crenças supersticiosas, o alastramento de um sentimento de simpatia maior com relação aos filhos, a influência religiosa. ${ }^{190}$

\footnotetext{
${ }^{186}$ ROCHA, J. V. Castelo Branco. op. cit., p. 19.

${ }^{187}$ BITTAR FILHO, Carlos Alberto. Pátrio poder: regime jurídico atual. Revista dos Tribunais, Sao Paulo, v. 81, n. 676, p. 79, fev. 1992; KARAM, Munir. op. cit., v. 65, p. 393-394; PEREIRA, Caio Mário da Silva. Instituições de direito civil. 12. ed. Rio de Janeiro: Forense, 2001. v. 5, p. 249-250; LÔBO, Paulo. Direito civil: famílias. São Paulo: Saraiva, 2008. v. 3, p. 270.

${ }^{188}$ PEREIRA, Caio Mário da Silva. Instituições de direito civil, cit., p. 249-250.

${ }^{189}$ MONTEIRO, Washington de Barros. Curso de direito civil: direito de família. 28. ed. São Paulo: Saraiva, 1990. v. 2, p. 275; ROCHA, J. V. Castelo Branco. op. cit., p. 21.

${ }^{190}$ MONTEIRO, Washington de Barros. Curso de direito civil: direito de família, cit., p. 275.
} 
Hodiernamente, o poder familiar elidiu completamente o caráter egoístico de outrora. Sua definição, em razão da influência do cristianismo, é completamente diferente. Expressa-se, o debatido instituto, por meio de um complexo de deveres que tem como fundamento o altruísmo. ${ }^{191}$ Esse conjunto de direitos e deveres, impostos pela norma jurídica, aos genitores, tem como escopo a proteção tanto da pessoa do filhos quanto de seus bens. ${ }^{192}$ No entanto, para o presente estudo, importa analisarmos com mais profundidade os seus aspectos pessoais.

Não obstante, é curial reconhecer que o poder familiar não apenas evoluiu no sentido de conferir esse viés assistencialista aos filhos, como também se desenvolveu, com o passar dos tempos, para conceder às mães os mesmos direitos estabelecidos aos pais para o exercício desse munus.

De fato, até que se chegasse à igualdade plena das relações familiares, o Código Civil de 1916 garantia o exercício do pátrio poder apenas ao marido, uma vez que era o chefe da sociedade conjugal. Somente na ausência do pai é que a mãe poderia exercer o pátrio poder com relação aos filhos. É mister explicitar que, caso a viúva se casasse novamente perderia, por consequência, o exercício do pátrio poder em relação a seus filhos, conquistando-o apenas quando enviuvasse novamente (CC/1916 393). O Estatuto da Mulher Casada (L 4121/1962) garantiu o pátrio poder a ambos os genitores, no entanto, estabeleceu que fosse exercido pelo pai com a colaboração da mulher. Caso houvesse divergência entre os pais, a vontade do genitor prevaleceria restando à mãe apenas socorrer-se ao Poder Judiciário. ${ }^{193}$

Essa situação somente se alterou cabalmente com a promulgação da Constituição Federal de 1988, que conferiu tratamento isonômico a ambos os genitores, concedendolhes iguais direitos e deveres referentes à sociedade conjugal e aos filhos. ${ }^{194}$

Sobreleva ressaltar, ainda, que a evolução do instituto do poder familiar deu-se a partir da fase em que o filho deixa de ser objeto de direito e passa a ser sujeito de direito. ${ }^{195}$ Em razão disso, diz-se que os pais exercem um encargo imposto pela lei no desenvolvimento de seu dever de educar.

\footnotetext{
${ }^{191}$ MONTEIRO, Washington de Barros. Curso de direito civil: direito de família, cit., p. 275.

${ }^{192}$ GRISARD FILHO, Waldyr. op. cit., p. 45.

${ }^{193}$ DIAS, Maria Berenice. op. cit., p. 376.

${ }^{194}$ Id. Ibid., p. 377; GRISARD FILHO, Waldyr. op. cit., p. 45.

${ }^{195}$ DIAS, Maria Berenice. op. cit., p. 377.
} 
Realmente, os interesses da criança e do adolescente devem prevalecer sempre no exercício do poder familiar, ${ }^{196}$ pois para a doutrina da proteção integral são os menores de 18 anos seres considerados em peculiar fase da vida, necessitando, consectariamente, de direitos fundamentais especiais para um melhor desenvolvimento de suas personalidades.

Com o advento do Código Civil de 2002, passa-se de pátrio poder, expressão jurídica permeada pelo elemento despótico, em que o filho era mais visto como um objeto de seus pais ${ }^{197}$ do que uma pessoa humana impregnada de direitos, para poder familiar, vocábulo que apesar de não ser o ideal, na visão de muitos doutrinadores, ${ }^{198}$ surge influenciado pela carga principiológica constitucional que modifica o seu sentido perante o direito de família, ressaltando o seu aspecto instrumental para o alcance da melhor educação dos filhos.

Não se pode olvidar, e é importante que se frise, contudo, que essa estrutura altruística já era reconhecida pela doutrina muito antes da entrada em vigor até mesmo da Constituição de 1988, que estabeleceu a plena isonomia nas relações familiares e consolidou a doutrina da proteção integral. Realmente, o Código Civil de 1916, apesar de

\footnotetext{
${ }^{196}$ Nas lições de Pietro Perlingieri: "O Pátrio Poder dos genitores assume mais uma função educativa que propriamente de gestão patrimonial, e é ofício finalizado à promoção das potencialidades criativas dos filhos... O exercício do Pátrio Poder se concentra exclusivamente no interesse do menor". PERLINGIERI, Pietro. op. cit., p. 258-259. Daniel H. D'Antonio, ao tratar do patria potestad, leciona que: "Las modalidades y vicisitudes a que se encuentra sujeta la máxima institución protectora de la minoridad, se vinculan decididamente con la satisfácion o el debido cumplimiento de aquellas conductas orientadas al logro de tal finalidad, que no es otra que posibilitar el pleno desarollo personal del hijo". D'ANTONIO, Daniel H. Responsabilidad paterna y patria potestad. In: MOSSET ITURRASPE, Jorge; D'ANTONIO, Daniel Hugo; NOVELLINO, Norberto José. Responsabilidad de los padres, tutores y guardadores. Buenos Aires: Rubinzal-Culzoni Editores, 1998. p. 145-146. ${ }^{197}$ Id. Ibid.

${ }^{198}$ GRISARD FILHO, Waldyr. op. cit., p. 42; LÔBO, Paulo. Direito civil: famílias, cit., v. 3, p. 268; GONÇALVES, Carlos Roberto. Direito de família. 13. ed. São Paulo: Saraiva, 2008. v. 2, p. 128; DIAS, Maria Berenice. op. cit., p. 377. Maria Berenice Dias é uma das doutrinadoras, como já referido, que muito critica a expressão poder familiar, dissertando que, não obstante tenha o legislador objetivado atender à igualdade entre homens e mulheres no seio doméstico, não andou bem com a mencionada expressão, vez que se olvidou de retirar dela a palavra poder que não sintetiza com veracidade o seu conteúdo. Realmente, o poder familiar é hodiernamente mais um dever, convertendo-se em um munus. Para ela, a expressão mais adequada seria autoridade parental que inclusive goza de maior simpatia da doutrina. Ainda nesse sentido, vale a pena colacionar o escólio de Maria Clara Sottomayor, para quem: “...rejeitamos, agora, a expressão poder paternal, na medida em que a palavra "poder" significa posse, domínio e hierarquia e, nós defendemos, de acordo com a concepção da família actualmente pressuposta pela Constituição e pelo Código Civil, uma família participativa e democrática, baseada na igualdade entre os seus membros e em deveres mútuos de colaboração... Actualmente, preferimos expressões como "responsabilidade paternal" ou "cuidado paternal", que exprimem uma idéia de compromisso diário dos pais para com as necessidades físicas, emocionais e intelectuais dos filhos". SOTOMAYOR, Maria Clara. op. cit., p. 22.
} 
hierarquizar a família, colocando a mulher em uma situação de subordinação em relação a seu marido, perfilhava essa essência protetora do pátrio poder. ${ }^{199}$

O melhor interesse do menor, como alhures mencionado, se materializa na doutrina da proteção integral, insculpida no artigo 227, da CF, e seus corolários, tais como o princípio do reconhecimento da condição peculiar das crianças e dos adolescentes e o estabelecimento, pelo próprio sistema constitucional, de direitos fundamentais especiais.

Diante dessa linha de entendimento, pode-se conceituar o poder familiar como o instituto jurídico que confere aos genitores direitos e deveres para com seus filhos, durante certo período de suas existências, com o escopo, de forma responsável educá-los, auxiliálos e administrar-lhes os patrimônios.

Deveras, como foi referido, o debatido instituto jurídico evoluiu no tempo, assumindo expressamente a sua atual característica, extremamente protetiva da criança e do adolescente, a partir da previsão da doutrina da proteção integral, ${ }^{200}$ insculpida na Constituição de 1988, em seu artigo 227, caput, e ratificada posteriormente pelo Estatuto da Criança e do Adolescente. ${ }^{201}$

Em suas lições, Maria Helena Diniz aduz que: "O poder familiar pode ser definido como um conjunto de direitos e obrigações, quanto à pessoa e bens do filho menor não emancipado, exercido, em igualdade de condições, por ambos os pais, para que possam

\footnotetext{
${ }^{199}$ Clóvis Bevilaqua, ao comentar o art. 379, do CC/16, aduz que: "Pátrio poder é o complexo dos direitos que a lei confere ao pai, sobre a pessoa e os bens dos filhos. No direito moderno, esse conjunto de direito é apenas tutelar, no sentido de que a sua organização visa mais o interesse do filho, que, por sua idade, necessita de um guia e protetor, do que o interesse do pai, como no antigo direito". BEVILAQUA, Clovis. Código Civil dos Estados Unidos do Brasil. 10. ed. atual. por Achilles Bevilaqua. São Paulo: Livr. Francisco Alves, 1954. v. 2, p. 279.

200“"Antes, a intervenção do Estado na esfera familiar ocorria quando esta falhava na assistência que deveria prestar ao menor. Embora isso ainda possa ocorrer, agora também o Estado pode ser demandado se não prestar ao menor aquilo que lhe é devido na área da saúde e da educação, principalmente. Enfim, com o Estatuto, o menor torna-se sujeito de muitos direitos que não lhe eram conferidos por nosso ordenamento jurídico. Há de se lembrar, por oportuno, a frase de Jean Chesal: "L'enfant est sujet et no objet."... A proteção integral há der ser entendida como aquela que abranja todas as necessidades de um ser humano para o pleno desenvolvimento de sua personalidade." ELIAS, Roberto João. Comentários ao Estatuto da Criança e do Adolescente. 3. ed. São Paulo: Saraiva, 2009. p. 2.

${ }^{201}$ Art. 227. "É dever da família, da sociedade e do Estado assegurar à criança e ao adolescente, com absoluta prioridade, o direito à vida, à saúde, à alimentação, à educação, ao lazer, à profissionalização, à cultura, à dignidade, ao respeito, à liberdade e à convivência familiar e comunitária, além de colocá-los a salvo de toda a forma de negligência, discriminação, exploração, violência crueldade e opressão".
} 
desempenhar os encargos que a norma jurídica lhes impõe, tendo em vista o interesse e a proteção do filho". ${ }^{202}$

Com efeito, a evolução do instituto, em discussão, atingiu um ponto em que o seu sentido jurídico é servir como instrumento necessário para garantir à criança e ao adolescente o desenvolvimento máximo de sua personalidade, respeitando a individualidade de cada ser. ${ }^{203}$

De fato, a Constituição de 1988, no capítulo atinente à família, em seu artigo 229, traz um rol de deveres que devem ser observados pelos pais, enquanto detentores do poder familiar. Consectariamente, de acordo com a redação do referido dispositivo, cabe aos pais: assistir, criar e educar os filhos menores. Vale dizer, também, que esse conjunto de deveres é preconizado tanto pelo Estatuto da Criança e do Adolescente, em seu artigo 22, quanto pelo Código Civil, em seu artigo 1.634.

Como se não bastasse, a própria Carta Magna de 1988, em seu artigo 205, dispôs a respeito do conteúdo e do significado do direito à educação, aduzindo que: "A educação, direito de todos e dever do Estado e da família, será promovida e incentivada com a colaboração da sociedade, visando ao pleno desenvolvimento da pessoa, seu preparo para o exercício da cidadania e sua qualificação para o trabalho". Assim, aos pais cumpre dirigir a criação e educação ${ }^{204}$ dos filhos.

Ana Elizabeth Lapa Wanderley Cavalcanti distingue o dever de criação do dever de educação. A criação é o dever essencial do poder familiar, é a precípua função dos progenitores que implica garantir aos filhos o acesso a todos os direitos fundamentais referentes à pessoa humana. ${ }^{205}$

\footnotetext{
${ }^{202}$ DINIZ, Maria Helena. Curso de direito civil brasileiro: direito de família. 18. ed. São Paulo: Saraiva, 2002. v. 5, p. 447. Roberto De Ruggiero, ao tratar do pátrio poder, assenta que: “...o instituto manifesta-se, como dissemos, como uma relação de proteção destinada a reger os filhos menores, a promover o seu desenvolvimento físico e intelectual, e a salvaguardar os seus interesses materiais e morais". DE RUGGIERO, Roberto. op. cit., v. 2, p. 308.

${ }^{203}$ Ao se referir ao conteúdo do cuidado ou responsabilidade parental, Maria Clara Sottomayor aduz que: "A natureza jurídica do cuidado ou da responsabilidade parental consiste numa função destinada a promover o desenvolvimento, a educação e a protecção dos filhos menores não emancipados". SOTOMAYOR, Maria Clara. op. cit., p. 23.

${ }^{204}$ Paulo Lôbo, ao analisar o dever de educação dos filhos impostos aos detentores do poder familiar, leciona que os pais devem, ao exercê-lo, prepará-los para que aprendam a viver em sociedade. LÔBO, Paulo. Direito civil: famílias, cit., v. 3, p. 276.

${ }^{205}$ CAVALCANTI, Ana Elizabeth Lapa Wanderley. O exercício do poder familiar e a sociedade da informação. In: O direito na sociedade da informação II. São Paulo: Atlas, 2009. p. 92.
} 
Já o dever de educação significa orientar a pessoa, permitindo o desenvolvimento da sua personalidade, concedendo-lhe instrução adequada de forma a prepará-la para o mercado de trabalho, sem descurar, evidentemente, da imprescindível orientação espiritual. $^{206}$

Vale dizer: esses dois deveres assumem várias facetas, que nada mais representam que desdobramentos a serem obrigatoriamente observados. Dessa forma, devem os pais proporcionar, principalmente, o preparo intelectual condizente, matriculando os filhos em estabelecimento de ensino regular e também fornecer-lhes formação moral.

É preciso reconhecer, ainda, que dirigir a criação e educação dos filhos impõe aos pais presença constante perante os filhos, de forma que possa transmitir-lhes valores morais compatíveis com a ideologia dominante, permitindo futuramente a todos uma harmoniosa vida em sociedade. A constante presença responsável dos pais é um fator fundamental no desenvolvimento promissor da personalidade de seus descendentes. Ou seja, os pais devem preparar os filhos para uma vida adulta sadia e em consonância com as expectativas do grupo social. ${ }^{207}$ Deveras, os pais devem empenhar-se na educação dos filhos, exercendo esse munus como se os destinatários finais de seu exercício não fossem apenas seus filhos, mas também a sociedade, que tanto necessita em seu corpo de pessoas diligentes e preocupadas em exercer seus direitos solidariamente. ${ }^{208}$

É dessa maneira que se constrói uma sociedade livre, justa e solidária.

Destarte, pode-se afirmar que a criação dos filhos possui uma finalidade imediata: prepará-los adequadamente à vida adulta repleta de percalços, e mediata: a de salvaguardar, a longo prazo, os interesses sociais para a construção de uma sociedade

\footnotetext{
${ }^{206}$ MACIEL, Kátia Regina Ferreira Lobo Andrade. Curso de direito da criança e do adolescente: aspectos teóricos e práticos. 3. ed. Rio de Janeiro: Lumen Juris, 2008. p. 98.

${ }^{207}$ Carlos Alberto Bittar Filho, quando enumera as prerrogativas dos pais, no exercício do poder familiar quanto à pessoa dos filhos, aduz que no momento em que a legislação civilista impõe aos pais o dever de dirigir-lhes a educação e criação, implicitamente, como fragmentos destes deveres estão inseridas as necessidades de preparar "os filhos para a vida e torna-los úteis à sociedade". BITTAR FILHO, Carlos Alberto. op. cit., p. 81; GRISARD FILHO, Waldyr. op. cit., p. 48.

${ }^{208}$ Jorge Mosset Iturraspe, ao comentar a respeito dos deveres do pais com relação aos seus filhos, sentencia que: "Doctrina y jurisprudencia han insistido, desde antiguo, en que los padres deben: - Educar em el respeto al prójimo...”. MOSSET ITURRASPE, Jorge. La culpa de los padres. In: MOSSET ITURRASPE, Jorge; D'ANTONIO, Daniel Hugo; NOVELLINO, Norberto José. Responsabilidad de los padres, tutores y guardadores. Buenos Aires: Rubinzal-Culzoni Editores, 1998. p. 21. O artigo 29 da Convenção Internacional sobre os Direitos da Criança, em seu art. 29, d, afirma que: "Os Estados partes reconhecem que a educação da criança deverá estar orientada no sentido de:...d) preparar a criança para assumir uma vida responsável numa sociedade livre, com espírito de compreensão, paz, tolerância e igualdade de sexos e amizade entre todos os povos, grupos étnicos, nacionais e religiosos e pessoas de origem indígena".
} 
harmônica com as características ditadas pela Constituição, em seu artigo $3^{\circ}$, I, acima citadas. ${ }^{209}$

Não se pode olvidar que, dessa maneira, estariam sendo observados os objetivos constitucionalmente previstos para o nosso país.

Em inúmeras situações deparamo-nos com atrocidades, cometidas por membros da sociedade, que exteriorizam os reflexos negativos de uma educação individualista, negligente e irresponsável, resultado de uma criação que se esqueceu de transmitir os valores mais elementares, assim como o de impor limites e de doar maior afetividade aos filhos.

Silvano Andrade do Bomfim, em trabalho premiado no $3^{\circ}$ Congresso Paulista de direito de família, realizou uma pesquisa muito interessante e oportuna quanto às consequências nefastas de uma educação deficitária.

Nesse trabalho, que se aborda a questão referente ao Bullying e suas consequências no âmbito da responsabilidade civil, restou claro que a indulgência e a permissividade dos pais no desempenho dos deveres de criação e educação causam sérios prejuízos no desenvolvimento da personalidade dos menores e que, em tempos futuros, poderão ter como resultado a prática de atos prejudiciais ao corpo social.

A pesquisa demonstrou que $60 \%$ dos menores que possuíam histórico de prática de bullying, durante o ensino primário e secundário, antes dos 24 anos de idade, haviam sofrido condenações criminais, sendo que as crianças que corriam maiores riscos de apresentarem comportamento condizente com o bullying, eram aquelas que vinham de lares desajustados do ponto de vista educacional e emocional, em que os pais não apresentavam comportamento satisfatório no dever de bem criar seus filhos. ${ }^{210}$

\footnotetext{
${ }^{209}$ Não é por outro motivo que o art. 205 da CF/88 preconiza que: "A educação, direito de todos e dever do Estado e da família, será promovida e incentivada com a colaboração da sociedade, visando ao pleno desenvolvimento da pessoa, seu preparo para o exercício da cidadania e qualificação para o trabalho." (grifos nossos).

${ }^{210}$ Neste diapasão são suas as palavras: "Nos Estados Unidos da América, segundo dados publicados pelo National youth Violence Prevention Resource Center, estima-se que quase 30\% dos jovens norteamericanos (ou mais de 5,7 milhões) estejam envolvidos de alguma forma com bullying, quer como agentes, quer como vítimas, ou ambos. Segundo a entidade, enquanto a prática de bullying cometida pelos meninos tem como alvo qualquer dos sexos, sendo que quando voltada para outros meninos geralmente envolve agressões físicas, a prática de bullying entre as meninas é diferente, pois, além de ter como alvo, em regra, apenas outras meninas, a forma de agressão é mais sutil e indireta do que a realizada pelos meninos, sendo comumente restrita a fofocas e encorajamento de outras meninas à rejeição e exclusão da
} 
Como é cediço, a nossa Constituição Federal prevê o princípio da paternidade responsável em seu artigo $226, \S 7^{\circ}$, de modo a estabelecer aos pais a necessidade de cuidarem de seus filhos de forma menos individualista e mais pluralista, sempre objetivando cercá-los de valores consonantes com a ética da sociedade.

Para permitir o desenvolvimento da paternidade responsável, o Código Civil, em seu artigo 1.634, enumera o conjunto de direitos e deveres dos pais para com seus filhos. São eles: direito de correção com moderação; ter o filho em sua companhia e sob sua guarda; dar ou negar consentimento para que se casem; dever de representação e assistência dos filhos enquanto absoluta ou relativamente incapazes, respectivamente, nos atos em que forem partes; direito e poder de reclamar o filho de quem ilegalmente o detenha e, por fim, direito dos pais de poderem exigir do filho que lhe preste obediência, respeito e os serviços próprios de sua idade ou condição. Entretanto, é curial esclarecer que esses poderes-deveres de ordem pessoal estão submetidos, no seu exercício, ao controle estatal.

Sobreleva ressaltar que, de acordo com o princípio do melhor interesse da criança e do adolescente, esse rol de direitos e deveres não exaustivo (uma vez que faltou o dever de zelo e amor) dos pais é apenas instrumento para possibilitar o desenvolvimento livre da personalidade das crianças e adolescentes. ${ }^{211}$ Ou seja, deverão ser utilizados sempre na perspectiva do atingimento das melhores condições para os filhos, da mesma forma que os poderes da Administração Pública devem ser implementados como instrumentos utilizados na condição de se atingir melhor o interesse da coletividade. ${ }^{212}$

vítima. Verificou-se ainda haver forte relação entre a prática de bullying pelos juvenis e adolescentes e os posteriores problemas na fase adulta, mostrando um estudo que $60 \%$ dos que praticaram bullying na escola durante o ensino primário e secundário sofreram condenações criminais antes dos 24 anos de idade. Verificou-se ainda que crianças e adolescentes que vêm de lares onde os pais provêm pouco apoio emocional aos filhos, falham em monitorar suas atividades, ou têm pouco envolvimento em suas vidas, correm mais riscos de desenvolver comportamento de bullying. Esse risco também aparece em decorrência da forma de disciplina dos pais, quer seja ela excessivamente permissiva ou extremamente severa." BOMFIM, Silvano Andrade do. Bullying e responsabilidade civil: uma nova visão do direito de família à luz do direito civil constitucional, p. 6. Trabalho premiado no $3^{\circ}$ Congresso do IBDFAM/SP, ocorrido nos dias 27, 28 e 29 de agosto de 2009, na cidade de São Paulo/SP.

${ }^{211}$ LÔBO, Paulo. Direito civil: famílias, cit., v. 3, p. 268.

${ }^{212}$ Hely Lopes Meirelles advoga que: "Para bem atender ao interesse público, a Administração é dotada de poderes administrativos - distintos dos poderes políticos - consentâneos e proporcionais aos encargos que lhe são atribuídos. Tais poderes são verdadeiros instrumentos de trabalho, adequados à realização das tarefas administrativas. Daí o serem considerados poderes instrumentais, diversamente dos poderes políticos, que são estruturais e orgânicos, porque compõem a estrutura do Estado e integram a organização constitucional". MEIRELLES, Hely Lopes. Direito administrativo brasileiro. 24. ed. São Paulo Malheiros Ed., 1999. p. 100. 
Impende explicitar que o poder familiar, exercido a partir do conjunto de deverespoderes assim expressos, é irrenunciável, indelegável e imprescritível, sendo que suas obrigações são personalíssimas. ${ }^{213}$

No que tange ao direito de correção com proporcionalidade, apesar de vozes discordantes quanto a sua legalidade, é mister reconhecer que por meio dessa prerrogativa os pais logram êxito, com maior eficiência, na transmissão da escala de valores necessários para uma vida em sociedade estável.

Não se nega a dificuldade que os pais enfrentam no desenvolvimento desse ofício. ${ }^{214}$ Contudo, considerando que o projeto parental é livre decisão do casal, havendo inclusive vedação legal de intromissão nessa deliberação pelo Estado ou por qualquer ente, cabe a ele sopesar no momento de decidir a respeito de ter ou não filhos os ônus que recairão durante a fase de preparação de seus descendentes para a vida adulta. ${ }^{215}$

No entanto, é interessante verificar que, hoje, em dia, a sociedade tem assistido a uma mudança muito grande na forma de educação dos filhos. ${ }^{216}$ Essa alteração tem trazido reflexos negativos para o corpo social, porquanto quotidianamente tem-se a notícia de que a violência infanto-juvenil tem crescido demasiadamente.

${ }^{213}$ GONÇALVES,Carlos Roberto. Direito de família, cit., v. 2, p. 128.

${ }^{214}$ “São, sobretudo, os filhos que marcam a passagem da família da esfera privada para a esfera social. Com os filhos, o casal conjugal torna-se também casal parental e às identidades de homem e mulher agregam-se as de pai e mãe, com todo peso e expectativas individuais e sociais carreadas por estas funções. Com os filhos, modifica-se a permeabilidade da fronteira familiar, havendo maior intercâmbio com o meio social, e também controle por arte da sociedade. As crianças, que há um tempo praticamente pertenciam aos pais, ou melhor, ao pai, passaram paulatinamente a ser considerados em sua individualidade - sujeitos de direitos objetivos e subjetivos, e a serem passíveis de proteção do Estado. Esta mudança contou com a contribuição relativamente recente do conhecimento trazido pela Psicologia e Psicanálise". GROENINGA, Gisele Câmara. Guarda compartilhada: a efetividade do poder familiar. In: COLTRO, Antonio Carlos Mathias; DELGADO, Mario (Coords.). Guarda compartilhada. São Paulo: Método, 2009. p. 151-152.

${ }^{215}$ A Constituição Federal de 1988 assevera, em seu art. 226, § $7^{\circ}$, que: "Fundado nos princípios da dignidade da pessoa humana e da paternidade responsável, o planejamento familiar é livre decisão do casal, competindo ao Estado propiciar recursos educacionais e científicos para o exercício desse direito, vedada qualquer forma coercitiva por parte de instituições oficiais ou privadas." (grifos nossos).

De acordo com o art. 1.513 do Código Civil: "É defeso a qualquer pessoa, de direito público ou privado, interferir na comunhão de vida instituída pela família."

${ }^{216}$ Jean-Pierre Lebrun, em entrevista nas páginas amarelas da revista veja, de 9 de dezembro de 2009, assevera que o comportamento das famílias tem-se modificado ao longo do tempo e exemplifica da seguinte forma: "A mudança é visível. Na Europa, por exemplo, quando um professor dá nota baixa ao aluno, é certo que os pais vão aparecer na escola no dia seguinte para reclamar com ele. Há vinte ou trinta anos era o aluno que tinha de dar satisfações aos pais diante do professor. É uma completa inversão. Posso citar outro exemplo. Desde sempre, quando se levam os filhos pela primeira vez à escola, eles choram. Hoje em dia, normalmente são os pais que choram. A cena é comum. É como se esses pais continuassem crianças. Isso acontece porque eles não são capazes de se apresentar como a geração acima da dos filhos. É uma consequência desse novo arranjo social, em que os papéis estão organizados de forma mais horizontal”. LEBRUN, Jean-Pierre. Entrevista. Veja, São Paulo, ano 12, n. 49, ed. 2142, 09 dez. 2009. 
Impende reconhecer que o incremento da prática de bullying tem axiomática relação com as mudanças sociais das últimas décadas. As brincadeiras de hoje, basicamente constituídas de jogos eletrônicos, são solitárias e têm um apelo para a violência, diferentemente das formas de divertimento do passado com pipas, quebracabeças, carrinhos de rolimã que promoviam a sociabilidade das crianças e adolescentes que brincavam ao ar livre. A isso se deve somar a exposição das crianças a uma televisão que a todo o instante traz cenas de violência. Ademais, a necessidade de trabalho de ambos os genitores dificulta o convívio com a prole, o que acarreta uma educação desprovida da transmissão de valores morais, éticos e cívicos, gerando um número significativo de crianças e adolescentes sem limites, o que aumenta a prática do bullying. ${ }^{217}$

Assim, essa maneira permissiva e muito liberal de se criar os filhos não condiz com os preceitos legais e, principalmente, constitucionais no que tange ao dever de educar os filhos de forma a prepará-los para a vida adulta. A não imposição de limites aos infantes tem ocasionado, indubitavelmente, transtornos na personalidade desses seres em condição peculiar de desenvolvimento, que muito tem preocupado Educadores e Psicólogos. ${ }^{218}$ Ou seja, há uma evidente crise de autoridade e de presença dos pais na vida dos filhos, o que

\footnotetext{
${ }^{217}$ BOMFIM, Silvano Andrade do. op. cit., p. 8.

${ }^{218}$ Jean-Pierre Lebrun, em entrevista nas páginas amarelas da revista veja, de 9 de dezembro de 2009, aduz que: "Hoje os pais precisam discutir tudo, negociar o que antes eram ordens definitivas. E isso não é necessariamente algo negativo, desde que fique claro que, depois de negociar, discutir, trocar idéias, quem decide sãos os pais”. LEBRUN, Jean-Pierre. op. cit. Laísa Weber Prust e Paula Inez Cunha Gomide, em interessante artigo publicado em revista especializada, asseveram que: "A dinâmica do grupo familiar é muito poderosa no processo de desenvolvimento da criança, pois é em casa que adquirirá quase todos os repertórios comportamentais básicos. Pais sensíveis, responsivos e pró-sociais exercem forte influência no desenvolvimento do senso de cooperação e reciprocidade das crianças despertando expectativas positivas sobre a disposição dos outros para dar e receber ajudas (Koller \& Bernardes, 1997). Pode-se a firmar que os pais e cuidadores representam a primeira e maior fonte de reforçamento e modelo para os filho...Estudos empíricos têm corroborado a relação entre os estilos parentais e o comportamento moral. Diferenças entre a qualidade da relação afetuosa entre os pais e as práticas parentais disciplinares têm sido associadas com a sofisticação de raciocínio moral de crianças (Dunn, Brown \& Maguire, 1995). Pesquisadores encontraram correlação positiva entre comportamento pró-social de crianças e práticas maternas de educação voltadas para o desenvolvimento da empatia (Eisenberg et al., 1993). Outros estudos apontam menor vulnerabilidade ao uso de drogas em adolescentes apegados à figura, lar cujo ambiente é saudável, aceitação de crenças sobre o bom comportamento e desaprovação paterna específica a certos comportamentos (Nurco \& Lerner, 1996). Patterson, Reid e Dishion (1992) apontam o uso apropriado de reforçamento positivo, a habilidade para resolver problemas de grupo, a supervisão e a monitoria dos pais como importantes fatores relacionados à pró-sociabilidade. Por meio de estudo empírico, Wright e Cullen (2001) confirmaram os resultados de pesquisas anteriores que indicavam que o controle desempenha papel central para a etiologia de comportamentos anti-sociais. Práticas parentais como supervisão, estabelecimentos de limites, posicionamentos claros em relação a regras e relacionamento estreito entre os membros da família podem reduzir a possibilidade de engajamento em comportamentos de risco..." PRUST, Laísa Weber; GOMIDE, Paula Inez Cunha. Relação entre comportamento moral dos pais e dos filhos adolescentes. Scielo Brazil. Disponível em: <http://www.scielo.br/scielo.php?script=sci_arttext\&pid=S0103166X2007000100006\&lng=en\&nrm=iso\&tlng=pt>. Acesso em: 04 jan. 2011.
} 
contribui, de acordo com profissionais da saúde mental, para um aumento na prática de condutas antissociais por parte das crianças e adolescentes. ${ }^{219}$

Comentando sobre a problemática na questão da exigência de obediência e respeito dos filhos para com seus genitores, Caio Mário aduz que: "Não falta, na literatura geral ou especializada, menção ao que se tem chamado de crise da autoridade em que se proclama a rebeldia dos filhos contra os pais. O problema parece mais uma deficiência da compreensão paterna. Os métodos pedagógicos mudaram, as relações com a geração nova assumiram aspecto diferente e, obviamente, o tratamento dispensado aos filhos in potestate há que se desprender das características de antanho".220

É curial esclarecer que a família contemporânea sofreu mutação nuclear em sua estrutura que propicia essa dificuldade aos genitores de despenderem mais tempo para seus filhos, de forma a nutri-los de maiores valores ético-morais e condicioná-los, por conseguinte, a uma vida consciente no que se refere ao conceito de cidadania, em sentido amplo, ou seja, aos seus direitos e deveres como cidadãos.

Os pais devem trabalhar e, logo no início da vida de seus filhos (por vezes com poucos meses de idade) são obrigados a deixá-los em "escolinhas" para que lá recebam cuidados, impossibilitando a necessária convivência com eles.

A criação e educação é algo sério e exige dedicação por parte dos genitores, sob pena de lançarem na sociedade pessoas individualistas, egoístas e despreparadas para a cessão e limitação de suas liberdades em prol da comunidade.

A partir desse cenário e de tudo que foi exposto alhures, chega-se facilmente à conclusão de que a autonomia da família sofre, em alguns aspectos, interferência do poder estatal que tem como escopo principal garantir a adequada assistência e educação das crianças e adolescentes. Ainda recentemente, o Presidente da República enviou ao Congresso Nacional projeto de lei alterando o Estatuto da Criança e do Adolescente

\footnotetext{
${ }^{219}$ A Psicanalista, Gisele Câmara Groeninga, ao dissertar a respeito da guarda compartilhada e seus benefícios afirma que: "Impossível desconhecer a realidade de que um grande número de lares em nosso país é composto somente pela mãe e filhos, e que este arranjo familiar cresce de forma exponencial; impossível desconhecer a crise de autoridade presente nas relações familiares e sociais; necessário saber que as estatísticas apontam para uma alta correlação entre o consumo de drogas e a ausência paterna, e que é numericamente significativa a falta do nome do pai nas certidões de nascimento de encarcerados. Parece que deixamos de atribuir tudo "à culpa da mãe"... (se bem que é verdade que, na inexorável complementaridade das relações cabe a ela sua parcela de responsabilidade no reconhecer e referendar o pai)". GROENINGA, Gisele Câmara. op. cit., p. 159.

${ }^{220}$ PEREIRA, Caio Mário da Silva. Instituições de direito civil, cit., p. 256.
} 
(ECA), para proibir toda forma de punição violenta às crianças, desconsiderando o fato de que educar é a melhor forma de proteger e que, às vezes, as crianças precisam ser contidas fisicamente.

Tamanha é a importância do desempenho do poder familiar de modo satisfatório e com responsabilidade, que o Código Penal traz dois tipos penais que visam tutelar a vida e a educação dos filhos, sendo que um deles incrimina a conduta dos pais que deixam, imotivadamente, de pagar alimentos, tipificando o crime de abandono material previsto no artigo 244, do Código Penal, e o outro o delito de abandono intelectual, preconizado no artigo 246 do mesmo codex.

Vale a pena recordar, ainda, que o artigo 249, do Estatuto da Criança e do Adolescente prevê uma infração administrativa, no caso de inadimplemento dos pais de proverem a educação dos filhos.

Dessa forma, se os pais falham em seu dever de bem educar ${ }^{221}$ os seus filhos, contrariando dispositivo constitucional e infra-constitucional, de forma a não nutri-los de valores éticos suficientes para que se tornem pessoas responsáveis e conscientes de seus deveres de cidadania, no sentido lato, deve recair sobre eles uma reprimenda jurídica.

É a expressão da lógica do sistema que requer, para a escorreita observância e respeito das suas normas jurídicas, a aplicação da sanção em caso de contrariedade aos seus preceitos de maneira a dar eficácia necessária ao ordenamento. Dessa forma, a perda ou destituição do poder familiar, quando há negligência grave no desempenho desse mister, é uma sanção insuficiente para tutelar, em todos os seus desdobramentos, as consequências jurídicas negativas do fracasso educacional.

Impende considerar que a busca da responsabilidade civil dos pais, nas condições aqui defendidas, deve ser o resultado de uma somatória de circunstâncias que, sinteticamente, podem ser enumeradas na deficiente educação fornecida aos filhos ao

\footnotetext{
${ }^{221}$ De acordo com os ensinamentos de J.V. Castelo Branco Rocha: "Criação e educação constituem o atendimento das necessidades materiais e morais do menor. Criar significa manter, sustentar, alimentar, dar enfim ao indivíduo as condições necessárias à sobrevivência. Na criação estão compreendidos os cuidados relativos à saúde, segurança e moralidade. A tarefa de criar já compreende o dever de educar, visto que a criação de um ser humano subentende, necessariamente, a sua educação... Mas acontece que o legislador preferiu referir-se, destacadamente, à criação e educação. Fala do dever de criar e educar os filhos, dando a entender que se trata de assuntos, que envolvem conceitos diferentes. Isto posto, é admissível dizer que criar os filhos é atender às necessidades do ser humano, na sua expressão biológica. Educá-los é levar em conta o intelecto, o caráter e a personalidade.” ROCHA, J. V. Castelo Branco. op. cit., p. 143-144.
} 
longo de sua existência, somada à causação de um dano indenizável por eles quando, embora maiores de idade, vivam sob a dependência econômica de seus genitores que, indubitavelmente, nessa situação, oportunizarão a ocorrência do prejuízo ocasionado a outrem.

A eventual falha dos pais no dever de bem educar e criar os filhos não pode ser desconsiderada pelo sistema, mesmo após o alcance da plena maioridade dos descendentes de primeiro grau se os genitores são complacentes em arcar com o sustento deles, ou seja, se permitem que não trabalhem e vivam às suas custas. A sociedade, já tão combalida com tamanha violência que assola o país, não pode ser obrigada a suportar mais esse ônus, isto é, ter que aceitar irresignada práticas de atos ilícitos praticados por jovens, maiores de 18 anos, que vivem sob a dependência econômica de seus pais, sem poder ver ressarcido, seja pelo jovem ou por seu genitor, o dano que aquele tenha causado a outrem.

Essa nova maneira, arrojada, de se pensar o instituto da responsabilidade civil dos pais, alargando a sua hipótese de incidência, nada mais representa que uma preocupação maior do sistema com a vítima e com a necessária assunção de maiores responsabilidades, por parte dos genitores, nos seus deveres de criação e educação. ${ }^{222}$

Com efeito, Giselda Maria Fernandes Novaes Hironaka desenvolveu o instituto da responsabilidade pressuposta que, de alguma forma, fortalece, de acordo com nossa visão, o pensamento já expresso, mormente com relação à preocupação mais específica com a vítima que deve figurar sempre no centro das discussões e preocupações, pois sua indenização é imperiosa. Propõe-se, assim, uma nova visualização da responsabilidade

\footnotetext{
${ }^{222} \mathrm{O}$ art. 19, do ECA, aduz que: "Toda a criança ou adolescente tem direito a ser criado e educado no seio de sua família e, excepcionalmente, em família substituta, assegurada a convivência familiar e comunitária, em ambiente livre da presença de pessoas dependentes de substâncias entorpecentes". Em comentários ao referido artigo, Maria do Rosário Leite Cintra escreve que: "Realmente, a família é condição indispensável para que a vida se desenvolva, para que a alimentação seja assimilada pelo organismo e a saúde se manifeste. Desabrochar para o mundo inclui um movimento de dentro para fora, o que é garantido pelos impulsos vitais vinculados à hereditariedade e à energia próprias do ser vivo. Mas este movimento será potenciado ou diminuído, e até mesmo obstaculizado, pelas condições: $60 \%$, dizem os entendidos, são garantidos pelo ambiente. Não basta pôr um ser humano biológico no mundo, é fundamental complementar a sua criação com a ambiência, o aconchego, o carinho e o afeto indispensáveis ao ser humano, sem o que qualquer alimentação, medicamento ou cuidado se torna ineficaz. O ideal é que os filhos sejam planejados e desejados por seus pais e que estes possam garantir-lhes a sobrevivência nas condições adequadas. É fundamental, pois, que os adultos que geraram a criança a assumam e adotem. A família é o lugar normal e natural de se efetuar a educação, de se aprender o uso adequado da liberdade, e onde há a iniciação gradativa no mundo do trabalho. É onde o ser humano em desenvolvimento se sente protegido e de onde ele é lançado para a sociedade e para o universo." CURY, Munir; SILVA, Antônio Fernando do Amaral; MENDEZ, Emílio García. Estatuto da Criança e do Adolescente comentado. 5. ed. São Paulo: Malheiros Ed., 2002. p. 85.
} 
civil para além da culpa (responsabilidade subjetiva) ou da existência de riscos (responsabilidade objetiva). ${ }^{223}$

Essa assertiva é reforçada a partir do instante em que se reconhece que o ser humano passa a ocupar o centro do sistema, e o direito patrimonial cede espaço em virtude do princípio da dignidade da pessoa humana insculpido no art. $1^{\circ}$, III, da nossa Lei Suprema. $^{224}$

Deveras, em sua tese de livre docência, a eminente professora propõe uma nova visualização da responsabilidade civil para além da culpa (responsabilidade subjetiva) ou da existência de riscos (responsabilidade objetiva).

Neste momento, vale a pena trazer à baila os ensinamentos de Gustavo Tepedino para quem: "Os preceitos ganham, contudo, algum significado se interpretados com especificação analítica da cláusula geral de tutela da pessoa humana prevista no texto constitucional no art. $1^{\circ}$, III (a dignidade como valor fundamental da República). A partir daí, deverá o intérprete afastar-se da ótica tipificadora seguida pelo Código Civil, ampliando a tutela da pessoa humana não apenas no sentido de contemplar novas hipóteses de ressarcimento, mas, em perspectiva inteiramente diversa, no intuito de promover a tutela da personalidade mesmo fora do rol de direitos subjetivos previstos pelo legislador codificado". 225

${ }^{223}$ HIRONAKA, Giselda Maria Fernandes Novaes. Responsabilidade pressuposta. Belo Horizonte: Del Rey, 2005.

${ }^{224}$ Art. 1. ${ }^{\circ}$ A República Federativa do Brasil, formada pela união indissolúvel dos Estados e Municípios e do Distrito Federal, constitui-se em Estado Democrático de Direito e tem como fundamentos: III-a dignidade da pessoa humana."

${ }^{225}$ TEPEDINO, Gustavo. A tutela da personalidade no ordenamento civil-constitucional brasileiro. In: . Temas de direito civil. Rio de Janeiro: Renovar, 2004. p.27. 


\section{MUDANÇAS NA ESTRUTURA DAS FAMÍLIAS BRASILEIRAS E NAS FONTES DO DIREITO PÁTRIO}

A vida em sociedade é repleta de dinamismo, criatividade e inventividade do homem que, não rara vez, impede a legislação de acompanhar pari passu todas essas transformações em virtude da rapidez com que ocorrem. ${ }^{226}$

A organização familiar também se modificou ao longo dos anos, eclodindo uma estruturação nova que se resume, mormente, na saída tardia dos filhos do domicílio de seus genitores. $^{227}$

Como se não bastasse, muitas vezes, os filhos vivem em situação de plena dependência econômica de seus pais ou, mesmo que não compartilhem o mesmo teto, permanecem nele por muitos anos, após o atingimento da plena capacidade civil, destituídos de economia própria, capaz de conceder-lhes cabal e real independência para os anseios da vida.

A necessidade de preparação para o acirrado mercado de trabalho, cada vez mais exigente, contribui para a sujeição econômica dos filhos em relação a seus pais durante o período universitário que, normalmente, tem uma duração de 4 a 5 anos, mesmo após a cessação da menoridade civil.

Nesse período, o filho pode não possuir patrimônio próprio e depende, consequentemente, da idoneidade financeira de seus genitores para a sua subsistência e conforto na vida. Assim como ocorria, guardadas as devidas proporções, no período do pater familias do direito romano.

Naquela época, como já relatado, o poder parental prolongava-se indefinidamente na pessoa do pai, qualquer que fosse a idade do filho, pois este não podia ter patrimônio

\footnotetext{
${ }^{226}$ GROENINGA, Gisele Câmara. op. cit., p. 150.

${ }^{227}$ O Programa Fantástico, da rede Globo, no dia 21/02/2010, veiculou uma pesquisa da Latin Panel cujo conteúdo era o seguinte: "No Brasil, filhos de famílias com boas condições financeiras ficam por mais tempo sob o teto dos pais. Com efeito, no nosso país, filhos de famílias com boa condição financeira -com renda acima de $\mathrm{R} \$ 9.000,00$ (nove mil reais) aproveitam a situação para ficar em casa. Na faixa estaria de 25 a 29 anos, 62\% continuam morando com os pais. Na faixa etária de 30 a 34 anos são $30 \%$. E de 35 a 39 anos, 15\%. Em 2003, uma pesquisa do governo italiano ouviu dez mil pessoas entre 18 a 39 anos que moravam com os pais. Quatro anos depois 79\% não tinham saído de casa. Na Alemanha, 29\% dos jovens até 25 anos continuam com os pais. Na mesma situação, na Inglaterra, são 29\% dos homens e 18\% das mulheres entre 20 e 34 anos."
} 
próprio, separado do patrimônio do pai. Como decorrência lógica dessa estrutura familiar, o pai respondia civilmente pelos danos ocasionados pelos seus filhos.

De acordo com essa realidade contemporânea, em que os filhos dependem economicamente de seus genitores, ainda que alguns anos após a cessação da incapacidade civil, é mister considerar que qualquer ato ilícito por eles praticados, causando prejuízo a outrem, ressentiria de adequada resposta por parte do Estado, junto à vítima, em termos indenizatórios, considerando os preceitos normativos e a interpretação jurisprudencial ${ }^{228}$ dessa matéria na atualidade.

A vítima, caso seja feita uma leitura simplista e interpretação estritamente gramatical do instituto da responsabilidade civil para a circunstância em tela, não terá onde se socorrer para tornar indene a sua esfera de direitos, porquanto o seu ofensor, geralmente, não tem patrimônio próprio.

O tema, hodiernamente, tem importância prática, conquanto a imprensa constantemente veicule informações a respeito de jovens de classe média que vivem sob a dependência econômica de seus pais, apesar da plena capacidade e praticam ilícitos causando prejuízo a outrem.

De fato, de acordo com essa situação, não poderão indenizar os danos morais e patrimoniais advindos diretamente de seus atos, porquanto a responsabilidade é patrimonial e, geralmente, nada possuem, deixando, dessa maneira, a vítima impossibilitada de buscar a reparação colimada de acordo com a atual interpretação da matéria pela doutrina e jurisprudência brasileiras.

Outro fator, já relatado, que contribuiu para o surgimento da situação fática descrita, foi a diminuição da faixa etária para a aquisição da plena capacidade de direito da pessoa, com o advento do novo Código Civil que, em seu artigo $5^{\circ}$, condicionou a capacidade de fato ao atingimento do $18^{\circ}$ aniversário da pessoa natural.

Destarte, considerando as condições financeiras das famílias e o desdobramento natural da vida desses jovens até o complemento dos estudos, depara-se com uma maior

\footnotetext{
228،Agravo de instrumento. Acidente de veículo. Indenização. Genitora do suposto agente causador do evento danoso. Filho maior. Responsabilidade civil. Inexistência. Artigo 1.521, I, do CC de 1916, com redação atual dada pelo artigo 932, I, do CC de 2002. Inaplicabilidade. Ilegitimidade passiva 'ad causan' da genitora. Reconhecimento. Extinção do processo sem julgamento de mérito. Exegese do artigo 267, VI, do CPC. Recurso provido”. (TJSP - AI no 897.955-0/6, rel. Rocha de Souza - 32ª Câmara Cível).
} 
convivência onerada dos pais para com seus filhos que, não obstante a plena capacidade deles, dependem completamente dos seus genitores para a sua formação e subsistência.

No entanto, a ruptura jurídica do vínculo que liga pais e filhos, após o alcance da idade de 18 anos, não tem o condão de significar a irresponsabilidade dos pais pela vida e subsistência de seus filhos de maneira absoluta.

Deveras, o ordenamento jurídico, visualizado de uma forma ampla, abarcando todas as suas fontes, prevê obrigações legais aos pais que não derivam imediatamente do texto normativo, levando-nos à conclusão de que o sistema não confere aos filhos a total desvinculação de seus pais com a maioridade. Assim, não se pode olvidar que a jurisprudência é fonte formal mediata do direito, possuindo um enorme poder de persuasão sobre o intérprete.

Com efeito, mesmo após superar a idade de 18 anos, o sistema jurídico pátrio, em algumas circunstâncias, presume a necessidade de proteção especial aos filhos e impõe o consequente dever dos pais de prestarem pensão alimentícia, mesmo que não paire nenhuma impossibilidade física, aprioristicamente, que impeça o beneficiado de conseguir, por sua própria força, manter a sua subsistência. Ou seja, o sistema, como um todo, alberga uma proteção especial aos filhos por algum tempo mesmo após o atingimento da plena capacidade.

Nessa mesma ordem de idéias, o fato de o jovem completar a idade de 18 anos, que é a questão que nos interessa, não lhe retira toda a tutela assistencial a ele outorgada pela ordem jurídica, vez que esta continua a reconhecer, durante um razoável período de tempo, a imperiosa necessidade de conferir-lhe proteção especial em razão de peculiaridades que lhe são próprias.

Neste diapasão, a lei $\mathrm{n}^{\circ} 8112 / 90$ prevê, em seu artigo 217, II, $a$, a possibilidade de o filho continuar a receber a pensão, mesmo após a aquisição da maioridade, até os 21 anos de idade. Contudo, a jurisprudência já tem decidido que a pensão deve continuar até os 24 anos, de forma a possibilitar a conclusão dos estudos da pessoa. ${ }^{229}$

\footnotetext{
${ }^{229}$ Previdenciário. Agravo de Instrumento. Pensão de ex-segurado. Menor sob a guarda à época da concessão. Beneficiária com 21 (vinte e um anos) anos. Estudante Universitária. Vínculo de dependência. Presunção manutenção do benefício. Hipótese na qual se busca provimento que garanta à agravada, beneficiária de pensão por morte, o não cancelamento da mesma face a chegada da maioridade e sua manutenção até os 24 (vinte e quatro) anos por ser estudante universitária; Não dispondo a beneficiária de qualquer outro
} 
É preciso dizer o seguinte: quando a maioridade é atingida, geralmente o jovem está terminando o ensino médio ou começando o ensino superior ou até mesmo dando os primeiros passos em uma profissão. Entretanto a lei, de acordo com o atual ordenamento civilista, proporciona-lhe independência legal, o que não significa que no caso concreto não mais haja uma forte vinculação econômica e moral perante seus pais. Os filhos podem, então, como supracitado, inclusive pleitear pensão alimentícia a seus genitores. ${ }^{230}$

Trata-se, em realidade, de uma prorrogação ${ }^{231}$ do já afirmado dever de educação, inerente ao poder familiar, previsto tanto em sede constitucional quanto infraconstitucional, que reforça a idéia aqui defendida de que não é o simples atingimento da idade legal de 18 anos que confere ao jovem adulto a sua independência perante seus progenitores. Se há prolongamento do dever de educar, impende destacar que essa extensão não pode vir desacompanhada da necessária responsabilidade dos genitores, porquanto continuam presentes na relação paterno filial, elementos da autoridade parental.

De fato, a responsabilidade dos pais pelos atos ilícitos praticados pelos filhos menores é decorrência do poder familiar, devendo ser julgada em razão desse dever. ${ }^{232}$

Realmente, o STJ já definiu que o pai fica obrigado a prestar alimentos ao filho até os 24 anos de idade, desde que esse descendente continue num ciclo de estudo ao alcançar

rendimento, e observando-se o caráter alimentício da pensão previdenciária, há de prevalecer o entendimento segundo o qual a mesma seria mantida enquanto presumida a subsistência do vínculo de dependência até a conclusão dos estudos universitários da dependente. Agravo improvido". (TRF da $5^{\text {a }}$ Região, $2^{\mathrm{a}}$ Turma, AG 27873-CE, $\mathrm{n}^{\mathrm{o}}$ de origem 200005000053092, DJ data 22.06.2001, relator Desembargador Federal Petrúciu Ferreira. Previdenciário. Pensão por morte. Dependente. Estudante. Manutenção do Benefício. 1. A pensão por morte pode ser prorrogada até o beneficiário completar integralmente 24 anos de idade se estiver cursando ensino superior, porquanto não se mostra razoável interromper o seu desenvolvimento pessoal e a sua qualificação profissional. Precedente da $6^{\mathrm{a}}$ Turma desta Corte. Hipótese em que o pagamento do benefício deverá ser mantido somente enquanto a pensionista estiver freqüentado o curso, bem como deverá cessar quando ela completar integralmente 24 anos de idade, ou seja, até o dia anterior à data em que completar os 25 anos. (TRF da $4^{a}$ Região, Agravo de instrumento $\mathrm{n}^{\circ}$ 200404010037750-RS, Relator Juiz Álvaro Eduardo Junqueira, Quinta Turma, unânime, julgado em 25.05.2004, DJ de 07.07.2004.

${ }^{230}$ Neste sentido, a Juíza de Zaragoza Maria Ángeles Callizo Lópes, ao tratar da pensão alimentícia para os filhos maiores de idade, assentou: "En nuestra sociedad actual se constata un incremento de las obligaciones de los padres respecto de los hijos mayores de edad, dado que el mero hecho objetivo de alcanzar la mayoría de edad no es garantía de una independencia económica de los mismos, pues siguen inmersos en sus estudios - realización de una carrera universitaria, máster, preparación de oposiciones, y demás cursos de formación complementaria- orientados a su capacitación profesional, y viviendo 'con' o 'de' los progenitores, produciéndose así una desconexión entre la mayoría de edad civil y aquella em que obtienen lo que se há denominado por la doctrina y jurisprudencia 'mayoría económica'”. CALLIZO LÓPES, Maria Ángeles. op. cit., p. 63.

${ }^{231}$ MACIEL, Kátia Regina Ferreira Lobo Andrade. op. cit., p. 98.

${ }^{232}$ DIAS, José de Aguiar. Da responsabilidade civil. 9. ed. Rio de Janeiro: Revista Forense, 1944. v. 2, p. 512-513. 
a maioridade. Trata-se da Súmula $n^{\circ} .358$ que aduz: "o cancelamento de pensão alimentícia de filho que atingiu a maioridade está sujeito à decisão judicial, mediante o contraditório, ainda que nos próprios autos".

Insta esclarecer que esse prolongamento da obrigação dos progenitores de prestar alimentos aos filhos, já maiores de idade, é uma tendência que se revela inclusive em outros países. 233

Sobreleva ressaltar que o Direito deve sempre se preocupar com as injustiças sociais para que possa atingir as suas finalidades essenciais.

Destarte, cada vez mais a regra dos institutos absolutos vai se coadunando com as peculiaridades de cada caso, porquanto as normas jurídicas devem ser interpretadas de acordo com a realidade social, ${ }^{234}$ o que impõe, por conseguinte, uma flexibilização maior dos preceitos jurídicos em homenagem aos valores irradiados pela Constituição Federal, mormente o valor consubstanciado pelo princípio da solidariedade social que muito acrescentará ao instituto da responsabilidade civil.

Com efeito, nas lições de Stefano Rodotà, o princípio da solidariedade social tem como objetivo colocar o lesado no centro da discussão da responsabilidade civil, desviando o foco de análise da pessoa do causador do dano para a vítima, assegurando a esta última o máximo de indenização. ${ }^{235}$

Não se relegue ao olvido o fato de que a Lei de Introdução ao Código Civil, em seu art. $5^{\circ}$, traz regra interpretativa extremamente importante que, não rara vez, é esquecida pelo intérprete. Assim, a referida norma estabelece que, na aplicação do direito, deve o juiz atender aos fins sociais a que a lei se dirige e às exigências do bem comum. ${ }^{236}$ É imperioso reconhecer que trata esse artigo de critério teleológico na interpretação do direito, que deve sempre buscar a sua finalidade social.

\footnotetext{
${ }^{233}$ A Juíza Maria Ángeles Callizo López, ao tratar das mudanças legislativas atinentes à pensão alimentícia em Zaragoza, que a estendeu aos filhos maiores até a idade de 26 anos, assevera que: "El mero hecho de que un hijo alcance la mayoría edad no supone de forma inminente la cesación de la obligación de los padres de sufragar los gastos de aquél, ya que el artículo 66 de la ley Aragonesa, en armonía con lo establecido en el artículo 39.3 de la CE y en 93.2 y 142 y ss, del Código Civil, mantiene la necessidad de asignación de alimentos para los hijos que aún siendo mayores de edad carecieren de recursos propios y no hubieren completado su formación profesional". CALLIZO LÓPES, Maria Ángeles. op. cit., p. 83.

${ }^{234}$ CALLIZO LÓPES, Maria Ángeles. op. cit., p. 68-69.

${ }^{235}$ Apud LOPEZ, Teresa Ancona. Princípio da precaução e evolução da responsabilidade civil. São Paulo: Quartier Latin, 2010. p. 46.

${ }^{236}$ Decreto-Lei ${ }^{\circ} 4.657$, de 4 de setembro de 1942. Art. $5^{\circ} \mathrm{Na}$ aplicação da lei, o juiz atenderá aos fins sociais a que ela se dirige e às exigências do bem comum.
} 
Assim, pode-se asseverar o seguinte: um pai que, muitas vezes, assente na condição de seu filho não trabalhar e apenas estudar, mesmo após a aquisição da maioridade, deve assumir o risco de indenizar prováveis vítimas de atos lesivos de seu descendente, que depende dele economicamente, mormente quando facilite de alguma forma, a prática do ato danoso. Nessa condição, permitir-se-ia, como será visto, a extensão interpretativa do dispositivo que trata da responsabilidade por fato de terceiro (art. 932 do CC), máxime em razão da necessidade de se perscrutar o sentido da norma contextualizada no ordenamento jurídico como um todo. ${ }^{237}$

Então, não se pode esquecer de que há uma relação direta entre poder e responsabilidade: a responsabilidade será maior na medida em que o poder aumenta. $\mathrm{O}$ nosso Código Civil é pródigo ao prever várias situações de responsabilidade, fundamentadas no poder, como a responsabilidade aqui debatida dos pais pelos atos de seus filhos, a responsabilização do empregador pelos atos danosos de seus empregados (poder de direção, fiscalização e disciplina), etc. ${ }^{238}$

É importante explicitar e reiterar que não há regras absolutas no sistema jurídico, porque não existem fundamentos absolutos e, por conseguinte, direitos absolutos. ${ }^{239} \mathrm{O}$ término do poder familiar com a maioridade dos filhos não pode ter, portanto, o condão de desvincular absolutamente os pais, nas circunstâncias supracitadas, de eventualmente ter a obrigação de indenizar os danos que seus filhos maiores ocasionem a terceiros.

Bobbio discutiu a respeito dos fundamentos absolutos dos direitos do homem, questionando a característica e a possibilidade desse absolutismo e se é ele desejável. Teria ele desenvolvido a idéia de que os direitos ou são positivados ou são aqueles que se gostaria de ter e, nesse caso, a busca de seu fundamento se dá pela argumentação jurídica, tornando-se, a partir daí, norma no sistema positivo. O fundamento geralmente corre a favor dos direitos, de forma que exerce o inquestionável papel de explicar a existência de

\footnotetext{
237،....podemos dizer que não foi possível dar uma definição do direito assumindo o ponto de vista da norma jurídica, isoladamente considerada; mas tivemos de ampliar o nosso horizonte para considerar o modo como uma determinada norma é tornada eficaz por uma organização complexa que determina a natureza e a importância das sanções, as pessoas que devem exercê-las e sua execução. Essa organização complexa é o produto de um ordenamento jurídico. Portanto, isso significa que uma definição satisfatória do direito só é possível se assumirmos o ponto de vista do ordenamento jurídico". BOBBIO, Norberto. Teoria geral do direito. São Paulo: Martins Fontes, 2008. p. 176.

${ }^{238}$ ZANCHIN, Kleber Luiz. Menos indenização na responsabilidade objetiva. In: HIRONAKA, Giselda Maria Fernandes Novaes; SIMÃO, José Fernando (Coords.). Ensaios sobre responsabilidade civil na pósmodernidade. Porto Alegre: Magister, 2009. v. 2, p. 226.

${ }^{239}$ BOBBIO, Norberto. A era dos direitos. Rio de Janeiro: Ed. Campus, 1992. p. 17.
} 
tais direitos, ou de justificar as razões pelas quais necessitem ser buscados por todos como algo querido. ${ }^{240}$

Decerto, nada é absoluto, nenhum fundamento e, consequentemente, nenhum direito possui o atributo do absolutismo, uma vez que os direitos variam no tempo e no espaço. A nossa história demonstra que direitos absolutos sucumbem com o tempo, a exemplo do direito de propriedade. ${ }^{241}$

Ainda nessa esteira, Bobbio demonstra outros motivos que vão ao encontro de sua tese que contesta a existência do fundamento absoluto, uma vez que os direitos do homem são variáveis, revelando contradições e antinomias. ${ }^{242}$

"O problema fundamental em relação aos direitos do homem, hoje, não é tanto o de 'justificá-los', mas o de protegê-los. Trata-se de problema não filosófico, mas político". ${ }^{243}$

É necessário asseverar que o direito à indenização por danos à esfera patrimonial ou extrapatrimonial da pessoa é direito fundamental, porquanto inserido no art. $5^{\circ}$ da $\mathrm{CF} / 88$ que, em seus incisos $\mathrm{V}$ e $\mathrm{X}$ aduzem, respectivamente que "é assegurado o direito de resposta, proporcional ao agravo, além de indenização por dano material, moral ou à imagem" e "são invioláveis a intimidade, a vida privada, a honra e a imagem das pessoas, assegurado o direito à indenização pelo dano material ou moral decorrente de sua violação".

A realidade social da vida moderna revela uma profunda necessidade de abertura, ainda maior, de modelos clássicos de proteção dos valores sociais mais relevantes, de forma a prevalecer sempre a tutela da pessoa. Dessa forma, não se pode permanecer inerte na interpretação dos institutos jurídicos. Se um direito é lesado o sistema deve conferir a resposta mais efetiva de modo a se resguardar a integralidade, tanto quanto possível, do bem jurídico protegido.

Os valores sociais mais importantes devem estar presentes no momento de se extrair o real significado da lei, vale dizer que o texto normativo pode permanecer o

\footnotetext{
${ }^{240}$ BOBBIO, Norberto. A era dos direitos, cit., p. 16-17.

${ }^{241}$ Id. Ibid., p. 18.

${ }^{242}$ Id. Ibid., p. 21

${ }^{243}$ Id. Ibid., p. 24.
} 
mesmo durante décadas, o que não implica que o resultado de sua análise será sempre o mesmo.

Insta ressaltar que, a lei não se confunde com o direito, sendo sempre o seu ponto de partida, mas nem sempre o seu ponto de chegada. ${ }^{244}$

A jurisprudência tem um papel relevante nessa construção axiológico-normativa, porquanto deve fazer a atualização necessária do texto normativo, compatibilizando-o com a ideologia dominante na sociedade.

O objetivo do direito é realizar a justiça. Não obstante, dependendo das circunstâncias históricas é possível que a realidade positiva perca espaço para a realidade jurídica. Demais disso, a justiça é, outrossim, um conceito histórico, dependendo das circunstâncias socioculturais e, inclusive, de aspectos subjetivos do intérprete ao analisar o direito posto. ${ }^{245}$

A evolução do direito, expressada nas decisões judiciais, é o resultado de pressões da sociedade e da utilização de consagrados elementos axiológicos. A jurisprudência possui força criativa no sentido de complementar a norma e se antecipar à própria lei formal, regulamentando situações sociais que exigem regramento adequado. Citem-se, assim, os casos atinentes ao reconhecimento de direitos da concubina, em que houve uma clara antecipação de nossos juízes, assim como os casos de dano moral. ${ }^{246}$

A função do intérprete é renovar com cautela e inteligência a ciência do direito, é o sociólogo do Direito. A sua atuação rejuvenesce o Direito, ultrapassando o vetusto texto legal, integrando e complementando a própria lei escrita. ${ }^{247}$

Com efeito, o dinamismo dos fatos sociais e da própria ideologia dominante em uma determinada sociedade pode não se refletir imediatamente no direito positivo, que não assimila com a rapidez almejada pelo grupo social, em razão do seu natural conservadorismo, as necessidades atuais da vida em comunidade.

Dessarte, nessas condições em que o direito positivo, em virtude do seu mencionado conservantismo, vai de encontro aos anseios sociais, é mister considerar a

\footnotetext{
${ }^{244}$ GOMES, Luiz Flávio. Aula. Programa Saber Direito. TV Justiça. Exibido em 30 jul. 2008.

${ }^{245}$ GRECO FILHO, Vicente. op. cit., p. 10.

${ }^{246}$ Id. Ibid.

${ }^{247}$ MAXIMILIANO, Carlos. Hermenêutica e aplicação do direito. 19. ed. Rio de Janeiro: Forense, 2003. p. 10.
} 
função da jurisprudência que deve aplicar o direito de acordo com a ideologia dominante, ou seja, de forma a fazer prevalecer os valores primários de uma sociedade, que é a própria razão de ser do sistema jurídico.

A interpretação de uma expressão jurídica não significa aclarar o respectivo dizer, abstratamente falando; é principalmente evidenciar o sentido adequado para a vida e em conformidade com uma decisão primada pela retidão. ${ }^{248}$

O texto normativo, expresso na lei, como é cediço, é de certa forma aberto, dando margem ao constante surgimento de normas, fenômeno que pode ser notado com maior constância pela legislação civilista atual, repleta de cláusulas gerais, o que propicia uma mais abrangente "oxigenação" e atualização do sistema jurídico sem que haja alterações na própria codificação.

A interpretação tem também a função de conceder o antes imprevisto, de acordo com uma análise do desdobramento natural da vida em sociedade, após a entrada em vigor de uma determinada lei.

É indubitável que os fatos da vida são muito mais criativos, abundantes e surpreendentes que a capacidade de antevê-los por qualquer ser humano. A adoção de cláusulas abertas e a hermenêutica podem, tranquilamente, dar o significado adequado ao texto normativo de acordo com as exigências da sociedade contemporânea.

Essa maneira, mais aberta, de se elaborar o texto normativo constituiu uma das grandes novidades trazidas pelo novo Código Civil, que incorporou uma principiologia diferente daquela que vigorou com o Código Civil de 1916.

De fato, três são os princípios estruturais da mais recente codificação civilista, que modificou a forma de interpretar essa legislação, exigindo mais cuidado e criatividade por parte do intérprete, mormente em virtude das cláusulas gerais.

Assim, fala-se me princípio da socialidade, eticidade e operabilidade ou concretude. $^{249}$

O princípio da socialidade preconiza que o intérprete, no momento de extrair a norma do texto normativo, deve fazer prevalecer os valores coletivos em detrimento dos

\footnotetext{
${ }^{248}$ MAXIMILIANO, Carlos. op. cit., p. 8.

${ }^{249}$ REALE, Miguel. Visão geral do novo Código Civil. In: ampl. São Paulo: Ed. Revista dos Tribunais, 2003. p. 12-17. . Novo Código Civil brasileiro. 3. ed. rev. e
} 
individuais. É a superação do caráter individualista que prevalecia na codificação anterior. $^{250}$

No entanto, é imperioso reconhecer que não pode o hermeneuta prescindir, em razão de expressivo comando constitucional, do mega-princípio da dignidade da pessoa humana no momento de interpretar os institutos jurídicos.

Nas palavras de Miguel Reale:

"Hoje em dia, vive o povo brasileiro nas cidades, na mesma proporção de $80 \%$, o que representa uma alteração de 180 graus na mentalidade reinante, inclusive em razão dos meios de comunicação, como o rádio e a televisão. Daí o predomínio do social sobre o individual". ${ }^{251}$

Como é consabido, nos idos de 1900, época de tramitação do Código Civil de 1916, a sociedade brasileira tinha características bem distintas daquelas apresentadas hoje, sendo que a primordial distinção encontrava-se no fato de que naquela época a sociedade pátria era eminentemente rural. ${ }^{252} \mathrm{~A}$ análise desse momento histórico é extremamente relevante, para que possamos entender o escopo principal da codificação que estava por vir e seus reflexos na sociedade do século XX.

Assim, a legislação civilista pretérita, que veio em um momento de sistematização da ordem jurídica brasileira, tencionava regrar a vida das pessoas que viviam na zona rural. A sua finalidade era atender aos interesses do cidadão que morava nas fazendas e que reunia em si o papel do comerciante, proprietário, pai, marido e testador. ${ }^{253}$

A família, daquela época, possuía uma estrutura bastante diferente. Havia uma hierarquia, corolário do pensamento machista que predominava no seio social e que, em razão disso, atribuía ao marido a condição de chefe de uma família fechada, que poderia constituir-se apenas pelo casamento. ${ }^{254}$

Deveras, o matrimônio, naquele momento histórico, era o único instituto capaz de criar a família tutelada pelo Estado. O afeto não tinha a relevância de hoje para a formação

\footnotetext{
${ }^{250}$ REALE, Miguel. Visão geral do novo Código Civil, cit., p. 13.

${ }^{251}$ Id. Ibid., p. 14.

${ }^{252}$ Id. Ibid., p. 13.

${ }^{253}$ MEIRELLES, Jussara. O ser e o ter na codificação civil brasileira: do sujeito virtual à clausura patrimonial. In: FACHIN, Luiz Edson (Coord.). Repensando fundamentos do direito civil brasileiro contemporâneo. 2. tir. Rio de Janeiro: Renovar, 2000. p. 95.

${ }^{254}$ DIAS, Maria Berenice. op. cit., p. 43.
} 
de outras entidades familiares, porquanto, não rara vez, o casamento era combinado entre as famílias, com o fim de permitir a proteção do patrimônio amealhado pelas gerações passadas, ou seja, havia um predomínio do patrimônio em detrimento da pessoa. ${ }^{255}$

Destarte, a família tinha uma estrutura bem fechada que impossibilitava a sua dissolução, justamente para se tutelar o patrimônio que, como explicitado, tinha um peso importante na formação da família, máxime na escolha dos futuros cônjuges. ${ }^{256}$

Dessa forma, não havia, na época, o divórcio e tampouco a possibilidade de reconhecimento de filhos fora do casamento, tudo em conformidade com os valores predominantes, naquele momento histórico, mormente o de preservação do patrimônio que não poderia se afastar do núcleo familiar.

No que concerne ao contrato, vigorava um pensamento tecnicista e clássico quanto à estrutura deste negócio jurídico bilateral, em que não havia a imposição de uma limitação razoável da autonomia da vontade entre os contratantes, tornando esse instituto, por vezes, uma forma de opressão dos mais fortes sobre os mais fracos.

Com o transcorrer das décadas, a sociedade foi conscientizando-se de que o modelo acima explanado não servia mais para atender às necessidades.

A propriedade, influenciada pelo Código Napoleão, surge com as suas faculdades também pouco limitadas pelo ordenamento jurídico pátrio. Fato esse que se traduzia em uma propriedade quase que absoluta.

Assim, é mister considerar que os principais institutos do direito civil, tais como: o contrato, a propriedade, a família e a responsabilidade civil receberam influxos diretos

\footnotetext{
${ }^{255}$ DIAS, Maria Berenice. op. cit., p. 30.

${ }^{256}$ Maria Berenice Dias, ao tratar das características da família, que o Código Civil de 1916 buscava tutelar, assevera que: "O Estado solenizou o casamento como uma instituição e o regulamentou exaustivamente. Os vínculos interpessoais passaram a necessitar da chancela estatal. É o Estado que celebra o matrimônio mediante o atendimento de inúmeras formalidades. Reproduziu o legislador civil de 1916 o perfil da família então existente: matrimonializada, patriarcal, hierarquizada, patrimonializada e heterossexual. Só era reconhecida a família constituída pelo casamento. O homem exercia a chefia da sociedade conjugal, sendo merecedor de respeito e obediência da mulher e dos filhos. A finalidade essencial da família era a conservação do patrimônio, precisando gerar filhos como força de trabalho. Como era fundamental a capacidade procriativa, claro que as famílias necessitavam ser constituídas por um par heterossexual e fértil”. DIAS, Maria Berenice. op. cit., p. 43.
} 
dessa mudança ideológica-jurídica advinda da previsão implícita, pelo novo sistema privado, do princípio da socialidade. ${ }^{257}$

Outro princípio basilar, da nova codificação, é o princípio da eticidade que proporcionou uma aproximação do Direito com a ética, proximidade que modificou a forma de se pensar e interpretar institutos jurídicos tradicionais. ${ }^{258}$

Esse princípio traz a necessidade de se conferir ao texto normativo uma interpretação em conformidade com valores dominantes, sobressaindo os critérios éticojurídicos, em detrimento dos critérios lógico-formais. ${ }^{259}$

Por fim, tem-se o denominado princípio da operabilidade ou da concretude que espelha o pensamento do legislador em elaborar um conjunto normativo para o homem concreto, deixando-se para trás celeumas doutrinárias que prejudicariam a compreensão, do novo código, pelo destinatário imediato do novel sistema.

Outro desdobramento do princípio da operabilidade é ser possível a atualização do sistema, automaticamente, em razão da previsão, por inúmeros dispositivos, de cláusulas gerais que permitem a análise do caso concreto com maior liberdade por parte do julgador. $^{260}$

Assim sendo, esse cenário de mudanças estruturais significativas influenciou a maneira de se pensar todos os institutos do Código Reale, potencializando uma profunda abertura interpretativa, o que possibilitará a extração da norma jurídica de uma maneira mais harmônica com a principiologia da atual codificação civil.

Deve-se considerar, além disso, que é impossível que as normas, ainda que bem elaboradas, consigam espelhar a realidade em todas as suas faces: neque leges, neque

\footnotetext{
${ }^{257}$ Há uma série de artigos que podem ser citados que expressam, com precisão, a interferência direta do princípio da socialidade da nova codificação civil. São eles: arts. $421,423,1.228, \S \S 4^{\circ}$ e $5^{\circ}, 1.238,1.239$, 1.242 e 187.

${ }^{258}$ REALE, Miguel. Visão geral do novo Código Civil, cit., p. 13.

${ }^{259}$ Francisco Amaral assevera que: "O princípio da Eticidade sobreleva critérios ético-jurídicos em relação aos critérios lógico-formais, no processo de concreção jurídica. O Juiz é chamado a criar a norma para o caso concreto, pela mediação de princípios e regras do sistema, de conformidade com valores dominantes. Representa esse princípio, também, a crença de que o equilíbrio econômico dos contratos é a base ética de todo o direito obrigacional, o que o aproxima do Princípio da Boa-Fé, no seu sentido ético, objetivo. Positiva-se esse princípio nos artigos 113, 187 e 422 do Código Civil." In AMARAL, Francisco. op. cit., p. 93.

${ }^{260}$ REALE, Miguel. Visão geral do novo Código Civil, cit., p. 16.
} 
senatusconsulta ita scribi possunt, ut omnes casus qui quandoque inciderint comprehendatur. ${ }^{261}$

Por mais capacitados que sejam os legisladores, pouco tempo depois de promulgada uma lei, começam a surgir dúvidas acerca de aspectos de sua aplicabilidade, ainda que se trate de dispositivos bem redigidos. Nenhuma pessoa, por mais hábil que seja, seria capaz de prever em toda a sua plenitude a imensa gama de conflitos de interesses entre as pessoas. O texto expresso e as realidades objetivas nem sempre se encontram em sintonia. A fixação do Direito Positivo não implica a estagnação da criatividade da vida que continua se desenvolvendo em seus múltiplos aspectos. ${ }^{262}$

Muitas vezes, o intérprete deve vislumbrar a essência do texto normativo para retirar a norma jurídica aplicável ao caso concreto. O texto da lei não tem o condão de descrever precisamente todas as circunstâncias que devem ser por ele abarcadas, necessitando, por conseguinte, da análise do aplicador da norma para uma justa e abrangente subsunção.

Com efeito, é dever do jurista enxergar a norma em todas as suas ramificações, ainda que estejam no âmago do texto escrito. A extensão da aplicação do texto normativo não pode cingir-se aos aspectos fáticos, expressamente descritos e vislumbrados pelo aplicador da norma, por intermédio de uma interpretação estritamente gramatical.

“O jurista, esclarecido pela Hermenêutica, descobre, em Código, ou em um ato escrito, a frase implícita, mais diretamente aplicável a um fato do que o texto expresso. Multiplica as utilidades de uma obra; afirma o que o legislador decretaria, se previsse o incidente e o quisesse prevenir ou resolver, intervém como auxiliar prestimoso da realização do Direito. Granjeia especiais determinações, não por meio de novos dispositivos materializados, e, sim, pela concretização e desdobramento prático dos preceitos formais. Não perturba a harmonia do conjunto, nem altera as linhas arquitetônicas da obra; desce aos alicerces, e dali arranca tesouros de idéias, latentes até aquele dia, porém vivazes e lúcidos. Explica a matéria, afasta as contradições aparentes, dissipa as obscuridades e faltas de precisão, põe em relevo todo o conteúdo do preceito

\footnotetext{
${ }^{261}$ MAXIMILIANO, Carlos. op. cit., p. 10.

${ }^{262}$ Id. Ibid.
} 
legal, deduz das disposições isoladas o princípio que lhes forma a base, e desse princípio as conseqüências que do mesmo decorrem". ${ }^{263}$

São admitidas na interpretação o emprego de componentes sociológicos, axiológicos, teleológicos etc., como sempre ressaltado pela Lei de Introdução ao Código Civil. Não se almeja o apego a um positivismo legalista, literal e comodista. ${ }^{264}$

As expressões trazidas pelo texto escrito da lei, e que devem ser sempre interpretadas, necessitam traduzir sintonia com os princípios do instituto que regulam.

No caso da responsabilidade civil, objeto de nossa análise, o seu escopo precípuo é fornecer os meios necessários para reconstruir uma realidade jurídica e, principalmente, fática que forem comprometidas por ato de outrem.

É natural que a aplicação do instituto, acima referido, não pode suprimir direitos fundamentais de uns para reparar os danos suportados por outros. O que se pretende defender é a possibilidade de ampliar a interpretação de textos, aparentemente taxativos, para abarcar situações que possuam a mesma essência das circunstâncias explicitamente disciplinadas por eles.

Sobreleva ressaltar que, as palavras em um texto normativo não possuem a rigidez que aparentam. Têm os atributos da elasticidade e da ductilidade, mudam de significação com o passar dos tempos e com o desenvolvimento da civilização. Ostentam, dessa forma, a vantagem de demonstrar as sucessivas realidades jurídicas. ${ }^{265}$

Se não há direitos absolutos, a lógica do sistema traz a ilação de que tampouco há garantias cabais de intangibilidade daquilo que parece ser impenetrável.

Assim, se, em um primeiro momento, tem-se a impressão de que a responsabilidade por fato de terceiro, como será visto no capítulo seguinte, expressa um sistema extremamente fechado, em que prepondera o vetor segurança jurídica e a garantia absoluta de que não há extensão da obrigatoriedade em reparar os danos de outrem, além daqueles casos previstos na lei, a modernidade da ciência jurídica aliada à jurisprudência alhures colacionada, aponta a necessidade de reanálise dessa postura clássica, com o objetivo de

\footnotetext{
${ }^{263}$ MAXIMILIANO, Carlos. op. cit., p. 12.

${ }^{264}$ GRECO FILHO, Vicente. op. cit., p. 18.

${ }^{265}$ MAXIMILIANO, Carlos. op. cit., p. 13.
} 
conferir respostas semelhantes a circunstâncias fáticas similares. "Faz-se necessária...a flexibilização da interpretação das normas de responsabilidade civil". ${ }^{266}$

De fato, é imperioso reconhecer que nenhuma novidade está sendo aqui referida, porquanto há súmula do STF que amplia a interpretação do dispositivo do Código Civil (art. 932) que trata da matéria aqui debatida e que será detalhada no capítulo pertinente. Ou seja, já se reconheceu uma ampliação do rol de legitimados a responderem por danos causados por terceiros, mitigando, inclusive, os rigores da regra de que a solidariedade não se presume, resulta da lei ou da vontade das partes.

Trata-se da súmula $\mathrm{n}^{\circ}$ 492, do STF, com os seguintes dizeres: “A empresa locadora de veículos responde, civil e solidariamente com o locatário, pelos danos por este causados a terceiros, no uso do carro locado".

O envelhecimento dos códigos minimiza, se não elide, o legalismo predominante durante o século XIX. Vislumbra-se cada vez mais a importância que a doutrina e a jurisprudência possuem, no desenvolvimento do direito, e nenhum jurista hodiernamente acredita que apenas os textos legislativos são importantes para a interpretação do direito. $\mathrm{O}$ ressurgimento da idéia de direito natural, que se verifica nesta época, faz renascer o pensamento de direito comum. Assim, elimina-se a idéia de que o direito é somente a lei. $^{267}$

Além disso, ainda que não se trate de súmula vinculante, é irrefutável sua força na aplicação e interpretação do direito, haja vista o fato de serem as súmulas fontes indiretas ou mediatas do direito.

Essa afirmação corrobora-se ainda mais, hoje, após as sucessivas reformas processuais que visaram e visam a implementar ao processo civil maior celeridade e efetividade na prestação jurisdicional, conformando esse ramo do direito aos ditames e princípios constitucionais.

Com efeito, inúmeros são os artigos previstos no diploma processual civil que enaltecem as súmulas e a jurisprudência, ainda que não vinculantes, demonstrando a sua importância cada vez maior na aplicação do direito. De acordo com esse sentido, a sistemática processual civil, assim como a própria Constituição Federal, após a Emenda no

\footnotetext{
${ }^{266}$ LOPEZ, Teresa Ancona. Princípio da precaução e evolução da responsabilidade civil, cit., p. 158.

${ }^{267}$ DAVID, René. Lês grand systéme de droit contemporains. 7. ed. Paris: Dalloz, 1978. p. 66.
} 
45, com o escopo de permitirem uma justiça mais célere e, por conseguinte, mais eficiente, trouxeram uma série de dispositivos que passaram a incorporar, consequentemente, o ordenamento pátrio e, não seria exagero afirmar, aproximaram o direito brasileiro da Common Law. ${ }^{268}$ Trata-se dos artigos 120, parágrafo único, 285-A, ${ }^{269} 518, \S 1^{\circ}, 557$, caput, todos do Código de Processo Civil.

Neste diapasão, Diego Corapi aduz que, apesar do direito brasileiro pertencer à tradição do direito romano-germânico, caracteriza-se, também, por um "ecletismo nas elaborações doutrinárias, nas fontes normativas." Sentencia, referido autor, que é notável a diferença existente em nosso ordenamento entre o direito estudado nas universidades e aquele posto em prática pelos tribunais. De acordo com sua análise, assevera, também, que a jurisprudência brasileira desenvolve, hoje, um papel mais preponderante e que, após a entrada em vigor da emenda $n^{\circ}$. 45 , assumiu o sistema jurídico nacional uma posição mais próxima e consentânea com a common law. ${ }^{270}$

Realmente, mencionando novamente a súmula 492 do STF e suas possíveis consequências no que se refere à sua eficácia perante o sistema, é imperioso reconhecer que a idéia de que a solidariedade não se presume, resulta da lei ou da vontade das partes, pode ser considerada mitigada em virtude do poder conferido pelo ordenamento jurídico às

\footnotetext{
${ }^{268}$ De acordo com Luiz Roldão de Freitas Gomes: "Pode-se hoje dizer, sem receio, máxime após a vigência da atual carta Magna, consagrando os princípios da responsabilidade civil em dano moral, da ofensa a bens imateriais, como o meio ambiente, o patrimônio histórico, artístico e paisagístico, que as diretrizes da responsabilidade civil se traçam mais na reiteração dos julgados do que propriamente em preceitos do Código. O arbitramento da indenização, a prova do dano e outros elementos fundamentais para determinála levam o julgador à feição do Magistrado na Common Law, a concretizar rumos na matéria." GOMES, Luiz Roldão de Freitas. Elementos de responsabilidade civil. Rio de Janeiro: Renovar, 2000. p. 21.

Neste sentido, Guido Fernando Silva Soares leciona que: "Na Common Law, a idéia que permeia o sistema é de que o direito não existe para ser um edifício lógico e sistemático, mas para resolver questões concretas". SOARES, Guido Fernando da Silva. op. cit., p. 53. Vale a pena frisar que, um pouco antes, o mencionado Professor aseverou que: "Na Common Law, um único julgado é considerado como precedente obrigatório, pois declara a existência de uma norma jurídica, para o 'fattispecie', sendo, portanto, a jurisprudência a fonte primeira do direito.” Id. Ibid., p. 52.

${ }^{269}$ Humberto Theodoro Junior ensina que: "O art. 285-A, introduzido no Código pela Lei no 11.2777 , emprega a mesma técnica de economia processual às causas seriadas ou repetitivas, tão comuns em relação aos direitos do funcionalismo público e às obrigações tributárias ou previdenciárias. Um mesmo tema, sobre uma só questão de direito, repete-se cansativamente, por centenas e até milhares de vezes". THEODORO JÚNIOR, Humberto. Curso de direito processual civil: teoria geral do direito processual civil e processo de conhecimento. 50. ed. Rio de Janeiro: Forense, 2009. v. 1, p. 351.

${ }^{270}$ Afirma Diego Corapi que: "In definitiva, il diritto brasiliano ha recepito com grande eclettismo la tradizione romanistica, ponendo comunque la codificazione al centro del sistema di diritto privato, ha ricevuto altresì influssi del diritto costituzionali degli Stati Uniti e di istituti, sopratuto commerciali dela common law ed è connotato da um forte distacco, un dualismo, tra la law in the books e la law in action". CORAPI, Diego. Tradizione romanistica e influeze di common law nell'evoluzione del diritto brasiliano. $R T D C$ : revista trimestral de direito civil, Rio de Janeiro, ano 9, v. 34, p. 107-112, abr.jun. 2008.
} 
súmulas e às decisões de nossos tribunais, após o início da implementação da reforma processual, a partir de $1994 .^{271}$

Dessa forma, realizando-se uma interpretação sistemática do instituto da solidariedade, é possível fazer uma nova leitura desse importante fenômeno do direito material e asseverar, conseqüentemente, que a solidariedade não se presume; resulta da lei, da vontade das partes ou de súmula de Tribunal Superior, o que demonstra que a necessidade de uma justiça mais célere e eficiente, em razão da complexidade da vida social, se sobrepõe até mesmo a questões dogmáticas do direito material. É mister explicitar que a celeridade e a duração razoável do processo ganharam contornos de direito fundamental com a Emenda n ${ }^{\circ} 45 .^{272}$

Destarte, é necessário reconhecer, após esta singela análise desses dispositivos processuais, que já houve uma abertura do sistema para permitir que outros casos de responsabilidade civil indireta possam ser avocados com o intuito de preservar os interesses da pessoa ofendida em sua esfera jurídica de direitos.

Assim, resta claro que o sistema, apesar de ser aparentemente fechado, possui uma abertura significativa de modo a possibilitar a busca da justiça, no caso concreto, afastando, por vezes, leituras prontas e acabadas de dispositivos que impossibilitam o hermeneuta de buscar soluções mais consentâneas com o dinamismo social.

A respeito da necessidade da abertura maior do sistema para o alcance da justiça, no momento de interpretação das normas jurídicas, são preciosas as lições de Giselda Hironaka para quem as verdades absolutas são perigosas, uma vez que impedem revisões futuras. Assevera que a busca pelo seguro intimida as remodelações. Dessa forma, o receio, no que tange às consequências de pensamentos jurídicos novos e inovadores, acaba atrapalhando a busca de uma justiça justa. ${ }^{273}$

\footnotetext{
${ }^{271}$ De acordo com o artigo 265, do Código Civil, "A solidariedade não se presume; resulta da lei ou da vontade das partes".

${ }^{272}$ Art. $5^{\circ}$, LXXVIII, da CF/88, dispõe que: "a todos, no âmbito judicial e administrativo, são assegurados a razoável duração do processo e os meios que garantam a celeridade de sua tramitação".

${ }^{273}$ HIRONAKA, Giselda Maria Fernandes Novaes. Sobre peixes e afeto: um devaneio sobre a ética no direito de família. In: PEREIRA, Rodrigo da Cunha (Coord.). Família e dignidade humana. In: CONGRESSO BRASILEIRO DE DIREITO DE FAMÍLIA, 5. Anais... Belo Horizonte: IBDFAM, 2006. p. 426.
} 
Destarte, se há autoridade dos pais em relações aos filhos, ${ }^{274}$ ainda que capazes, por serem economicamente dependentes, é forçoso convir que essa circunstância fática se assemelha, em muito, com a situação em que os genitores detêm as prerrogativas e sujeições inerentes ao poder familiar. Como visto, poder-se-ia falar, inclusive, em prolongamento do próprio poder familiar.

Assim, se durante a incapacidade da pessoa, os seus genitores são obrigados, por expressa disposição legal, a indenizar os danos causados por seus filhos menores a terceiros, caso o filho capaz continue a se submeter à autoridade de fato dos seus progenitores, a resposta jurídica também deve ser semelhante, possibilitando a responsabilidade subsidiária dos pais, na hipótese em que o filho capaz não possua patrimônio idôneo para indenizar eventuais prejuízos que causem a outrem.

\footnotetext{
${ }^{274}$ Caio Mário da Silva Pereira, citando De Page, assevera que: "Em qualquer dos casos previstos na lei, milita uma idéia que é comum a todos: o terceiro é responsável quando dispõe de uma autoridade de direito ou de fato sobre os outros". PEREIRA, Caio Mário da Silva. Responsabilidade civil (de Acordo com a Constituição de 1988). 9. ed. Rio de Janeiro: Forense, 1999. p. 85-86.
} 


\section{A RESPONSABILIDADE CIVIL}

\subsection{Breves considerações históricas a respeito da responsabilidade civil dos pais}

Um dos mais expressivos capítulos da ciência jurídica, isto é, a responsabilidade civil, tem origem etimológica no termo latino, respondere, e significa a obrigação que emerge de se responsabilizar alguém por seus atos lesivos.

$\mathrm{Na}$ fase mais primitiva da cultura humana, a reparação do ato lesivo resumia-se na retribuição do mal pelo mal, verdadeira vingança privada, como expressava a pena de talião, ou seja: olho por olho, dente por dente. Contudo, na vingança privada não havia qualquer vestígio de reparação, mas, na realidade, dupla lesão, a da vítima e a de seu ofensor, depois de punido.

A responsabilidade civil, que tem como pressuposto um equilíbrio a ser restabelecido pela reparação, pode ser entendida como a obrigação ${ }^{275}$ de indenizar os danos produzidos na esfera de direitos de outrem, seja por ato próprio, por ato de terceiro ou de coisa a si dependentes.

Classicamente, de acordo com as lições doutrinárias, pode-se dizer que as funções da responsabilidade civil são compensatórias ou reparatórias, quando dizem respeito a dano moral ou patrimonial respectivamente. O dano moral, diferentemente do dano material, não pode ser reparado, devendo, por conseguinte, ser compensado. ${ }^{276}$

Nas palavras de Serpa Lopes, ao conceituar responsabilidade civil, temos que:

\footnotetext{
${ }^{275}$ Para José Carlos Moreira Alves: “A expressão fonte da obrigação pode ser empregada, como acentua Stolfi, em dois sentidos: a) como norma jurídica que dá eficácia ao vinculum iuris, requisito da obrigação; e b) como fato jurídico de que resulta o nascimento da obrigação. No primeiro sentido, fonte da obrigação é unicamente a norma jurídica (lei em sentido amplo); no segundo, qualquer fato que, sancionado pela ordem jurídica, dê nascimento a uma relação obrigacional. Em outras palavras, todas as obrigações decorrem mediatamente de uma norma jurídica (lei em sentido amplo), e, imediatamente, de um fato jurídico (isto é, de um fato voluntário, ou não, a que a norma jurídica atribui o poder de fazer surgir uma obrigação)". ALVES, José Carlos Moreira. Direito romano. 14. ed. Rio de Janeiro, 2007. p. 397.

${ }^{276}$ CHINELATO, Silmara Juny de Abreu. Tendências da responsabilidade civil no direito contemporâneo: reflexos no Código de 2002. In: DELGADO, Luiz Mario; ALVES Jones Figueiredo (Coords.). Questões controvertidas no novo Código Civil (Responsabilidade Civil). São Paulo, 2006. v. 5, p. 586. Não obstante, de acordo com as lições de Teresa Ancona Lopes, a responsabilidade civil contemporânea possui outras funções: função reparatória, dissuasória e preventiva. LOPEZ, Teresa Ancona. Princípio da precaução e evolução da responsabilidade civil, cit., p. 154.
} 
“A violação de um direito gera a responsabilidade em relação ao que a perpetrou. Todo ato executado ou omitido em desobediência a uma norma jurídica, contendo um preceito de proibição ou de ordem, representa uma injúria pública, conforme a natureza dos interesses afetados, se individuais ou coletivos". 277

Silvio Rodrigues, em seu curso de Direito Civil, define o instituto da responsabilidade civil como a obrigação que incumbe a uma pessoa de reparar o prejuízo causado a outra, por fato próprio, ou por fato de pessoas ou coisas que dela dependam. ${ }^{278}$

Dessa forma, resta evidente que a responsabilidade civil ${ }^{279}$ emerge diretamente de um ato lesivo, e tem a marca de fonte das obrigações, assim como o contrato, os atos unilaterais e as declarações unilaterais de vontade, tendo, todas essas fontes, fundamento maior na lei em decorrência do princípio da legalidade inserido no art. $5^{\circ}$, II, da Constituição Federal de $1988 .^{280}$ Diz-se ser o mencionado instituto fonte de obrigação, haja

${ }^{277}$ LOPES, Miguel de Serpa. Curso de direito civil. 8. ed. rev. atual. Rio de Janeiro: Freitas Bastos, 1996. v. 8 , p. 550-551.

${ }^{278}$ RODRIGUES, Silvio. Direito civil: responsabilidade civil. 17. ed. São Paulo. Saraiva, 1999. v. 4, p. 6.

${ }^{279}$ Para Sílvio de Salvo Venosa, "o termo responsabilidade civil é utilizado em qualquer situação na qual alguma pessoa, natural ou jurídica, deva arcar com as consequiências de um ato, fato ou negócio danoso. Sob essa noção, toda atividade humana, portanto, pode acarretar o dever de indenizar. Desse modo, o estudo da responsabilidade civil abrange todo o conjunto de princípios e normas que regem a obrigação de indenizar. Os princípios da responsabilidade civil buscam restaurar um equilíbrio patrimonial e moral violado. Um prejuízo ou dano não reparado é um fator de inquietação social. Os ordenamentos contemporâneos buscam alargar cada vez mais o dever de indenizar, alcançando novos horizontes, a fim de que cada vez menos restem danos irressarcidos." (grifos nossos). VENOSA, Silvio de Salvo. Direito civil: responsabilidade civil. 8. ed. São Paulo: Atlas, 2008. v. 4, p. 1-2.

Já para Maria Helena Diniz, "grandes são as dificuldades que a doutrina tem confrontado para conceituar a responsabilidade civil. Autores existem que se baseiam, ao defini-la, na culpa. P. ex.: Pirson e Villé conceituam a responsabilidade como obrigação imposta pelas normas às pessoas no sentido de responder pelas consequiências prejudiciais de suas ações; Sourdat a define como o dever de reparar dano decorrente de fato de que se é autor direto ou indireto, e Savatier a considera como a obrigação de alguém reparar dano causado a outrem por fato seu, ou pelo fato das pessoas ou coisas que dela dependam." (grifos nossos). DINIZ, Maria Helena. Curso de direito civil brasileiro: responsabilidade civil. 17. ed. São Paulo: Saraiva, 2003. v. 7, p. 35-36.

Outro autor que conceitua a responsabilidade civil, com a abrangência que se quer utilizar para fundamentar a presente dissertação é José Fernando Simão, que a define com os seguintes dizeres: "Responsabilidade civil é a obrigação de indenizar os danos materiais e morais causados a outrem por fato próprio, ou por fato de pessoas ou de coisas que dela dependam”. (grifos nossos). SIMÃO, José Fernando. Responsabilidade civil pelo fato do animal: estudo comparativo dos Códigos Civis de 1916 e de 2002. In: DELGADO, Luiz Mario; ALVES Jones Figueiredo (Coords.). Questões controvertidas no novo Código Civil (Responsabilidade civil). São Paulo, 2006. v. 5, p. 344. O jovem adulto, maior de 18 anos, que vive sob a dependência econômica de seus pais depende deles para manter a sua subsistência, encontrandose, conseguintemente, na mesma situação fática que um filho menor de 18 anos.

${ }^{280} \mathrm{Ar}$. $5^{\circ}$ "Todos são iguais perante a lei, sem distinção de qualquer natureza, garantindo-se aos brasileiros e aos estrangeiros residentes no País a inviolabilidade do direito à vida, à liberdade, à igualdade, à segurança e à propriedade, nos termos seguintes". "II- ninguém será obrigado a fazer ou deixar de fazer alguma coisa senão em virtude de lei." 
vista o surgimento do dever de indenizar àquele que realiza conduta produtora de dano ao patrimônio jurídico de outrem.

É mister esclarecer que essa responsabilidade pode ser contratual ou extracontratual, dependendo da espécie de descumprimento obrigacional, sendo interessante explicitar que o sistema jurídico pátrio diferenciou as duas espécies de responsabilidade, perfilhando a teoria dualista e elidindo, dessa forma, a teoria unitária. ${ }^{281}$ O devedor pode deixar de adimplir uma obrigação advinda de um contrato ou inobservar o sistema normativo que rege a sua vida. Na primeira hipótese, fala-se em responsabilidade contratual e, na segunda, em responsabilidade extracontratual. ${ }^{282}$

A doutrina também denomina a responsabilidade extracontratual de responsabilidade aquiliana, uma vez que a Lex Aquilia de damno (do século III a.c) disciplinou os fundamentos jurídicos dessa forma de responsabilidade civil, no direito romano, estabelecendo uma maneira pecuniária de indenização do dano ${ }^{283}$, assentada na estipulação de seu montante. Antes, vigorava a pena de Talião ("olho por olho, dente por dente), com fundamento na vingança privada em que se fazia justiça com as próprias mãos. $^{284}$

Para se ter uma visão completa da evolução da responsabilidade civil, é conveniente asseverar que, no Direito Romano, referido instituto teve sua origem na vingança privada. Posteriormente, o poder público passa a intervir de forma a permiti-la ou excluí-la quando sem justificativa. Trata-se da Lei de Talião que encontra marcas na lei das XII Tábuas. ${ }^{285}$

\footnotetext{
${ }^{281}$ GONÇALVES, Carlos Roberto. Direito civil brasileiro: parte geral, cit., v. 1, p. 164.

${ }^{282}$ AZEVEDO, Álvaro Villaça. Teoria geral das obrigações. 3. ed. São Paulo: Ed. Revista dos Tribunais, 1981. p. 294.

${ }^{283}$ De acordo com o escólio de Cristián Aedo Barrena: "Como se sabe, la lex aquilia correspondió a un plebiscito rogado por el tribuno Aquilio, cuya datación es imprecisa, aunque parece remontarse ao siglo III a.C. Constaba de tres capítulos". AEDO BARRENA, Cristián. Los requisitos de la lex Aquilia, con especial referencia al daño: lecturas desde las distintas teorías sobre el capítulo tercero. Ius et Praxis, Universidad de Talca, año 15, n. 1, p. 312, 2009. Alexandre Correia e Gaetano Sciascia lecionam que: "A lex Aqulia de damno, plebiscito posterior à lei Hortênsia, do III século antes de cristo, no seu primeiro capítulo estabeleceu, que quem tivesse morto um escravo ou um animal alheio, fosse condenado no mais alto valor que tivesse tido no ano anterior ao delito. No terceiro capítulo dispunha, que quem tivesse ferido um escravo ou um animal alheio, como também destruído ou deteriorado coisa corpórea alheia, devesse pagar ao proprietário o mais alto valor que o objeto tivera nos trinta dias precedentes ao delito". CORREIA, Alexandre; SCIASCIA, Gaetano. Manual de direito romano. 4. ed. São Paulo:Saraiva, 1961. v. 1, p. 366.

${ }^{284}$ AZEVEDO, Álvaro Villaça. Responsabilidade civil-I. In: FRANÇA, Rubens Limongi (Org.). Enciclopédia Saraiva do Direito. São Paulo: Saraiva, 1977. v. 65, p. 333.

${ }^{285}$ LIMA, Alvino. Da culpa ao risco. São Paulo: Empresa Gráfica da Revista dos Tribunais, 1938. p. 11-12.
} 
No antigo direito romano, prevalecia a noção básica de delito e, por isso, praticado o mesmo, surgia para a vítima o direito correspondente à vingança (privada) proporcional ao delito, sem qualquer preocupação com a questão da imputabilidade. $\mathrm{Na}$ origem do instituto, "a idéia predominante é a vingança privada". ${ }^{286}$

Ainda, nesse caso, como supracitado, após a Lei de Talião ${ }^{287}$ temos como lei fundamental em Roma a Lex Aquilia de Damno (do século III a.c), que criou o chamado damno iniuria datum, ou seja, o dano causado contra a lei e estabeleceu, no Direito Romano, as bases jurídicas da responsabilidade civil extracontratual. ${ }^{288}$ Essa lei foi estabelecida em favor da plebe ${ }^{289}$, ou seja, para proteger os plebeus contra os danos que lhes eram ocasionados pelos patrícios. ${ }^{290}$ É necessário explicitar que, por meio da Lei Aquília, ensinava Ulpiano, a mais leve culpa deve ser considerada (in lege Aquilia et levíssima culpa venit). ${ }^{291}$

José Cretella Junior, ao discorrer a respeito do damnum iniuria datum, leciona que: "Antes da Lei Aquília, imperava o regime jurídico da Lei das XII Tábuas, que continha regras isoladas, ao contrário do estado aquiliano, que é uma verdadeira sistematização no sentido de punir através de um determinado tipo de ação todos os atos prejudiciais a alguém. No período pré-aquiliano, a actio de arboribus succisis punia a pessoa que cortasse as árvores do vizinho, a actio incensarum punia quem incendiasse algo, involuntariamente, a actio de pastu era movida contra quem fizesse pastar seu rebanho em pastagens alheias. No regime da Lei Aquília, é introduzido um novo delito civil - o damnum iniuria

\footnotetext{
${ }^{286}$ PEREIRA, Caio Mário da Silva. Responsabilidade civil (de Acordo com a Constituição de 1988), cit., p. 6.

287"Primitivamente, aplicava-se a pena do Talião ("olho por olho, dente por dente"), baseada na vingança privada em que os homens faziam justiça pelas próprias mãos. Resquícios dessa pena do talião encontramse na Lei das XII Tábuas. A Tábua VII, Lei $11^{\mathrm{a}}$ - De delictis - consagra-a, com o seguinte texto: $11-s i$ membrum rupstit, ni cum eo pacit, talio esto - (Se alguém fere a outrem, que sofra a pena do Talião, salvo se existiu acordo)". AZEVEDO, Álvaro Villaça. Proposta de classificação da responsabilidade objetiva: pura e impura. Revista dos Tribunais, Sao Paulo, v. 82, n. 698, p. 8, dez. 1993.

${ }^{288}$ Id., loc. cit.

${ }^{289}$ Diz Silvio A. B. Meira que “....as lutas entre patriciado e plebe, que se desenvolviam desde a fundação da cidade, não se limitavam à questão de terras. A sociedade romana, em suas origens no $8^{\circ}$ século antes de cristo, já se dividia em duas grandes categorias (para não usar da palavra classes): patrícios e plebeus... A verdade é que segundo a tradição, os patrícios inicialmente eram os senhores absolutos dos altos postos públicos, integravam sozinhos os Comitia Curiata, o Senado, guardavam zelosos o seu Jus civile, misto de jus e de faz, in penetralibus Pontificum, elegiam os senadores e magistrados para altos postos e os sacerdotes da religião pagã, monopolizando o Pontificado até meados do $3^{\circ}$ século a.C. As terras muitas vezes eram açambarcadas pelos patrícios, o dinheiro por eles manipulado a seu bel prazer em empréstimos extorsivos, objeto de vasta legislação controladora do foenus unciarum. Reagir contra todo esse poderio foi tarefa da plebe, numa luta que durou séculos, plena de episódios interessantes e heróicos. E às vezes os líderes reformadores surgiram do próprio patriciado, como ocorreu no século II a. C, com Tibério e Caio Graco". MEIRA, Silvio A. B. Legislação agrária romana. In: Novos e velhos temas de direito. 1. ed. Rio de Janeiro: Forense, 1973. p. 49.

${ }^{290}$ CRETELLA JÚNIOR, José. Curso de direito romano. 4. ed. Rio de Janeiro: Forense, 1970. p. 269.

${ }^{291}$ AZEVEDO, Álvaro Villaça. Proposta de classificação da responsabilidade objetiva: pura e impura, cit., p. 8.
} 
datum -, i.e., prejuízo causado à coisa alheia, delito que, à semelhança do furto empobrece a vítima, sem no entanto enriquecer o seu autor". ${ }^{292}$

A evolução dessa espécie de responsabilidade civil culminou com a releitura da palavra iniuria que, originariamente, correspondia ao dano contra a lei e que, mais tarde, pelos jurisconsultos foi-lhe apregoado outro sentido, qual seja, culpabilidade do causador da lesão. Passou-se a exigir que o prejuízo causado, o fosse dolosa ou culposamente, sendo imputável, outrossim, a negligência mais leve. ${ }^{293}$

Dessa forma, para que surgisse o damnum iniuria datum, de acordo com a Lei Aquilia, eram imprescindíveis três requisitos: a iniuria, que se traduzia na ocorrência do dano de maneira contrária ao direito; a culpa, que inicialmente se expressava em um ato comissivo doloso ou culposo e, posteriormente, em razão das inúmeras hipóteses que ficavam irressarcidas passou-se a considerar o ato omissivo também e, por fim, o damnum que representava a ocorrência de lesão perpetrada diretamente à coisa em virtude de ação do agente. ${ }^{294}$ Não obstante, é imperioso reconhecer que há divergência na doutrina, com relação à imprescindibilidade da culpa perante a Lei Aquilia, como requisito indispensável ao direito à reparação do prejuízo ocasionado. ${ }^{295}$

No que tange à responsabilidade civil dos pais, na época do Direito Romano, Cretela Júnior aduz que:

"No direito romano, era o pai que, na qualidade de responsável, teria que
arcar com o dano causado pelo filho ou pelo escravo, salvo se optasse por
abandoná-los à mercê do prejudicado em razão do instituto do abandono
noxal (noxa, ae, culpa, prejuízo; noxalis, e, prejudicial; nocere
prejudicar, causar dano)".

É interessante notar que não se exigia a culpa do pater para que surgisse tal responsabilidade. Seria, portanto, um risco pelo fato de manter terceiros sob sua guarda. Nos direitos arcaicos e no direito romano antigo, a responsabilidade do pater em relação a seus filhos tinha fundamento na idéia de solidariedade familiar e não na presunção de culpa

\footnotetext{
${ }^{292}$ CRETELLA JÚNIOR, José. op. cit., p. 269; neste mesmo sentido ver: ALVES, José Carlos Moreira. Direito romano, cit., p. 589.

${ }^{293}$ MARKY, Thomas. Curso elementar de direito romano. São Paulo: Bushatsky, 1971. p. 158.

${ }^{294}$ ALVES, José Carlos Moreira. Direito romano, cit., p. 590.

${ }^{295}$ LIMA, Alvino. Da culpa ao risco, cit., p. 14.

${ }^{296}$ CRETELLA JÚNIOR, José. op. cit., p. 223.
} 
advinda de uma deficiente fiscalização da educação (culpa in vigilando), como sustentou por um longo período a teoria clássica da responsabilidade civil. ${ }^{297}$

Nesse caso, é o grupo familiar que "responde" por todos os atos praticados por seus membros. O direito romano primitivo, como bem precisou Munir Karam, não tinha no elemento culpa a fundamentação da responsabilidade: satisfazia-se tão somente com o prejuízo e com o nexo de causalidade. ${ }^{298}$

$\mathrm{Na}$ fase mais antiga da responsabilidade civil dos pais no direito romano, vale ressaltar que o genitor exercia o direito de vida e morte (ius vitae ac necis) sobre os seus próprios filhos, o pater era o único sujeito de direitos patrimoniais, sendo que tudo dependia dele.

Todo delito que o filho praticasse deveria ser indenizado por seu genitor que detinha os direitos patrimoniais. ${ }^{299}$ Como a idéia da culpa não era conhecida, o fundamento da responsabilidade se exauria nos elementos: dano e nexo causal. Conclui-se, portanto, que a responsabilidade era, destarte, objetiva.

Realizado o delito, duas opções surgiam para o pater famílias para livrar-se do débito derivado do dano cometido pelo seu dependente: ou indenizava a vítima pelo seu prejuízo, ou abandonava o filho culpado à parte lesada, operando a noxae deditio (Gai.4,75.), poder posteriormente abolido por Justiniano (Inst. 4,8,7.). Assim, uma vez que o filho não possuía patrimônio próprio, o seu pai poderia entregá-lo, deixando-o sob a sujeição da vítima de modo a se tornar seu escravo, sendo que tudo que adquirisse integraria o patrimônio do dominus .

Aqui, pode-se vislumbrar um dado essencial, deixado pelo direito romano e que vai, de certa maneira, fundamentar e justificar a responsabilidade paterna no decorrer dos séculos. Uma vez que o filho é completamente dependente do pai é este, e não aquele, que assume o dever de indenizar o dano.

Na fase republicana, não obstante os magistrados tivessem tentado minimizar os poderes excessivos da patria potestas, o pater familias conservava, ainda, o direito de vida e de morte sobre os filhos, sendo imperioso relatar que a responsabilidade continuava

\footnotetext{
${ }^{297}$ CARBONNIER, Jean. Droit civil: les obligations. Paris: PUF, 2000. t. 4, p. 435.

${ }^{298}$ KARAM, Munir. op. cit., v. 65, p. 393.

${ }^{299}$ ROCHA, J. V. Castelo Branco. op. cit., p. 23.
} 
derivando exclusivamente do prejuízo, subsistindo a responsabilidade sem culpa, ou seja, prevalecia a idéia da responsabilidade objetiva. ${ }^{300}$

No entanto, sobreleva ressaltar que a noxae deditio, no período em debate, deixou de ser instrumento de vingança para se tornar meio de reparação pecuniária.

Com o reconhecimento, na época clássica, da possibilidade do filho-família se defender, evitando a noxae datio, e, igualmente, de ter patrimônio próprio (decorrente de herança, pecúlio ou emancipação), passou-se a admitir a idéia da responsabilização de caráter pessoal, sem interferência paterna. ${ }^{301}$ "No direito pós-clássico passa então o filius familias a ser diretamente responsável por danos praticados a terceiros e a poder se obrigar por contratos". 302

Com efeito, é mister reconhecer que, desde o início do instituto em discussão no direito romano, tem-se como justificativa principal a necessidade de compensar a vítima que sofreu um dano, recaindo a responsabilidade sobre o detentor de potencialidade patrimonial, qual seja, o pater familias, haja vista a incapacidade do próprio causador do dano de ressarcir o prejuízo ocasionado em razão da inexistência de patrimônio particular para tanto. ${ }^{303}$

É inegável, no entanto, que o avanço do instituto da responsabilidade civil extracontratual ou aquiliana, no direito romano, operou-se a partir da introdução do elemento subjetivo da culpa, contra o objetivismo do direito primitivo, eliminando-se do direito a idéia de pena, para substituí-la pela de reparação do prejuízo ocasionado. ${ }^{304}$

Com efeito, a culpa, ${ }^{305}$ sem dúvida alguma representou, em um dado momento histórico, a evolução do instituto da responsabilidade civil, vez que através dela obtinha-se

\footnotetext{
${ }^{300}$ LEITE, Eduardo de Oliveira. Grandes temas da atualidade: responsabilidade civil. Rio de Janeiro: Forense, 2006. v. 6, p. 89.

${ }^{301}$ Id., loc. cit.

${ }^{302}$ KARAM, M. Apud LEITE, Eduardo de Oliveira. Grandes temas da atualidade: responsabilidade civil, cit., p. 89.

${ }^{303}$ KARAM, Munir. op. cit., v. 65, p. 394.

${ }^{304}$ Id. Ibid., p. 16. Nas lições de Cristián Aedo Barrena é possível encontrar também o nexo de causalidade entre a conduta e o dano como um dos requisitos do delito de acordo com a Lex Aquilia. AEDO BARRENA, Cristián. op. cit., p. 317.

${ }^{305}$ Nas lições de Pontes de Miranda, tem-se que: "A culpa consiste na ligação, no nexo causal, psicofísico, entre o fato externo, contrário ao direito, ou não, e o sujeito. Supõe-se, como essencial, o voluntas, o ter-se querido, ou o ter-se procedido sem o cuidado necessário, para que o fato não se desse. A contrariedade ao direito, o ir contra o conteúdo da regra jurídica, não é elemento da culpa. É elemento da ilicitude do ato: contrariedade a direito mais culpa igual a ilícito". PONTES DE MIRANDA, Francisco Cavalcanti. Tratado de direito privado. Rio de Janeiro: Borsoi, 1966. t. 53, p. 48.
} 
um liame lógico e razoável de atribuibilidade entre a conduta praticada pelo agente e a modificação do mundo exterior por ela ocasionada. Por intermédio dela tornou-se possível a individualização da conduta danosa e, por conseguinte, do sujeito merecedor de sanção.

O reflexo dessa estrutura desenvolvida no direito romano foi percebido com mais ênfase, quando o legislador francês, seguindo a tradição de seu direito e as lições de Domat e Pothier, incorporou, ao art. 1382, do Código Napoleão, a responsabilidade aquiliana com fundamento na culpa comprovada e efetiva. ${ }^{306}$

Destarte, foi essa concepção, solidificada no princípio geral da necessidade da perquirição da culpa para o surgimento do dever de indenizar, que se espalhou para os códigos civis do século passado, incluindo o Código Bevilaqua que, em seu art. 159, trouxe a consagrada regra da responsabilidade aquiliana clássica, ou seja, fundamentada na idéia de culpa. ${ }^{307}$

Assim, são pressupostos da responsabilidade civil clássica: conduta voluntária do agente; o dano; ${ }^{308}$ o nexo de causalidade e o elemento subjetivo (dolo ou culpa). ${ }^{309}$ É necessário reconhecer, no entanto, que o elemento subjetivo culpa, em sentido lato, não é, hodiernamente, requisito imprescindível para a eclosão do dever de indenizar perante o nosso sistema, porquanto, como se verá, há previsão expressa em leis esparsas, micro sistemas e no próprio Código Civil, no artigo 927, parágrafo único, da responsabilidade objetiva, ou seja, independentemente de culpa.

É possível caracterizar o direito pré-codificado em três diferentes fases: na primeira, as Ordenações do Reino aplicavam o Direito Romano como subsidiário do direito pátrio, em decorrência da Lei da Boa Razão (Lei de 18 de agosto de 1769). Não se

\footnotetext{
${ }^{306}$ PONTES DE MIRANDA, Francisco Cavalcanti. Tratado de direito privado, cit., t. 53, p. 17-18.

${ }^{307}$ NORONHA, Fernando. Desenvolvimentos contemporâneos da responsabilidade civil, cit., p. 35.

${ }^{308}$ Impende destacar que, a necessidade da existência do elemento dano, em razão da flexibilização da forma de se interpretar o instituto da responsabilidade civil, já é debatida em sede de implementação dos princípios da precaução e da prevenção. LOPEZ, Teresa Ancona. Princípio da precaução e evolução da responsabilidade civil, cit., p. 133-140.

309“Na prática judicial, isto significava que a vítima de um dano precisava, além de evidenciar seu prejuízo, superar duas sólidas barreiras para obter indenização: (i) a demonstração da culpa do ofensor, e (II) a demonstração do nexo de causalidade entre a conduta culposa do ofensor e o dano. Estas duas barreiras prova da culpa e prova do nexo causal - chegaram a ser chamadas filtros da responsabilidade civil ou filtros da reparação, por funcionarem exatamente como óbices capazes de promover a seleção das demandas de ressarcimento que deveriam merecer a acolhida jurisdicional." SHREIBER, Anderson. Novos paradigmas da responsabilidade civil: da erosão dos filtros da reparação à diluição dos danos. 2. ed. São Paulo: Atlas, 2009. p. 11.
} 
pode olvidar que as Ordenações do Reino não deixavam claras as diferenças existentes entre a reparação, a pena e a multa.

Com a promulgação do Código Criminal de 1830, que inaugura a segunda fase, o estudo da responsabilidade civil se fortaleceu, haja vista a formação de regras no diploma mencionado que serviam de orientação para a sua análise.

Eram inimputáveis, para o Código Criminal de 1830, apenas os menores de 14 anos (art.10, parágrafo $1^{\circ}$ ), não obstante a sujeição de seus bens à satisfação do prejuízo ocasionado e a previsão da reparação cabal do dano no art. 22 , que assim dispunha: "A satisfação será sempre a mais completa que for possível e, no caso de dúvida, a favor do ofendido. Para esse fim, o mal que resulta à pessoa do ofendido será avaliado em todas as suas partes e conseqüências".

A Nova Consolidação de Carlos de Carvalho e a Consolidação de Teixeira de Freitas iniciam a terceira fase do direito pré-codificado, sendo que esta última tem como escopo desvincular a responsabilidade civil da criminal (a satisfação do dano causado pelo delito passou para o seu lugar próprio, que é a legislação civil).

Das Consolidações decorrem algumas disposições orientadoras da reparação do dano ex delicto. Assim: cogita da responsabilidade do delinquente, estabelece a necessidade de ser pedida a indenização por via de ação cível, estabelece a solidariedade dos co-delinqüentes e minudencia os diversos aspectos da reparação e liquidação do dano, entre outros aspectos.

"Lafayette ensinava-nos que a plenitude da capacidade civil advinda da
cessação da menoridade não vigorava em nosso direito pré-codificado,
pois sob a influência do direito romano mantinha-se o indivíduo sob a
tutela perpétua e assistência paterna; considerava-se que a maioridade,
por si só, não era hábil a atribuir a plenitude do exercício dos direitos; o
indivíduo mesmo maior, continuava sob o pátrio poder, que vinha a
cessar com o casamento, o estabelecimento comercial com economia
própria, o recebimento de ordens sacras, a colação de grau acadêmico, e
ainda por sentença judicial".

Não obstante o Código Civil de 1916 ter perfilhado a clássica teoria da culpa, é imperioso admitir que a teoria objetiva, muito antes da entrada em vigor do atual Código

\footnotetext{
${ }^{310}$ DINIZ, Maria Helena. Curso de direito civil brasileiro: teoria geral do direito civil. 24. ed., cit., p. 193.
} 
Civil, espraiou-se por vários setores da atividade por intermédio de leis especiais. ${ }^{311}$ Nesse sentido, vislumbra-se, exemplificativamente, o Decreto $n^{\circ} 2.681$, de 1912, que regulamenta a responsabilidade civil das estradas de ferro considerando o risco da atividade. No que tange ao acidente do trabalho, a Lei 6.367, de 19 de outubro de 1976, fundamentou-se no risco profissional e a indenização dos prejuízos causados aos trabalhadores passou a ser implementada desvinculada da análise da culpa, assim como ocorria com o Código Brasileiro do Ar (Decreto-lei 32, de 18 de novembro de 1966), que disciplinou, objetivamente, a responsabilidade civil das empresas aéreas, também baseado na teoria do risco da atividade explorada. A Lei 6.453, de 17 de outubro de 1977, da mesma forma, abraçando a teoria objetiva, regulamentou a responsabilidade civil por danos nucleares. A Lei $6138 / 81$, em seu artigo $14, \S 1^{\circ}$, consagrou a responsabilidade objetiva para os danos perpetrados no meio ambiente, em que mesmo aquele que exerce atividade lícita e licenciada, se causar dano, deve arcar com a indenização. ${ }^{312}$

Sobreleva ressaltar, ainda, que a sistemática prevista pelo Código Bevilaqua não elidiu, cabalmente, a adoção, mesmo que em alguns poucos casos, de responsabilidade objetiva. De fato, no seu artigo 1.529, concernente à obrigação imposta ao morador de casa de ressarcir danos ocasionados em razão de queda ou lançamento de coisas que dela advenham, resta clara a opção do legislador em acolher a responsabilidade independente de culpa. $^{313}$

No que tange à responsabilidade indireta ou por fato de terceiro, vale a pena mencionar que o pretendido no CC/1916 era que ela fosse subjetiva, todavia com presunção de culpa, a exemplo da codificação francesa (art.1384) e do BGB (art. 831), mas que, na tramitação, mercê de emenda no Senado (Emenda n.1.438), alterou-se essa

\footnotetext{
${ }^{311}$ Neste mesmo sentido assevera Alvino Lima que: "Do estudo sumário que acabamos de fazer, vê-se claramente que o legislador brasileiro consagrando a teoria da culpa, nem por isso deixou de abrir expções ao princípio, admitindo casos de responsabilidade sem culpa, muito embora não tivesse acompanhado, com mais amplitude, a orientação moderna de outras legislações, como seria de desejar". LIMA, Alvino. Da culpa ao risco, cit., p. 215.

${ }^{312}$ Álvaro Villaça Azevedo, ao discorrer a respeito da responsabilidade objetiva pura e impura assevera que: “ ...se, por um fato jurídico (tufão), um recipiente de ácido (instalado com toda a segurança) é arrastado a um rio, causando danos ecológicos, a obrigação de indenizar existe, como também por ato lícito, de uma empresa poluente, que está autorizada à sua atividade, dentro de certos parâmetros, controlados por órgãos públicos. Por exemplo, empresa poluidora, fiscalizada pela CETESB - Companhia Estadual de tecnologia de Saneamento Básico e de Defesa do Meio Ambiente. A indenização existe, portanto, tão somente, por causa da atividade de risco, conforme definido no $\S 1^{\circ}$ do art. 14 da lei 6.938/81, regulamentada pelo Dec. 88.351/83". AZEVEDO, Álvaro Villaça. Proposta de classificação da responsabilidade objetiva: pura e impura, cit.

${ }^{313}$ NORONHA, Fernando. op. cit., p. 33.
} 
expectativa inicial com relação à presunção de culpa dos pais pelos danos praticados pelos filhos menores e, outrossim, em face dos outros sujeitos elencados no artigo 1.521 do diploma em comento.

Agora, com o Código Civil de 2002, estabeleceu-se uma responsabilidade sem culpa por ato de terceiro, incluindo a responsabilidade dos pais pelos atos de seus filhos menores, o que ilide a possibilidade de qualquer dos responsáveis, uma vez demandado, procurar se eximir de seu dever indenizatório alegando que escolheu ou que vigiou bem, haja vista a adoção da responsabilidade objetiva.

É por demais sabido que essa espécie de responsabilidade surgiu da evolução do instituto da responsabilidade civil, que deixou a presunção de culpa de lado para perfilhar a responsabilidade civil, independentemente desse elemento subjetivo.

\subsection{Da responsabilidade civil objetiva}

Conforme já explanado acima, em razão da influência do Direito Francês, ${ }^{314}$ o Código Civil de 1916 perfilhou a teoria subjetiva para estabelecer os elementos necessários à deflagração da responsabilidade civil consagrando, conseguintemente, a culpa como um de seus pressupostos. ${ }^{315}$

Não obstante o legislador de 1916 tenha optado pela estrutura da teoria subjetiva como fundamento da responsabilidade civil, é possível vislumbrar algumas situações, previstas em leis especiais ou no próprio Código de 1916, em que se partiu do pressuposto

\footnotetext{
314“"Na esteira do art. 1.382 do Código francês, inúmeros diplomas civilistas do Ocidente adotaram a idéia de que a responsabilização civil de um agente causador de danos, em regra, só poderia concretizar-se mediante a existência do elemento subjetivo culpa (aqui designada em seu sentido lato, abrangendo também o dolo)... O Código brasileiro de 1916 adotou tal posicionamento em sua parte geral, no art. 159, o que também ocorre no Código Civil espanhol, em seu art. 1.902, no uruguaio (art. 1.319) e no português (art. 483). Todos esses diplomas, e outros tantos, exigem como regra geral a prova de que o agente tenha agido com culpa, para só então permitir que a vítima receba indenização.” NICOLAU, Gustavo Rene. Efetiva aplicação da teoria do risco no Código Civil de 2002. In: DELGADO, Luiz Mário; ALVES, Jones Figueirêdo (Coords.). Novo Código Civil: questões controvertidas: responsabilidade civil. São Paulo: Método, 2006. p. 225. (Série Grandes Temas de Direito Privado, 5).

${ }^{315}$ AMARAL NETO, Francisco dos Santos. Responsabilidade civil. In: FRANÇA, Rubens Limongi (Org.). Enciclopédia Saraiva do Direito. São Paulo: Saraiva, 1977. v. 65, p. 351; LIMA, Alvino. Da culpa ao risco, cit., p. 174-175; Neste sentido também: "Não é novidade que o Código Civil anterior e a legislação brasileira como um todo adotou, com algumas exceções, a responsabilidade subjetiva, não prescindindo da culpabilidade como parte integrante do ato ilícito". STOCO, Rui. A responsabilidade civil. In: FRANCIULLI NETTO, Domingos; MENDES, Gilmar Ferreira; MARTINS FILHO, Ives Granda da Silva (Coords.). O novo Código Civil: estudos em homenagem ao Prof. Miguel Reale. São Paulo: LTr, 2003. p. 811.
} 
da insuficiência da resposta, conferida à vitima, por esse modelo, ${ }^{316}$ no sentido de salvaguardar determinados interesses, estabelecendo-se, consequentemente, a teoria objetiva fundamentada no risco da atividade. ${ }^{317}$

Deveras, o Código Civil de 1916 sintetizou um desenvolvimento advindo do direito romano $^{318}$ e consagrou, em seu bojo, soluções que, no seu tempo eram suficientes para atender aos anseios sociais da época no que tange ao instituto da responsabilidade civil. Ocorre que essas soluções, proclamadas pelo sistema, passaram a ser insuficientes e anacrônicas ante o desenvolvimento histórico e tecnológico por que passou a sociedade. ${ }^{319}$

Com efeito, a definição clássica de culpa fundamentada no aspecto psicológico, como será analisada, cedeu espaço para a sua objetivação, culminando com a eliminação do elemento subjetivo da responsabilidade extracontratual em muitas situações. Então, a corrente objetivista engajou-se em desvincular a obrigação de indenizar da concepção da culpa. Saleilles, o maior expositor dessa doutrina, insurgiu-se contra a culpa, e fundamentou o ressarcimento no fato danoso, ou seja, no seu conceito material. Josserand buscou conciliar esse tipo de responsabilidade sem culpa com o Código Napoleão, não obstante estivesse este vinculado à teoria subjetivista. Nesse caso, muitos escritores encaminharam-se no mesmo sentido, buscando mudar a equação para uma obrigação indenizatória, fundada no prejuízo e na autoria do evento danoso, sem mencionar a questão

\footnotetext{
316“"A responsabilidade civil baseada na imputação culposa se assemelha a um edifício dotado de portas difíceis de serem abertas: somente quem demonstre a culpa, pode obter a reparação. Deste modo, há um importante custo de acesso: necessita-se procurar um bom advogado, provas e estar frente a danos que resultem de condutas suscetíveis de um juízo condenatório. A imputação objetiva amplia o campo da reparação, de vez que não só aqueles que demonstrem a culpa podem obtê-la, mas também aqueles que não estejam em condições de fazê-lo, seja por insuficiência de meios, ou porque tenham sido prejudicados por coisas ou atividades perigosas". LORENZETTI, Ricardo. Fundamentos do direito privado, cit., p. 96-97.

${ }^{317}$ LIMA, Alvino. Da culpa ao risco, cit., p. 178-179; Nas lições de Caio Mario: "Campo fértil aos debates e aos litígios, a responsabilidade civil tem procurado libertar-se do conceito tradicional de culpa. Esta é, às vezes, constritora, e embaraça com freqüência a expansão da solidariedade humana. A vítima não consegue, muitas vezes, vencer a barreira processual, e não logra o ressarcimento. É verdade que a tendência é o alargamento do conceito de culpa, e conseqüente ampliação do campo da responsabilidade civil, ou do efeito indenizatório.” PEREIRA, Caio Mário da Silva. Instituições de direito civil. Contratos. Declaração unilateral de vontade. Responsabilidade civil. 7. ed. Rio de Janeiro: Forense, 1984. v. 3, p. 393. PONTES DE MIRANDA, Francisco Cavalcanti. Fontes e evolução do direito civil brasileiro. 2. ed. Rio de Janeiro: Forense, 1981. p. 331.

${ }^{318}$ Silvio Rodrigues, em seu livro editado ainda na vigência do Código Civil de 1916, asseverou que: "Como apontei, a responsabilidade se baseia na idéia de culpa. Só provada a culpa do agente é que emerge a necessidade de reparar o dano. Tal idéia, tradicional no direito romano, inspirou as várias legislações, inclusive a nossa, que consagrou o princípio no art. 159 do Código Civil." RODRIGUES, Silvio. Direito civil: parte geral, cit., v. 1, p. 307.

${ }^{319}$ NORONHA, Fernando. op. cit., p. 33. FERNÁNDEZ CRUZ, Gastón; LEÓN HILARIO, Leysser. La reedificación conceptual de la responsabilidad extracontratual objetiva. Revista de la Facultad de Derecho Pontifícia Universidad Católica del Perú, Lima, n. 58, 2004. p. 11.
} 
da imputabilidade, sem perquirir se ocorreu ou não um erro de conduta, não se indagando acerca da antijuridicidade da ação. ${ }^{320}$

Realmente, o extraordinário aumento dos danos, cumulado com a indefinição de suas causas, a necessidade de se tutelar a vítima, proporcionando-lhe a indenização pelo prejuízo sofrido, a complexidade da prova da culpa nos acidentes, em razão dos inventos desconhecidos em sua essência, provocaram os juristas que passaram a refletir a respeito de um novo fundamento para a responsabilidade civil. ${ }^{321}$

De fato, é importante reconhecer que os motivos da evolução da responsabilidade civil subjetiva para objetiva relacionam-se, inicial e primordialmente, com a Revolução Industrial $^{322}$, iniciada na Inglaterra do século XVIII, e o consequente aumento dos riscos a que as pessoas passaram a estar sujeitas, fato este que acresceu as demandas para a devida indenização. ${ }^{323}$ Vale dizer, a complexidade dos prejuízos causados, em uma sociedade agrária, em que as relações de trocas econômicas se caracterizavam pela simplicidade, era bem menor, se comparada com os danos ocorridos em uma sociedade pós-industrial com desenvolvimento tecnológico bem avançado. ${ }^{324}$

\footnotetext{
${ }^{320}$ PEREIRA, Caio Mário da Silva. Instituições de direito civil. Contratos. Declaração unilateral de vontade. Responsabilidade civil, cit., v. 3, p. 394. De acordo com o escólio de Gastón Fernández Ruz e Leysser Leon Hilário, a respeito do desenvolvimento da objetivação da responsabilidade, Raymond Saleilles (1855-1912) trabalhara mais com a aplicação da responsabilidade objetiva com fundamento no risco profissional, enquanto Louis Joserrand (1868-1941) foi responsável pelo desenvolvimento da responsabilidade objetiva com fundamento no risco criado. A primeira se opera por meio da objetivação da responsabilidade para administrar os danos produzidos pelas grandes fábricas. A segunda, mais abrangente, preconiza que quem gera um risco deve indenizar o dano dele advindo. FERNÁNDEZ CRUZ, Gastón; LEÓN HILARIO, Leysser. op. cit., p. 32.

${ }^{321}$ LIMA, Alvino. Da culpa ao risco, cit., p. 86-87. "Na modernidade tardia, a produção social de riqueza é acompanhada sistematicamente pela produção social de riscos. Consequentemente, aos problemas e conflitos distributivos da sociedade da escassez sobrepõem-se os problemas e conflitos surgidos a partir da produção, definição e distribuição de riscos científico-tecnologicamente produzidos”. BECK, Ulrich. op. cit., p. 23.

322،"Para melhor compreender as razões inspiradoras da teoria que fundamentou a responsabilidade objetiva, faz-se necessário conhecer os fatos históricos que nortearam os seus mentores teóricos. O quadro da época é o da Revolução Industrial, em que o domínio da produção é sistema predominante da sociedade daquele tempo. Sintetizando aquele momento histórico, disse Burns que a Revolução Industrial compreendeu: $a$ ) a mecanização da indústria e da agricultura; $b$ ) a aplicação da força motriz à indústria; $c$ ) o crescimento do sistema fabril; $d$ ) o sensacional desenvolvimento dos transportes e das comunicações; e $e$ ) o considerável acréscimo do controle capitalista sobre quase todos os ramos da atividade econômica". ALONSO, Paulo Sergio Gomes. Pressupostos da responsabilidade civil objetiva. São Paulo: Saraiva, 2000; Para Anderson Schreiber “... os acidentes trazidos pela Revolução Industrial eram, ao contrário do que sucedia nos séculos anteriores, inteiramente despersonalizados, anônimos, provocados muitas vezes por pequenas distrações ou falhas praticamente imunes a constatação". SHREIBER, Anderson. op. cit., p. 18.

${ }^{323}$ NORONHA, Fernando. op. cit., p. 35.

${ }^{324}$ De acordo com os ensinamentos de Gastón Fernandes Cruz e Leysser León Hilário: “...el clásico principio en virtud del cual 'no hay responsabilidad sin culpa' se adaptaba perfectamente a las exigencias de una sociedad como del siglo XVIII, de intercambios económicos relativamente modestos y carente de un despliegue técnico apreciable, en el que las principales fuentes de peligro continuaban siendo representadas
} 
Destarte, a evolução natural desse fenômeno social, isto é, a Revolução Industrial, ocasionou o progresso da tecnologia, ${ }^{325}$ a busca incessante pelo lucro e o surgimento de empresas poderosas que passaram a impor as suas vontades, em detrimento das pessoas físicas, aproveitando-se de suas forças econômicas.

Nesse contexto histórico, a responsabilidade civil objetiva encorpou-se, ou seja, a partir do momento em que as pessoas passaram a ficar cotidianamente expostas a situações de perigo, em virtude do grande desenvolvimento tecnológico, ocasionando a submissão dos sujeitos a riscos, sem que obtivessem, entretanto, a necessária indenização em caso de danos por não serem eficientes os meios legais até então existentes sobre a responsabilidade civil. ${ }^{326}$

Neste diapasão, é mister explicitar, ainda, a importante contribuição da doutrina e da jurisprudência francesas para o desenvolvimento do instituto em testilha. De fato, no ano de 1885, na França, a Corte Suprema impunha o dever de indenizar as vítimas, independentemente de culpa, pelos danos proporcionados por animais, restringindo, demasiadamente, as possíveis causas de exoneração da responsabilidade do guarda ou proprietário do animal. $^{327}$

Posteriormente, em 1896, a decisão Teffaine, que se referia à morte acidental de um operário, em virtude da explosão de um rebocador a vapor, foi vista por Salleiles e Joserand, defensores da teoria do risco, como um avanço sintomático e significativo em

por los animales o por los objetos caídos de las casas. En una sociedad no industrializada, en la que los hombres convivían com los animales, los mayores riesgos, aun los citadinos, estaban representados por el no ser mordido por un cerdo del corral de un vecino o no ser arrollado por una carroza jalada por caballos. El criterio jurídico de imputación por culpa era, ciertamente, el 'adecuado para regular el problema de la responsabilidad civil de las escasas hipótesis de daño de sociedades no industrializadas ni mecanizadas: además, la regla jurídica se confundía con la regla moral que indicaba la conveniencia de basar la responsabilidad en uma evaluación del comportamiento subjetivo del agente'”. FERNÁNDEZ CRUZ, Gastón; LEÓN HILARIO, Leysser. op. cit., p. 12.

${ }^{325} \mathrm{Em}$ seu livro, Pressupostos da responsabilidade civil objetiva, cit., Paulo Sergio Gomes Alonso disserta que a Revolução Industrial processou-se de maneira assaz intensa, ocasionando desenvolvimento nas áreas de transporte, com o aparecimento de novos meios de locomoção; comunicação, com o surgimento do telefone, telégrafo, rádio etc. Ademais, de acordo com o autor, a Revolução Industrial proporcionou o surgimento da luz elétrica, da máquina de escrever, da refrigeração artificial, da fotografia, sendo que todos esses fatores proporcionaram uma melhor qualidade de vida para as pessoas. Tudo isso ocasionou uma maior produtividade por menor preço, permitindo a aquisição de produtos por um número bem maior de sujeitos. Não obstante, "a utilização de máquinas mais sofisticadas e a superprodução eram fontes de desempregos e a convivência e sujeição ao perigo era cada vez mais iminente, em face do uso das novas tecnologias". ALONSO, Paulo Sergio Gomes. op. cit., p. 34-35.

${ }^{326}$ ALONSO, Paulo Sergio Gomes. op. cit., p. 36.

${ }^{327}$ HIRONAKA, Giselda Maria Fernandes Novaes. Responsabilidade pressuposta: evolução de fundamentos e de paradigmas da responsabilidade civil na contemporaneidade. In: DELGADO, Luiz Mário; ALVES, Jones Figueirêdo (Coords.). Novo Código Civil: questões controvertidas. Responsabilidade Civil. São Paulo: Método, 2006. p. 212. (Série Grandes Temas de Direito Privado, v. 5). 
prol da responsabilidade fundamentada no risco. Entrementes, é curial esclarecer que a respeito da mesma decisão, os irmãos Mazeud vislumbraram ainda a responsabilidade subjetiva como seu fundamento. ${ }^{328}$

Apenas trinta e cinco anos mais tarde, em 1930, uma outra decisão da Corte de Cassation, conhecida por "l'arrêt Jand Heur, ratificou a proposição, em acidentes de veículos, deste caminho percorrido em busca da noção de garantia social, por meio de uma releitura do art. $1.384,1^{\mathrm{a}}$ alínea, do $\mathrm{CC}$ francês, "a expressão présomption de faute [déjà inconciliable avec la jurisprudence] por présomption de responsabilité, independentemente de culpa. ${ }^{329}$

Portanto, com este cenário de vultoso avanço tecnológico, como aduziu Alvino Lima, percebeu-se que o elemento subjetivo dificultava e, porque não dizer, impossibilitava a obtenção de indenização por parte daquele que sofresse algum prejuízo, uma vez que a demonstração da culpa tornou-se, na sociedade industrializada e perigosa, extremamente complexa. ${ }^{330}$

Deveras, além da incorporação do risco na dinâmica de nossa sociedade contemporânea, é possível vislumbrar, também, a massificação da produção, do consumo, da comunicação, do contrato de massa, o que evidencia a interdependência entre as pessoas em um nível extremamente alto e complexo. Tudo isso é somado à capacidade das organizações privadas alcançarem, com absoluta força impositiva, os sujeitos de direito que, muitas vezes, não têm o poder para resistir eficazmente a essas imposições. Assim, o acréscimo do risco e o aumento dessas relações sociais desprovidas de pessoalidade, ou

\footnotetext{
${ }^{328}$ De acordo com a referida autora, o caso era o seguinte: "Dizia respeito à morte acidental de um operário, em decorrência de uma explosão num rebocador a vapor. A Corte Suprema desencadeou, à época, um novo princípio segundo o qual a pessoa era responsável pela coisa que lhe pertencia. O proprietário do rebocador não pôde, portanto, exonerar-se da responsabilidade, provando a culpa do construtor do rebocador, e indenizou a viúva e as crianças do operário morto. Esta decisão fundamental costuma ser referida como o primeiro passo em direção, pela via jurisprudencial francesa, da noção de risco social, porque absorveu a idéia de que, com o progresso técnico e o avanço de enigmas perigosos, o exclusivo campo de atuação da culpa individual estava diminuindo". HIRONAKA, Giselda Maria Fernandes Novaes. Responsabilidade pressuposta: evolução de fundamentos e de paradigmas da responsabilidade civil na contemporaneidade, cit. p. 212.

${ }^{329}$ HIRONAKA, Giselda Maria Fernandes Novaes. Responsabilidade pressuposta: evolução de fundamentos e de paradigmas da responsabilidade civil na contemporaneidade, cit. p. 212. FERNÁNDEZ CRUZ, Gastón; LEÓN HILARIO, Leysser. op. cit., p. 28.

${ }^{330}$ Neste diapasão são as lições de Paulo Sergio Gomes: “A prova era simplesmente uma forma limitativa e proibitiva de obter o ressarcimento do dano sofrido em determinadas situações, como no caso do operário que sofreu um acidente de trabalho; do passageiro que morreu em consequiência da queda do avião que o transportava; de outro passageiro de trem, que faleceu após ter sido lançado para fora do vagão, e de outras centenas de situações em que a vítima - ou os seus dependentes, pelo falecimento desta - não tinha como fazer a prova da culpa do agente, e o resultado era um só, o não ressarcimento dos danos sofrido por ela, criando situações dramáticas pelo infortúnio sofrido”. ALONSO, Paulo Sergio Gomes. op. cit., p. 38.
} 
seja, anônimas, demonstrou a deficiência da responsabilidade civil subjetiva e a necessidade de se procurar alternativas para a culpa. Destarte, hodiernamente, o ponto fulcral da responsabilidade passou a ser a necessidade imperiosa de reparação do dano, prescindindo-se da análise da conduta em si e do elemento subjetivo. ${ }^{331}$

O incremento da responsabilidade civil, em razão da Revolução Industrial e as suas supracitadas consequências na vida das pessoas, expressa-se, nas lições de Fernando Noronha, em um triplo fenômeno que se traduz por meio da expansão dos danos indenizáveis, pela coletivização e objetivação da responsabilidade. ${ }^{332}$

Em suas lições, Fernando Noronha afirma que o primeiro fenômeno consistente na ampliação dos danos suscetíveis de reparação sintetiza-se na consolidação do ideal compensatório do dano extrapatrimonial, além da solidificação da tutela dos danos transindividuais, o que exterioriza a aspiração da sociedade em conceber uma responsabilidade civil mais protetiva à pessoa. O fenômeno da coletivização da responsabilidade se expressa na maior participação, no mercado econômico, das empresas seguradoras, com o objetivo de diluir o prejuízo daquele que comete o ato ilícito e deve indenizar; no surgimento de uma seguridade social mais eficaz e no aparecimento da responsabilidade grupal. O último fenômeno, o da responsabilidade objetiva, traduz o declínio da busca do elemento subjetivo para a deflagração do dever de reparação. ${ }^{333}$

Dessa forma, e após todo o desenvolvimento narrado, a solução encontrada pelo sistema jurídico contemporâneo foi a de reconhecer e consagrar a responsabilidade independentemente do elemento subjetivo, é dizer, objetiva, facilitando a obtenção de indenização por parte da vítima, ${ }^{334}$ suprimindo-lhe, em muitos casos, o ônus de provar ${ }^{335}$ a culpa do causador da lesão, bastando a existência do dano e do nexo de causalidade. Ou

\footnotetext{
${ }^{331}$ PASSOS, J. J. Calmon de. O imoral nas indenizações por dano moral. Jus Navigandi, Teresina, ano 6, n. 57, jul. 2002. Disponível em: <http://jus2.uol.com.br/doutrina/texto.asp?id=2989>. Acesso em: 5 jun. 2010. ${ }^{332}$ NORONHA, Fernando. op. cit., p. 35; CHINELATO, Silmara Juny de Abreu. op. cit., p. 584.

${ }^{333}$ NORONHA, Fernando. op. cit., p. 35.

${ }^{334}$ De acordo com o escólio de Aguiar Dias: "Como o antigo fundamento da culpa não satisfaz, outros elementos vêm concorrer para que a reparação se verifique, mesmo em falta daquela". DIAS, José de Aguiar. Da responsabilidade civil, cit., v. 1, p. 16; Alvino lima, neste sentido, afirmou que: "Foram os próprios defensores da teoria subjetiva que, verificando a impossibilidade de resolver o problema da reparação dos danos, nos acanhados limites da culpa subjetiva, exigindo a imputabilidade moral, materializaram a noção de culpa”. LIMA, Alvino. Da culpa ao risco, cit., p. 217.

335، Ônus processual é a situação em que a prática de determinado ato leva a parte a obter determinado efeito processual ou impedir que ele ocorra. O conceito de ônus não equivale ao de dever. Dever é obrigação, a que, no outro pólo da relação jurídica, corresponde um direito". GRECO FILHO, Vicente. Direito processual civil brasileiro. 15. ed. São Paulo: Saraiva, 2002. v. 2, p. 12.
} 
seja, o fundamento para a eclosão do dever de reparar o prejuízo passou a ser a teoria do risco. $^{336}$

Entretanto, é imperioso reconhecer, ainda que a título de finalização do esboço histórico, que essa mudança estrutural no conjunto de elementos necessários para o surgimento da responsabilidade civil não se deu de uma hora para outra, elidindo-se a culpa e colocando em seu lugar a responsabilidade objetiva.

Não. Pode-se vislumbrar no próprio sistema jurídico brasileiro uma evolução vagarosa, no sentido de desprender-se paulatinamente da culpa, passando-se para o instituto denominado, por alguns autores, de responsabilidade objetiva indireta, que nada mais é senão a presunção relativa de culpa em algumas situações, ${ }^{337}$ até chegar-se à responsabilidade objetiva propriamente dita. ${ }^{338}$

Com efeito, o art. 927, parágrafo único, do Código Civil de 2002, sintetizou todo esse progresso jurídico explicitado e perfilhou a teoria objetiva da responsabilidade civil, ao estabelecer que: "haverá obrigação de reparar o dano, independentemente de culpa, nos casos especificados em lei, ou quando a atividade normalmente desenvolvida pelo autor do dano implicar, por sua natureza, risco para os direitos de outrem". 339

\footnotetext{
336“"A tendência à objetivação da responsabilidade civil atende à sociedade pós-moderna, sociedade de massa e globalizada, caracterizada pelos riscos da produção e do desenvolvimento, nos quais se inclui a tecnologia, que tornam mais vulneráveis as pessoas, possíveis vítimas." CHINELATO, Silmara Juny de Abreu. op. cit., p. 588.

337،“As presunções de culpa consagradas na lei, invertendo o ônus da prova, veio melhorar a situação da vítima, criando-se a seu favor uma posição privilegiada. Tratando-se, contudo, de presunções juris tantum, não nos afastamos do conceito de culpa da theoria clássica, mas apenas derrogamos um princípio dominante em matéria de prova. Tais presunções são, em geral, criadas nos casos de responsabilidade complexas, isto é, das que decorrem de fatos de outrem ou do fato das coisas inanimadas. Fixadas por lei a presunção juris tantum, o fato danoso é considerado, em si mesmo, um fato culposo e como tal determinará a responsabilidade do autor, si este não provar a ausência de causa estranha causadora do dano, como a força maior, o caso fortuito, a culpa da própria vítima ou o fato de terceiro". LIMA, Alvino. Da culpa ao risco, cit., p. 53-54.

338، O Código Civil Brasileiro (1916), através do art. 159, consagrou a responsabilidade subjetiva como regra geral no sistema privado brasileiro, a reclamar reparação contra todos os atos culposos que causem dano injusto. Pouco a pouco, contudo, percebeu-se a insuficiência da técnica subjetivista, também chamada aquiliana, para atender a todas as hipóteses em que os danos deveriam ser reparados. Procedeu-se, primeiramente, por obra da jurisprudência, a uma expansão da responsabilidade subjetiva para hipóteses em que se presumia a culpa do agente. Em etapa sucessiva, veio o legislador a regular, mediante expressa previsão legislativa, hipóteses em que a reparação se impõe independentemente da conduta culposa do responsável, associando a reparação não já a seu comportamento mas ao risco provocado pela atividade da qual resultou o dano". TEPEDINO, Gustavo. Temas de direito civil. 2. ed. Rio de Janeiro: Renovar, 2001. p. 175.

${ }^{339}$ Fábio Ulhoa Coelho propõe uma divisão conceitual entre a responsabilidade objetiva advinda da lei e contida na primeira parte do parágrafo único em comento, a que denomina de responsabilidade objetiva formal, e a responsabilidade objetiva haurida da atividade de risco e prevista na segunda parte do debatido dispositivo, que define como responsabilidade objetiva material. COELHO, Fábio Ulhoa. Curso de direito civil. São Paulo: Saraiva, 2004. v. 2, p. 342.
} 
No entanto, logo no início do capítulo que trata da responsabilidade civil, em seu artigo 927, o Código Civil de 2002 aduz que: “Aquele que, por ato ilícito (arts. 186 e 187), causar dano a outrem, fica obrigado a repará-lo". De acordo com esse preceito, deparamonos com a responsabilidade civil subjetiva, em sua cláusula geral.

Analisando-se apenas o caput desse artigo, poder-se-ia chegar a uma falsa conclusão de que o legislador continuaria adotando a teoria subjetiva para a deflagração da responsabilidade civil. No entanto, conforme relatado, a grande mudança legislativa é fruto do parágrafo único do aludido artigo.

Desse modo, hoje há previsão expressa de uma cláusula geral, prevendo a responsabilidade objetiva, baseada na teoria do risco, que vem dando e dará margem a discussões infindáveis no que tange a qual seria a teoria do risco perfilhada pelo Código Civil e seu real limite. Impende ressaltar, por oportuno, que no mesmo dispositivo legal a lei enuncia que o próprio Código Civil trouxe casos de responsabilidade objetiva previstos expressamente na lei.

É mister explicitar também que, por meio da introdução dessa regra ao sistema, surgiram dúvidas entre os doutrinadores acerca da espécie preponderante da responsabilidade civil, perfilhada pelo atual sistema Civil, havendo aqueles que entendem, majoritariamente, que a regra geral continua sendo a responsabilidade subjetiva. ${ }^{340}$

Contudo, há autores ${ }^{341}$ que chegam até a vislumbrar a derrocada da culpa e a consequente supremacia da responsabilidade objetiva, uma vez que a mencionada cláusula

\footnotetext{
340“'A teoria da culpa, resumida, com alguma arrogância, por Von Ihering, na fórmula 'sem culpa, nenhuma reparação', satisfez por dilatados anos à consciência jurídica, e é, ainda hoje, tão influente que inspira a extrema resistência oposta por autores insignes aos que ousam proclamar a sua insuficiência em face das necessidades criadas pela vida moderna, sem aludir ao defeito da concepção por si mesma". DIAS, José de Aguiar. Da responsabilidade civil, cit., v. 1, p. 43.

${ }^{341}$ De acordo com Martinho Garcez: "a noção de culpa, que parecia tão sólida, permitindo a Ripert assinalar que, durante todo o século XIX, os juristas não ousaram levantar qualquer dúvida sobre esse fundamento da responsabilidade, encontra-se, há cerca de meio século, submetido à crítica mais severa de que se tem notícia no mundo contemporâneo. E não será por outra razão que se dá a esse movimento o título de crise da responsabilidade civil’. GARCEZ NETO, Martinho. Responsabilidade civil no direito comparado. Rio de Janeiro: Renovar, 2000. p. 86.

Para Gustavo Tepedino, a complexidade e o desenvolvimento tecnológico "impulsionaram a firme tendência legislativa que, nos últimos cinqüenta anos, tem transformado a dogmática da responsabilidade civil em todo o mundo, fomentando, na Europa, inúmeras leis disciplinadoras da responsabilidade civil e, nos Estados Unidos, a abertura do caminho para a universalização do seguro social, entrevendo-se uma espécie de securitização das atividades produtivas. No caso brasileiro, anote-se a consolidação dessa linha evolutiva no campo dos acidentes de trabalho, nas atividades do Estado, nas relações de consumo, no transporte aéreo (Lei $n^{\circ} 7.565 / 86$ ) nos acidentes nucleares (Lei ${ }^{\circ}$ 6453/77), a caracterizar a dualidade do modelo (entre a culpa e o risco). Diante disso, parece inteiramente injustificada a lição, ainda presente nos
} 
geral da atividade de risco abriria um flanco para abarcar uma infinidade de situações que, diante da codificação anterior, necessitariam do elemento subjetivo para a eclosão do dever de reparar o prejuízo. Entrementes, é imperioso reconhecer que há doutrinadores que entendem não ser possível alargar demasiadamente a interpretação da expressão "atividade normalmente desenvolvida pelo autor do dano implicar por sua natureza risco para os direitos de outrem" para abranger qualquer atividade humana, porque todas possuem um certo risco, devendo açambarcar apenas aquelas atividades realmente perigosas. ${ }^{342}$

Não obstante, vale a pena frisar que a culpa, ainda, possui um papel importante dentro na sistemática civilista, conquanto se extraia dela o aspecto didático para uma harmoniosa vida em sociedade. É dizer, os indivíduos em suas relações e atividades carregam a idéia, ainda que inconsciente, do dever de cuidado objetivo, fazendo com que as pessoas sejam mais cautelosas e previdentes. ${ }^{343}$

Além disso, a responsabilidade civil dos pais pelos atos dos filhos capazes apenas surgirá, nos moldes aqui defendidos, caso o autor material do ato danoso aja com culpa, fato este que demonstra a importância do elemento subjetivo para a eclosão do dever de indenizar.

manuais de direito civil, segundo a qual a responsabilidade civil, em regra, seria aquiliana ou subjetiva, sendo a responsabilidade objetiva excepcional, engendrada a aplicada pelo direito público". TEPEDINO, Gustavo. Temas de direito civil, cit., p. 183-184.

Neste mesmo sentido, Luiz Roldão de Freitas Gomes, leciona que: "Pode-se hoje dizer que, com a evolução da responsabilidade objetiva, na legislação sobre acidentes do trabalho, no seguro obrigatório de responsabilidade, na responsabilidade civil do Estado, no Código de Mineração, nos danos causados ao meio ambiente, no Código Brasileiro de aeronáutica, para as instituições financeiras e no Código de Defesa do Consumidor, que se fragmentou o sistema da responsabilidade civil em nosso Direito, centrada na culpa, como inscrita no Código Civil”. GOMES, Luiz Roldão de Freitas. op. cit., p. 20.

Cláudio Luiz Bueno de Godoy aduz que: "O art. 927, que inaugura o título destinado ao tratamento da responsabilidade civil, fonte do direito obrigacional, consagra, em seu texto, o que representa inovação do sistema: a coexistência genérica e, segundo se entende, não hierarquizada da regras baseadas na teoria da culpa e na teoria do risco". (grifos nossos) GODOY, Cláudio Luiz Bueno de. op. cit., p. 765; "De fato, com a cláusula geral de responsabilidade objetiva por atividades de risco contida no parágrafo único do art. 927 , o legislador de 2002 espancou definitivamente a idéia da prevalência da culpa no sistema brasileiro". SHREIBER, Anderson. op. cit., p. 23; "Creio que a responsabilidade civil objetiva há de prevalecer, mas a legislação não afastará totalmente a subjetiva. O Código Civil é exemplo dessa convivência, pois, enquanto o art. 186, a que faz remissão o caput do art. 927, refere-se à responsabilidade subjetiva, o parágrafo único deste artigo representa verdadeira cláusula geral de responsabilidade objetiva, a ser definida pelo juiz". CHINELATO, Silmara Juny de Abreu. op. cit., p. 597.

${ }^{342}$ SHREIBER, Anderson. op. cit., p. 23.

${ }^{343}$ De acordo com o escólio de Caio Mario: "Filosoficamente, a abolição total do conceito de culpa vai dar num resultado anti-social e amoral, dispensando a distinção entre o lícito e o ilícito, ou desatendendo à qualificação boa ou má da conduta, uma vez que o dever de reparar tanto corre para aquele que procede na conformidade da lei quanto para aquele outro que age ao seu arrepio.” PEREIRA, Caio Mário da Silva. Instituições de direito civil. Contratos. Declaração unilateral de vontade. Responsabilidade civil, cit., v. 3, p. 394. 
Sobreleva ressaltar, ainda, que, nas ações de regresso, o fenômeno da culpa, nas circunstâncias aqui explicitadas, continuará desempenhando um papel relevante para pacificar relações jurídicas surgidas com a prática de atos ilícitos. É mister reiterar, que a responsabilidade civil objetiva, prevista no Código Civil de 2002, não representou uma novidade no sistema, vez que antes de sua entrada em vigor o ordenamento jurídico já a previa em legislação especial, Lei $n^{\circ}$ 6938/81, em seu artigo 14, parágrafo único, ou posteriormente na própria $\mathrm{CF} / 88$, que trazia a responsabilidade civil do Estado, a responsabilidade por danos ambientais ou nucleares.

Nesse diapasão, vislumbrar-se-ia, na responsabilidade independentemente de culpa, a presença apenas da conduta, do dano e do nexo de causalidade, como elementos essenciais para o surgimento do dever de indenizar, de modo que não se cogitaria da intenção ou do modo de atuação do agente, tudo em virtude da consagração, pelo sistema, da teoria do risco. ${ }^{344}$

A teoria do risco comporta várias vertentes, podendo ser visualizado, no direito pátrio, a adoção de muitas delas que se alocam em locais diversos, dependendo do ramo jurídico que é objeto de análise. A doutrina, outrossim, diverge quanto às várias espécies de teoria do risco. ${ }^{345}$

Com efeito, fala-se hoje em teoria do risco integral, em que a obrigação de indenizar surge meramente do fato, sendo suficiente a existência do dano conectado a um fato; a teoria do risco proveito, fundamentado na idéia de que aquele que aufere um ganho deve suportar um incômodo - ubi emolumentum, ibi onus; teoria dos atos normais e anormais, mensurados pelo médio padrão da sociedade. Não obstante, a teoria perfilhada pelo Código Civil de 2002 foi a do risco criado, pela qual a obrigação de indenizar surge da atividade normalmente desenvolvida pelo sujeito que acaba criando riscos a direitos

\footnotetext{
${ }^{344}$ TEPEDINO, Gustavo. Temas de direito civil, cit., p. 175.

${ }^{345}$ Fernando Noronha, por exemplo, assinala que são três os riscos que fundamentam a responsabilidade objetiva, "todos relacionados com determinadas atividades: o risco de empresa, o risco administrativo e o risco perigo. Esses riscos podem ser sintetizados dizendo-se: que quem exerce profissionalmente uma atividade econômica, organizada para a produção ou circulação de bens ou serviços, deve arcar com todos os ônus resultantes de qualquer evento danoso inerente ao processo produtivo ou distributivo; que a pessoa jurídica pública responsável, na prossecução do bem comum, por uma certa atividade, deve assumir a obrigação de indenizar particulares que porventura venham a ser lesados, para que os danos sofridos por estes sejam redistribuídos pela coletividade beneficiada; que quem se beneficia com uma atividade potencialmente perigosa (para outras pessoas ou para o meio ambiente), deve arcar com eventuais conseqüências danosas". NORONHA, Fernando. op. cit., p. 37.
} 
alheios. Para essa teoria, pouco importa a vantagem ou proveito para a pessoa que desenvolve a atividade perigosa, ${ }^{346}$ o que é relevante é o seu potencial perigo a terceiros. ${ }^{347}$

A teoria do risco integral é utilizada por alguns administrativistas ${ }^{348}$ para fundamentar a responsabilidade civil do Estado, sendo que para outros doutrinadores ela não poderia ser aplicada, conquanto conduza à iniquidade social e ao abuso. Para Hely Lopes Meirelles a teoria do risco integral jamais teria sido acolhida entre nós, porquanto foi perfilhada por nosso sistema a teoria do risco administrativo. ${ }^{349}$ Para o citado autor, o Estado deve indenizar independentemente de culpa, sempre que o ato praticado pelo agente estatal cause prejuízo injusto ao administrado, não se perquirindo, como referido, o elemento subjetivo do funcionário do Estado ou qualquer falta do serviço público, bastando a comprovação da lesão e do nexo de causalidade.

\footnotetext{
${ }^{346}$ Claudio Luiz Bueno de Godoy, em sentido contrário, aduz que deve existir algum proveito para aquele que desenvolve a atividade com risco, não precisando ser esta vantagem necessariamente econômica. "O risco deve ser inerente à atividade e não resultar do específico comportamento do agente...São hipóteses em que, mesmo lícita e exercitada regular e normalmente, a atividade por si cria maior risco a terceiros, independentemente de quem a exerça". GODOY, Cláudio Luiz Bueno de. op. cit., p. 765-766.

${ }^{347}$ SILVA, Regina Beatriz Tavares da (Coord.). Novo Código Civil comentado. 6. ed. rev. e atual. São Paulo: Saraiva, 2008. p. 833; Alvino Lima, em sua obra já citada, alude que a primeira teoria da responsabilidade objetiva foi a do risco integral, considerada pelos defensores da responsabilidade subjetiva extremamente rigorosa, em razão de sua máxima preocupação com a reparação do dano mesmo que involuntário. Posteriormente, surgiram as teorias do ato anormal, de Ripert, que a adotou para regrar os problemas das relações de vizinhança em que a utilização da propriedade era feita de forma anormal e a teoria de Josserand, intitulada de risco-proveito. Na opinião do referido Professor, "a teoria objetiva, que funda a responsabilidade extra-contratual no risco criado pelas múltiplas atividades humanas, foi, sem dúvida, a que fixou as bases da nova concepção da responsabilidade sem culpa, passando do campo doutrinal para o direito positivo. O movimento iniciado por Saleilles, como vimos, encontrou na obra de Josserand o seu mais ardente e possante defensor, e a despeito das críticas que lhe foram dirigidas..., aquela teoria encontrou a consagração, não só em dispositivos do direito comum, mas também na legislação especial. Partindo da necessidade da segurança da vítima, que sofreu o dano, sem para ele concorrer, os seus defensores sustentam que "lês faiseurs d'actes", nas suas múltiplas atividades, são os criadores de riscos, na busca de proveitos individuais. Si destas atividades colhem os seus autores todos os proveitos ou pelo menos agem para consegui-los, é justo e racional que suportem os encargos, que carreguem com os ônus, que respondam pelos riscos disseminados - Ubi emolumentum, ibi onus. - Não é justo, nem racional, nem tampouco eqüitativo e humano que a vítima, que não colhe os proveitos da atividade criadora dos riscos e que para tais riscos não concorreu, suporte os azares da atividade alheia". LIMA, Alvino. Da culpa ao risco, cit., p. 91-93.

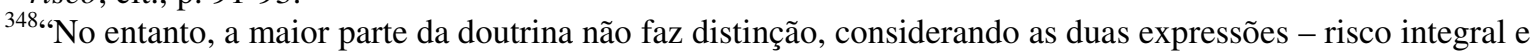
risco administrativo - como sinônimos ou falando em risco administrativo como correspondendo ao acidente administrativo. Mesmo os autores que falam em teoria do risco integral admitem as causas excludentes da responsabilidade". DI PIETRO, Maria Sylvia Zanella. Direito administrativo. 20. ed. São Paulo: Atlas, 2007. p. 600.

${ }^{349}$ Hely Lopes Meirelles, ao criticar o posicionamento de alguns autores acerca da adoção, por nosso sistema, da teoria do risco integral, afirma que: "Contestamos formalmente esse entender, que se desgarra da doutrina acolhida pelo nosso direito e se divorcia da jurisprudência que se formou acerca do citado dispositivo constitucional, consagrador da teoria objetiva, mas sob a modalidade do risco administrativo e não do risco integral”. MEIRELLES, Hely Lopes. op. cit., p. 586.
} 
Mais consentâneo com esta definição de risco integral, teoria que exige apenas o vínculo entre o fato e o dano para o surgimento do dever de indenizar, seria a hipótese de responsabilidade por acidentes nucleares e danos ambientais, ${ }^{350}$ em que inclusive o caso fortuito ou a força maior seriam incapazes de exonerar do dever de indenizar.

A doutrina trata, também, da teoria do risco profissional ou social, como sendo aquele que fundamentaria a seguridade social. A atividade laborativa, resultado do vínculo de emprego entre empregador e empregado, afasta a idéia de culpa, obrigando o patrão a ressarcir os danos ocasionados em seu serviçal por acidentes de trabalho em razão da disponibilidade do empregado para o trabalho. ${ }^{351}$

Fala-se, ainda, como acima citado, na teoria do risco proveito em que a periculosidade da atividade deve estar relacionada com o lucro buscado pelo responsável. $\mathrm{Ou}$ seja, aquele que retira vantagem ou proveito do fato que porventura venha a causar prejuízo a outrem é obrigado a indenizá-lo - ubi emolumentun, ibi onus. ${ }^{352}$

Todavia, os seus opositores passaram a questionar a real definição e contorno do vocábulo proveito, surgindo celeuma doutrinária quanto ao seu alcance. Vale dizer, essa vantagem a que deveria estar conectado o risco da atividade, seria necessariamente econômica ou independeria do fator financeiro $?^{353}$ No entanto, a essência dessa teoria estaria ligada aos proveitos individuais perquiridos pelo agente por meio de atividades criadoras de risco. 354

A despeito de todas essas teorias, aquela consagrada por nosso Código Civil de 2002 foi a teoria do risco criado. ${ }^{355}$ Já dizia Alvino Lima:

\footnotetext{
${ }^{350}$ De acordo com as lições de Teresa Ancona Lopes: "Esses dois casos são informados pela teoria do risco integral e são exceções à regra da teoria do risco da atividade, pois nesta há a atuação das causas excludentes da responsabilidade. Na teoria do risco integral, basta a ligação entre o fato e o dano para levar à responsabilização de seu causador. Apenas e tão-somente nesses casos a responsabilidade é automática.". LOPEZ, Teresa Ancona. Princípio da precaução e evolução da responsabilidade civil, cit., p. 149.

${ }^{351}$ ALONSO, Paulo Sergio Gomes. op. cit., p. 61.

${ }^{352}$ Id. Ibid., p. 63.

${ }^{353}$ Id. Ibid., p. 64.

${ }^{354}$ Alvino Lima, ao encerrar suas explanações acerca da teoria do risco proveito disserta que: "A questão da responsabilidade, que é mera questão de reparação de danos, de proteção do direito lesado, de equilíbrio social, deve, pois, ser resolvida atendendo somente àquele critério objetivo; quem guarda os benefícios que o acaso de sua atividade lhe proporciona, deve, inversamente, suportar os males decorrentes desta mesma atividade". LIMA, Alvino. Da culpa ao risco, cit., p. 93-94.

${ }^{355}$ “Certo, neste cenário, é apenas que as esforçadas tentativas de especificação da cláusula geral têm conduzido a equívocos mais ou menos evidentes. Parte da doutrina tem, por exemplo, sustentado afigurarse imprescindível, para a incidência do parágrafo único do art. 927, a constatação de proveitos econômicos
} 
"A teoria objetiva, que funda a responsabilidade extra-contratual no risco criado pelas múltiplas atividades humanas, foi, sem dúvida, a que fixou as bases da nova concepção da responsabilidade sem culpa, passando do campo doutrinal para o direito positivo". 356

Carlos Roberto Gonçalves aduz que o Código Civil de 2002, como se percebe, consagrou a teoria do risco de uma maneira mais avançada e radical que o Direito Italiano, ao adotar a teoria do exercício da atividade perigosa e o princípio da responsabilidade civil objetiva, nos casos expressos em lei, a par da manutenção da responsabilidade civil subjetiva, como regra geral, não permitindo que o agente causador do dano se exonere da responsabilidade de indenizar mediante a comprovação de que tomou todas as medidas necessárias e possíveis para impedir o dano. ${ }^{357}$

Essa teoria, de acordo com o supracitado autor, subsume-se à idéia de que a reparação origina-se do exercício de atividade perigosa. A atividade perigosa exercida pelo agente pode representar um risco pelo qual deve responsabilizar-se, assumindo, por conseguinte, a obrigação de tornar indene à esfera jurídica de outrem, desde que ocorra o prejuízo advindo desse fato. O sistema italiano abarca o exercício da atividade perigosa como fundamento da responsabilidade civil. Contudo, prevê a possibilidade da inversão do ônus da prova para a elisão da obrigação de indenizar, caso o agente demonstre que tomou todas as medidas aptas a evitar o dano. Disposições assemelhadas podem ser encontradas nos Códigos Civis espanhol, mexicano, libanês, português. ${ }^{358}$

Entretanto, preferimos utilizar a expressão atividade de risco, tal como referida no parágrafo único do artigo 927 do CC/2002, uma vez que este último vocábulo, de acordo com o escólio de Teresa Ancona Lopes, retrata uma situação fática diferente daquela

auferidos por quem desempenha atividade lesiva... Tal entendimento parece, no entanto, insustentável diante da própria redação do dispositivo, que, ao aludir apenas ao risco, sem cogitar do seu aproveitamento pelo responsável, sugere fortemente a adoção da teoria do risco-criado, e não do risco proveito". SHREIBER, Anderson. op. cit., p. 24.

${ }^{356}$ LIMA, Alvino. Da culpa ao risco, cit., p. 93.

${ }^{357}$ GONÇALVES, Carlos Roberto. Responsabilidade civil. 7. ed. São Paulo: Saraiva, 2002. p. 8. Neste sentido, é curial trazer os estudos de Alvino Lima que, ao analisar e relacionar os posicionamentos contrários à adoção da teoria do risco, inclui aquele defensor de seu atraso que afirma: "A teoria do risco é a estagnação da atividade individual, paralisando as iniciativas e arrastando o homem à inércia, visto como, diante da responsabilidade sem culpa, de nada valem a prudência, a conduta irreprovável, as precauções e cautelas, porquanto o agente deverá assumir a responsabilidade de todos os danos que possam resultar das suas ações lícitas e necessárias. As leis de acidentes de trabalho apenas regulam a reparação de uma parte do dano, não tendo adotado integralmente a teoria do risco". LIMA, Alvino. Da culpa ao risco, cit., p. 137-138.

${ }^{358}$ GONÇALVES, Carlos Roberto. Responsabilidade civil, cit.; neste mesmo sentido ver GODOY, Cláudio Luiz Bueno de. op. cit., p. 767. 
expressada pela palavra perigo. Sublinhe-se que, nas lições da citada autora, o risco é mais abstrato e representa "um perigo eventual mais ou menos previsível, diferentemente da álea (imprevisível) e do perigo (real)." ${ }^{, 359} \mathrm{O}$ risco traz uma idéia de incerteza.

Deveras, Adriano de Cupis, em comentários ao art. 2050 do Código Civil Italiano, assevera que o codificador optou por uma solução intermediária entre a responsabilidade subjetiva e a responsabilidade objetiva, conquanto tenha previsto hipótese de inversão do ônus da prova da culpa, ao impor a incumbência do autor do prejuízo de demonstrar, para afastar o seu dever de indenizar, que, apesar da ocorrência da lesão adotou todas as medidas idôneas para evitar o dano. ${ }^{360}$

Insta ressaltar, por oportuno, que essa corrente que entende tratar-se de intemediária a responsabilidade civil, prevista no art. 2050 do Código Civil Italiano, não é unânime, uma vez que há doutrinadores que advogam a idéia de que o mencionado artigo exigiria a prova do fato objetivo de que se adotaram medidas adequadas, de acordo com a técnica, para impedir a lesão. ${ }^{361}$

Apesar da codificação brasileira inspirar-se nos modelos da portuguesa e italiana ${ }^{362}$ foi ela mais arrojada ao implementar a responsabilidade objetiva em seu Código Civil, uma vez que não previu uma forma de ilidir o dever de indenizar, por meio da comprovação de que o causador do dano adotou todas as medidas necessárias para evitá-lo. ${ }^{363}$

\footnotetext{
${ }^{359}$ LOPEZ, Teresa Ancona. Princípio da precaução e evolução da responsabilidade civil, cit., p. 25.

${ }^{360}$ DE CUPIS, Adriano. Commentario del Codive Civile. A cura di Antonio Scialoja e Giuseppe Branca. Libro Quatro delle Obligazioni. Bolgna: Nicola Zanichelli Editore, 1964. p. 331. FERNÁNDEZ CRUZ, Gastón; LEÓN HILARIO, Leysser. op. cit., p. 28.

${ }^{361}$ FERNÁNDEZ CRUZ, Gastón; LEÓN HILARIO, Leysser. op. cit., p. 30.

${ }^{362} \mathrm{O}$ artigo 493, do Código Civil português, de 1966, dispõe: "Art. 493. [...] 2. Quem causar danos a outrem no exercício de uma actividade, perigosa por sua própria natureza ou pela natureza dos meios utilizados, é obrigado a repará-los, excepto se mostrar que empregou todas as providências exigidas pelas circunstâncias com o fim de os previnir". Neste mesmo sentido, preconiza o art. 2050 do Código Civil Italiano: "Chiunque cagione danno ad altri nello svolgimento di un' attività pericolosa, per sua natura o per la natura dei mezzi adoperati, è tenuto al risarcimento se non prova di avere adottato tutte le misure idonee a evitare il danno".

${ }^{363}$ SHREIBER, Anderson. op. cit., p. 22. Disserta, com propriedade, Claudio Luiz Bueno de Godoy ao mencionar que: "Por fim, anote-se que preceito semelhante àquele ora em comento se contém no art. 2050 do Código Civil italiano, entretanto com o acréscimo de que o perigo pode estar na natureza não da atividade, mas dos meios adotados para o seu exercício, o que aqui pode ser cogitável se esses meios forem os normais para o desempenho daquele mister. Mas, ao contrário do dispositivo peninsular, não admite o novo CC que o agente possa eximir-se de sua responsabilidade objetiva provando ter tomado todas as medidas idôneas a evitar o risco. Essa previsão, aliás, estava na redação original do anteprojeto do Código Civil, mas foi suprimida em sua tramitação". E arremata o autor: "De toda sorte, a conclusão, enfim, é que o sistema hoje dota a vítima, observados os respectivos requisitos, de mecanismos de responsabilização do agente independentemente da demonstração de sua culpa, cujo papel, como fonte irradiadora da obrigação reparatória, se substitui pela causalidade, todavia não de maneira absoluta - não se dota, como se disse
} 
Não obstante essas considerações acerca da atividade perigosa, entendemos que a lei condiciona a responsabilidade independentemente de culpa ao risco da atividade e, nesse sentido, imperioso se torna, em razão da própria abertura da referida cláusula geral trazer os princípios constitucionais para a sua adequada interpretação, conforme será feita uma análise melhor adiante.

Pensamos, inclusive, baseando-nos nos ensinamentos de Silvio Rodrigues, ${ }^{364}$ que a paternidade e a conseqüente assunção pelos pais do desenvolvimento da atividade denominada de poder familiar, traz em si um risco para os direitos de outrem que não pode ser ignorado pelo jurista.

Indubitavelmente, como referido alhures, a imprecisão semântica de algumas expressões contidas no debatido parágrafo único do art. 927, tais como atividades "normalmente desenvolvidas" que impliquem "risco para os direitos de outrem", pode gerar celeuma doutrinária e jurisprudencial quanto aos limites jurídicos dessas cláusulas gerais. $^{365}$

Contudo, em nossa opinião, é inegável que o exercício estendido do poder familiar, como ocorre no caso de filhos capazes, consiste em uma atividade plenamente lícita. Entretanto, traz em si riscos para interesses de outras pessoas.

Para Silmara Juny Chinelato, a palavra atividade tem um conteúdo certo, técnico e preciso, indicativo de organização, profissionalismo, habitualidade, noção confirmada pela expressão que se lhe segue: "normalmente desenvolvida". De se consignar que o art. 186 do atual Código Civil, aludido pelo caput do art. 927 do mesmo diploma legal, dispõe “ação ou omissão voluntária" que se refere a ato isolado, individual, não habitual. ${ }^{366}$

A teoria do risco criado preconiza que, se uma pessoa desenvolve uma atividade que traga em si o elemento risco (no sentido de perigo eventual), ainda que lícita, responderá pelos prejuízos causados a terceiros em virtude dessa atividade,

acima, a teoria do risco integral, de causalidade pura -, inclusive porque concorrentes excludentes, mesmo à míngua de uma regra geral que as contemplasse, como há no Código de Defesa do Consumidor (Lei $\mathrm{n}^{\circ}$ $8.078 / 90$, arts. 12 , parágrafo $3^{\circ}$, ou 14 , parágrafo $3^{\circ}$ ), mas, de qualquer maneira, sempre ressalvadas em hipóteses específicas, como as dos arts. 936 e seguintes, por exemplo, e a seguir examinadas." GODOY, Cláudio Luiz Bueno de. op. cit., p. 767.

364“A idéia de risco é a que mais se aproxima da realidade. Se o pai põe filhos no mundo, se o patrão se utiliza do empregado, ambos correm o risco de que da atividade daqueles surja dano para terceiro." RODRIGUES, Silvio. Direito civil: responsabilidade civil, cit., v. 4, p. 61.

${ }^{365}$ FERNÁNDEZ CRUZ, Gastón; LEÓN HILARIO, Leysser. op. cit., p. 27.

${ }^{366}$ CHINELATO, Silmara Juny de Abreu. op. cit., p. 593. 
independentemente da demonstração do elemento subjetivo. Ou seja, o ponto fulcral dessa teoria está no elemento perigo, inerente em muitas atividades que expõem em contínuo risco os sujeitos de direito.

Há autores que pretenderam restringir a aplicação da atividade de risco na exigência de que ela se expresse organizada sob a forma de empresa, ${ }^{367}$ interpretação que não encontrou fundamento no dispositivo em comento e apenas se refere à natureza da atividade que, "por sua natureza" causa risco para direitos de outras pessoas. É mister explicitar, ainda, que mencionada ilação vai de encontro com o próprio sistema desenvolvido pela codificação, porque já conta com dispositivo específico em relação à responsabilidade do empresário. ${ }^{368}$

Devemos considerar, também, que há inclusive aqueles que sustentam a inutilidade do parágrafo único do art. 927, pelo fato de reiterar o regramento estipulado no Código de Defesa do Consumidor em relação à responsabilidade pelo fornecimento de serviços. Porém, a despeito de, por vezes, haver uma coincidência de subsunção dos artigos do diploma consumerista e civilista a certas circunstâncias fáticas, não é possível asseverar que sempre ocorrerá essa adequação normativa. A norma consumerista exige certos requisitos que não são requeridos no Código Civil, de forma que o seu artigo 927 fundamenta-se na socialização dos riscos. ${ }^{369}$

A interpretação do art. 927, parágrafo único, do atual Código Civil, a nosso ver, deve utilizar o diálogo das fontes, na forma proposta por Erik Jayme, com o escopo de se socorrer de outros Códigos, tal como o Código de Defesa do Consumidor que tão bem incorporou a evolução do instituo da responsabilidade civil e que poderá, por conseguinte, fornecer os elementos necessários ao julgador e ao intérprete para a obtenção do conteúdo interpretativo adequado à cláusula geral prevista no dispositivo em comento. ${ }^{370}$

\footnotetext{
367، A prática de atos racionalmente ordenados e com habitualidade bem como a exposição a riscos de direitos de outrem são essenciais à identificação da atividade constitutiva da responsabilidade civil objetiva material, mas, de novo, não bastam. A atividade a que se refere a lei, na parte final do parágrafo único do art. 927 do CC, é a que viabiliza a socialização de custos. Não havendo específica previsão legal atribuindo responsabilidade objetiva, ninguém deve ser responsabilizado por ato lícito, se não tiver meio de socializar os custos de sua atividade... A imputação, em regra, de responsabilidade objetiva aos empresários é plenamente justificável. Encontram-se eles sempre numa posição econômica que lhes permite socializar, entre os seus consumidores os custos associados aos acidentes. " COELHO, Fábio Ulhoa. Curso de direito civil, cit., v. 2, p. 349-351.

${ }^{368}$ SHREIBER, Anderson. op. cit., p. 24.

${ }^{369}$ Id. Ibid., p. 24-25.

${ }^{370}$ CHINELATO, Silmara Juny de Abreu. op. cit., p. 594.
} 
É interessante explicitar que, em nosso sentir, a pertinente interpretação da cláusula geral, "atividade de risco", depende, também, da busca dos elementos constantes do artigo 932 do atual Código Civil, que trata da responsabilidade civil por fato de terceiro e que, como será explicado oportunamente, retrata uma série de circunstâncias da vida que expressam sujeição do autor material do dano ao civilmente responsável e muito se assemelham às situações de fato vivenciadas pela pessoa capaz que vive sob a dependência econômica de seus genitores.

Dessa forma, os juízes terão que desempenhar essa importante função de definir, sempre levando em consideração, em nossa opinião, a necessidade de se conferir uma maior proteção à vítima, os parâmetros da cláusula geral em debate, sendo relevante reconhecer, outrossim, que, inobstante pudesse representar maior segurança jurídica o fornecimento por parte do legislador de diretrizes e limites para a definição das atividades mencionadas na segunda parte do parágrafo único do art. 927 do atual Código Civil, caso o fizesse o codificador deveria fazer uma opção por um rol exemplificativo. ${ }^{371}$

Destarte, pode-se concluir que a responsabilidade civil, quanto ao direito brasileiro, passou e vem passando por modificações em sua estrutura que demonstram uma maior preocupação do sistema com a vítima, ${ }^{372}$ de acordo com o escólio de Alvino Lima, tornando, conseguintemente, menos árdua a obtenção de indenização, no caso de prejuízo perpetrado por outrem em sua esfera jurídica de interesse.

Vale dizer, a teoria subjetiva calcada na culpa, que em um determinado momento histórico representou uma revolução no instituto da responsabilidade civil, foi se tornando ineficaz para atender à principiologia constitucional de um Estado Democrático de Direito que tem como fundamento o mega-princípio da dignidade da pessoa humana. ${ }^{373}$

Por fim, inobstante todas essas considerações e discussões atinentes à responsabilidade objetiva calcada, na teoria do risco, impende destacar que o seu real

\footnotetext{
${ }^{371}$ Id., loc. cit. De acordo com a citada autora: "Já existem vários acórdãos dos diversos Tribunais que aplicam cumulativamente o parágrafo único em tela com dispositivos de leis especiais, como a Lei Ambiental (Lei 6.938/1981) e com a Constituição Federal (art. 37, § 6º, quanto a responsabilidade civil do Estado".

${ }^{372}$ LIMA, Alvino. Da culpa ao risco, cit.

373،Hoje, mais de um século depois da criação da teoria do risco em França, que remonta à última década do século XIX, a dignidade humana torna-se o princípio orientador de todo o ordenamento jurídico brasileiro e, por conseguinte, fortalece-se a objetivação da responsabilidade, como pretendiam Alvino Lima e Wilson Melo da Silva, entre outros civilistas nacionais. Daí a razão pela qual toda discussão sobre a responsabilidade subjetiva e responsabilidade objetiva deve ser firmada a partir desse princípio." LISBOA, Roberto Senise. Manual de direito civil: obrigações e responsabilidade civil, cit., v. 2, p. 448.
} 
fundamento também vem passando por questionamentos, por parte de alguns doutrinadores que vislumbram uma outra fundamentação para a sua estrutura.

Com efeito, para Anderson Schreiber, a responsabilidade objetiva, nos moldes em que se expressa por meio de nosso direito positivo, teria embasamento maior no resultado lesivo propriamente considerado e não no risco em si, porquanto em algumas hipóteses legislativamente previstas, afere-se a responsabilidade muito mais pela necessidade de se reparar a vítima do que pela criação do autor do dano de um risco. ${ }^{374}$

\begin{abstract}
"Em síntese: a criação ou majoração de um risco, como noção jurídica empregada por cláusulas gerais de responsabilização, continua sendo importante fator na aplicação da responsabilidade objetiva, mas perde seu papel de fundamento exclusivo do instituto na medida em que se vislumbram hipóteses de incidência desta espécie de responsabilidade em que não se pode, ou em que se pode apenas artificialmente, invocar o risco como fator de vinculação entre o dever de indenizar e o agente. Em tais situações, a responsabilidade objetiva parece revelar a sua verdadeira essência na contemporaneidade: não a de uma responsabilidade por risco, mas a de uma responsabilidade independente de culpa ou de qualquer outro fator de imputação subjetiva, inspirada pela necessidade de se garantir reparação pelos danos que, de acordo com a solidariedade social, não devem ser exclusivamente suportados pela vítima - uma proposição, portanto, essencialmente negativa". 375
\end{abstract}

Tudo a demonstrar que, desde que satisfeitos determinados requisitos sistemática e implicitamente previstos em lei, a responsabilidade dos pais pelos atos ilícitos praticados por seus filhos capazes é plenamente possível, uma vez que vai ao encontro dos princípios jurídicos implícitos e explícitos de nosso sistema jurídico.

\footnotetext{
374، Pense-se, por exemplo, na responsabilidade objetiva pelo effusum et deiectum, em que o dano pode ser verificado sem qualquer participação do ocupante do apartamento de onde cai o objeto que vem a atingir a vítima - objeto que, inclusive, poderia estar preso ao interior do apartamento ou seguro por um aparato qualquer, não representando, socialmente, um risco. Parece certo que, em hipóteses assim, a opção do legislador pela responsabilidade objetiva atende menos a uma - muitas vezes inexistente - contribuição do responsável para a criação ou incrementação do risco, e mais à necessidade de se assegurar à vítima o direito a alguma reparação, que restaria frustrada, na prática, houvesse ela de demonstrar a culpa do morador, já que o desprendimento do objeto pode ter bem se dado por razões muito próximas da mera fatalidade". SHREIBER, Anderson. op. cit., p. 29. Para Regis Fichtner Pereira: "A mudança de perspectiva quanto à investigação do dever de indenizar, da noção de culpa para a noção de dano injusto, pode ser um ponto de partida para a harmonização da doutrina da responsabilidade civil extracontratual com alguns princípios que embasam o sistema jurídico, tais como o princípio da solidariedade e o princípio do Estado Social, de sorte que a fixação do dever de indenizar passe por um exame valorativo dos interesses contrapostos". PEREIRA, Regis Fichtner. op. cit., p. 40.

${ }^{375}$ SHREIBER, Anderson. op. cit., p. 30.
} 


\subsection{A responsabilidade civil indireta e dos pais}

Como acima conceituado, o instituto da responsabilidade civil é a obrigação que incumbe a alguém de indenizar os danos causados na esfera jurídica de outrem, por ato próprio ou por ato de pessoa ou coisa a ela juridicamente vinculada, ou seja, de acordo com a definição de vários autores, a obrigação de indenizar surge, ainda, quando o ato lesivo é praticado por terceira pessoa dependente ${ }^{376}$ do responsável.

Com efeito, o surgimento da obrigação de reparar o prejuízo não apenas surgirá de ato próprio da pessoa, mas também pode advir de ato não praticado por ela, mas de pessoa ou coisa a ela ligada por uma relação jurídica ou uma relação de domínio. Nesse caso falase em responsabilidade indireta. ${ }^{377}$

De fato, se apenas os causadores de lesões fossem obrigados a reparar os danos, muitos prejuízos permaneceriam irressarcidos. Em razão disso, de há muito são admitidos pelos ordenamentos, em circunstâncias especificadas pela lei, que terceiros sejam responsáveis pela indenização, a despeito de não terem diretamente concorrido para o evento. $^{378}$

É curial esclarecer que a regra geral, como consabido, é a de responsabilidade civil direta, ou seja, por fato próprio. ${ }^{379}$ A responsabilidade civil pelo dano é, portanto, em princípio, somente atribuível àquele que lhe der causa, nos estritos termos do artigo 186 do Código Civil. É imperioso reconhecer, outrossim, que muitos doutrinadores ${ }^{380}$ advogam a

\footnotetext{
${ }^{376}$ DE RUGGIERO, Roberto. op. cit., v. 3, p. 599; SIMÃO, José Fernando. Responsabilidade civil pelo fato do animal: estudo comparativo dos Códigos Civis de 1916 e de 2002, cit., p. 344; RODRIGUES, Silvio. Direito civil: responsabilidade civil, cit., v. 4, p. 6. Neste sentido, é curial reconhecer que o Professor Silvio Rodrigues se utiliza da definição de Savatier para conceituar o instituto da responsabilidade civil.

377، A responsabilidade indireta tem caráter excepcional (Mazeaud e Mazeaud, Responsabilité Civile, vol. I, $\mathrm{n}^{\circ}$ 707) ou, como diz Sourdat, é uma derrogação da regra do art. 1.382 do Código Civil Francês, segundo o qual as conseqüências de uma culpa devem recair sobre seu autor. Se, pelo art. 1.384 a responsabilidade é imposta pelo fato de outrem, ocorre a derrogação daquele princípio (Traité General de la Responsabilité, vol. II, $\mathrm{n}^{\mathrm{o}}$ 750). Em qualquer dos casos previstos na lei, milita uma idéia que é comum a todos: o terceiro é responsável quando dispõe de uma autoridade de direito ou de fato sobre os outros. (De Page, Traité, vol.II, $\mathrm{n}^{\circ}$ 971, p. 920) PEREIRA, Caio Mário da Silva. Responsabilidade civil (de Acordo com a Constituição de 1988), cit., p. 85-86.

${ }^{378}$ VENOSA, Silvio de Salvo. Direito civil: responsabilidade civil. 8. ed., cit., v. 4, p. 69.

${ }^{379}$ DIREITO, Carlos Alberto Menezes; CAVALIERI FILHO, Sérgio. Comentários ao Código Civil. Da responsabilidade civil. Das preferências e privilégios creditórios. (arts. 927 a 965). Coordenador Sálvio de Figueiredo Teixeira. Rio de Janeiro: Forense, 2004. v. 13, p. 196.

${ }^{380}$ Id. Ibid., p. 198; VENOSA, Silvio de Salvo. Direito civil: responsabilidade civil. 8. ed., cit., v. 4, p. 71; sobre o tema, valiosa é a lição de Arnaldo Rizzardo, para quem: "Sobre o tema, valiosa é a lição de Arnaldo
} 
idéia de que, em realidade, a responsabilidade civil indireta não se caracterizaria pela assunção de um dever de uma pessoa indenizar ato danoso praticado por outrem, mas sim pela confluência de precedente causal imediato e mediato, em que alguém pratica um ato diretamente causador de dano e que o outro responsável se omite no dever de impedir essa lesão.

Em comentários ao art. 2.047, do Código Civil Italiano, Adriano de Cupis leciona, que, no caso de responsabilidade civil do incapaz, duas são as causas do dano. A primeira seria a incapacidade do incapaz de entender e querer e a outra é o comportamento negativo do responsável pela vigilância do incapaz, que não impediu que a lesão ocasionada diretamente pelo inimputável ocorresse. Insta destacar que o sistema italiano diferencia a responsabilidade dos genitores em duas situações: é dizer, se o filho não tem capacidade de entender e de querer, a responsabilidade civil dos pais terá como regime jurídico aquele estabelecido pelo art. 2.047 referido. Por outro lado, se o filho, apesar da menoridade, for capaz de entender e de querer, o artigo que regulará a obrigação de reparar dos pais é o art. 2048 do mesmo diploma legal. ${ }^{381}$

Regina Beatriz Tavares da Silva, em comentário ao artigo 932, do Código Civil de 2002, que trata da responsabilidade indireta, pronuncia que o ato ilícito pode ser perpetrado pela própria pessoa que responderá por ele, responsabilidade civil direta, ou o prejuízo pode ser ocasionado por terceira pessoa que esteja sob sua esfera de direitos, nesse caso a responsabilidade é denominada de indireta.

A referida responsabilidade indireta, de acordo com a autora, atende mais aos anseios de justiça, pois, por vezes, a responsabilidade civil direta é incompleta para atender ao escopo primordial do instituto debatido. Outros doutrinadores enfatizam a necessidade de se conformar os novos paradigmas da responsabilidade civil e a conseqüente

\footnotetext{
Rizzardo, para quem: "De certo modo, pois, não está fora de propósito concluir que a causa mediata do dano é o responsável, enquanto a causa imediata está na ação ou omissão do autor material do dano. Todavia, a causa eficiente, e por isso a imputação da responsabilidade está no que tem a guarda ou a vigilância. Porque não exercido o dever suficiente e controle é que aconteceu o dano. A infração do dever de vigilância, ou a falha no encargo de controle, enseja a obrigação de reparar as consequiências" (in RIZZARDO, Arnaldo. Responsabilidade civil. 3. ed. Rio de Janeiro: Forense, 2007. p. 107).

${ }^{381}$ DE CUPIS, Adriano. op. cit., p. 315.
} 
prevalência dos interesses da vítima, com a busca, no momento da reparação do dano, pelo economicamente mais forte para tornar indene à esfera jurídica de direitos do lesado. ${ }^{382}$

É mister reconhecer que, em sua opinião, não se responsabiliza alguém aleatoriamente por fato praticado por outrem, deve-se, necessariamente, haver um vínculo jurídico entre o causador do dano e aquele que responderá patrimonialmente por ele. Vale a pena ressaltar que a responsabilidade civil indireta abarca também os danos ocasionados por coisas ou animais ligados ao imputado. Do exposto, conclui-se, por conseguinte, que há responsabilidade civil indireta quando alguém é chamado a responder por dano ocasionado por outrem, por coisa ou animal a ele vinculado. ${ }^{383}$

"A responsabilidade por fato de outrem é, como recordam Mazeaud et Mazeuad, idéia muito antiga, ligada a uma época em que era acentuadamente forte a consciência de grupo, que absorvia o indivíduo. A obrigação de pagar o Welgerd, ou composição dos germanos, pesava solidariamente sobre a família. Ainda na idade média, podem ser identificados traços dessa responsabilidade de grupo, que se foi desvanecendo até perder-se de todo, com o enfraquecimento da organização familiar. Hoje, funda-se especialmente no dever de vigilância imputável à pessoa que se declara responsável". 384

Não seria exagero afirmar que, modernamente, a família possui uma estrutura fechada de grupo, fenômeno denominado de nuclearização, tornando os indivíduos que a compõem fortemente unidos e dependentes financeiramente daqueles que trabalham e têm patrimônio suficiente para sustentar as necessidades dos que, apenas tardiamente, vão ser inseridos no mercado de trabalho.

O atual Código Civil, mais avançado que o anterior e consentâneo com a contemporânea orientação jurisprudencial, traçada pelo verbete da súmula 341 do Supremo Tribunal Federal, estabelece que os pais, tutores e curadores, os empregadores e comitentes responderão pelos atos dos filhos, pupilos e empregados ou prepostos, "ainda que não haja culpa de sua parte", de acordo com o exposto nos artigos 932 e 933 do citado diploma legal. Isso corresponde à adoção pelo atual estatuto civil, por expressa disposição legal, da responsabilidade civil objetiva.

\footnotetext{
${ }^{382}$ VENOSA, Silvio de Salvo. Direito civil: responsabilidade civil. 8. ed., cit., v. 4, p. 73; RIZZARDO, Arnaldo. Responsabilidade civil, cit., p. 110; RODRIGUES, Silvio. Direito civil: responsabilidade civil, cit., v. 4, p. 60.

${ }^{383}$ SILVA, Regina Beatriz Tavares da (Coord.). op. cit., p. 896.

${ }^{384}$ DIAS, José de Aguiar. Da responsabilidade civil, cit., v. 2, p. 509.
} 
Todavia, adverte Carlos Roberto Gonçalves: é ônus do ofendido comprovar a culpa do incapaz, dos hóspedes e educandos. A obrigatoriedade de prova do elemento subjetivo destes se impõe como antecedente inarredável à deflagração do dever de reparar dos sujeitos referidos no art. 932 do atual Código Civil. ${ }^{385}$

Disso decorre que, se o filho menor, ou preposto, agiu em condições em que não se podia atribuir-lhe nenhuma culpa, caso fosse imputável, os responsáveis nada terão a reparar, evidentemente. ${ }^{386}$

Essa responsabilidade por fato de outrem, ${ }^{387}$ por representar exceção, poderia levar o intérprete a concluir que o seu rol seria taxativo, ${ }^{388}$ não permitindo, por conseguinte, de acordo com essa pretensa linha principiológica, que o aplicador do Direito analisasse as circunstâncias fáticas e, por analogia, aplicasse a mesma resposta jurídica a situações semelhantes. Contudo, e, felizmente, há doutrina ${ }^{389}$ e decisão de nosso STJ $^{390}$ que reconhece a pertinência da analogia, possibilitando que o hermeneuta retire a essência das hipóteses elencadas nos dispositivos que tratam da responsabilidade civil indireta e por fato da coisa para aplicar a casos análogos.

A interpretação analógica fica evidente a partir da análise dos julgamentos de nossos tribunais, que passaram a aplicar o dispositivo previsto no art. 1.521, III, do

\footnotetext{
${ }^{385}$ GONÇALVES, Carlos Roberto. Comentários ao Código Civil: parte especial: do direito das obrigações. São Paulo: Saraiva, 2003. v. 11, p. 425. Neste diapasão, afirma com propriedade Silvio Venosa que: "É necessário que o agente direto tenha agido com culpa ou, no caso de incapazes, que tenha ocorrido uma conduta contrária ao Direito, porque não se fala estritamente em culpa destes. Se o inimputável, menor ou outro incapaz, agiu de acordo com o Direito, em conduta que se fosse capaz não seria culposa, não há o que indenizar". VENOSA, Silvio de Salvo. Direito civil: responsabilidade civil. 8. ed., cit., v. 4, p. 72.

${ }^{386}$ DIREITO, Carlos Alberto Menezes; CAVALIERI FILHO, Sérgio. op. cit., p. 201.

${ }^{387}$ Esta expressão, responsabilidade civil por fato de outrem, é importada da doutrina francesa e criticada por alguns doutrinadores que entendem que, na realidade, a responsabilidade não é por fato de outrem, mas por conduta omissiva de quem teria o dever de guarda, vigilância, fiscalização e controle, não se desincumbindo bem deste ônus, razão pela qual ocorreu o dano na esfera jurídica alheia. Ainda nesta linha de pensamento e a guisa de conclusão, a referida lesão teria, então, duas causas, quais sejam, a causa imediata que seria o comportamento do autor material do dano que diretamente causa o prejuízo e a causa mediata, consubstanciada na conduta omissiva do civilmente responsável. RIZZARDO, Arnaldo. Responsabilidade civil, cit., p. 107 e DIREITO, Carlos Alberto Menezes; CAVALIERI FILHO, Sérgio. op. cit., p. 197.

${ }^{388}$ Alguns doutrinadores, de fato, entendem que o rol que era previsto no artigo 1.521 do Código Civil de 1916, correspondente ao atual art. 932, expressava uma enumeração limitativa e não enunciativa ou $a d$ exemplum. KARAM, Munir. op. cit., v. 65, p. 401.

${ }^{389}$ DIAS, José de Aguiar. Da responsabilidade civil. Rio de Janeiro: Renovar, 2006. p. 747-748.

${ }^{390}$ “Civil e Processual Civil. Responsabilidade dos pais e da avó em face de ato ilícito praticado por menor. Separação dos pais. Poder familiar exercido por ambos os pais. Dever de vigilância da avó. Reexame de fatos. Incidência da súmula 7/STJ. Dissídio jurisprudencial comprovado. Recurso Especial no 1.074.937 MA (2008/0159400-7).
} 
CC/1916, atual art. 932, aos casos de empréstimos de carros, para responsabilizar o proprietário do automóvel cedido por contrato de comodato, em caso de danos aos direitos de outrem ocasionados pelo motorista-comodatário.

Assim, passou-se a reconhecer, nessas circunstâncias, que o proprietário era o preponente e o comodatário era o preposto, possibilitando a aplicação da regra contida no dispositivo supracitado. ${ }^{391}$

Vale dizer, não é sempre que emerge translúcida a idéia de preposto. Preposto é aquele que exerce alguma atividade ou age de acordo com ordens de outra pessoa, ainda que eventualmente. Trata-se de uma ligação mais sutil do que aquela que liga empregador e empregado. Contudo, a interpretação de nossos tribunais, como será melhor demonstrado, na tendência de permitir sempre a indenização, tem alargado muito a definição de preposição. Essa abertura interpretativa demonstra o poder de nossa jurisprudência que, nas lições de Silvio Venosa, é a voz do Direito. ${ }^{392}$

A ocorrência do dano, sem a devida reparação, causa sensação de injustiça para a toda sociedade, vez que, desde os primórdios, o homem sempre buscou uma resposta para um prejuízo ocasionada na sua esfera jurídica de direitos.

Nessas condições, pode-se visualizar o disposto no art. 932, do Código Civil de 2002, que traz em rol exemplificativo para alguns doutrinadores, ${ }^{393}$ os casos em que haverá responsabilidade indireta, preconizando que "são também responsáveis pela reparação civil" as pessoas que indica nos incisos. É curial esclarecer que o referido artigo corresponde ao art. 1.521 do CC/1916 com algumas modificações.

Passadas essas observações introdutórias acerca da responsabilidade civil indireta, analisaremos com mais profundidade os casos previstos no artigo 932 do atual Código Civil que permitirão fundamentar a idéia da responsabilidade civil dos pais pelos atos ilícitos de seus filhos capazes.

\footnotetext{
391، OO sentido de preposição não se limita apenas àquele que presta atividades em favor de outrem, numa relação de subordinação, ou por conta de terceiro. Estendeu-se o conceito, abrangendo as pessoas que permitem o uso de bens por outros. Se alguém usa um veículo de um conhecido, ou amigo, ou parente, existe a autorização para tanto; mais precisamente, para a execução da atividade de dirigir ou manobrar em nome do proprietário. Retira-se, daí, a relação de preposição, o que leva a admitir a responsabilidade do proprietário pelos danos causados durante o período de empréstimo". RIZZARDO, Arnaldo. Responsabilidade civil, cit., p. 119. Neste sentido, Recursos Especiais n ${ }^{\circ}$ s 145.358-MG e 125.023-MG da $4^{\text {a }}$ e $3^{\text {a }}$ Turmas do STJ.

${ }^{392}$ VENOSA, Silvio de Salvo. Direito civil: responsabilidade civil. 8. ed., cit., v. 4, p. 89.

${ }^{393}$ DIREITO, Carlos Alberto Menezes; CAVALIERI FILHO, Sérgio. op. cit., p. 202-203.
} 
O inciso I, do supracitado artigo, trata da responsabilidade civil dos pais pelos atos dos filhos menores que estiverem sob sua autoridade e sua companhia. Faz-se mister explicitar que a perfilhada responsabilidade civil por fato de outrem, como será detalhado, passou por uma evolução, perante o nosso sistema jurídico, a partir do Código Civil de 1916, partindo da necessidade da comprovação da culpa dos pais por parte do lesado, para o reconhecimento da culpa presumida, desembarcando, ao final, para a adoção expressa, por nosso sistema jurídico, da citada teoria do risco e a consequente responsabilidade objetiva dos pais.

A referida evolução teve participação fundamental da jurisprudência brasileira, ao interpretar os artigos 1.521 e 1.523, ambos do CC/16, dando um sentido a eles bem diferente da vontade do legislador que ainda estava muito apegado à noção de culpa para a reparação do prejuízo.

Com efeito, em um primeiro momento, por intermédio de uma análise textual do artigo 1.521, acima referido, o Código Bevilaqua demonstrava ter acolhido a teoria objetiva de uma responsabilidade civil sem culpa, ao sugerir, por exemplo, que o pai respondesse sempre pelo dano causado pelo filho menor. Da mesma forma, encontravamse as situações do tutor, pelos atos do tutelado, assim como do preponente pelos atos do preposto.

No entanto, o mesmo Codex, logo em seu artigo 1.523, exigia a prova produzida, por parte da vítima, da culpa do pai para responsabilizá-lo. ${ }^{394}$ Indubitavelmente, nas palavras de Alvino Lima,

"o legislador pátrio não seguiu a melhor doutrina, impossibilitando, na maioria dos casos, a reparação dos danos causados por atos de prepostos e outros, pois deveria ter consagrado a presunção juris et de jure da culpa

\footnotetext{
394“'O legislador fixou no art. 1.521 a responsabilidade dos pais, dos tutores, curadores, patrões, amos ou comitentes e outros, pelos atos respectivamente, de seus filhos, tutelados, curatelados e prepostos. Si aí ficasse o legislador, teríamos duas consequiências jurídicas: - $1^{\mathrm{a}}$ ) - que estas pessoas ali enumeradas seriam responsáveis, exclusivamente, pelo fato de outrem; $2^{a}$ ) - que uma vez provado este fato de outrem surgiria a responsabilidade. Estaríamos, assim, em face da responsabilidade ex lege, sem necessidade da culpa. Não era este, entretanto o sistema que o legislador adotara, regulando a chamada responsabilidade indireta e complexa. Teria o legislador pátrio ido além do sistema da presunção juiris et de jure adotado pela jurisprudência francesa, como vimos. A responsabilidade das pessoas enumeradas no art. $1.521 \mathrm{~ns}$. I a IV resulta da culpa própria, embora o dano seja consequiência de ato material de terceiro; mas este simples ato material não basta para criar a responsabilidade daquelas referidas pessoas. $\mathrm{O}$ art. 1.523 veio completar o art. 1.521, para que o mesmo não pudesse ser interpretado como derrogativo do princípio genérico da necessidade da culpa, consagrado no art. 159 do Cód. Civil. Só no caso de culpa provada das pessoas enumeradas no art. 1.523 ns. I a IV surgirá a responsabilidade pelos atos de terceiros ali enumerados". LIMA, Alvino. Da culpa ao risco, cit., p. 184.
} 
adotada pela jurisprudência francesa ou a presunção juris tantum, nos termos do art. 831 do Código civil alemão". ${ }^{395}$

Deveras, tal solução ia de encontro com o preconizado pela legislação francesa, que no artigo 1.384 do Código Napoleônico presumia a culpa do pai, tutor, patrão, pelos atos dos filhos, tutelados e empregados, sendo-lhes assegurado o direito de fazer prova da impossibilidade de impedir o fato gerador do dano, com exceção da responsabilidade do patrão que era presumida absolutamente. Ou seja, à vitima era concedida uma posição processual mais vantajosa, vez que não necessitava provar a culpa das pessoas acima elencadas.

De acordo com as lições de Silvio Rodrigues, o legislador brasileiro era conhecedor do sistema francês. O art. 1.384, do Código Civil francês, na sua forma original de 1804, presumia, em sua primeira alínea e de maneira peremptória, que o pai, o patrão, o preponente, o preceptor, o artesão eram responsáveis pelos prejuízos causados pelo filho menor, pelo empregado, pelo preposto, pelo discípulo e pelo aprendiz. Na última alínea, o artigo em debate determinava que o pai, a mãe, os preceptores e artesãos poderiam elidir a referida responsabilidade se demonstrassem a impossibilidade de impedir o fato danoso. ${ }^{396}$

Não obstante, o diploma francês silencia a respeito da possibilidade do patrão e do preponente ilidirem, por meio de prova em contrário, suas responsabilidades, o que resulta na impossibilidade de demonstrar a isenção de culpa. ${ }^{397}$

O legislador brasileiro também conhecia o sistema alemão que, igualmente, trabalhava com presunção relativa de culpa por parte do preponente, em caso de dano causado pelo preposto. Nessa situação, o preponente, para se eximir da responsabilidade, deveria provar que observou todos os cuidados requeridos ou que o dano teria ocorrido, ainda que todas as precauções tivessem sido tomadas. ${ }^{398}$

No entanto, o legislador brasileiro perfilhou uma corrente mais conservadora em que se exigia de forma peremptória, com ônus para a vítima, a prova da culpa in vigilando

\footnotetext{
${ }^{395}$ LIMA, Alvino. Da culpa ao risco, cit., p. 186-187.

${ }^{396}$ RODRIGUES, Silvio. Direito civil: responsabilidade civil, cit., v. 4, p. 56.

${ }^{397}$ Id. Ibid.

${ }^{398}$ Id. Ibid.
} 
por parte do pai, ou da culpa in eligendo do patrão, para que eles pudessem ser responsabilizados pelos atos do filho ou do preposto, respectivamente.

Ocorre que, como já referido, o ônus da prova ficava a cargo da vítima, o que tornava essa tarefa extremamente difícil de ser desempenhada com êxito.

Dessa maneira, diante de uma situação retrógrada e extremamente difícil prevista pelo artigo 1.523 do Código Civil de 1916, ou seja, do ofendido ter que provar a culpa do pai ou do preponente para obter a indenização, dois caminhos poderiam ser traçados pelo juiz ou legislador.

O primeiro seria estabelecer uma presunção de culpa por parte de ambos, facilitando e viabilizando a reparação do dano, vez que ocorreria, nesse caso, uma inversão do ônus da prova. A segunda alternativa, mais radical, consistiria na imposição, nos casos relatados, do dever de indenizar sem qualquer cogitação da culpa.

A solução preconizada pelo ordenamento jurídico brasileiro foi menos severa, estabelecendo uma presunção de culpa dos pais, por meio de legislação posterior de 1927 , qual seja o Código de Menores, que alterou o preceito do artigo 1.523 do Código Civil de 1916, afirmando que haveria responsabilidade dos pais independentemente de seus filhos estarem em seu poder e em sua companhia, sem que houvesse, ainda, a necessidade de prova de culpa dos mesmos.

Vale explicitar que, a partir da entrada em vigor do Código de Menores, instituído pelo Decreto n. $17.943-\mathrm{A}^{399}$, de 12 de outubro de 1927 , cujos arts. $68, \S 4^{\text {o }}$, e 74 alteraram o disposto no art. 1.523, ocorreu a presunção relativa de culpa por parte dos genitores transferindo-lhes o dever de provar que o ato danoso ocorrera sem culpa da parte deles.

É imperioso reconhecer que, como acima foi referido, diversamente da atual disposição dessa forma de responsabilidade civil indireta, no art. $68, \S 4^{\circ}$, do Código de Menores de 1927, não havia exigência de estar o menor na companhia e sob o poder

\footnotetext{
${ }^{399}$ Era esta a redação do art. $68, \S 4^{\circ}$, do Decreto n. 17.943-A, de 12/10/1927: "§ $4^{\circ}$ São responsaveis, pela reparação civil do damno causado pelo menor os paes ou a pessoa a quem incumba legalmente a sua vigilancia, salvo si provarem que não houve da sua parte culpa ou negligencia. (Cod. Civ., arts. 1.521e 1.623.)". O art. 74 do referido Decreto, por sua vez, trazia a seguinte redação: "São responsaveis pela reparação civil do damno causado pelo menor, os paes ou a pessoa a quem incumbia legalmente a sua vigilancia, salvo si provarem que não houve da sua parte culpa ou negligencia. (Cod. Civ., arts. $1.521 \mathrm{e}$ 1.523.)".
} 
paterno para que fossem os genitores responsabilizados pelos atos danosos que seus filhos, porventura, praticassem.

Entretanto, a posterior legislação, também denominada Código de Menores, instituída pela Lei n. 6.697, de 10 de outubro de1979, curiosamente não cuidou do assunto, responsabilidade civil dos pais, e revogou, em seu art. 123, o Decreto n. 17.943-A/1927, deixando um vácuo legislativo quanto à necessidade ou não de prova de culpa dos pais.

Com efeito, para haver o fenômeno jurídico chamado repristinação, a lei posterior deve expressamente dar vigência à lei revogada, de acordo com o art. $2^{\circ}, \S 3^{\circ}$ da Lei de Introdução ao Código Civil (Decreto-Lei n. 4.657/42), fato este não ocorrido na hipótese aqui aventada. ${ }^{400}$

Diante do impasse interpretativo pergunta-se: antes da entrada em vigor do atual Código Civil qual regra deveria ser aplicada? Sílvio Rodrigues responde:
"Na realidade, pela redação do art. 1.523 do Código Civil de 1916 e com a posterior revogação do Código de Menores, o único texto a reger a responsabilidade dos pais por atos dos seus filhos é a regra do artigo 1.521 daquele Código, que dispunha: 'Art. 1.521. São também responsáveis pela reparação civil: I - os pais, pelos filhos menores que estiverem sob o seu poder e em sua companhia". 401

Assim, a regra que passou a vigorar, mesmo antes da entrada em vigor do atual Código Civil, era de que a responsabilidade dos pais seria objetiva, desde que os filhos estivessem sob seu poder e companhia. ${ }^{402}$

Impende considerar que a Lei n. 8.096/90, conhecida como Estatuto da Criança e do Adolescente, por intermédio do seu art. 267, revogou integralmente a Código de Menores de 1979, deixando, como já houvera feito a revogada codificação menorista, de tratar do tema relativo à responsabilidade civil dos pais.

O estudo do artigo 932, do atual Código Civil, ajudará a fundamentar a idéia sobre a responsabilidade civil dos pais pelos atos ilícitos de seus filhos capazes, desde que dependentes economicamente, já que com exceção do último inciso, todos os outros incisos do

\footnotetext{
${ }^{400}$ É este o teor do $\S 3^{\circ}$ do art. $2^{\circ}$, da LICC: "Salvo disposição em contrário, a lei revogada não se restaura por ter a lei revogadora perdido a vigência”.

${ }^{401}$ RODRIGUES, Silvio. Direito civil: responsabilidade civil. 19. ed. São Paulo. Saraiva, 2002. v. 4, p. 69.

${ }^{402}$ Id., loc. cit.
} 
dispositivo, em comento, trazem a previsão de circunstâncias fáticas que se assemelham àquelas vivenciadas por genitores de filhos capazes e financeiramente dependentes.

Dessa forma, como resultado de toda essa evolução, chegou-se expressamente à responsabilidade civil objetiva dos pais, de acordo com o atual Código Civil, com fundamento na teoria do risco, para alguns, ou supedaneada no dever objetivo de guarda e vigilância, para outros, ${ }^{403}$ pelos atos dos filhos menores que estiverem sob sua autoridade e companhia. Entretanto, é apropriado esclarecer que, em nossa opinião, a responsabilidade dos pais desprovida do elemento subjetivo de outrora tem fundamento na lei, de acordo com os artigos 927, § único, primeira parte e 932, I, ambos do atual Código Civil.

Dessa forma, são pressupostos para a deflagração do dever dos pais de indenizarem: (I) a menoridade do filho, (II) estar sob autoridade dos pais e (III) em sua companhia.

Nessa circunstância, é indiscutível a dependência, ainda que estipulada em lei, moral e material do filho em relação a seus pais. Assim, visando assegurar os interesses da pretensa vítima ${ }^{404}$ de um ato praticado por um indivíduo, nas condições acima relatadas, a lei estabelece a responsabilidade objetiva, ${ }^{405}$ elidindo, por conseguinte, qualquer possibilidade de discussão acerca da culpa in vigilando. ${ }^{406}$

\footnotetext{
${ }^{403 ،}$ "Há quem sustente que a responsabilidade dos pais em relação aos filhos menores, e a dos tutores e curadores em relação aos pupilos e curatelados, estaria fundada na teoria do risco. Os que assim entendem afirmam que se o pai põe filhos no mundo corre o risco de que, da atividade deles, surja dano para terceiro. A levar a teoria do risco a tal extremo, tudo passará a tê-la por fundamento, até o próprio nascimento. Parece-nos exagero falar em risco de ter um filho, risco de ser pai e assim por diante. Na tutela e na curatela, a impropriedade é ainda maior ao se falar em risco, porque representam um ônus para quem as exerce, verdadeiro munus publicum. O fundamento dessa responsabilidade é realmente outro. É o dever objetivo de guarda e vigilância legalmente imposto aos pais, tutores e curadores. Depreende-se isso do próprio texto legal, da expressão "estiverem sob sua autoridade e em sua companhia". Esse dever de guarda e vigilância é exigível daquele que tem autoridade sobre outrem e enquanto o tiver em sua companhia". DIREITO, Carlos Alberto Menezes; CAVALIERI FILHO, Sérgio. op. cit., p. 200-201.

${ }^{404}$ RODRIGUES, Silvio. Direito civil. 19. ed., cit., v. 4, p. 64.

${ }^{405}$ “Todos os atos lesivos que forem praticados pelos filhos se incluem na responsabilidade dos pais, que, naturalmente, oferecem mais condições econômicas de suportar a indenização". RIZZARDO, Arnaldo. Responsabilidade civil, cit., 2007, p. 112. Esta responsabilidade civil objetiva dos pais é defendida, na Argentina, por Jorge Mosset Iturraspe que, ao relacionar as vantagens de sua adoção, afirma que ela inclusive permite uma menor ingerência do Estado na intimidade e privacidade da família, porquanto a responsabilidade subjetiva, ao exigir a prova da culpa, impõe uma investigação maior do juiz na vida privada dos núcleos familiares com o objetivo de aferir se a conduta dos pais com relação aos filhos pode ter sido a causa do evento danoso ocasionado por ele. ITURRASPE, Jorge Mosset. El porqué de una responsabilidad paterna que margina la culpa. In: MOSSET ITURRASPE, Jorge; D'ANTONIO, Daniel Hugo; NOVELLINO, Norberto José. Responsabilidad de los padres, tutores y guardadores. cit., p. 115.

${ }^{406} \mathrm{É}$ curial esclarecer que Arnaldo Rizzardo critica essa postura legislativa de incucar aos pais a responsabilidade civil pelos atos dos filhos menores objetivamente. São suas as seguintes palavras: "Vão longe os tempos em que os filhos, na sua grande maioria eram submissos e atenciosos, solícitos e obedientes. Por fruto da evolução dos costumes, da sociedade liberalizada, do precoce amadurecimento, da
} 
A regra, diante do progresso de nosso ordenamento, é: os pais apenas respondam pelos atos lesivos dos seus filhos menores, ${ }^{407}$ não tendo responsabilidade por condutas danosas que sejam perpetradas por filhos absolutamente capazes, ainda que vivam sob a dependência econômica de seus genitores.

No que tange ao instituto da emancipação, previsto no art. $5^{\circ}$ do atual Código Civil, sobreleva ressaltar que o referido fenômeno jurídico tem o condão de fazer cessar a responsabilidade civil dos genitores, desde que não se trate de emancipação voluntária, ${ }^{408}$ ou seja, aquela resultante de um ato de vontade dos pais, exteriorizada por meio de escritura pública, independentemente de homologação judicial. ${ }^{409}$

Para nós, a emancipação voluntária teria o condão de afastar a responsabilidade dos pais pelos atos ilícitos praticados pelos filhos emancipados, desde que estes últimos já possuam independência econômica, embora que não provenha, necessariamente, de relação de emprego ou de estabelecimento empresarial. Vale dizer, o menor poderia se beneficiar de uma herança com potencialidade patrimonial suficiente para atribuir-lhe independência financeira e, posteriormente, ser emancipado pelos pais. Nesse último caso deveria ser considerada elidida qualquer responsabilidade dos pais pelos atos ilícitos de seu filho.

aceleração na propagação dos vícios, das influências negativas, os pais perdem completamente o poder de vigilância ou guarda, não porque desatentos, omissos, ausentes. Simplesmente não conseguem manter o controle, e sequer os ampara a lei na dominação pela força, pelo confinamento, e nem os poderes públicos assumem o papel dos pais no controle e na formação moral. De sorte que avançou demais a lei, ao impor a responsabilidade objetiva em tamanha extensão. Mesmo assim, desponta uma saída de tão imprevidente responsabilização inculcada aos pais. Ressalvou-se que são eles responsáveis enquanto os filhos estiverem sob sua autoridade e companhia". RIZZARDO, Arnaldo. Responsabilidade civil, cit., p. 113.

${ }^{407}$ A responsabilidade civil dos pais abarca, por óbvio, os filhos adotivos, sendo relevante esclarecer que a simples guarda, deferida nos termos do ECA, transfere também ao guardião o dever de vigilância. VENOSA, Silvio de Salvo. Direito civil: responsabilidade civil. 8. ed., cit., v. 4, p. 81. O Código Civil cubano, em seu art. 90.1 dispõe que: "Los padres o tutores son responsables de los daños y perjuicios causados por los menores de edad o incapacitados que estén bajo su guarad y custodia".

${ }^{408}$ O STF já decidiu que a emancipação do menor não afasta a responsabilidade dos pais (RTJ 62/108). Neste diapasão: "Responsabilidade civil - Colisão de veículos - Motorista menor emancipado -Irrelevância - Pai co-responsável - Ação procedente. $\mathrm{O}$ fato de o motorista culpado ser menor emancipado não afasta a responsabilidade do pai, a quem pertence o veículo causador do dano". (RT 494/92).

${ }^{409}$ "Na doutrina existem, porém, manifestações frontalmente contrárias a esse entendimento. A nosso ver, como aponta Carlos Roberto Gonçalves (1994:103) desaparece a responsabilidade dos pais quando a emancipação decorre de outras causas relacionadas no art. $5^{\circ}$, parágrafo único, que não da iniciativa do pai ou tutor, como o casamento, por exemplo". VENOSA, Silvio de Salvo. Direito civil: responsabilidade civil. 8. ed., cit., v. 4, p. 79. Arnaldo Rizzardo entende que qualquer espécie de emancipação teria o condão de ocasionar a ruptura do dever de responsabilidade civil dos pais. RIZZARDO, Arnaldo. Responsabilidade civil, cit., p. 114. 
Com relação ao direito comparado, sobreleva ressaltar que até a entrada em vigor do atual Código Civil pátrio, poder-se-ia afirmar que todos os Códigos Civis da América Latina haviam adotado a orientação do art. 1.384 do Código Civil francês. ${ }^{410}$

Nesse sentido impera, nas referidas codificações, uma presunção juris tantun de culpa dos genitores pelos atos ilícitos de seus filhos menores, com possibilidade de prova, por parte dos pais da inexistência de negligência na educação dos seus descendentes para afastar o dever de indenizar, ou seja, o titular da autoridade parental exonera-se do dever de ressarcir, desde que prove que o fato danoso não poderia ser impedido, apesar de ter tomado todas as providências necessárias a fim de evitá-lo. ${ }^{411}$

Essa estrutura de responsabilidade, fundamentada na culpa, ainda que presumida, é prevista no Código Civil da Espanha, em seu art. 1.903, pelo atual Código Civil italiano, em seu art. 2.048 e pelo de Portugal, em seu art. 491, inobstante contenha um dispositivo mais genérico, atinente à responsabilidade civil pelo fato de outrem. ${ }^{412}$

É interessante notar que a legislação civilista portuguesa, em seu art. 494, diferencia as consequências do ato ilícito, de acordo com o elemento subjetivo do ofensor. Vale dizer, se o causador do prejuízo agiu apenas com culpa, o valor da indenização, por equidade, poder ser estabelecido em montante inferior ao dano, desde que presentes outros requisitos, tais como, o grau de culpabilidade do agente, a situação financeira das pessoas envolvidas e outras circunstâncias peculiares ao caso. Por outro lado, caso o fato danoso

\footnotetext{
${ }^{410}$ Pontes de Miranda compara os artigos $1.384 \S 2^{\circ}$ do Code Civil com o $\S 832$ do B.G.B e disserta que este último dispositivo é mais técnico que aquele, sendo mais abrangente, pois prevê de uma forma genérica a responsabilidade daquele que por lei ou contrato tenha o dever de vigilância em relação a uma pessoa que em razão de sua menoridade, ou a seu estado físico ou intelectual precisa ser vigiada. O ponto fulcral da crítica cingi-se na falta de previsão expressa da responsabilidade civil do tutor no Código Napoleão. PONTES DE MIRANDA, Francisco Cavalcanti. Fontes e evolução do direito civil brasileiro, cit., p. 429.

${ }^{411}$ Munir Karan, ao tratar da responsabilidade dos pais pelo fato do filho menor no sistema italiano, assenta que: "Condição de responsabilidade dos pais, fundada no art. 2.048, é a de que o filho não emancipado seja capaz de entender e de querer. Se o menor, em razão da idade ou de enfermidade, carece de entendimento ou de vontade, os genitores respondem pelo fato danoso na condição de pessoas encarregadas da vigilância de incapazes, segundo a norma do art. 2.047, §, $1^{\circ}$, do CC”. KARAM, Munir. op. cit., v. 65, p. 394-395. LIMA, Alvino. A responsabilidade civil pelo fato de outrem. 2. ed. rev. e atual. por Nelson Nery Jr. São Paulo: Ed. Revista dos Tribunais, 2000. p. 273.

${ }^{412}$ KARAM, Munir. op. cit., v. 65, p. 396. In verbis, o art. 491 do Código Civil português dispõe que: "As pessoas que, por lei ou negócio jurídico, forem obrigadas a vigiar outras, por virtude de incapacidade natural destas, são responsáveis pelos danos que elas causem a terceiros, salvo se mostrarem que cumpriram o seu dever de vigilância ou que os danos se teriam produzido ainda que o tivessem cumprido".
} 
tenha sido cometido com dolo, o montante a ser indenizado deverá corresponder à extensão do prejuízo. ${ }^{413}$

Não se pode olvidar, entretanto, como já referido, que a responsabilidade objetiva, no sistema civil atual brasileiro, por expressa previsão legal, é dos pais e não dos causadores diretos dos danos, de forma que será necessária a prova de culpa do filho menor, ainda que por ficção jurídica ou equiparação, no momento da prática do ato lesivo, para a eclosão da responsabilidade civil de seus genitores. É dizer, os pais somente responderão pelos ilícitos culposamente ocasionados por seus descendentes. ${ }^{414}$

A culpa, em sentido amplo, abrangendo o dolo ou a culpa em sentido estrito, apesar de ser requisito imprescindível para a responsabilidade civil subjetiva, não é absolutamente necessária em todas as situações para o surgimento da obrigação de indenizar porque, como é cediço, a responsabilidade civil pode advir tanto da teoria subjetiva, em que se busca a culpa, como da teoria objetiva, circunstância em que esse elemento não é considerado fundamental. ${ }^{415}$

No entanto, esse elemento é de definição extremamente complexa a ponto de muitos doutrinadores civilistas negarem a possibilidade de sua conceituação. ${ }^{416}$

Savatier conceitua:

"A culpa (faute) é a inexecução de um dever que o agente podia conhecer
e observar. Se efetivamente o conhecia e deliberadamente o violou,
ocorre o delito civil ou, em matéria de contrato, o dolo contratual. Se a
violação do dever, podendo ser conhecida e evitada, é involuntária,
constitui a culpa simples, chamada, fora da matéria contratual, de quase
delito" ${ }^{177}$

${ }^{413}$ KARAM, Munir. op. cit., v. 65, p. 396.

${ }^{414}$ DIREITO, Carlos Alberto Menezes; CAVALIERI FILHO, Sérgio. op. cit., p. 201; COELHO, Fábio Ulhoa. Curso de direito civil, cit., v. 2, p. 372.

415 “.... estágio atual da responsabilidade civil pode justamente ser descrito como um momento de erosão dos filtros tradicionais da reparação, isto é, de relativa perda de importância da prova da culpa e da prova do nexo causal como obstáculos ao ressarcimento dos danos na dinâmica das ações de ressarcimento. Tomese, de início, o caso - ou acaso - da culpa". SHREIBER, Anderson. op. cit., p. 11.

${ }^{416}$ DIAS, José de Aguiar. Da responsabilidade civil, cit., v. 1, p. 109.

${ }^{417}$ SAVATIER, René. Traité de la responsabilité civile en droit français. Paris: LGDJ, 1939. t. 1, n. 4, p. 5. 
Agostinho Alvim assevera que, ao se analisar a culpa, pode-se vislumbrar a existência de dois elementos, quais sejam, o dever violado (elemento objetivo); e a imputabilidade do agente (elemento subjetivo). ${ }^{418}$

Alvino Lima afirma que a definição de culpa, como um dos elementos do ato ilícito, é dependente do estabelecimento da conduta normal da pessoa, adaptada à vida social. A atuação culposa depende sempre do cotejo entre a conduta praticada pela pessoa e aquela que praticaria o "homem prudente, normal, avisado". Para ele "culpa é um erro de conduta, moralmente imputável ao agente e que não seria cometido por uma pessoa avisada, em iguais circunstâncias de fato”. Em sua obra, Alvino Lima repudia a concepção de culpa desprovida do elemento imputabilidade moral. Ou seja, o alienado, de acordo com a sua conceituação de culpa, não praticaria conduta culposa. Aduz, também, que a opinião dominante nega cabalmente a culpa desprovida da imputabilidade moral. É a teoria clássica. $^{419}$

Dessa forma, para essa teoria clássica, os danos causados pelas pessoas sem discernimento, em geral, não eram ressarcidos, com exceção da responsabilidade de seus guardas. ${ }^{420}$

Clóvis Bevilaqua conceitua a culpa, enfatizando o seu elemento objetivo, aduzindo que: "Culpa, em sentido lato, é toda violação de um dever jurídico", 421

Os doutrinadores alemães vislumbram a culpa como um fato exclusivamente moral, compreendendo o dolo (Vorsatz), que significa a vontade direcionada a um resultado proibido, com consciência, e a culpa advinda do direito romano, compreendida como a inobservância de um dever de cuidado na vida negocial, cuja atenção adequada impediria o resultado danoso, não desejado pelo sujeito. Sobreleva ressaltar que os autores alemães servem-se do critério do bonus pater familias. ${ }^{422}$

Sinteticamente e ante o exposto, é imperioso reconhecer que há, classicamente, duas correntes diversas de culpa. Inobstante alguns autores sustentarem que a culpa deva ser averiguada in concreto, vale dizer, que se deve considerar a consciência do causador do

\footnotetext{
${ }^{418}$ ALVIM, Agostinho. Da inexecução das obrigações e suas conseqüências jurídicas. 5. ed. São Paulo: Saraiva, 1980. p. 246.

${ }^{419}$ LIMA, Alvino. Da culpa ao risco, cit., p. 42-51.

${ }^{420}$ Id. Ibid., p. 69.

${ }^{421}$ BEVILAQUA, Clovis. Código Civil dos Estados Unidos do Brasil, cit., v. 4, p. 214.

${ }^{422}$ AMARAL NETO, Francisco dos Santos. op. cit., v. 65, p. 354.
} 
dano, buscar o seu íntimo, outros escritores, como os irmãos Mazeud, preconizam que a culpa precisa ser apreciada in abstrato, cotejando a conduta do agente com o comportamento normal das pessoas, em geral, inseridas nas mesmas situações dos eventos danosos. $^{423}$

A despeito dessas observações, é mister reconhecer que a culpa, em nosso entender, muitas vezes é confundida com a imputabilidade por alguns doutrinadores civilistas, ${ }^{424} \mathrm{de}$ modo que sentenciam que o menor não praticaria ato culposo porquanto não seria detentor de discernimento. ${ }^{425}$ Essa assertiva levaria o intérprete, em tese, a reconhecer ser impossível a responsabilidade civil do representante legal do incapaz, posto que, apesar de objetiva, dependeria, sempre, da conduta culposa do causador direto do dano.

No entanto, o sistema jurídico pátrio diferencia esses dois fenômenos jurídicos, distinção que pode ser melhor visualizada pelo estudo da teoria do crime, no direito penal, o que conduziria o hermeneuta, conseguintemente, a aceitar o fato do sistema jurídico prever a possibilidade da prática de ato culposo ou doloso, por parte incapaz, elidindo-se, dessa forma, alguns pensamentos doutrinários que chegam até a considerar que o ato do menor se enquadraria melhor ao caso fortuito ou à força maior. ${ }^{426}$

\footnotetext{
${ }^{423}$ VALLER, Wladimir. Responsabilidade civil e criminal nos acidentes automobilísticos. 4. ed. Campinas/SP: Julex, 1993. t. 1, p. 17.

424“"No capítulo 1, já nos manifestamos a respeito da responsabilização e imputabilidade do amental, quanto à responsabilização de seu próprio patrimônio, para o qual remetemos o leitor. Anteriormente falamos do mesmo dispositivo, que é genérico com relação a todos os incapazes (art. 928). Acrescentemos, contudo, que, assim como os menores impúberes, aos que falta o devido discernimento não cabe questionar aspectos de culpa, porque são inimputáveis...”. VENOSA, Silvio de Salvo. Direito civil: responsabilidade civil. 8. ed., cit., v. 4, p. 83. GOMES, Orlando. Obrigações. 15. ed. Rio de Janeiro: Forense, 2000. p. 348. Juan Espinoza Espinoza, por outro lado, ao comentar os artigos do Código Civil peruano que tratam da responsabilidade civil do incapaz, assevera que: "Debe de distinguirse, entonces el elemento de la imputabilidad del de la culpa (como perteneciente al elemento, factor de atribuición). El análisis de la culpa, obviamente si se entiende a la misma de manera objetiva, no tiene como objeto 'el componente psíquico de la conducta del autor'. El análisis de la culpa 'se refiere a la desconformidad de la conducta, respecto de un canon de comportamiento socialmente dado o establecido normalmente"'. ESPINOZA ESPINOZA, Juan. La influencia de la experiencia jurídica italiana en el Código Civil peruano en matéria de responsabilidad civil. Revista de la Facultad de Derecho de la Pontificia Universidad Católica del Perú, Lima, n. 56, p. 739, dic. 2003.

${ }^{425 ، . . . . s e ~ a ~ r e s p o n s a b i l i d a d e ~ d o ~ p a i ~ p r e s s u p o ̃ e ~ a ~ p r a ́ t i c a ~ d e ~ a t o ~ i l i ́ c i t o ~ p e l o ~ f i l h o, ~ i s t o ~ e ́, ~ a ~ a c ̧ a ̃ o ~ o u ~ o m i s s a ̃ o ~}$ voluntária, negligência ou imprudência, é lógico que não há responsabilidade paterna enquanto o filho não tiver capacidade de discernimento. Um menor de quatro anos não sabe o que faz. Se a outrem causa dano, não se pode dizer que agiu culposamente; se não há culpa, ato ilícito não praticou; se não cometeu ato ilícito, o pai não responde pela reparação do dano, porque a responsabilidade indireta supõe a ilicitude no ato de quem causa prejuízo". GOMES, Orlando. op. cit., p. 348.

426، Imaginemos, por exemplo, a hipótese de menor ou amental que se lança à frente do veículo em movimento, inopinadamente, em via de trânsito rápido, procurando o suicídio: a situação deve ser equiparada ao caso fortuito ou força maior sob pena de o sistema albergar iniqüidade". VENOSA, Silvio de Salvo. Direito civil: responsabilidade civil. 8. ed., cit., v. 4, p. 83.
} 
Realmente, para a doutrina penalista, de acordo com a teoria finalista do crime, consagrada pelo sistema penal brasileiro com a reforma do Código Penal de 1984, a conduta doloso ou culposa é estudada em um momento diverso da imputabilidade (capacidade de entender e de querer), sendo esta averiguada no momento da perquirição da culpabilidade. $^{427}$

${ }^{427} \mathrm{O}$ estudo do fenômeno crime, pode ser realizado analisando-se duas principais teorias, quais sejam, a clássica e a finalista. A teoria clássica, que para muitos era a perfilhada por nosso sistema até a reforma do Código Penal de 1984, preconiza que o conceito analítico de crime deveria ser analisado a partir do estudo de três elementos: fato típico, antijurídico e culpável. Obrigatoriamente, esses três elementos deveriam estar presentes, porquanto o dolo e a culpa estariam inseridos no elemento culpabilidade. Por outro lado, a teoria finalista (de Hans Welzel), que como já referido teria sido aquela adotada pelo legislador com a mencionada reforma penal, defende a tese de que crime é fato típico e antijurídico, sendo que a culpabilidade, de acordo com a corrente bipartida finalista, seria apenas um pressuposto de aplicação da pena e não elemento integrante do delito ou, para muitos finalistas (defensores da corrente tripartite) crime é fato típico, antijurídico e culpável. A diferença principal entre os finalistas e os clássicos é que para os primeiros, o dolo e a culpa integrariam a conduta, que seria o primeiro requisito a ser averiguado do elemento fato típico. Já para os clássicos ou causalistas, o dolo e a culpa estariam dentro da culpabilidade, não tendo vínculo imediato com a conduta que, para esta corrente, seria apenas a exteriorização ou abstenção de um comportamento sem qualquer finalidade. No entanto, qualquer que seja a corrente adotada, o elemento imputabilidade, que é a capacidade psíquica de entender o caráter ilícito de um fato ou de comportar-se de acordo com esse entendimento, seria diferente tanto da conduta, quanto do dolo e culpa, sendo inclusive estudados em momentos distintos. Neste sentido, são as palavras de Guilherme de Souza Nucci que, ao tratar do conceito analítico de crime, dispõe que: "analítico: é a concepção da ciência do direito, que não difere, na essência do conceito formal. Trata-se de uma conduta típica, antijurídica e culpável, vale dizer, uma ação ou omissão ajustada a um modelo legal de conduta proibida (tipicidade), contrária ao direito (antijuridicidade) e sujeita a um juízo de reprovação social incidente sobre o fato e seu autor, desde que existam imputabilidade consciência potencial da ilicitude e exigibilidade e possibilidade de agir conforme o direito. Justamente quanto ao conceito analítico é que se podem encontrar maiores divergências doutrinárias. Há quem entenda ser o crime, do ponto de vista analítico: a) um fato típico e antijurídico sendo a culpabilidade apenas pressuposto de aplicação da pena (René Ariel Dotti, Damásio de Jesus, Julio Fabbrini Mirabete, Celso Delmanto, Flávio Augusto Monteiro de Barros, entre outros); b) um fato típico, antijurídico, culpável e punível (Basileu Garcia, Muñoz Conde, Hassemer, Bataglini, Giorgio Marinucci e Emili Dolcini, entre outros); c) um fato típico e culpável, estando a antijuridicidade ínsita ao próprio tipo (Miguel Reale Júnior, entre outros adeptos da teoria dos elementos negativos do tipo); d) fato típico, antijurídico e punível, constituindo a culpabilidade a ponte que liga o crime à pena (Luiz Flávio Gomes); e) um fato típico, antijurídico e culpável. Nesta corrente que é majoritária, no Brasil e no exterior, e com a qual concordamos, dividem-se finalistas (Assis Toledo, Heleno Fragoso, Juarez Tavares, José Henrique Pierangeli, Eugenio Raul Zaffaroni, Fernando de Almeida Pedroso, Jair Leonardo Lopes, Cezar Roberto Bitencourt, Luiz Regis Prado, Rodolfo Tigre Maia, Antonio Luis Chaves Camargo, Jorge Alberto Romeiro, Luiz Luisi, David Teixeira de Azevedo, Rogério Greco, Fernando Galvão, Reinhart Maurach, Heinz Zipf, Claus Roxin - este último com um sistema próprio - entre outros), causalistas (Nélson Hungria, Frederico Marques, Aníbal Bruno, Magalhães Noronha, Paulo José da Costa Júnior, Vicente Sabino Júnior, Salgado Martins, Euclides Custódio da Silveira, Baumann, Mezger, entre outros) e os adeptos da teoria social da ação, que se propõe a ser uma tentativa de ajuste, num só quadro, dos principais aspectos do causalismo e do finalismo (Jescheck, Wessels, Schidt, Engish, Wolff, entre outros). O mais importante, nesse contexto, é perceber que a estrutura analítica do crime não se liga necessariamente à adoção da concepção finalista, causalista ou social da ação delituosa. Aliás, nesse sentido ensina o Ministro Victor Nunes Leal: "Tal como o causalismo, o finalismo vê no delito, analiticamente, uma ação típica, antijurídica e culpável. Mas, como este sistema advêm de uma concepção finalista da conduta, é na teoria da ação que se situa a diferença entre os dois sistemas" (LEAL, Victor Nunes. Prefácio. In: TAVARES, Juarez. Teorias do delito, p. XV). O causalismo busca ver o conceito de conduta despido de qualquer valoração, ou seja, neutro (ação ou omissão voluntária e consciente que exterioriza movimentos corpóreos). 
Deveras, de acordo com a teoria finalista da ação, o fato típico, primeiro elemento do crime, é formado pela conduta (dolosa ou culposa), pelo resultado, pelo liame causal e pela tipicidade, sendo que a culpabilidade é outro (último) elemento do crime (teoria tripartite), cujo conteúdo é formado pela imputabilidade, além da inexigibilidade de conduta diversa e da potencial consciência da ilicitude.

Nesse sentido, em razão da própria estrutura delitiva, a conduta necessariamente deverá ser dolosa ou culposa, uma vez que o sistema, de acordo com a teoria finalista, não permite esse elemento imprescindível para o crime desprovido do elemento subjetivo, ou seja, sem dolo e sem culpa não existe ação ou omissão humana e, sem esse requisito, não há o fato típico, sendo que a inexistência desse elemento ocasionará a impossibilidade de se impor uma medida de segurança ao inimputável.

De fato, ainda que a pessoa seja inimputável, desde que pratique fato típico e ilícito, o ordenamento lhe impõe uma sanção penal, ${ }^{428}$ qual seja, uma medida de segurança detentiva ou restritiva. Entretanto, cabe destacar e reiterar que para tanto o sujeito ativo do crime deverá ter praticado todos os elementos do fato típico, mormente a conduta dolosa ou culposa.

Assim, no que diz respeito à teoria do crime, ainda que analisemos a teoria clássica, resta claro que a conduta causadora do dano, que obrigatoriamente deverá ser culposa ou dolosa, pode ser visualizada independentemente da capacidade do agente entender e de querer. Dessa forma, pode-se concluir que uma coisa é a conduta produtora do prejuízo e outra, a possibilidade do lesante entender, ao menos juridicamente, a ilicitude de seu ato. A análise mais aprofundada da teoria do crime, em nosso entender, permite um diagnóstico mais preciso dos diversos elementos estruturadores da responsabilidade civil.

\footnotetext{
O dolo e a culpa estão situados na culpabilidade. Logicamente, para quem adota o causalismo, impossível se torna acolher o conceito bipartido de crime (fato típico e antijurídico), como ensina Frederico Marques, para quem o delito possui, objetivamente falando, dois elementos (tipicidade e antijuridicidade), mas não prescinde da parte subjetiva (culpabilidade) para formar-se completamente. O finalismo, de Hanz Welzel (que aliás sempre considerou o crime fato típico, antijurídico e culpável, em todas as suas obras), crendo que a conduta deve ser valorada, porque se trata de um juízo de realidade, e não fictício, deslocou o dolo e a culpa da culpabilidade para o fato típico. Assim, a conduta, sob o prisma finalista, é a ação ou omissão voluntária e consciente, que se volta a uma finalidade”. NUCCI, Guilherme de Souza. Código Penal comentado. 5. ed. São Paulo: Ed. Revista dos Tribunais, 2005. p. 111-112.

428،Pressupostos para aplicação da medida de segurança: tratando-se, como afirmado, de uma medida restritiva de direitos ou da liberdade, portanto uma forma de sanção penal, é imprescindível que o agente tenha praticado um injusto, vale dizer, um fato típico e antijurídico (crime, do ponto de vista objetivo, para a doutrina tradicional)". NUCCI, Guilherme de Souza. op. cit., p. 437.
} 
Dessa forma, uma vez que a culpa, em razão de suas consequências jurídicas, deve ter um conceito unívoco, acreditamos que o sistema, diante das considerações acima efetuadas, tenha optado por seu conceito abstrato, não se podendo falar, dessa forma, em caso fortuito ou força maior, em caso de ato ilícito praticado por inimputável.

A questão atinente à autoridade dos pais emerge translúcida diante do conteúdo do poder familiar, ${ }^{429}$ como já visto, que se revela por meio de direitos e deveres dos pais em relação à pessoa e bens dos filhos, de acordo com o art. 1.634 do atual Código Civil. Esse poder familiar impõe aos genitores os deveres de sustento, vigilância, orientação e formação, ${ }^{430}$ sempre com o objetivo de atender ao melhor interesse da criança ou do adolescente.

Dessarte, se por qualquer razão for o genitor suspenso ou destituído do poder familiar, não será mais o responsável civil pelos atos danosos que seu filho venha a praticar, porque cessada estará a sua autoridade.

No que tange ao vocábulo companhia, acreditamos haver em parte da doutrina e jurisprudência, ${ }^{431}$ data venia, confusão terminológica em relação ao conteúdo dessa expressão jurídica. De fato, essa palavra (companhia) ${ }^{432}$ não pode ser interpretada para significar, apenas, a circunstância fática de estar alguém momentaneamente ao lado de outrem, ou ainda, a convivência contínua e diária entre pessoas.

Assim, se imperasse essa interpretação restritiva ao vocábulo supracitado, os pais poderiam alegar a exclusão da responsabilidade caso saíssem de casa, deixando o seu filho

\footnotetext{
429، O termo autoridade previsto em lei significa que o filho está sob o poder familiar de seu pai, que o pupilo está sob a tutela e o curatelado, sob a curatela. A autoridade, portanto, não é matéria de fato, mas sim de direito. Não sai da autoridade paterna o filho que está com a mãe em razão da guarda judicial, pois persistem os direitos e deveres do pai, no tocante à educação, aos alimentos, à instrução e mesmo ao afeto. Entretanto, em situação de perda ou suspensão do poder familiar, deixa o genitor de ter autoridade sob o menor, e, se a perda ocorrer, a autoridade não mais será recuperada; mas, se apenas ocorrer suspensão, a autoridade, após certo tempo, será readquirida". SIMÃO, José Fernando. Responsabilidade civil incapaz, cit., p. 162-163.

${ }^{430}$ RIZZARDO, Arnaldo. Responsabilidade civil, cit., p. 113.

${ }^{431}$ SIMÃO, José Fernando. Responsabilidade civil incapaz, cit., p. 164-165; VENOSA, Silvio de Salvo. Direito civil: responsabilidade civil. 8. ed., cit., v. 4, p. 80-81; DIREITO, Carlos Alberto Menezes; CAVALIERI FILHO, Sérgio. op. cit., p. 205. Neste sentido: "Ilegitimidade ad causan - Responsabilidade civil - Ação ajuizada contra o pai - Dano causado por menor relativamente incapaz - Filho de pais separados e que estava sob a guarda da mãe - ilegitimidade de parte do pai - Ação extinta quanto a este Inteligência do art. 1.521, I, do CC - Recurso improvido quanto ao tema" (1 $1^{\circ}$ TACIVSP - Ap. Sum. 1026759-9, 29-1-2002, 7 7 Câmara de Férias de Janeiro de 2002 - Rel. Sebastião Alves Junqueira)".

${ }^{432}$ De acordo com o dicionário Aurélio, a palavra companhia significa: "Ato de acompanhar. Aquilo ou aquele que acompanha. Trato íntimo, convivência, convívio...”. FERREIRA, Aurélio Buarque de Holanda. Novo Aurélio século XXI: o dicionário da língua portuguesa. 3. ed. Rio de Janeiro: Nova Fronteira, 1999. p. 511.
} 
menor com a empregada doméstica e viesse o infante a furar o olho do amigo em uma brincadeira. $^{433}$

Nessa circunstância, fica evidente que os genitores, a despeito de não estarem faticamente na companhia do filho menor, no momento do evento danoso, são responsáveis pelos ilícitos que o filho pode cometer na esfera de direitos de outrem, haja vista a essência jurídica que a expressão companhia possui. ${ }^{434}$

A mesma resposta jurídica, em nossa opinião, deve ser conferida em caso de pais separados com filho menor, ainda que o regime de guarda unilateral tenha sido o estabelecido por ocasião da ruptura da sociedade conjugal. Impende considerar, outrossim, que pouco importa se a separação é judicial ou de fato, as consequências legais da conduta danosa do filho menor será a mesma para ambos os genitores que terão o mesmo dever de reparar os prejuízos. ${ }^{435}$

Com efeito, caso fosse atribuída essa exegese restritiva ao vocábulo supracitado, elidir-se-ia a responsabilidade do progenitor que não detivesse a guarda de seu filho menor, se este praticasse ato ilícito fora do período de visita. ${ }^{436}$ Tal interpretação vai de encontro com a evolução do sistema da responsabilidade civil que tem como escopo tutelar ao

\footnotetext{
${ }^{433}$ Interpretação estritamente gramatical e, a nosso ver, data venia, equivocada é conferida por Fábio Ulhoa Coelho ao asseverar que o termo companhia significa estar o progenitor no momento da prática do ato ilícito com o menor. São suas as seguintes palavras: “...Ainda no exemplo da responsabilidade dos pais por atos dos filhos menores: a imputação objetiva está sujeita ao pressuposto de que se encontrem estes sob a autoridade e em companhia daqueles (CC, art. 932, I). Não preenchido o pressuposto, portanto, os pais não têm a responsabilidade objetiva. Podem, porém, ser subjetivamente responsabilizados se a vítima provar a culpa deles no evento danoso. Imagine que Antonio empreste o carro para seu filho menor Benedito dirigir. Evidentemente, Benedito não é habilitado, porque não tem idade mínima para isso (18 anos). Se ele causar acidente de trânsito sem estar na companhia de Antonio, não se atende ao pressuposto legal de atribuição de responsabilidade objetiva aos pais por atos de filhos menores. Mas Antonio poderá ainda ser responsabilizado por culpa, já que incorreu num ato ilícito ao emprestar o automóvel ao filho". COELHO, Fábio Ulhoa. Curso de direito civil, cit., v. 2, p. 344.

434“"A companhia é um elemento fático, mais que jurídico. Entretanto, não é meramente fático. Se assim fosse, só seria responsável o pai que estivesse na presença física do filho no momento em que este causou o dano. A companhia não é presença física e, dessa forma, o pai que viaja a trabalho continua responsável pelos atos de seu filho, pois mantém sua autoridade e companhia". SIMÃO, José Fernando. Responsabilidade civil incapaz, cit., p. 163.

${ }^{435}$ Para fortalecer este pensamento, interessante se torna trazer à colação o art. 18, da Convenção Internacional dos Direitos da Criança de 1989, que aduz: "os Estados Partes envidarão os seus melhores esforços a fim de assegurar o reconhecimento do princípio de que ambos os pais têm obrigações comuns com relação à educação e ao desenvolvimento da criança. Caberá aos pais ou, quando for o caso, aos representantes legais, a responsabilidade primordial pela educação e pelo desenvolvimento da criança. Sua preocupação fundamental visará ao interesse maior da criança". (grifos nossos).

${ }^{436}$ Entendem contrariamente, no sentido de que a ruptura da sociedade conjugal e o estabelecimento da guarda unilateral ocasionam a irresponsabilidade do genitor não guardião, caso o ato lesivo seja praticado fora do período de visita. RIZZARDO, Arnaldo. Responsabilidade civil, cit., p. 113; SIMÃO, José Fernando. Responsabilidade civil incapaz, cit., p. 163.
} 
máximo a vítima, razão pela qual entendemos deve ser rechaçada. É imperioso reconhecer, também, que, apesar de não ter a guarda do filho, o genitor não guardião continua detentor do poder familiar, ${ }^{437}$ devendo participar, consequentemente, da educação de seu filho, transmitindo-lhe os valores morais necessários e consentâneos com a sociedade.

É mister ressaltar, também, que a educação, como um dos deveres impostos pelos detentores do poder familiar, deve ser exercida com extrema responsabilidade, porque seus reflexos desencadeiam-se pelo resto da vida das pessoas, modelando os indivíduos que se comportarão de acordo com o que lhes foi ensinado. ${ }^{438}$

Demais disso, o Código Civil brasileiro não condicionou, diferentemente do previsto no Código Civil francês, em seu art. 1.384, alínea 4, a responsabilidade dos pais à circunstância da coabitação, mas tão somente pela infração implícita do dever de vigilância. $^{439}$

\footnotetext{
${ }^{437}$ Nesse sentido: "Civil e processual civil - Responsabilidade civil dos pais por ato de filho menor - Acidente de trânsito com vítima fatal - Pais separados de fato - Princípio da identidade física do juiz - Preliminar rejeitada - Poder familiar e autoridade sobre o filho menor - Dano moral e material - Pensão mensal - Termo final Recurso parcialmente provido. 1) Férias constituem exceção legal ao princípio da identidade física do juiz, autorizando a prolatação da sentença por substituto; 2) O 'Poder Familiar', mesmo na hipótese de separação dos pais permanece, não sendo razoável que um cônjuge, apenas porque separado do outro, possa se eximir integralmente da responsabilidade pelos atos de seu filho menor, salvo em situações excepcionais, de nenhuma ingerência em sua criação; 3) $\mathrm{O}$ reconhecimento da responsabilidade civil do pai por ato de seu filho menor não exclui, entretanto, a da mãe, ainda que separados de fato, eis que a autoridade sobre os filhos nem sempre implica proximidade física; 4) Reconhecido o dano moral, o quantum indenizatório deve ser proporcionalmente fixado considerando a condição sócio-econômica da vítima, a capacidade econômica do ofensor, a natureza e extensão do dano, o grau de culpa do autor, não devendo a reparação, pois, exorbitar da adequação que nos ditam os expressivos julgados de nossos Tribunais Superiores; 5) A indenização, no caso de homicídio, consiste no pagamento de despesas com o tratamento da vítima, seu funeral e o luto da família, bem como na prestação de alimentos às pessoas a quem o defunto os devia - interpretação do art. 948 do Código Civil Brasileiro; 6) Consoante precedentes do Superior Tribunal de Justiça, o termo final da pensão por morte é o da data em que a vítima completaria sessenta e cinco anos de idade, cujo montante, no entanto deve ser reduzido pela metade depois da data em que ela atingiria vinte e cinco anos de idade; 7) Recurso parcialmente provido" (TJAP Acórdão 254105, 18-12-2006, Câmara Única - Rel. Dês. Mello Castro).

${ }^{438}$ Jean-Pierre Lebrun, em entrevista nas páginas amarelas da revista veja, de 9 de dezembro de 2009, expõe que o comportamento dos pais influenciam demasiadamente na formação de seus filhos e aduz, ainda, que o ser humano é o único animal que não nasce humano, ele se torna humano com o passar dos tempos por meio de um bom ambiente familiar com genitores que tenham a capacidade de fazer os filhos crescer. LEBRUN, Jean-Pierre. op. cit.

${ }^{439} \mathrm{O}$ art. 1114 do Código Civil argentino assevera, por outro lado, que: "El padre y la madre son solidariamente responsables de los daños causados por sus hijos menores que habiten con ellos, sin perjuicio de la responsabilidad de los hijos si fueran mayores de diez años. Em caso de que los padres no convivan, será responsable el que ejerza la tenencia del menor, salvo que al producirse el evento dañoso el hijo estuviere al cuidado de otro progenitor". Em comentários ao artigo mencionado, Jorge Mosset Iturraspe leciona que: "Veremos seguidamente los supuestos de menores que viven em compañia de sus padres y menores que, sometidos a patria potestad, viven fuera del hogar paterno-materno. Esta cuestión, que ahora analizamos, adquiere la máxima importancia. Y es así em la medida en que el artículo 1114 exige tres requisitos para esa responsabilidad paterna: a) Que se trate de menores causantes del dano injusto; b) que estén sometidos a patria potestad, y c) "que habiten com ellos", com sus progenitores". MOSSET
} 
Entretanto, há quem entenda que não podem ser responsabilizados os genitores, por ato danoso praticado por seu filho, na hipótese de este residir sozinho e em local desconhecido, por circunstâncias alheias à vontade de seus pais. ${ }^{440}$

Não obstante todas essas considerações acerca do termo companhia, outra ilação razoável, em nossa opinião, para o deslinde dessa questão, seria a interpretação de que nem todos os requisitos (menoridade, autoridade e companhia), elencados no inciso em comento, seriam imprescindíveis para o surgimento do dever de indenizar. Essa conclusão vai ao encontro da idéia de responsabilidade civil dos pais, pelos atos ilícitos praticados pelos filhos capazes economicamente dependentes, como será melhor detalhado.

Esse dispositivo, concernente à responsabilidade civil dos pais, deve ser estudado, para efeito de conferir maior precisão à nova sistemática obrigacional, juntamente com o artigo 928 do atual Código Civil, que também trouxe novidade antes não prevista pelo vetusto diploma civilista.

Com efeito, a preocupação do sistema na reparação da vítima foi tamanha que, seguindo outras codificações ${ }^{441}$ previu, expressamente, no artigo 928 do atual Código Civil, a responsabilidade subsidiária do incapaz, na circunstância de ter ocasionado dano e desde que os seus responsáveis não tenham, por alguma razão, o dever de indenizar ou não possuam patrimônio suficiente para tanto.

Nesse caso, o texto normativo é expresso ao mencionar que a indenização se pautará pelas regras da equidade, não podendo o menor, nem aqueles que dele dependam sofrer prejuízos em sua subsistência.

ITURRASPE, Jorge. De la responsabilidad de los padres de un menor de más de 10 años, de 10 a 21 años. In: MOSSET ITURRASPE, Jorge; D'ANTONIO, Daniel Hugo; NOVELLINO, Norberto José. Responsabilidad de los padres, tutores y guardadores. cit., p. 86. De maneira diferente, o Código Civil espanhol também não exige, em seu art. 1.903, expressamente, a coabitação para a eclosão da responsabilidade civil dos pais pelos atos ilícitos de seus filhos menores, impondo apenas que estes estejam sob a sua guarda. In verbis: "Los padres son responsables de los daños causados por los hijos que se encuentren bajo su guarda".

${ }^{440}$ VENOSA, Silvio de Salvo. Direito civil: responsabilidade civil. 8. ed., cit., v. 4, p. 78. Arnaldo Rizzardo assevera que: "Todavia, se o filho não se encontra na companhia de um dos progenitores por desídia do mesmo, por falta de cumprimento de suas obrigações, por abandono material, aí se mantém a responsabilidade, nada impedindo de conjecturar que o desvio de conduta do filho não aconteceria se assumida a educação, formação e vigilância do progenitor faltoso". RIZZARDO, Arnaldo. Responsabilidade civil, cit., p. 114.

${ }^{441}$ Nesse sentido: art. $2047, \S 2^{\circ}$ do CC italiano e o art. 489 do CC português. 
Equidade é um complemento imprescindível da justiça formal, sendo de utilização necessária toda vez que se torne impossível a implementação dessa justiça. Assim, a equidade é uma maneira de não se tratar com muita desigualdade as pessoas pertencentes a uma categoria essencial. ${ }^{442}$

A equidade tem por escopo impedir que a aplicação concreta da lei traga uma situação anti-isonômica, de forma a permitir que o juiz, diante das peculiaridades do caso, faça uma adaptação entre o texto escrito e as circunstâncias diversas que não puderam ser previstas pelo legislador. ${ }^{443}$

No entanto, deve ficar claro que, de acordo com essa nova regra do diploma civil, o incapaz poderá responder com o seu patrimônio próprio, por um ato seu praticado, mesmo que o sistema o considere incapaz de entender e de querer.

Essa situação tem a faculdade de ampliar as garantias da vítima de um ato ilícito que, na mesma circunstância, sobre a vigência do Código Civil de 1916, ficaria irressarcida. Vale dizer, ainda que o incapaz, autor da conduta lesiva, tivesse idoneidade patrimonial para indenizar a vítima de um ato ilícito por ele praticado, o sistema antecedente não permitia a reparação, porquanto havia uma preocupação maior em proteger o incapaz.

É conveniente esclarecer que o sistema anterior, ao Código Civil de 1916, previa a possibilidade do menor de 14 anos indenizar os prejuízos que causasse, uma vez que era considerado inimputável e, em razão disso, não poderia ser criminalmente punido, de

\footnotetext{
${ }^{442}$ Chain Perelman, ao explicitar a equidade, adverte que: "Se desejarmos levar em conta, na aplicação da justiça, duas características essenciais, se, ao tratarmos de modo idêntico dois seres que fazem parte da mesma categoria essencial, formos levados a tratar de modo demasiado diferente dois seres que fazem parte de uma mesma categoria essencial, determinada pela segunda característica, a equidade nos incitará a não levar em conta unicamente a primeira característica da justiça. Assim é que, tendo de contratar dois operários que fazem o mesmo trabalho, dos quais um seria solteiro e o outro pai de família numerosa, tratando-os da mesma forma, segundo a fórmula 'a cada qual segundo suas obras', nós os trataremos de forma demasiado diferente se desejarmos levar em conta a fórmula 'a cada qual segundo suas necessidades'. A equidade nos incitará a diminuir essa diferença. Mas se quisermos aumentar o salário do pai de família numerosa, deixaremos de tratar da mesma forma dois operários que fazem parte da mesma categoria essencial do ponto de vista de seu trabalho. Seja qual for a atitude adotada, seja qual for a medida em que se levará em conta uma ou outra fórmula de justiça, seremos obrigados a transgredir a justiça formal". PERELMAN, Chain. Ética e direito, cit., p. 36-37.

${ }^{443}$ DE RUGGIERO, Roberto. op. cit., v. 1, p. 49.
} 
acordo com o art. 10, $\S 1^{\circ}$ do Código Criminal de 1830, que foi a primeira lei no Brasil a conferir um racional sistema de ressarcimento do dano. ${ }^{444}$

Consagra-se, também, o princípio da proporcionalidade em virtude da previsão, como supracitado, do vocábulo equidade na seara da responsabilidade civil, sendo importante enfatizar que esta última hauriu a condição de instituto autônomo, perante o atual Código Civil e com principiologia própria, ${ }^{445}$ o que lhe confere a possibilidade de, por intermédio das cláusulas gerais, ${ }^{446}$ implementar esses preceitos que tanta importância adquiriram diante de nosso ordenamento jurídico.

Leciona Giselda Maria Fernandes Novaes Hironaka que:

\begin{abstract}
"No que diz respeito à responsabilidade do incapaz, avançou significativamente o novo Código, ao prever que ele responde pelos danos a que der causa, se seus responsáveis não tiverem a obrigação de indenizar ou se o patrimônio destes, desde que responsabilizados, não for suficiente para atender o reclamo da vítima. Trata-se de interessantíssimo avanço já conhecido de outras legislações estrangeiras, e que atende rigorosamente ao paradigma da pós modernidade que aponta o foco de atenção, do direito e da lei, para a pessoa da vítima e para a imprescindibilidade de refazimento de sua circunstância jurídicopatrimonial afetada pelo dano sofrido, mas, sobretudo, pelo refazimento de sua condição de titular do direito à dignidade constitucionalmente plasmada enquanto valor máximo da pessoa humana, pela imposição do dever indenizatório ao causador do dano, ainda que

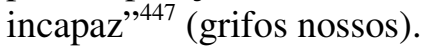

Dessarte, a nossa Carta Suprema reconheceu a necessidade da observância dos princípios da solidariedade social e da justiça distributiva, inseridos no seu art. $3^{\circ}$, incisos I e III, que preconizam serem objetivos fundamentais da República Federativa do Brasil a construção de uma sociedade livre, justa e solidária, bem como a erradicação da pobreza e

\footnotetext{
${ }^{444}$ Sobreleva ressaltar que: "O Projeto Clóvis Beviláqua seguiu a mesma orientação, equiparando o menor (sem distinção de idade) ao maior, para os efeitos das obrigações resultantes dos atos ilícitos. Depois se acrescentou: menor entre 14 e 21 anos. Por fim prevaleceu o critério entre 16 e 21 anos (CC/1916, art. 156). KARAM, Munir. op. cit., v. 65, p. 397.

${ }^{445}$ COSTA, Judith Martins. op. cit., p. 342-344.

${ }^{446}$ De acordo com o escólio de Perlingieri, o engendramento indireto dos princípios constitucionais "sempre acontecerá quando existir na legislação ordinária uma normativa específica, ou cláusulas gerais ou princípios expressos". PERLINGIERI, Pietro. Perfis do direito civil: introdução ao direito civil constitucional, cit., p. 11-12.

${ }^{447}$ HIRONAKA, Giselda Maria Fernandes Novaes. Responsabilidade pressuposta: evolução de fundamentos e de paradigmas da responsabilidade civil na contemporaneidade, cit. HIRONAKA, Giselda Maria Fernandes Novaes. Responsabilidade civil e contemporaneidade: retrato e moldura. In: ; SIMÃO, José Fernando (Coords.). Ensaios sobre responsabilidade civil na pós-modernidade. Porto Alegre: Magister, 2009. v. 2, p. 194-195.
} 
da marginalização, além da redução das desigualdades sociais e regionais, previsões que irradiam efeitos para todo o sistema e, no caso em debate, na área da responsabilidade civil.

Por conseguinte, a questão da responsabilidade civil ultrapassa a esfera individual da obrigação de indenizar os danos, espraiando critérios mais eficazes de reparação dos prejuízos, traduzidos por novos mecanismos de seguro social, em virtude da maior relevância para o sistema de critérios objetivos de ressarcimento de danos.

A guisa de conclusão, de se consignar que da conjugação dos dois dispositivos supracitados, emerge claro que se estabeleceu a responsabilidade principal dos pais e dos responsáveis, quando os filhos estiverem sob sua autoridade e em sua companhia, e secundária dos infantes, como lembra Rui Stoco,

“eles responderão pelos danos que causarem se os seus responsáveis não tiverem obrigação de fazê-lo, seja porque o incapaz se recuperou, foi emancipado, contraiu matrimônio, não esteja sob o poder familiar, ou qualquer outro motivo escorado na lei, ou, ainda, não disponha de meios suficientes para cumprir a obrigação". 48

O inciso II, do artigo 932 do atual Código Civil, trata da responsabilidade do tutor e do curador pelos atos ilícitos praticados por pupilos e curatelados que estiverem nas mesmas condições dos pais, vale dizer, sob sua autoridade e companhia.

Falecendo os pais, sendo julgados ausentes ou decaindo do poder familiar, os filhos menores são postos sob tutela (CC art. 1728). Por outro lado, estão sujeitos à curatela: os que, por enfermidade ou deficiência mental, não tiverem o necessário discernimento para

\footnotetext{
${ }^{448}$ STOCO, Rui. Tratado de responsabilidade civil. 6. ed. São Paulo: Ed. Revista dos Tribunais, 2004. p. 908. O sistema jurídico civil peruano, em seu art. 458, diferencia o menor capaz de discernimento daquele que não tenha a capacidade de entendimento e determinação, estabelecendo que aquele "responde por los daños y perjuicios que causa". De acordo com o escólio de Juan Espinoza Espinoza, ao comentar este artigo e outros que tratam da responsabilidade civil, tem-se que: "Sin mucha fatiga, se puede observar que un sujeto puede no ser imputable penalmente; pero sí a nível de responsabilidad civil". Assim, de acordo com o ordenamento jurídico em referência, a idade, por si só, não teria o condão de afastar a responsabilidade civil do menor, mas sim o seu desenvolvimento intelectual. Nesse sentido, continua o referido autor: "Si bien es cierto que el Art. $1974^{\circ}$ c.c., regula el estado de inconciencia transitorio, hay un común denominador com los artículos que regulan la responsabilidad civil de los denominados incapaces. Así, el Art. $458^{\circ}$ c.c. tiene que ser interpretado sistemáticamente com el Art. $1975^{\circ}$ c.c., que establece que, cuando el incapaz de ejercício con discernimiento ocasiona um daño, este es responsable en vía solidaria com su representante legal. Cuando el incapaz sin discernimiento es autor de un hecho dañoso, responde solo su representante legal (Art. $1976^{\circ}$ ), previéndose una indenización equitativa cuando la vícitima no haya podido obtener una reparación. Esta indemnización será autorizada por el juez en vista de la situación econômica de las partes (Art. 1977)". ESPINOZA ESPINOZA, Juan. op. cit., p. 738.
} 
os atos da vida civil; os que, por outra causa duradoura, não puderem exprimir a sua vontade; os deficientes mentais, os ébrios habituais e os viciados em tóxicos; os excepcionais sem completo desenvolvimento mental; os pródigos; o nascituro e o enfermo ou portador de deficiência física (CC arts. 1.767 e 1.779).

Como é cediço, tutor é denominação do representante legal dos menores postos sob tutela, enquanto o curador representa os interesses do maior incapaz nas situações previstas nos artigos acima referidos.

A lei atribui-lhes o poder de direção sobre o pupilo e o curatelado, bem como o dever de vigilância, tal qual aos pais em relação aos filhos menores, razão pela qual a responsabilidade desses representantes segue idêntica à responsabilidade paterna, diante da regra estabelecida no debatido art. 932, II, do atual Código Civil. Vale dizer, o tutor e o curador também são responsáveis pelos atos praticados pelos seus pupilos e curatelados, que se acharem nas mesmas condições. ${ }^{449}$

Os pressupostos são os estabelecidos no inciso I, do mesmo artigo 932, ou seja: que se encontrem sob a autoridade e companhia de seus representantes. Se o tutelado ou curatelado praticam ato danoso, nessas condições, o representante legal responderá pelos prejuízos causados a terceiros, nas mesmas circunstâncias em que os pais respondem pelos filhos menores.

Essa forma de responsabilidade dos tutores e curadores, nos moldes trazidos por nossa legislação, é muito criticada pela doutrina em razão de seu rigor, porquanto não teria o civilmente responsável, apesar de exercer um munus publicum, a possibilidade de elidir o seu dever de indenizar, demonstrando que tomou todas as cautelas necessárias para evitar que o dano ocorresse. Na prática, a única saída que restaria aos tutores e curadores, após indenizarem a vítima, seria a ação de regresso contra os pupilos e curatelados. ${ }^{450}$

Há inclusive a sugestão, por parte de alguns autores, de que o juiz, em vista da situação acima relatada, seja mais ponderado que com relação aos pais no momento de se responsabilizar os tutores e curadores. ${ }^{451}$

\footnotetext{
${ }^{449}$ DIREITO, Carlos Alberto Menezes; CAVALIERI FILHO, Sérgio. op. cit., p. 209-210.

${ }^{450}$ VENOSA, Silvio de Salvo. Direito civil: responsabilidade civil. 8. ed., cit., v. 4, p. 78.

${ }^{451}$ DIREITO, Carlos Alberto Menezes; CAVALIERI FILHO, Sérgio. op. cit., p. 210.
} 
No entanto, uma observação se mostra pertinente: se considerarmos o termo autoridade do inciso I supracitado como sinônimo do poder familiar, a responsabilidade civil do tutor ou do curador, por via de conseqüência, ressentiria sempre desse pressuposto para a eclosão do dever de indenizar, porque não são eles detentores desse plexo de direitos e deveres. Insta ressaltar que o poder familiar cessa com a maioridade e a curatela, na maioria das vezes, é destinada aos maiores de idade, o que implica reconhecer que, apesar das semelhanças existentes entre esses dois institutos, há diferenças que não podem ser ignoradas. $^{452}$

Destarte, diante dessa constatação, poder-se-ia afirmar que o vocábulo autoridade, previsto no artigo em debate, não significa apenas poder familiar. A sua interpretação deve ser mais abrangente, sob pena de se inferir que o discutido artigo 932, II, é autodestrutivo. Contudo, outra ilação compatível com a idéia aqui defendida, de responsabilidade civil dos pais pelos atos ilícitos de seus filhos capazes, desde que dependentes economicamente, seria de que não é necessária a presença de todos os requisitos estabelecidos em cada um dos incisos do referido artigo para que possa surgir a responsabilidade civil indireta.

O inciso III, do artigo 932 do atual diploma civil, trata da responsabilidade do empregador ou comitente por ato de seus empregados, serviçais e prepostos. ${ }^{453}$

Assim, a título de esboço histórico, com relação à responsabilidade do patrão, amo ou comitente, a jurisprudência, na vigência do CC/1916, cuidou de dar uma interpretação diversa da expressamente prevista nos artigos 1.521, III, e 1.523 do Código Civil de $1916,{ }^{454}$ fixando a presunção de culpa do preponente, tendência que foi se pacificando por todo Brasil, até a edição da Súmula no 341 do STF, com os seguintes dizeres: "É presumida a culpa do patrão ou comitente pelo ato culposo do empregado ou preposto".

Deveras, na vigência do antigo Código Civil, a responsabilidade do empregador por fato do empregado caminhou por um longo trajeto até chegar aos moldes atuais. Inicialmente, vigorava a idéia da culpa in eligendo, que significava que o patrão deveria responder pelos atos do empregado, porquanto havia escolhido mal. No entanto, logo cedo

\footnotetext{
${ }^{452} \mathrm{MELO}$, Albertino Daniel de. A responsabilidade civil pelo fato de outrem nos direitos francês e brasileiro. 1. ed. Rio de Janeiro: Forense, 1972. p. 41.

${ }^{453}$ Esta responsabilidade abrange inclusive os atos dos empregados praticados contra os empregados na visão de Arnaldo Rizzardo, Responsabilidade civil, cit., p. 117.

${ }^{454}$ “Bastante censurado tem sido esse último dispositivo, dizendo-se dele haver sido arrancado a um Senado complacente pelo capitalismo brasileiro". MONTEIRO, Washington de Barros. Curso de direito civil: direito das obrigações: $2^{a}$ parte. 21. ed. São Paulo: Saraiva, 1987. p. 400.
} 
esse entendimento foi repelido, uma vez que se mostrou incompatível com a organização do trabalho e transformações econômicas. Posteriormente, adotou-se a presunção relativa de culpa para, finalmente, chegar à sua presunção absoluta, exteriorizada pela já referida súmula 341 do STF. ${ }^{455}$

Destarte, coerente e harmônico com o processo evolutivo da responsabilidade civil por fato de outrem, o referido artigo 932 previu que são responsáveis pela reparação o empregador ou comitente, por atos violadores ao direito causados por seus empregados, serviçais e prepostos, no exercício do trabalho que lhes competir, ou em razão dele. ${ }^{456}$ Fundamenta-se essa forma de responsabilidade objetiva, para alguns doutrinadores, na teoria do risco proveito, nos moldes alhures explicitado. ${ }^{457}$ Entretanto, entendemos que o fundamento imediato é a lei, que prevê expressamente a responsabilidade, neste caso, independentemente de culpa, e o fundamento mediato é a teoria do risco proveito.

Assim, é mister explicitar que a responsabilidade do empregador surge do poder de direção ou de hierarquia que possui em relação ao empregado, prepostos, serviçais e comitidos, ${ }^{458}$ o que significa dizer que o vínculo trabalhista, com seus quatro elementos, quais sejam, pessoalidade, não eventualidade, salário e subordinação, não é imprescindível para a eclosão da obrigação de indenizar, caso ocorra um dano. ${ }^{459}$

É dizer, para a exata fixação dos limites dessa responsabilidade, a doutrina assevera que o ponto fulcral consiste na existência de subordinação hierárquica, manifestada por

\footnotetext{
${ }^{455}$ DIREITO, Carlos Alberto Menezes; CAVALIERI FILHO, Sérgio. op. cit., p. 210-211.

456، Com o vigente Código, consoante já ressaltado, grande revelou-se a mudança. Não mais há presunção de culpa, e sim a culpa. Mais precisamente, dispensa-se falar em culpa, e tem-se unicamente a responsabilidade. Uma vez advindo o dano, que decorreu em razão de culpa do empregado ou preposto, ou do exercício puro e simples da atividade, é automática e obrigatória a incidência da responsabilidade. Inútil falar em possibilidade de provar o empregador que não falhou na vigilância, ou na atenção. Já vinha dominando essa ratio mesmo antes do vigente Código..." RIZZARDO, Arnaldo. Responsabilidade civil, cit., p. 118.

${ }^{457}$ DIREITO, Carlos Alberto Menezes; CAVALIERI FILHO, Sérgio. op. cit., p. 212.

${ }^{458}$ VENOSA, Silvio de Salvo. Direito civil: responsabilidade civil. 8. ed., cit., v. 4, p. 83. Caio Mario aduz que: "Quando o Código Civil (1916) foi elaborado, a timidez legislativa atuou, empecendo o desenvolvimento do princípio, com a ressalva de que era necessária a prova do concurso para o dano, com a culpa ou negligência do preponente". PEREIRA, Caio Mário da Silva. Instituições de direito civil. Contratos. Declaração unilateral de vontade. Responsabilidade civil, cit., v. 3, p. 391.

${ }^{459}$ Arnaldo Rizzardo entende que o conteúdo da preposição não compreende apenas aquele que realiza atividade em favor de outra pessoa, abarcando também aquele que empresta ou fornece bens para outras pessoas. Esse pensamento fundamentaria a súmula ${ }^{\circ} 492$ do STF, que trata da responsabilidade solidária das locadoras de veículos. Não obstante, o referido autor aduz que "todavia, nessa situação parece não existir uma relação de preposição propriamente dita. O locatário não é preposto do locador. Há a transferência da posse direta do bem. O fundamento está na maior segurança que se concede ao terceiro em ser ressarcido dos danos que vier a suportar pelo uso culposo do veículo". RIZZARDO, Arnaldo. Responsabilidade civil, cit., p. 119.
} 
meio do poder de direção do civilmente responsável, que dá ordens ao seu subordinado em clara situação de dependência, independentemente do empregado ser assalariado. ${ }^{460}$

Alvino Lima aduz que três requisitos são necessários para o surgimento da responsabilidade do empregador ou do comitente: “a) a existência de uma relação entre o civilmente responsável e o autor material do ato danoso; b) o caráter culposo do fato danoso; c) uma relação entre a função e o fato danoso". ${ }^{461}$

A Consolidação das Leis de Trabalho dá, em seu art. $2^{\circ}$, o conceito claro de empregador. "Considera-se empregador a empresa, individual ou coletiva, que, assumindo os riscos da atividade econômica, admite, assalaria e dirige a prestação pessoal de serviços". No parágrafo $1^{\circ}$, complementa: "Equiparam-se ao empregador, para os efeitos exclusivos da relação de emprego, os profissionais liberais, as instituições de beneficência, as associações recreativas ou outras instituições sem fins lucrativos, que admitirem trabalhadores como empregados".

Dessarte, empregador é quem contrata alguém para lhe prestar serviços, mediante contraprestação, em uma relação manifestada por subordinação hierárquica. ${ }^{462}$

Por outro lado, e para fechar o rol dos partícipes dessa específica forma de responsabilidade civil indireta, empregados são as pessoas que exercem atividades e funções de natureza mais econômica, enquanto os serviçais relacionam-se com a noção de trabalho doméstico, familiar. Os prepostos realizam trabalho subordinado em favor de alguém, existindo um poder de representação, em alguns casos. Enfim, sempre que houver subordinação e poder de direção de uma pessoa para outra, o superior hierárquico será responsável pelos atos daquele que dirige a prestação do serviço. ${ }^{463}$

Dessa forma, para fundamentar, também, essa espécie de responsabilidade civil indireta, é curial esclarecer que há uma presunção absoluta de que, por ser o patrão a parte mais forte na relação trabalhista, o empregado, de antemão, não tem idoneidade econômica suficiente para ressarcir os danos causados na provável vítima de um ato seu, razão pela qual o sistema confere ao patrão a responsabilidade objetiva e solidária, nesse caso.

\footnotetext{
${ }^{460}$ GONÇALVES, Carlos Roberto. Comentários ao Código Civil: parte especial: do direito das obrigações (artigos 927 a 965). Coord. Antonio Junqueira de Azevedo. São Paulo: Saraiva, 2003. p. 437.

${ }^{461}$ LIMA, Alvino. A responsabilidade civil pelo fato de outrem, cit., p. 67.

${ }^{462}$ RIZZARDO, Arnaldo. Responsabilidade civil, cit., p. 116.

${ }^{463}$ Id., loc. cit.
} 
Comitente, por seu passo, é aquele que contrata a comissão mercantil, ou seja, um contrato pelo qual a pessoa adquire e transfere bens, em seu próprio nome e responsabilidade, mas por ordem e conta de terceiro, recebendo como contraprestação uma remuneração, obrigando-se para com terceiros com quem contrata, nos precisos termos do art. 694 do atual Código Civil. No entanto, é imperioso reconhecer que a responsabilidade do comitente é pelos atos dos seus empregados, prepostos e serviçais e não pelos atos danosos do comissário, cujo negócio não responde o comitente por ser autônomo. ${ }^{464}$

Alguns doutrinadores, com a ratificação da jurisprudência, ${ }^{465}$ conferem uma interpretação extensiva aos requisitos deflagradores da responsabilidade civil do empregador, na medida em que anuem com a obrigação de indenizar os danos por parte do patrão, mesmo que o seu empregado tenha agido em completa falta de sintonia com as ordens que lhe foram passadas. Ou seja, nessa linha de pensamento, o vínculo que ligaria o causador material do dano e o civilmente responsável poderia ser extremamente tênue, ainda mais em razão do Código de Defesa do Consumidor e sua definição extremamente abrangente de fornecedor de produtos e serviços. ${ }^{466}$

Com efeito, a expressão “em razão dele”, prevista no inciso III, do art.932 do atual Código Civil, deve ser interpretada, de acordo com essa corrente mais rigorosa, no sentido de se permitir a responsabilização do empregador, desde que as funções exercidas pelo subordinado facilitem a produção do resultado danoso, não se importando se a conduta lesiva está relacionada com as funções do empregado. ${ }^{467}$

\footnotetext{
${ }^{464}$ RIZZARDO, Arnaldo. Responsabilidade civil, cit., p. 116.

${ }^{465}$ De acordo com decisão do STJ: "Responsabilidade civil. Roubo praticado por funcionário de estabelecimento bancário que vitimou outro empregado. Caso fortuito ou força maior afastados. Legitimidade passiva... I - Se o aresto recorrido enfrentou satisfatoriamente todas as questões submetidas ao seu conhecimento, ainda que de forma contrária ao interesse da parte, não há que se falar em omissão ou ausência de fundamentação. II - O banco é responsável civilmente pelo assalto praticado por seu funcionário contra outro colega de trabalho, durante o horário de expediente da vítima, que exercia atividade perigosa, sem que fossem tomadas quaisquer providências para minimizar o risco. III - É possível a intervenção desta Corte para reduzir ou aumentar o valor do dano moral apenas nos casos em que o quantum arbitrado pelo acórdão recorrido se mostre irrisório ou exagerado, o que não ocorreu no caso concreto". Resp. n 613.036/RJ, da Terceira Turma, j. 14/06/2004, DJU de $1^{\circ} .07 .2004$.

466، Assim, por exemplo, mesmo em feriado, se um veículo com o logotipo e as cores de uma empresa ocasiona danos, tudo é no sentido de que a atividade do causador do dano está relacionada com o emprego ou situação assemelhada, devendo assumir a responsabilidade a responsabilidade a pessoa jurídica decantada e divulgada no veículo causador do dano". VENOSA, Silvio de Salvo. Direito civil: responsabilidade civil. 8. ed., cit., v. 4, p. 84.

${ }^{467}$ GONÇALVES, Carlos Roberto. Comentários ao Código Civil: parte especial: do direito das obrigações (artigos 927 a 965), cit., p. 443; MONTEIRO, Washington de Barros. Curso de direito civil: direito das obrigações: $2^{\mathrm{a}}$ parte, cit., p. 401 . Esta extremada responsabilidade pode ser retratada, inclusive, por um
} 
É, nesse contexto, e com fundamento no princípio da proporcionalidade e da razoabilidade que entendemos viável a responsabilidade civil dos pais pelos atos de seus filhos capazes que vivam sob a dependência econômica de seus genitores.

De acordo com essa situação, há uma relação de sujeição, similar à dos prepostos, entre os progenitores e seus descendentes, ainda que absolutamente capazes, uma vez que são os primeiros detentores do poder econômico, no ambiente familiar, o que lhes confere a possibilidade de subordinar os interesses dos seus filhos aos seus, em virtude dessa maior capacidade financeira.

Os genitores, nessas condições, oportunizam os danos provocados por seus filhos, doando ou emprestando seus bens. Assim, se como foi explicitado, alguns doutrinadores e nossos tribunais conferem uma interpretação extensiva à expressão "em razão dele" para salvaguardar os interesses da vítima, é possível reconhecer que se harmoniza com o princípio da proporcionalidade a imposição do dever de indenização dos genitores nas circunstâncias defendidas, porquanto na relação entre pais e filhos há o elemento sujeição e oportunização do dano.

Outros autores, de forma diversa, já procuram conferir uma margem maior de possibilidade de isenção da responsabilidade dos empregadores, ${ }^{468}$ caso a conduta lesiva do empregado tenha sido praticada em cabal falta de harmonia entre o comportamento do agente e a função para a qual foi contratado. É a denominada normalidade do trabalho. Vale dizer que, para Carlos Alberto Menezes Direito e Sérgio Cavalieri Filho, "se o ato não for praticado no exercício da função ou em razão dela, inexiste conexão de tempo, de lugar de trabalho. Querer impor a condenação do patrão, nesses casos, é violar o texto da lei; é consagrar a teoria do risco integral, porquanto fica descaracterizada a própria relação de preposição, não havendo falar em responsabilidade do comitente". 469

\footnotetext{
julgado francês em que a Côrte de Cassação, Câmara Social, num aresto de 7 de janeiro de 1965, "declara que o operário, quando volta ao domicílio de seu patrão, depois de ter trabalhado a título de ajuda agrícola, para um cultivador - colocado à disposição deste pelo patrão habitual - se encontra, ao longo do trajeto que faz, sob a autoridade e a subordinação do patrão habitual. Por conseguinte, diz a Côrte, o acidente que ele causa no seu trajeto envolve a responsabilidade civil do seu empregador, e não a do beneficiário da ajuda". MELO, Albertino Daniel de. op. cit., p. 53.

${ }^{468}$ RIZZARDO, Arnaldo. Responsabilidade civil, cit., p. 118.

${ }^{469}$ DIREITO, Carlos Alberto Menezes; CAVALIERI FILHO, Sérgio. op. cit., p. 217. Em dissonância com este entendimento, tem-se a seguinte jurisprudência: "A circunstância de ter o acidente ocorrido num domingo, fora do horário de trabalho do empregado da empresa demandada, é irrelevante. O que é decisivo é que o motorista tenha acesso ao veículo causador do evento danoso, em razão do vínculo empregatício
} 
A fundamentação dessa forma de responsabilidade se expressaria, de acordo com a doutrina, na denominada teoria da substituição que alude que o empregador prolonga a sua atividade, ao recorrer aos serviços de seu empregado, sendo este um longa manus do patrão, ou seja, uma pessoa que o substitui no desempenho das inúmeras atividades empresariais, praticando atos em nome do empregador, responsabilizando este último pelos danos porventura ocasionados. ${ }^{470}$

Nesse cenário, e de acordo com as linhas gerais já traçadas, emerge translúcida que a responsabilidade civil dessas pessoas é objetiva, por expressa disposição legal, sendo curial esclarecer e reiterar, contudo, que os provocadores do ato lesivo devem ter atuado ao menos com culpa ${ }^{471}$ para a deflagração da obrigação de indenizar de seus patrões.

Dessa forma, comprovada a culpa do subordinado exsurge o dever de indenizar do empregador, em razão da adoção da responsabilidade objetiva, nos moldes do artigo 933 do atual Código Civil, restando-lhe poucas alegações em seu favor para elidir essa obrigação. Isto ocorre, como supracitado, uma vez que o nosso Direito, por meio da interpretação jurisprudencial que se tem dado à matéria, não impõe uma rigorosa relação funcional entre a atividade do empregado e a lesão perpetrada, dificultando sobremaneira a exclusão do dever de indenizar por parte dos empregadores. ${ }^{472}$

Parte da doutrina advoga que o patrão somente exonerar-se-á do dever de indenizar, se provar a ocorrência de caso fortuito, força maior ou que o ato lesivo é totalmente

existente. Estando comprovado que o evento decorreu de ato culposo do motorista, presume-se a coresponsabilidade do patrão". (Súmula 341 do STF) (TAMG, AP. 20.443, Boa Esperança, Rel. Humberto Theodoro).

${ }^{470}$ DIREITO, Carlos Alberto Menezes; CAVALIERI FILHO, Sérgio. op. cit., p. 212. Neste sentido, Arnaldo Rizzardo leciona que "há uma extensão do próprio empregador na pessoa de quem faz a atividade por ele. É como se ele executasse a obra, não passando o empregado de um instrumento, ou de uma longa manu do empregador. Já que impossível a execução pessoal das múltiplas funções que impõe a atividade, faz-se substituir por terceiros, a quem remunera”. RIZZARDO, Arnaldo. Responsabilidade civil, cit., p. 119. Em oposição a este entendimento encontramos as lições de Silvio Rodrigues ao lecionar que: "Entender que o empregado é mandatário do patrão, para responsabilizá-lo por atos daquele, é asserção ilógica, pois é óbvio que o patrão ou o pai não constituíram seus empregados e filhos mandatários com poderes para praticar atos ilícitos. Se o tivessem feito, sua responsabilidade não seria por fato de terceiro, mas por fato próprio". RODRIGUES, Silvio. Direito civil. 19. ed., cit., v. 4, p. 63.

${ }^{471}$ RIZZARDO, Arnaldo. Responsabilidade civil, cit., p. 120. Sobreleva ressaltar, também, que a Constituição federal de 1988, em seu art. 37, § 6º assim como o Código de Defesa do Consumidor e o próprio Código Civil de 2002, em seu art. 927, parágrafo único, diminuíram a utilidade do inciso em comento, uma vez que estabeleceu a responsabilidade objetiva direta sem a possibilidade da demonstração da inexistência de culpa por parte do autor material do dano, desde que as circunstâncias fáticas se subsumam aos regimes jurídicos referidos. Assim, na realidade, o dispositivo mencionado aplicar-se-ia aos casos de motoristas particulares, empregados domésticos e preposições eventuais. DIREITO, Carlos Alberto Menezes; CAVALIERI FILHO, Sérgio. op. cit., p. 213.

${ }^{472}$ DIREITO, Carlos Alberto Menezes; CAVALIERI FILHO, Sérgio. op. cit., p. 217. 
estranho ao desenvolvimento da atividade para o qual foi contratado o empregado. ${ }^{473}$ No entanto, como já relatado, muitos são os entendimentos de que a simples oportunização do dano já tem o condão de atribuir a responsabilidade ao empregador.

Impende destacar que a doutrina e a jurisprudência francesas, no que tange à responsabilidade do empregador, consagraram os princípios da transferibilidade e da unicidade do comitente. O princípio da transferibilidade se expressa no reconhecimento de que o preposto de alguém pode momentaneamente, dependendo das circunstâncias fáticas e jurídicas, tornar-se o preposto ocasional de outra pessoa com a transferência inclusive do dever de indenizar os eventuais danos ocasionados pelo empregado. ${ }^{474}$

Já o princípio da unicidade do comitente aduz: quando um preposto está ligado a várias pessoas, com um objetivo comum, que lhe conferem a atribuição de exercer uma mesma função, cada uma delas se faz representar pela outra, o que ocasiona a responsabilidade de todas pelos atos danosos praticados pelo preposto. ${ }^{475}$

Consideração deve ser feita, ainda, em relação à possível ciência da vítima quanto ao fato do preposto encontrar-se agindo contra as instruções do seu patrão e fora do expediente de trabalho. Nesse caso, não estará o empregador obrigado a reparar o dano, caso comprove que o lesionado sabia da atividade inadequada do preposto. ${ }^{476}$

Entretanto, impende esclarecer que predomina, em sede jurisprudencial, a teoria da aparência, com a orientação de ser suficiente a aparente competência do empregado para

\footnotetext{
${ }^{473}$ DIREITO, Carlos Alberto Menezes; CAVALIERI FILHO, Sérgio. op. cit., p. 217. É esse o pensamento de Arnaldo Rizzardo, ao dissertar que: "No entanto, não cabe exagerar na interpretação ou impor a responsabilidade em momentos de ausência da subordinação ou dependência". RIZZARDO, Arnaldo. Responsabilidade civil, cit., p. 118.

${ }^{474} \mathrm{Um}$ exemplo pode aclarar melhor esta questão referente ao princípio da transferibilidade: "A Côrte de Cassação, Câmara Criminal, num aresto de 16 de maio de 1961, para condenar um médico pelas conseqüências danosas de um homicídio involuntário, cometido por uma enfermeira, como resultado de erro na identificação de sangue, constata que, por escolha do médico, encarregado pessoalmente do tratamento e da vigilância do doente, a enfermeira tinha-lhe sido posta à disposição, pelo comitente habitual - uma clínica -, como auxiliar de uma operação cirúrgica efetuada pelo médico no doente. A Côrte fundamentou-se nos mesmos motivos dados pela jurisdição - Côrte de Apelação de Tolosa, de 7 de julho de 1960: as enfermeira tinha-se tornado o "preposto ocasional" do médico". MELO, Albertino Daniel de. op. cit., p. 52.

${ }^{475}$ Id. Ibid., p. 54.

${ }^{476}$ GONÇALVES, Carlos Roberto. Comentários ao Código Civil: parte especial: do direito das obrigações (artigos 927 a 965), cit., p. 443.
} 
eclodir a responsabilidade do patrão, ou seja, é considerada satisfatória a razoável aparência de estar o agente causador do dano no desenvolvimento de seu labor. ${ }^{477}$

Por fim, é curial esclarecer que o empregador, de acordo com o disposto no artigo 934, do Código Civil, terá ação de regresso em face do empregado, caso indenize dano perpetrado por este último.

O inciso IV, do artigo 932 em comento, dispõe a respeito da responsabilidade dos estabelecimentos de hotelaria, de albergue e de ensino.

O referido inciso também é importante para o deslinde do problema objeto do presente estudo, porque os filhos, nas condições de dependentes economicamente dos pais, ainda que capazes, coabitam, em muitos casos, com seus genitores, aproximando essas referidas circunstâncias fáticas com aquelas que se subsumem no disposto pelo inciso 932, IV, do atual Código Civil.

É romana a raiz histórica dessa espécie de responsabilidade hoteleira, ou seja, do período em que era imposta a obrigação ao capitão do navio, proprietário de estábulo ou hospedaria a ressarcir os prejuízos e furtos perpetrados por seus prepostos contra os seus clientes. $^{478}$

Dessa forma, consoante o referido inciso, respondem os donos de hotéis, hospedarias, casas ou estabelecimentos onde se albergue por dinheiro, mesmo para fins de educação, pelos danos causados a terceiros pelos seus hóspedes, moradores e educandos. Diferentemente dos outros incisos já referidos, esse tipo de responsabilidade civil indireta tem substrato contratual em boa parte de suas aplicações. ${ }^{479}$

Inicialmente, o artigo em comento deve ser interpretado de forma a abarcar todas as espécies de casas de internação de pessoas, dada a abertura conferida pelo dispositivo ao expressar "casas ou estabelecimentos onde se albergue por dinheiro", destarte, pode-se incluir, nessa generalidade estabelecida pela lei, os proprietários de colégios, hotéis, motéis, asilos, casas de repouso, hospitais, sanatórios, etc. ${ }^{480}$

\footnotetext{
${ }^{477}$ GONÇALVES, Carlos Roberto. Comentários ao Código Civil: parte especial: do direito das obrigações (artigos 927 a 965), cit., p. 443.

${ }^{478}$ VENOSA, Silvio de Salvo. Direito civil: responsabilidade civil. 8. ed., cit., v. 4, p. 89.

${ }^{479}$ Id., loc. cit.

${ }^{480}$ RIZZARDO, Arnaldo. Responsabilidade civil, cit., p. 121.
} 
Sobreleva ressaltar, também, que o dispositivo focado consagra duas hipóteses distintas de responsabilização: a responsabilidade dos estabelecimentos pelos danos causados por seus empregados aos educandos e hóspedes e a responsabilidade por atos ilícitos cometidos por seus hóspedes ou educandos a terceiros. ${ }^{481}$

Deve-se enfatizar que a regra estatuída pelo artigo não alcança aqueles que são acolhidos graciosamente nesses estabelecimentos, porquanto, com muita propriedade e clareza, o preceito enunciado assinala a condição de se albergar mediante contraprestação financeira. ${ }^{482}$ Assim, para pleitear a reparação em caso de hospedagem gratuita, é necessária a comprovação de culpa dos proprietários de tais casas, não podendo ser aplicada a rigorosa regra da responsabilidade objetiva, nesses casos. ${ }^{483}$

Insta esclarecer que todos esses estabelecimentos são classificados como fornecedores de serviços e, nessa condição, se submetem à disciplina do art. 14, do Código de Defesa do Consumidor, que perfilhou a responsabilidade objetiva direta entre os fornecedores de serviços em relação aos danos causados aos hóspedes, educandos, etc. Assim, há quem entenda, inclusive, que a partir da vigência do mencionado estatuto, não é possível falar-se mais em responsabilidade civil por fato de outrem, ou seja, indireta, haja vista o fato de que a previsão pelo sistema consumerista é de responsabilidade civil direta, fundada no fato do serviço. ${ }^{484}$

Não obstante, necessário é separar as espécies de responsabilidades previstas no inciso em debate, para que possamos aplicar o regime jurídico adequado ao caso concreto, uma vez que nem sempre poderão ser utilizadas as regras contidas no estatuto consumerista aos prejuízos causados nesse cenário jurídico em discussão.

Como já houve referência, o dispositivo comentado, aparentemente, teria como escopo regular a responsabilidade civil pelos danos ocasionados aos hóspedes, por empregados do estabelecimento em que se encontram alojados ou pelos hóspedes, quando pratiquem atos lesivos a terceiros.

\footnotetext{
${ }^{481}$ DIREITO, Carlos Alberto Menezes; CAVALIERI FILHO, Sérgio. op. cit., p. 221.

${ }^{482}$ PEREIRA, Caio Mário da Silva. Instituições de direito civil. Contratos. Declaração unilateral de vontade. Responsabilidade civil, cit., v. 3, p. 392.

${ }^{483}$ RIZZARDO, Arnaldo. Responsabilidade civil, cit., p. 121. No entanto, recordamos a regra prevista no art. 392, do atual Código Civil, que trata dos contratos benéficos e dispõe que nesta espécie de negócio jurídico bilateral, responde por simples culpa o contratante a quem o contrato favorece e apenas por dolo aquele que não é favorecido.

${ }^{484}$ DIREITO, Carlos Alberto Menezes; CAVALIERI FILHO, Sérgio. op. cit., p. 222.
} 
Contudo, se ao dano ocorrido na esfera jurídica de direitos do hóspede aplica-se o Código de Defesa do Consumidor, caso o lesado esteja inserido em uma relação jurídica de consumo, esse estatuto jurídico não poderá, a priori, ser implementado na hipótese em que ocorra lesão a terceiro por conduta praticada diretamente por um hóspede, verbi gratia, que esteja hospedado no hotel, devendo, então, ser utilizado, nesse caso, o art. 932, IV, do Código Civil. ${ }^{485}$ É esse o sentido que nos parece ser o mais técnico.

Neste diapasão, e complementado o pensamento supracitado, a responsabilidade civil dos estabelecimentos que hospedam onerosamente as pessoas açambarcam as suas bagagens, em decorrência do art. 649 e seu parágrafo único do Código Civil, a menos que se prove que o dano adveio da ocorrência de caso fortuito ou força maior. ${ }^{486}$

Destarte, para os hóspedes e educandos que se valem da prestação de serviços oferecidos pelos estabelecimentos em discussão, serão aplicados os dispositivos que tratam do contrato de hospedagem, previsto no Código Civil, cumulado com o art. 14 do Código de Defesa do Consumidor que preconiza o seguinte: "o fornecedor de serviços responde, independentemente da existência de culpa, pela reparação dos danos causados aos consumidores por defeitos relativos à prestação de serviços"; aduzindo o parágrafo $1^{\circ}$ que: "o serviço é defeituoso quando não fornece a segurança que o consumidor dele pode esperar, levando-se em consideração as circunstâncias relevantes" dentre elas, de acordo com o inc. II," o resultado e os riscos que razoavelmente dele se esperam”.

No que tange aos educandos, vale a mesma regra, aqui esposada, com referência à aplicação do Código de Defesa do Consumidor para os eventuais danos que lhes forem causados, enquanto estejam usufruindo do serviço prestado pelo estabelecimento e, caso ocasionem prejuízos a terceiros, nas mesmas circunstâncias de tempo e lugar referidas, é de ser utilizada, pela vítima, o regramento contido no art. 932, IV, do Código Civil, para a busca da justa e devida indenização, em face do estabelecimento de ensino.

Entrementes, algumas complementações devem ser feitas, máxime no que diz respeito ao direito de regresso do estabelecimento de ensino, contra os pais do menor

\footnotetext{
${ }^{485}$ ARAÚJO, Paulo Dóron Rehder de. Responsabilidade objetiva com base na culpa. In: HIRONAKA, Giselda Maria Fernandes; SIMÃO, José Fernando (Coords.). Ensaios sobre a responsabilidade civil na pós-modernidade. Porto Alegre: Magister, 2009. v. 2, p. 365-366.

${ }^{486}$ RIZZARDO, Arnaldo. Responsabilidade civil, cit., p. 122.
} 
causador direto do dano, uma vez que a responsabilidade objetiva não afastaria o direito de regresso previsto no artigo 934, do atual Código Civil, nessa circunstância. ${ }^{487}$

É conveniente esclarecer que, de acordo com essa ótica, poderia o hospedeiro buscar o ressarcimento contra o menor causador do dano (art. 928) ou em face de seus genitores, situação que é muito freqüente na prática. Contudo, a linha de defesa dos pais, responsáveis diretos pelos atos dos filhos menores, nos termos do art. 932, I, do atual Código Civil, seria que o dever de guarda e vigilância fora transmitido, mesmo que temporariamente, ao estabelecimento de ensino, sendo este, por conseguinte, responsável pelas condutas lesivas perpetradas pelo menor, enquanto em seu poder. ${ }^{488}$

O estabelecimento de ensino é responsável pelo estudante, enquanto o mesmo se encontra em suas dependências, tanto no que tange à sua incolumidade física quanto por eventuais atos ilícitos que venha a praticar em detrimento de terceiros ou de outros alunos. Existe um dever básico de incolumidade e vigilância, inerente ao estabelecimento educacional que, hodiernamente, decorre dos preceitos do Código de Defesa do Consumidor que impõem a responsabilidade objetiva nesses casos. ${ }^{489}$

Sobreleva ressaltar que é esse o entendimento prevalecente, não obstante algumas ponderações terem sido feitas por alguns doutrinadores que advogam o seguinte: a escola, por exemplo, não pode ser responsabilizada por qualquer ato praticado pelo menor, desde que a sua conduta lesiva revele uma índole maléfica, fruto de deficiente formação moral. Isso, naturalmente, fugiria do controle do estabelecimento que não teria como obrigação imediata a formação do caráter do autor material do dano. ${ }^{490}$

Caso se trate de escola ou estabelecimento público, o regime jurídico a ser aplicado é o concernente ao art. $37, \S 6^{\circ}$, da $\mathrm{CF} / 88$, dispositivo que revela a responsabilidade objetiva da pessoa jurídica de direito público. ${ }^{491}$

Ainda que se trate de estabelecimento de ensino de curso de nível superior, a regra a ser aplicada, em qualquer das duas hipóteses, aqui enfrentadas e diferenciadas quanto ao

\footnotetext{
${ }^{487}$ RIZZARDO, Arnaldo. Responsabilidade civil, cit., p. 123.

${ }^{488}$ Id., loc. cit.

${ }^{489}$ VENOSA, Silvio de Salvo. Direito civil: responsabilidade civil. 8. ed., cit., v. 4, p. 91 . A despeito da clareza com que expõe o tema em debate não obstante, como referido, não concordamos com o mencionado autor quanto a abrangência do CDC, uma vez que com relação aos danos ocasionados por alunos a terceiros, a regra que preponderará é a do art. 932 aqui debatido.

${ }^{490}$ RIZZARDO, Arnaldo. Responsabilidade civil, cit., p. 123.

${ }^{491}$ GODOY, Cláudio Luiz Bueno de. op. cit., p. 776.
} 
regime jurídico, será a mesma. Vale dizer, quer seja o dano ocasionado ao universitário, ou na hipótese deste acarretar prejuízo na esfera de direitos de outrem, a resposta legal será a mesma. Ou seja, aplicar-se-á, no primeiro caso, o Código de Defesa do Consumidor e, na segunda hipótese, o art. 932, IV, do Código Civil, assegurando o direito de regresso da instituição de ensino, neste último caso, nos termos do art. 934 do mesmo diploma legal contra o estudante causador direto do dano. ${ }^{492}$

É de se consignar, por necessário, que a responsabilidade dos estabelecimentos, acima elencados, apenas será deflagrada, caso os autores materiais dos danos tenham agindo com elemento subjetivo, ou seja, com dolo ou culpa, nos mesmos termos dos incisos anteriormente explicitados.

$\mathrm{O}$ inciso $\mathrm{V}$, do art. 932, do $\mathrm{CC}$ estabelece a responsabilidade daqueles que gratuitamente houverem participado nos produtos do crime, até a concorrente quantia. É imperioso reconhecer que o mencionado inciso não se refere aos coautores dos crimes, porque, de acordo com o preconizado pelo art. 942 do atual diploma civil, "se a ofensa tiver mais de um autor, todos responderão solidariamente pela reparação."493

Aquele que participou gratuitamente no produto de um crime, resta evidente que está obrigado a restituí-lo até a concorrente quantia. ${ }^{494} \mathrm{O}$ dispositivo consagra o princípio do injusto enriquecimento, pois mesmo que não houvesse previsão expressa, as consequências previstas acerca da participação do produto do crime já eclodiriam por si só. ${ }^{495}$

Carlos Roberto Gonçalves afirma que a doutrina critica a manutenção do debatido inciso V, uma vez que fora alocado em dispositivo incompatível com sua essência. ${ }^{496}$

\footnotetext{
492“"Não há que se distinguir também, como entendemos, contrariamente à grande maioria da doutrina tradicional, que a responsabilidade dos estabelecimentos de ensino se debruce unicamente sobre pupilos menores. Essa posição dizia respeito ao passado. Não e feita essa distinção na lei e mesmo um estabelecimento de ensino de nível universitário, que abriga a maior parte de alunos maiores e capazes, submete-se à mesma diretriz... Desse modo, não há distinção ontológica entre um menor de 17 anos ou maior de 18 anos que agride e ocasiona danos a alguém que visita, transita ou se aproxima do estabelecimento de ensino do agressor, seja este de nível fundamental, médio ou de nível superior. Responderá sem dúvida pelos danos a pessoa jurídica que mantém a escola". VENOSA, Silvio de Salvo. Direito civil: responsabilidade civil. 8. ed., cit., v. 4, p. 94.

${ }^{493}$ DIREITO, Carlos Alberto Menezes; CAVALIERI FILHO, Sérgio. op. cit., p. 224.

${ }^{494}$ GONÇALVES, Carlos Roberto. Comentários ao Código Civil: parte especial: do direito das obrigações (artigos 927 a 965), cit., p. 456.

${ }^{495}$ VENOSA, Silvio de Salvo. Direito civil: responsabilidade civil. 8. ed., cit., v. 4, p. 94.

${ }^{496}$ GONÇALVES, Carlos Roberto. Comentários ao Código Civil: parte especial: do direito das obrigações (artigos 927 a 965), cit., p. 456.
} 
Desta forma, analisando todas essas situações, é possível inferir que na essência e na maioria dos casos (exceção ao art. 932, V, do atual Código Civil) a responsabilidade por fato de outrem depende da existência de relação jurídica, em que o causador do dano esteja sob a dependência, direção ou autoridade do eventual responsável pela indenização. É, ainda, relevante esclarecer que essas situações fáticas estão presentes na vida de pais e filhos capazes, desde que esses últimos sejam economicamente dependentes. Os genitores oferecem alojamento, dinheiro e educação, participando, ainda que indiretamente, do resultado danoso perpetrado pelos seus descendentes maiores.

Ademais, a interpretação dos dispositivos acima elencados tem se mostrado, muitas vezes, tão extensiva, em favorecimento da vítima de um dano que, é possível chegar-se à conclusão de que nem todos os requisitos constantes em cada um dos incisos devem estar realmente presentes, para o surgimento do dever de indenizar do civilmente responsável. Pense-se no vocábulo companhia, previsto no inciso I, do artigo 932, em discussão, e que, para muitos autores, acaba sendo dispensável para a eclosão da obrigação de indenizar do genitor não guardião em caso de pais separados.

Ora, se esse elemento (companhia) não é imprescindível, poder-se-ia afirmar, pela mesma razão que, caso estejam presentes a autoridade e companhia, nos moldes aqui tratados, a menoridade do filho seria passível de prescindibilidade para o surgimento do dever do seu genitor reparar um dano causado por aquele descendente capaz.

No caso dos pais, como referido, a essência da relação fática que eles possuem com os seus filhos, ainda que, absolutamente capazes, é muito semelhante com a acima narrada, nos incisos discutidos do art. 932 do atual Código Civil, haja vista o fato de que os filhos não trabalham e vivem sob a dependência econômica de seus genitores.

Diante desse cenário, o resultado prático que se extrai é a total submissão dos filhos para com seus pais, inclusive para a subsistência. São os genitores que oferecem ao menos o mínimo para a manutenção da vida de seus descendentes.

Assim, se assumem o encargo de cuidar devem também assumir o risco de se responsabilizar, uma vez que, como analisado no decorrer deste capítulo, o sistema incorpora a idéia de que o responsável por algo ou alguém indeniza caso ocorra eventos prejudiciais a terceiros, ocasionados pelo subordinado ou dependente. Essa dependência se traduz, ainda, na facilitação do prejuízo, uma vez que todas as situações vivenciadas pelos 
infratores derivam quase que, exclusivamente, de oportunidades surgidas de atos de seus responsáveis.

Com efeito, os responsáveis, nos casos de responsabilidade dos pais, indubitavelmente, como detentores do poder econômico no núcleo familiar possuem um grau de autoridade plena sobre os filhos, ainda que maiores de idade.

Ademais, nessa convivência prolongada, em que os filhos permanecem na casa de seus pais mesmo após a maioridade, ocorre a todo o momento a celebração de negócios jurídicos entre os genitores e seus descendentes, atos jurídicos que acabam incluindo-se na linha de desdobramento causal de eventuais ilícitos praticados pelos filhos absolutamente capazes.

Imagine-se o caso de doação, contrato unilateral, em que o pai doa a seu filho universitário, como presente pelo seu $18^{\circ}$ aniversário, um automóvel. Nesse mesmo dia o filho sai para uma festa e, dirigindo sob influência de álcool ou substância entorpecente, atropela e mata um arrimo de família que vendia pipocas na calçada. O jovem motorista, tomando-se esse exemplo, possuía como seu patrimônio apenas o carro que lhe fora doado por seu genitor. Nesse sentido pergunta-se: quem indenizará os familiares da vítima?

Os genitores, nessa condição, participaram da cadeia evolutiva do evento prejudicial, em questão, uma vez que celebraram contrato com o filho, ainda que conhecendo a personalidade difícil do jovem e sabendo da impossibilidade do mesmo de poder ressarcir eventual dano ocasionado a outrem porque não exerce atividade laborativa. Os pais precisam se preocupar, diante do cenário exposto, nesta dissertação, com as consequências jurídicas finais dos contratos que pactuam com seus filhos, devendo ser responsabilizados, nessas circunstâncias, pelo efeito danoso perante terceiros. A função social do contrato impõe essa obrigação, uma vez que os danos sociais ainda que individualmente suportados, provenientes desses atos jurídicos, não podem ficar irressarcidos.

O contrato deve ser ajustado com senso de responsabilidade dos contratantes, como já afirmado, para com a sociedade, que não deve suportar prejuízos em virtude da prática de atos jurídicos impensados. Os "valores plurais ou coletivos" devem se sobrepor ao individualismo exagerado daqueles que não se importam com os resultados advindos de suas condutas. É a tutela do "bem estar coletivo" expresso pela cláusula (princípio) da 
função social do contrato, em todos os seus desdobramentos, mormente no impacto que terá a citada avença perante o grupo social. ${ }^{497}$

Nesse sentido, é imperioso ressaltar que a autonomia da vontade é controlada pelo Estado, no que diz respeito à sua funcionalização e correspondência com os preceitos Constitucionais, ${ }^{498}$ não podendo ser considerada um valor em si mesma. ${ }^{499}$ Deveras, como será melhor tratado adiante, a função social do contrato, apesar de não eliminar a autonomia contratual, atenua ou reduz esse preceito quando presentes interesses da coletividade. ${ }^{500}$ Sobreleva ressaltar, contudo, que durante o liberalismo essa autonomia da vontade foi extremamente ampla. ${ }^{501}$

497، “O novo Código Civil, no seu todo, é um permanente aviso de advertência aos que intentam conspurcar o interesse social do direito, maculando, no particular, as relações contratuais pela quebra de paridade ou equivalência. Para que melhor se compreenda os contratos e espécie, regulados no novo Código Civil, como relações jurídicas obrigacionais, impende considerar, de imediato, acerca das cláusulas gerais dos contratos, acertadas pelos arts. 421 e 422, com emprego pertinente a todos eles. Tais disposições introdutórias articulam um direito contratual reestruturado ou reconstruído, pronto a servir ao princípio da socialidade, um dos pilares básicos do direito moderno. Esse princípio celebra a primazia ou preponderância dos chamados valores plurais ou coletivos em face dos equivalentes axiológicos do plano individual, em prestígio e tutela do bem-estar coletivo. Encontra-se ele na função social do contrato (art.421), na proteção ao hipossuficiente da relação contratual (art. 423), na natureza social da posse, a ditar reduções de prazo para a usucapião (arts. 1.238, parágrafo único, 1.239, 1.240,1.242, caput e parágrafo único) ou a permitir a expropriação judicial art. $1.228 \S 4^{\circ}$ ), como em outras disposições. Não é demais lembrar que essas regras vestibulares, pela aplicabilidade genérica de estipulação, empreendem e plasmam uma Nova Teoria Geral dos Contratos, suficientes a informar a relevância do trespasse do modelo clássico contratual, individualista e patrimonializante, para um modelo moderno de produção coletiva dos interesses contratados, a humanizar o direito contratual como fonte primária de interesse social. Bem a propósito, a conciliar os valores individuais e coletivos do contrato, no implexo de uma correlação inarredável, situa Miguel Reale ser o contrato "um elo que, de um lado, põe o valor do indivíduo como aquele que o cria, mas de outro lado, estabelece a sociedade como o lugar onde o contrato vai ser executado e onde vai receber uma razão de equilíbrio e medida" (in REALE, Miguel. O Projeto do Código Civil. São Paulo: Saraiva, 1986. p. 10). Por tal razão, prepondera o direito como função, segundo a análise funcional defendida por Noberto Bobbio. Impregnado, modernamente, pelos influxos axiológicos e sociológicos, e nutrido, ainda, pelas repercussões indeclináveis do econômico e do político, serve a sua funcionalidade a ditar uma nova concepção para a valorização do contrato enquanto "fenômeno de relação de condutas de intersubjetividade" e destinado como exemplo de concretitude do próprio direito. O contrato não é apenas um instrumento jurídico, de interesses puramente interpessoais ou de operação de proveitos. O seu conteúdo deve importar nos fins de justiça e de utilidade, em superação do egocentrismo individual onde permeiam a fragilização do débil e a dominação do mais forte". ALVES, Jones Figueirêdo. Código Civil comentado. Coordenadora Regina Beatriz Tavares da Silva. 6. ed. São Paulo: Saraiva, 2008. p. 376-377.

${ }^{498}$ Jorge Guillermo Portela, ao tratar do constitucionalismo e dos princípios jurídicos, disserta que “...un rasgo característico del constitucionalismo es la fijación, mediante normas constitucionales, de principios de justicia material destinados a informar a todo el ordenamiento jurídico". PORTELA, Jorge Guillermo. Los principios jurídicos y el neoconstitucionalismo, cit., p. 38.

${ }^{499}$ PERLINGIERI, Pietro. op. cit., p. 277.

${ }^{500}$ Neste sentido, ver jornada de direito civil, enunciado 23, que dispõe: “A função social do contrato, prevista no art. 421 do novo Código Civil, não elimina o princípio da autonomia contratual, mas atenua ou reduz o alcance desse princípio, quando presentes interesses metaindividuais ou interesse individual relativo à dignidade da pessoa humana”.

${ }^{501}$ ALVIM, Arruda. op. cit., p. 89. 
Deveras, não obstante a principiologia clássica dos contratos e, mais especificamente, o preceito da relatividade dos efeitos desses referidos pactos, é consentâneo com a evolução do direito, como inclusive assenta a teoria dos efeitos externos do contrato, o reconhecimento de que o debatido negócio jurídico pode eventualmente trazer consequências prejudiciais para terceiros influenciando, negativamente, a sua esfera de direitos. Não é, a nosso ver, juridicamente correta a omissão do sistema pátrio diante dessa circunstância, mormente em razão da ideologia dominante a respeito da necessidade de se indenizar prioritariamente a vítima de um evento lesivo.

Entrementes, não há harmonia entre os autores quanto aos princípios norteadores do fenômeno contratual. Ademais, não se pode olvidar que a evolução jurídica, nas últimas décadas, principalmente devido à alteração das referências valorativas, proporcionou uma releitura da principiologia básica dos contratos, ocasionando uma mudança em seu conteúdo. Além disso, foram incluídos, em nosso próprio sistema jurídico, outros preceitos igualmente relevantes, denominados por Paulo Luiz Netto Lobo de "princípios sociais dos contratos" ${ }^{, 502}$, que conferiram uma nova estrutura aos debatidos negócios jurídicos. Trata-se do princípio da boa-fé objetiva ${ }^{503}$ e da função social do contrato.

Demais disso, o princípio da relatividade dos contratos, em razão da cláusula (princípio) da função social do contrato, como será explicitado, não subsiste enrijecido como outrora. Vale dizer, a visão social desse negócio jurídico bilateral constitui relativização da idéia de que o contrato somente atinge as partes, não prejudicando e nem

\footnotetext{
502، Os princípios sociais do contrato não eliminam os princípios individuais do contrato, a saber, o princípio da autonomia privada (ou da liberdade contratual em seu tríplice aspecto, como liberdades de escolher o tipo contratual, de escolher o outro contratante e de escolher o conteúdo do contrato), o princípio de pacta sunt servanda (ou da obrigatoriedade gerada por manifestações de vontades livres, reconhecida e atribuída pelo direito) e o princípio da eficácia relativa apenas às partes do contrato (ou da relatividade subjetiva); mas limitaram, profundamente, seu alcance e seu conteúdo". Princípios Contratuais, in LÔBO, Paulo Luiz Netto e JÚNIOR, Eduardo Messias Gonçalves de Lyra (coordenadores). A Teria do Contrato e o Novo Código Civil, Recife: Ed. Nossa Livraria, 2003, p. 14.

${ }^{503}$ Para resumir todas as funções do princípio da boa-fé objetiva acima mencionadas, vale a pena trazer à baila os ensinamentos de Nelson Rosenvald para quem: "A boa-fé é multifuncional. Para fins didáticos, é interessante delimitar as três áreas de operatividade da boa-fé no Código Civil de 2002. Desempenha papel de paradigma interpretativo na teoria dos negócios jurídicos (art. 113); assume caráter de controle, impedindo o abuso do direito subjetivo, qualificando-o como ato ilícito (art. 187); finalmente, desempenha atribuição integrativa, pois dela emanam deveres que serão catalogados pela reiteração de precedentes jurisprudenciais (art. 422)". ROSENVALD, Nelson. Código Civil comentado. Coordenador Cezar Peluso. Barueri/SP: Manole, 2007. p. 315.
} 
beneficiando terceiros, posto que ressaltado tornou-se o espectro público do acordo de vontades entre os contratantes. ${ }^{504}$

Nesse diapasão, no que tange ao princípio da função social dos contratos ${ }^{505}$, que se encontra expressamente previsto no art. $421^{506}$ do atual Código Civil, é curial tentar esclarecer o seu significado que tem uma importância muito grande no sentido de fundamentação jurídica para as idéias aqui defendidas. Senão vejamos.

Como já tantas vezes nos referimos, todo direito subjetivo tem uma função social ${ }^{507}$ que, grosso modo, significa que o titular de uma prerrogativa jurídica não pode usá-la pura e simplesmente para trazer prejuízo alheio sem razão jurídica para tanto. O sistema, máxime em virtude do aduzido no artigo $187,,^{508}$ do Código Civil de 2002, não se compadece mais com o uso abusivo de um direito.

Muitos doutrinadores civilistas ${ }^{509}$ preconizam que a função social do contrato seria um corolário lógico do princípio da função social da propriedade, previsto expressamente em nossa Carta Maior, ${ }^{510}$ porquanto não haveria sentido nenhum em instituir apenas

\footnotetext{
${ }^{504}$ NERY JUNIOR, Nelson. Contratos no Código Civil, cit., p. 423.

${ }^{505}$ Fernando Noronha nos ensina que "todo direito tem uma função social, dispensando referência expressa". NORONHA, Fernando. Direito das obrigações: fundamentos do direito das obrigações e introdução à responsabilidade civil. São Paulo: Saraiva, 2003. v. 1, p.27.

${ }^{506}$ Jones Figueiredo Alves disserta que: "A "função social do contrato" acenta a diretriz de sociabilidade do direito", de que nos fala percucientemente, o eminente Prof. Miguel Reale, como princípio a ser observado pelo intérprete na aplicação dos contratos. Por identidade dialética guarda intimidade com o princípio da "função social da propriedade" previsto na Constituição Federal". ALVES, Jones Figueirêdo. op. cit., p. 376. Não obstante, impende destacar que, para Nelson Nery Júnior, a função social do contrato seria, em realidade, uma cláusula geral, assim como a boa fé objetiva. NERY JUNIOR, Nelson. Contratos no Código Civil, cit., p. 411. Neste mesmo sentido disserta o enunciado 22 da "Jornada de Direito Civil" nos seguintes termos: "A função social do contrato, prevista no art. 421 do novo Código civil, constitui cláusula geral, que reforça o princípio de conservação do contrato, assegurando trocas úteis e justas".

507، Tal como os direitos subjectivos, também os poderes de autonomia, efectivamente, não devem ser exercidos em oposição com a função social a que são destinados...” BETTI, Emilio. op. cit., t. 1, p. 334.

${ }^{508}$ Art. 187. Também comete ato ilícito o titular de um direito que, ao exercê-lo, excede manifestamente os limites impostos pelo seu fim econômico ou social, pela boa-fé ou pelos bons costumes.

${ }^{509}$ NERY JUNIOR, Nelson. Contratos no Código Civil, cit., p. 422.

${ }^{510}$ Art. $5^{\circ}$, XXIII, "a propriedade atenderá a sua função social”. Segundo a doutrina civilista, a função social da propriedade se expressa no fato de que a sua utilização deverá sempre observar, também, os interesses da coletividade. Representa, referido princípio, o modo de se operar a propriedade em prol da sociedade, não sendo lícito, perante o ordenamento jurídico pátrio, a sua utilização egoísta. É curial esclarecer que a implementação desta norma jurídica limita o direito de propriedade em benefício do corpo social. De acordo com Fábio Ulhoa Coelho: "Garantido o cumprimento da função individual, deve o uso da propriedade compatibilizar-se com os demais interesses que gravitam em torno dela. Ao determinar que a propriedade cumpra também sua função social, a Constituição prestigia os interesses dos não proprietários que podem ser afetados pelo exercício do direito de propriedade (Silva, 1976: 254/256). Desse modo, o dono do imóvel no qual existe uma floresta cuja preservação interessa à sociedade pode ter o exercício do seu direito limitado (pela função social), desde que continue contando com o bem como alternativa de sustento (função individual). Desse modo, a Constituição, ao proteger a propriedade privada e determinar
} 
função social a algo que representa o maior valor patrimonial compartilhado pela sociedade e prescindir do mesmo regime jurídico o instrumento utilizado para a sua aquisição. Se a propriedade deve ter função social, o contrato, igualmente, deve possuir esse mesmo valor para a harmonia e equilíbrio do sistema, pois representa esse negócio jurídico bilateral o segmento dinâmico da atividade econômica. ${ }^{511}$

De acordo com Humberto Theodoro Jr., ${ }^{512}$ o princípio da função social dos contratos possuiria dois níveis, quais sejam, os denominados intrínseco e o extrínseco. $\mathrm{O}$ primeiro manifestar-se-ia na relação interna das partes, originada com a celebração do contrato, materializando-se mais precisamente no preceito da boa-fé objetiva, exigindo dos contratantes um padrão de comportamento leal e honesto entre si. Já o segundo nível, que é o que mais nos interessa, revela-se por meio do impacto eficacial do contrato perante o grupo social. Seria a visão do contrato em face da coletividade.

O contrato deve constituir, no nível extrínseco da função social, um instrumento que perfaça o desenvolvimento da sociedade, não podendo ser, por conseguinte, utilizado para causar o seu prejuízo. Então, esse negócio jurídico, em debate, deve ser não somente um instrumento de circulação de riquezas entre os contratantes, individualmente considerados, mas também uma forma de possibilitar o progresso social. As partes de um contrato devem observar sempre o bem comum e as consequências que a celebração desse negócio jurídico trará ao seio social.

Para Nelson Nery Júnior, a função social do contrato é uma cláusula geral e, como tal, exige do operador do Direito o seu preenchimento com valores, ou seja, o conteúdo dessa figura jurídica, assim como todas as outras cláusulas gerais, dependerá da atividade do intérprete ao preenchê-la. Trata-se, mais precisamente, de enunciação abstrata da lei sem que, ao mesmo tempo, esta última forneça a consequência jurídica de sua utilização que fica a cargo do aplicador dela, diferentemente do que ocorre, verbi gratia, com os

que seu uso atenda à função social, prescreveu: de um lado, não se podem sacrificar os interesses público, coletivo e difuso para atendimento do interesse do proprietário; mas também não se pode aniquilar este último em função daqueles. A propriedade, em suma, deve estar apta a cumprir simultaneamente as funções individual e social que dela se espera”. COELHO, Fábio Ulhoa. Curso de direito civil. São Paulo: Saraiva, 2006. v. 4, p. 58-59.

511 "Naturalmente, porém, a necessidade de negócios entre um indivíduo e outro, só se vê claramente naqueles ordenamentos econômico-sociais que reconhecem aos indivíduos um conjunto de bens que lhes competem, isto é, nos ordenamentos baseados no reconhecimento da propriedade individual. Efetivamente, só com base nesse reconhecimento, a circulação dos bens, assim como a prestação de serviços entre os indivíduos, são entregues, necessariamente, à autonomia privada”. BETTI, Emilio. op. cit., t. 1, p. 93.

${ }^{512}$ THEODORO JÚNIOR, Humberto. O contrato e sua função social. Rio de Janeiro: Forense, 2003. p.43. 
conceitos legais indeterminados que apresentam, apesar de sua vagueza, o resultado jurídico de sua implementação. ${ }^{513}$

A função social do contrato, nesse sentido, exige o emprego por parte do hermeneuta de valores jurídicos, morais, sociais e econômicos para ser adequadamente interpretada. O Juiz decidirá de acordo com o que lhe for apresentado no caso concreto, não havendo prevista uma solução legal. O papel de criação do juiz, dessa forma, é bem mais extenso, sendo múltiplas as soluções possíveis para o julgador ao se deparar com a cláusula geral da função social do contrato, podendo até determinar indenização da parte que não a observou. ${ }^{514}$

A cláusula geral possibilita um intercâmbio entre o sistema legal e outros sistemas sociais. Permite a introdução no ordenamento jurídico de conceitos referentes à informática, a economia, a bioética, e de muitas outras ciências. A sua concretização permite a entrada no sistema civil dos princípios constitucionais expressos e implícitos que serão, dessa forma, utilizados para a extração da norma jurídica adequada ao caso concreto. $^{515}$

Essa assertiva é de extrema relevância, porquanto toda a principiologia constitucional que fundamenta a responsabilidade civil, deve ser empregada no momento da interpretação da cláusula geral referente à função social do contrato, em razão de sua ínsita abertura, o que possibilitará resultados jurídicos mais compatíveis com a necessária indenização da vítima.

Com efeito, é, nesse momento, que se torna juridicamente adequada a utilização dos princípios da dignidade da pessoa humana, do solidarismo e da isonomia que devem ser aplicados na cláusula geral da função social do contrato para a concretização do direito. Não se relegue ao olvido o pensamento de Ricardo Lorenzetti de que a decisão judicial representa mais um ato de criação normativa do que de mera aplicação do texto legal. ${ }^{516}$

\footnotetext{
${ }^{513}$ NERY JUNIOR, Nelson. Contratos no Código Civil, cit., p. 412. Para Ricardo Lorenzetti: "La cláusula general es una norma de sentido general, no específico, cuyo contenido debe ser precisado por el Juez, según la evolución de la conciencia social”. In LORENZETTI, Ricardo. La discrecionalidad del juez em el marco de la legislación, cit., p. 159.

${ }^{514}$ NERY JUNIOR, Nelson. Contratos no Código Civil, cit., p. 416-417; AGUIAR JÚNIOR, Ruy Rosado de. Projeto do Código Civil: as obrigações e os contratos. Revista dos Tribunais, São Paulo, ano 89, v. 775, p. 20, maio 2000.

${ }^{515}$ LORENZETTI, Ricardo. La discrecionalidad del juez em el marco de la legislación, cit., p. 161-164.

${ }^{516}$ Id. Ibid., p. 162.
} 
Impende reconhecer, ainda, que, uma vez que essa cláusula geral, por expressa previsão legal (art. 2.035, parágrafo único) é norma de ordem pública, pode o juiz aplicá-la de ofício, não estando sujeita a preclusão, sem ferir o princípio processual da congruência entre a sentença e o pedido, conquanto esse preceito deva incidir somente nas questões dispositivas. Ademais, essa cláusula geral de função social do contrato permite que o juiz, em razão da abstração que lhe é peculiar, crie a lei entre as partes contratantes. ${ }^{517}$

A partir da utilização da cláusula geral há o abandono do princípio da tipicidade o que reforça, consequentemente, o poder de revisão do Magistrado, fato este que exige uma magistratura mais preparada para o exercício de sua função e melhor conhecedora dos costumes e usos locais. ${ }^{518}$

O contrato não é mera relação individual. Deve-se atentar para os seus efeitos econômicos, sociais, ambientais e porque não dizer culturais. Vale dizer, salvaguardar esse negócio jurídico bilateral apenas para garantir a eqüidade das relações negociais não se aproxima nada da idéia de função social. O contrato possuirá uma função social - uma função pela sociedade - somente quando for dever dos celebrantes da avença atentar para as necessidades do bem comum, para o bem de toda a coletividade. Acima da necessidade de que o acordado seja de fato respeitado, acima do interesse em que a manifestação de vontade seja precisamente adimplida e acima da ideia de equilíbrio contratual, é necessário que o contrato seja benéfico para a sociedade, ou, ao menos que não seja a causa de prejuízos à coletividade, o que significa dizer que o contrato deve ser justo do ponto de vista social. $^{519}$

Obedecendo ao que já preconizava de há muito o art. $5^{\circ}$ da Lei de Introdução ao Código Civil, a função social do contrato tem como escopo a conjugação do bem comum das partes celebrantes da avença e da coletividade. Dessa forma, pode-se referir a uma função social interna e uma função social externa do contrato. ${ }^{520}$

Assim, se o contrato deve também resguardar interesse do grupo social, a celebração de avenças precisa vir cercada de responsabilidade para com a sociedade, uma vez que o simples interesse individual dos contratantes não é o único bem jurídico tutelado

\footnotetext{
${ }^{517}$ NERY JUNIOR, Nelson. Contratos no Código Civil, cit., p. 420.

${ }^{518}$ AGUIAR JÚNIOR, Ruy Rosado de. op. cit., p. 20.

${ }^{519}$ SANTOS, Eduardo Sens. O novo Código Civil e as cláusulas gerais: exame da função social do contrato. Revista Brasileira de Direito Privado, São Paulo, n. 10, abr.jun. 2002. p. 29.

${ }^{520}$ ROSENVALD, Nelson. op. cit., p. 312.
} 
em questão. Há outros bens que necessitam de igual proteção por parte do Estado em razão do princípio da função social do contrato.

Essa função consiste no reconhecimento de que os contratantes não podem, em determinadas circunstâncias, estabelecer uma contratação desenfreada, uma vez que determinadas avenças estabelecidas entre as pessoas podem, seguramente, causar danos à coletividade. $^{521}$

A teoria dos efeitos externos dos contratos já sinaliza a possibilidade de um terceiro pleitear, em ação própria, indenização a dois contratantes que estipularam uma determinada avença e que, posteriormente, vislumbra-se que os efeitos desse contrato inseriram-se na linha de desdobramento natural de um prejuízo sofrido por aquela pessoa alheia à convenção. ${ }^{522}$

A teoria dos efeitos externos dos contratos tem como objeto a interferência contratual, no mundo alheio à vinculação da avença e a influência do mundo exterior no acordado entre os contratantes. Vale dizer, a referida teoria cuida de duas espécies de situações que se relacionam com o contrato, quais sejam, a obrigatoriedade de terceiros respeitarem o acordado entre as partes, de modo a não prejudicar o seu natural desenvolvimento e a eventualidade do contrato prejudicar a esfera jurídica de direitos alheios ao estabelecido contratualmente. ${ }^{523}$

O caso que mais nos interessa é o referente à segunda hipótese em que terceiros adquirem, perante os contratantes, o direito de lhes pleitearem indenização quer por convenção (estipulação em favor de terceiros); por imperativo legal, como é o caso preconizado nos artigos 12 e 14 do Código de Defesa do Consumidor e, finalmente, em virtude de ato contratual ilícito causador de prejuízo. Nessa última circunstância o contrato, estabelecido entre duas ou mais pessoas, acaba ocasionando lesão a uma outra pessoa e

\footnotetext{
${ }^{521}$ ALVIM, Arruda. op. cit., p. 90.

522،"Uma situação que se citou na abordagem do direito francês bem pode ilustrar essa afirmação. Foi admitido a um locatário que sofre com problemas no prédio alugado agir contra o arquiteto que executou mal suas obrigações, mesmo sendo terceiro em relação ao contrato celebrado entre esse último e o proprietário do imóvel locado". THEODORO NETTO, Humberto. Efeitos externos do contrato: direitos e obrigações na relação entre contratantes e terceiros. Rio de Janeiro: Forense, 2007. p. 210.

${ }^{523}$ THEODORO NETTO, Humberto. op. cit., p. 169-171.
} 
esta, por via de conseqüência, ingressa com uma ação judicial requerendo ressarcimento e utiliza, como causa de pedir, o mencionado negócio jurídico bilateral alheio. ${ }^{524}$

Deveras, novidade nenhuma diante de nosso sistema jurídico está se defendendo. De fato, o nosso ordenamento jurídico, mais precisamente, o Código de Defesa do Consumidor assume essa postura protecionista inclusive para aquele que não participou do contrato de consumo, ou seja, trata-se do denominado bystander que, de acordo com o art. 18 do referido diploma, possui ação contra os fornecedores do produto ou do serviço, quando tenha sido lesionado por produto ou serviço adquirido por outra pessoa. Trata-se, a nosso ver, da aplicação da teoria dos efeitos externos do contrato.

Nesse caso, a vítima é um terceiro que, prejudicado por contrato celebrado por outras pessoas, terá direito de buscar a indenização perante a parte presumidamente mais forte da relação jurídica consumerista, qual seja, o fornecedor. Destarte, na essência tem-se a presença de direito à indenização de uma pessoa em virtude das consequências lesivas de um negócio jurídico bilateral praticado por terceiros.

Não são outras as palavras de Nelson Rosenvald:

"Sem dúvida, não é raro que um terceiro seja atingido por um contrato que, em princípio lhe seja completamente estranho. Seria o caso daquele que é vítima de um acidente de consumo, derivado de relação em que não participara como consumidor stricto sensu (art. $2^{\circ}$ do CDC). De acordo com o artigo 18 do Código de Defesa do Consumidor, o bystander possui ação de responsabilidade objetiva contra os fornecedores do produto ou serviço defeituoso, na qualidade de consumidor equiparado". ${ }^{525}$

Assim, não seria exagero exigir dos pais, uma vez que titularizam a condição de parte economicamente forte da relação contratual em debate, a indenização à vitima em razão de ato lesivo praticado pelos filhos, desde que presentes todos os requisitos aventados no texto.

\footnotetext{
524، A doutrina e a jurisprudência francesa admitem largamente a eficácia externa dos contratos. As divergências situam-se me termos conceituais, quanto aos critérios de classificação das duas categorias, de partes e de terceiros, e quanto à nomenclatura utilizada. Há, porém, consenso quanto à oponibilidade dos contratos, como uma propriedade das convenções de caráter geral. Dessa oponibilidade faz a doutrina derivar o reconhecimento de que o terceiro pode se valer de um contrato para tirar proveito numa situação específica, responsabilizando contratual ou aquilianamente um dos contratantes; ou pode ser compelido a determinada conduta (omissiva ou comissiva) em tutela de integridade do contrato ou em reparação da lesão de crédito gerada pela intromissão indevida na relação inter partes, com base na sua responsabilidade delitual. THEODORO NETTO, Humberto. op. cit., p. 138-171.

${ }^{525}$ ROSENVALD, Nelson. op. cit., p. 313.
} 
Demais disso, o art. 187 preconiza que comete ato ilícito o titular de um direito que, ao exercê-lo o faz em detrimento da sua função social. Antonio Soares Levada, em seu livro a respeito do abuso de direito, citando Josserand, assevera que:

"Para o consagrado mestre francês, existe abuso do direito quando o ato é exercido de acordo com o direito da pessoa e contrariamente à regras sociais; desse modo os pretensos direitos subjetivos não passam de direitos funções, que têm finalidade a cumprir e dela não se pode desviar, sob pena de cometimento de um abuso do direito., ${ }^{, 526}$

Ora, ao exercer a liberdade de contratar com os filhos, os pais agem de acordo com o direito que lhes é imanente. Contudo, os genitores devem projetar as possíveis consequências prejudiciais desse negócio jurídico em face da sociedade, deixando, inclusive, de celebrar negócios jurídicos com seus filhos, principalmente quando saibam, antecipadamente, que qualquer ato ilícito praticado pelo seu filho, nas condições aqui tratadas, ressentirá, a priori, de uma possível resposta indenizatória, já que não possui o seu descendente idôneo patrimônio para isso. Ou seja, os pais devem prever o impacto que esses contratos terão perante o corpo social e deixar, eventualmente de praticá-los em benefício da comunidade.

Assim, prevendo todas essas vicissitudes, os pais devem tomar as precauções necessárias para evitar a ocorrência de atos lesivos e colocar, por conseguinte, o seu patrimônio à disposição da vítima caso seja necessário.

De toda sorte, há aqueles autores que entendem ser a função social do contrato não somente uma cláusula geral, mas também um princípio contratual, com toda força normativa. $^{527}$ Em razão disso, não se pode refutar a sua imediata aplicação, sendo necessário reconhecer, ainda, a sua natureza de fundamento não só da ordem econômica,

\footnotetext{
${ }^{526}$ LEVADA, Carlos Antonio Soares. O abuso e o novo direito civil brasileiro. São Paulo: Revista Unianchieta, 2007.

${ }^{527}$ MELLO, Celso Antonio Bandeira. op. cit., p. 841-842. Para Ricardo Luis Lorenzetti os princípios, “em sua longa história, têm revelado duas virtudes que lhes deram força. A primeira é a sua simplicidade, ou ao menos a aspiração de ter um conjunto de idéias que orientam um cálculo jurídico. A segunda é sua hierarquia superior. Qualquer que seja a concepção que se desenvolva acerca deles, têm sido sempre situados bem alto; para alguns integram o Direito natural, para outros têm uma raiz histórica; para outra opinião são interiores ao ordenamento, mas são obtidos por generalização de normas e são superiores a elas. Esta altura, esta superioridade é que permite conferir-lhes uma função de controle, de limite, de guia da atividade infraprincipal". LORENZETTI, Ricardo. Fundamentos do direito privado, cit., p. 313.
} 
como dos objetivos constitucionais (art. $1^{\circ}$, III, e $3^{\circ}$, I, da CF) de valorização do ser humano quando considerado potencial parte contratante. ${ }^{528}$

Os princípios retratam a idéia de que não lhe são reservados pelo sistema jurídico apenas uma finalidade integrativo-hermenêutico, ${ }^{529}$ porquanto enunciam valores fundantes, devendo os aplicadores da lei tratá-los como normas jurídicas aptas a irradiar efeitos vinculantes. ${ }^{530}$

No que tange ao fato da função social do contrato ser uma cláusula geral, impende considerar que essa circunstância dota o contrato de maior mobilidade contextual, pois permite a entrada de valores sociais no momento de sua interpretação, além de admitir a atualização automática de seus enunciados a partir da evolução do pensamento social. ${ }^{531}$

Não se pode negar, como exaustivamente reiterado, o poder e o controle que os pais possuem sobre as atividades de seus filhos, ainda que absolutamente capazes para os atos da vida civil, por ocasião destes últimos serem dependentes economicamente dos primeiros. Assim, o mesmo poder de direção e controle que os progenitores têm sobre os seus filhos inimputáveis, na prática se revela da mesma forma em relação a esses descendentes maiores, desde que vivam sob a sua dependência econômica.

Interessante notar o disposto no artigo 1113 do Código Civil argentino que, caso estivesse presente em nossa codificação civil, possibilitaria com mais tranqüilidade a implementação da ideia por nós aqui defendida acerca da responsabilidade dos pais por atos de seus filhos maiores desde que dependentes. Vale dizer, o mencionado dispositivo legal, ao tratar da responsabilidade civil indireta, aduz que a obrigação de indenizar de uma pessoa se estende aos casos em que um terceiro que esteja sob sua dependência ocasione prejuízo outrem. ${ }^{532}$

\footnotetext{
${ }^{528}$ GODOY, Cláudio Luiz Bueno de. Função social do contrato: os novos princípios contratuais. São Paulo: Saraiva, 2004. p. 101-109. (Coleção Agostinho Alvim. Coordenação Renan Lotufo).

${ }_{529}^{5}$ Id. Ibid., p. 101.

530،....os princípios são normas, mas de um tipo especial. Têm uma estrutura deontológica, já que expressam um dever ser, mas são distintos das regras porque estas podem ser cumpridas ou descumpridas de um modo claro. O princípio, por sua vez, ordena que algo seja cumprido da melhor medida possível; é uma busca do ótimo". LORENZETTI, Ricardo. Fundamentos do direito privado, cit., p. 317.

${ }^{531}$ FARO, Frederico Kastrup. Boa-fé objetiva e dever de cooperação: uma análise sob as óticas do exercício da autonomia privada e da execução do contrato, cit., p. 6-7.

${ }^{532}$ In verbis o artigo 1.113, do Código Civil argentino, dispõe que: "La obligación del que ha causado un daño se extiende a los daños que causaren los que están bajo su dependencia, o por las cosas de que se sirve, o que tiene a su cuidado. (Párrafo agregado por Ley 17.711)En los supuestos de daños causados con las cosas, el dueño o guardián, para eximirse de responsabilidad, deberá demostrar que de su parte no hubo
} 
Entretanto, impende destacar que o referido artigo, de acordo com a jurisprudência pesquisada, encontra correspondência interpretativa no art. 932, III, do nosso atual diploma civil, porquanto trata da responsabilidade civil dos empregadores pelos atos de seus empregados. 533

Não obstante, considerando que as manifestações da atividade humana possuem um potencial lesivo, depreende-se que, se alguém estiver na cadeia evolutiva da atividade danosa de algum dependente seu, pode, eventualmente, dependendo da situação jurídica em que esteja inserido, ser também responsável pelo prejuízo.

Realmente, de acordo com os dispositivos estudados ao longo do capítulo atinente à responsabilidade civil indireta e sua estrutura, pudemos verificar, também, que o fundamento da eclosão de indenizar a lesão não se encontra apenas no risco, mas também no dano. Exemplo mais emblemático dessa fundamentação complexa, formada pelo perigo e prejuízo para o surgimento da obrigação de ressarcir, vislumbra-se na responsabilidade objetiva do tutor e do curador pelos atos do tutelado e curatelado. Não é possível, nesses casos, falar-se em criação de risco, posto que os tutores e curadores, contrariamente, desenvolvem uma atividade socialmente útil. Inobstante, o Código Civil atribui-lhes responsabilidade objetiva, por expressa previsão legal, como consequência do fardo social que desempenham, não com o escopo de penalizar a criação ou aumento de um risco, mas

culpa; pero si el daño hubiere sido causado por el riesgo o vicio de la cosa, sólo se eximirá total o parcialmente de responsabilidad acreditando la culpa de la víctima o de un tercero por quien no debe responder. Si la cosa hubiese sido usada contra la voluntad expresa o presunta del dueño o guardián, no será responsable".

533،"Requiere el artículo 1.113 1er. párrafo del Código Civil que exista, al momento de causarse un daño, una determinada relación entre el responsable indirecto y el agente del daño, que justifique el nacimiento de la obligación resarcitoria de aquél. El Código Civil no dice que se deba responder por el hecho de los dependientes, sino que expresa que el principal debe responder por el hecho de las personas que están bajo su dependencia, lo que no implica necesariamente una subordinación permanente, sino que abarca también la sujeción ocasional, temporaria o parcial para uno o varios asuntos determinados. Es que el vínculo de subordinación es solo una condición puramente objetiva para atribuir o propagar la responsabilidad desde el agente autor material del daño, hacia el principal responsable, pudiéndose extender dicho vínculo a situaciones en que el agente directo del daño goza de una mayor independencia y autonomía en el ejercicio de su cometido.-Referencia Normativa: Cci Art. 1113" (Cc0001 Mo 51327 Rsd-274-5 S-Fecha: 17/11/2005-Juez: Luduena (sd)-Carátula: Gerschman Nancy Noemí C/ Confederación Evangélica Bautista Y Otros S/ Daños Y Perjuicios-Mag. Votantes: Ludueña - Castellanos Russo-LDT). NOTÍCIAS MAGISNEUQUEN.

Disponível em: $<$ http://magisneuquen.org/index.php?option=com_content $\&$ view=article\&id=367:jurisprudencia\&catid=59 :civil\&Itemid=132\#, pesquisa efetuada no dia 9/08/2010, às 9:12 hrs > . 
com a finalidade exclusiva de proporcionar o devido ressarcimento a quem é prejudicado por ato de alguém que recebe do sistema jurídico uma proteção especial. ${ }^{534}$

E não se relegue ao olvido, outrossim, o fato de que a maioridade, por si só, não tem o condão de afastar algumas benesses jurídicas destinadas ao jovem, mesmo depois de completar 18 anos. Os seus genitores, por expressa disposição sumular ${ }^{535}$, têm o dever automático de continuar arcando com os encargos alimentares de seus filhos mesmo após a aquisição da plena capacidade, de forma que a independência e liberdade almejadas pelo legislador aos jovens adultos se mostram incompatíveis com a realidade fática.

Assim, se há dependência e, por conseguinte, proteção especial destinada aos filhos, nas circunstâncias aqui narradas, além da imperiosa necessidade de se indenizar sempre a vítima de um ato lesivo, impende reconhecer que o sistema favorece a construção da responsabilidade civil dos pais pelos atos dos filhos maiores que vivem sob sua dependência econômica.

Como tratado, a prática contratual entre genitor e filho, sem que este último possua capacidade financeira para indenizar eventuais danos perpetrados na esfera jurídica de direitos de outrem, também traz, em virtude da função social do contrato e da teoria dos efeitos externos do contrato, a viabilidade de se responsabilizar os pais nas específicas circunstâncias aqui aludidas.

\footnotetext{
${ }^{534}$ SHREIBER, Anderson. op. cit., p. 29-30.

${ }^{535}$ Súmula 358 do STJ. "O cancelamento de pensão alimentícia de filho que atingiu a maioridade está sujeito à decisão judicial, mediante contraditório, ainda que nos próprios autos".
} 


\section{TEORIAS SOBRE O NEXO DE CAUSALIDADE}

Requisito imprescindível para o surgimento da obrigação de indenizar é a ocorrência de dano, considerado como o fato produtor de lesões a interesses juridicamente protegidos de outrem, tanto os de caráter patrimonial como os de natureza não patrimonial. A conduta humana e o nexo de causalidade também são outros componentes necessários para a eclosão da responsabilidade civil. ${ }^{536}$

Assim, no escólio de Maria Helena Diniz, a conduta, um dos elementos imprescindíveis da responsabilidade civil é "Ato humano, comissivo ou omissivo, ilícito ou lícito, voluntário e objetivamente imputável, do próprio agente ou de terceiro, ou fato de animal ou coisa inanimada, que cause dano a outrem, gerando o dever de satisfazer os direitos do lesado".537

Dessa forma, entre o dano e o seu suposto causador deve haver uma relação de causa e efeito, também denominada de nexo causal. É curial esclarecer que é possível, nesse sentido, que haja ato ilícito e dano, sem que um seja considerado a causa do outro. Se o dano for provocado por agente externo ou se for ele consequiência de culpa exclusiva da vítima restará excluída a causalidade. ${ }^{538}$

Explicitados os fundamentos que formam o alicerce da estrutura dos primeiros elementos necessários à caracterização da responsabilidade civil, resta-nos a análise do nexo de causalidade que completa o trinômio de sua potencialização e que, indubitavelmente, traz muita celeuma na doutrina e jurisprudência. Ademais, como dizia Agostinho Alvim, o tema atinente ao nexo de causalidade é capital para a matéria de responsabilidade civil. ${ }^{539}$

\footnotetext{
536، A importância do estudo do nexo causal tem avultado, nestes últimos tempos, uma vez que a teoria do risco prescinde da culpa, para fundamento da responsabilidade, e só lhe bastam o dano e o nexo causal". ALVIM, Agostinho. op. cit., p. 342.

${ }^{537}$ DINIZ, Maria Helena. Curso de direito civil brasileiro. 12. ed. aum. atual. São Paulo: Saraiva, 1998. v. 7 , p. 37.

${ }^{538}$ RODRIGUES, Silvio. Direito civil: parte geral, cit., v. 1, p. 302. Nas lições de Roberto Senise Lisboa: “A inexistência de prejuízo econômico e moral impede a imputação do dever de indenizar. De igual modo, não se pode responsabilizar determinada pessoa por um dano sofrido pela vítima quando, apesar da existência de prejuízo e de sua comprovação, não se lograr êxito em se estabelecer a relação entre a conduta perpetrada ou patrocinada pelos suposto agente a esse mesmo prejuízo." LISBOA, Roberto Senise. Manual de direito civil: obrigações e responsabilidade civil, cit., v. 2, p. 516.

${ }^{539}$ ALVIM, Agostinho. op. cit., p. 342.
} 
Nexo de causalidade é a relação de causa e efeito entre a conduta potencialmente eficaz para modificar o mundo exterior e a sua consequente alteração. É o vínculo idôneo que liga o dano a um evento.

Não se pode esquecer, também, de que o nexo de causalidade não se confunde com a imputabilidade. É possível que esta última exista, sem que se possa falar no liame causal; o vínculo de causalidade é objetivamente aferido. Trata-se de uma questão de fato (quaestio facti). Por outro lado, a imputabilidade é elemento subjetivo, uma vez que se refere a atributos da pessoa ainda que sejam analisados de maneira objetiva. ${ }^{540}$

Essa noção de nexo de causalidade estava presente no direito romano. A Lei Aquília era bem rigorosa, porque sempre impunha que a lesão ocorresse corpore corpori, pelo corpo do autor do dano e sobre o corpo do ofendido. Assim, o prejuízo deveria ser o resultado direto do ato exteriorizado do ofensor. ${ }^{541}$

É importante ressaltar que o Direito Penal contribuiu substancialmente para a sistematização desse inexorável requisito da responsabilidade civil, dando-lhe contornos mais científicos e precisos. ${ }^{542}$

Por vezes, a fixação do nexo de causalidade não traz grandes dificuldades para a sua identificação, sendo considerada de solução imediata e singela. Todavia, em algumas circunstâncias, a demonstração de sua existência pode tornar-se complexa, trazendo incertezas e obscuridades que influenciarão na própria imputação da responsabilidade. ${ }^{543}$ Daí decorre a dificuldade em se estudar a teoria do nexo causal, mormente em razão do frequente surgimento de concausas que auxiliam, não rara vez, na eclosão do resultado danoso. ${ }^{544}$

\footnotetext{
${ }^{540}$ LISBOA, Roberto Senise. Manual de direito civil: obrigações e responsabilidade civil, cit., v. 2, p. 517.

${ }^{54}$ LOPES, Miguel de Serpa. Curso de direito civil: fontes acontratuais das obrigações. Responsabilidade civil. 4. ed. Rio de Janeiro: Freitas Bastos, 1995. p. 218. (Biblioteca Jurídica Freitas Bastos, v. 5). Cristán Aedo Barrena, ao tratar dos requisitos da lex Aquilia, assevera que: "En cuanto a la relación de causalidad, lo primero que debe decirse es que la lex Aquilia no señalaba cuando un evento debía considerarse consecuencia de un cierto comportamiento. La interpretación de los verbos, de outra parte, permitía concluir que la conducta debía ser considerada causa directa del resultado. Tambíen resulta obvio que los juristas romanos no se dedicaron al tratamiento dogmático del tema causal, ni siquiera lo abordaron especialmente, sino que, por el contrario, las cuestiones causales son desarrolladas en el contexto de la interpretación operativa de las palabras contenidas en los capítulos primero y tercero...” AEDO BARRENA, Cristián. op. cit., p. 319.

${ }^{542}$ LEMOS, Patrícia Faga Iglecias. Meio ambiente e responsabilidade civil do proprietário (análise do nexo causal). São Paulo: Ed. Revista dos Tribunais, 2008. p. 130.

${ }^{543}$ BRUNO, Aníbal. Direito penal: parte geral. Rio de Janeiro: Forense, 1978. t. 1, p. 320-321.

${ }^{544}$ ALVIM, Agostinho. op. cit., p. 343.
} 
Deveras, se para qualquer acontecimento a ação ou omissão fosse a sua única e exclusiva causa, o problema de investigação do nexo de causalidade não surgiria. Entrementes, a discussão nasce da complexidade dos antecedentes causais do evento, haja vista a circunstância de que a conduta comissiva ou omissiva traz, em sua realidade fática, uma série encadeada de acontecimentos relevantes. ${ }^{545}$

Diferenciam-se, na doutrina, as concausas sucessivas das concausas simultâneas. Com relação a estas últimas, há apenas um dano que, no entanto, foi ocasionado por mais de uma causa. Configura-se no caso em que uma lesão pode ser atribuída a muitas pessoas, sendo que a reposta dada pelo ordenamento jurídico, nesse caso, é estabelecer a responsabilidade solidárias, entre os autores do fato danoso, nos termos do art. 942 do atual Código Civil. ${ }^{546}$

A complexidade surge, não obstante, em relação às concausas sucessivas, em que há uma cadeia de causas e efeitos, uma vez que difícil será precisar qual foi a causa realmente responsável para o resultado lesivo. ${ }^{547}$

Não obstante a sua extrema importância para a responsabilização criminal e civil, apenas tardiamente a doutrina penalista teve seus estudos iniciados com mais profundidade e ocupou-se mais detidamente do tema. ${ }^{548}$

Muitas são as teorias sobre o nexo causal. Não obstante, dar-se-á especial ênfase, neste momento, a apenas quatro delas. É mister explicitar, ainda, que a doutrina aloca as

\footnotetext{
${ }^{545}$ FRAGOSO, Heleno; HUNGRIA, Nelson. Comentários ao Código Penal. 6. ed. Rio de Janeiro: Forense, 1983. v. 1, t. 2, p. 46.

${ }^{546}$ GONÇALVES, Carlos Roberto. Responsabilidade civil. 6. ed. São Paulo: Saraiva, 1995. p. 385. Roberto Senise Lisboa, nesse ponto, distingue o nexo causal simples, que é aquele formado pela conduta ilícita de apenas um sujeito, do nexo causal plúrimo, que é aquele formado pela conduta ilícita de vários sujeitos. Nesta última forma de nexo causal há, entre os agentes do ato ilícito, solidariedade passiva, nos termos do artigo 942 do CC/2002. LISBOA, Roberto Senise. Manual de direito civil: obrigações e responsabilidade civil, cit., v. 2, p. 517.

${ }^{547}$ GONÇALVES, Carlos Roberto. Responsabilidade civil. 6. ed., cit., p. 385. Agostinho Alvim, com relação às causas sucessivas, traz o seguinte exemplo: "Suponha-se que um prédio desaba por culpa do engenheiro que foi inábil; o desabamento proporcionou o saque; o saque deu como conseqüência a perda de uma elevada soma, que estava guardada em casa, o que, por sua vez gerou a falência do proprietário". ALVIM, Agostinho. op. cit., p. 343; SILVA, Wilson Melo da. Responsabilidade sem culpa e socialização do risco. Belo Horizonte: Ed. Bernardo Álvares, 1962. p. 205.

548“"Ainda nos começos do século XIX, não se tinha feito da causalidade um princípio geral. Como observa H. Mayer, em vão procuraríamos na parte geral das obras de Feuerbach, Machter, Kostlin ou seus contemporâneos uma teoria da relação causal. Coube à doutrina alemã moderna assumir a responsabilidade da elaboração desse importante tema jurídico-penal, e na literatura alemã e depois na italiana é que encontramos as mais valiosas contribuições na matéria, que se tem desenvolvido com o caráter que ora apresenta a partir da segunda metade do século passado”. BRUNO, Aníbal. op. cit., t. 1, p. 321.
} 
teorias a seguir analisadas em grupos diferentes, sendo imperioso reconhecer que não há uniformidade nessa organização entre os doutrinadores. ${ }^{549}$

A primeira delas é a denominada teoria da equivalência dos antecedentes ou da conditio sine qua non, muito estudada na ciência criminal e encontra disposição expressa no artigo 13 do Código Penal, com os seguintes dizeres: "O resultado, de que depende a existência do crime, somente é imputável a quem lhe deu causa. Considera-se causa a ação ou omissão sem a qual o resultado não teria ocorrido". 550

Inicialmente, é curial reconhecer que a sua simplicidade e a maior possibilidade de permitir a indenização, por parte da vítima, são as suas poucas vantagens reconhecidas pela doutrina. $^{551}$

A referida teoria teve origem na tese de Maximiliano von Buri, divulgada na matéria sobre a participação criminal e que acabou por influenciar outros ramos do direito. John Stuart Mill, em seu estudo “A system of logic”, aduziu que todas as condições devem ser igualmente verificadas, porquanto somente a partir da análise de todas elas será possível determinar a verdadeira causa do conseqüente resultado. ${ }^{552}$

Com efeito, é suficiente, de acordo com a mencionada teoria, que o fato causador da responsabilidade apareça como condição sine qua non da lesão, ombreada com outras condições também indispensáveis para o reconhecimento do nexo de causalidade. ${ }^{553}$

\footnotetext{
${ }^{549}$ Aníbal Bruno, ao estudar as teorias do nexo de causalidade as divide em dois grupos: teorias que não vêem diferença entre condição e causa e teorias que diferenciam causa e condição e buscam estabelecer critérios para dentre as condições destacar a causa. BRUNO, Aníbal. op. cit., t. 1, p. 322. Fernando Dias Paloz apud Patrícia Faga Iglecias Lemos sub-divide as teorias referidas em três grupos: as teoria da equivalência, que é a teoria generalizadora; teorias individualizadoras; e teorias mais modernas. LEMOS, Patrícia Faga Iglecias. op. cit., p. 130.

${ }^{550}$ Ao tratar da teoria da equivalência das condições Heleno Cláudio Fragoso aduz que "a equivalência de todos os antecedentes indispensáveis ao surgimento do resultado concreto, qualquer que tenha sido sua categoria ou grau de contribuição para o evento, não distinguindo entre causa, condição ou ocasião: tudo que concorre para o resultado é causa dele”. FRAGOSO, Heleno Cláudio. Lições de direito penal: a nova parte geral. Rio de Janeiro: Foresne, 1987. p. 168.

${ }^{551}$ SILVA, Wilson Melo da. op. cit., p. 224.

${ }^{552}$ LEMOS, Patrícia Faga Iglecias. op. cit., p. 131; Nas lições de E. Magalhães Noronha: "Dentre as teorias que maior prestígio desfrutam, saliente-se a abraçada por nosso estatuto, no art. 11 (Código Penal anterior à reforma da parte geral ocorrida em 1984): a da equivalência dos antecedentes ou da conditio sine qua non. Originária de von Buri, no terreno jurídico, e tendo tido em Kostlin e Berner seus antecessores, é, no campo filosófico, oriunda de Stuart Mill”. NORONHA, E. Magalhães. Direito penal. 5. ed. São Paulo: Saraiva, 1968. v. 1, p. 116; TEPEDINO, Gustavo. Notas sobre o nexo de causalidade. In: Temas de direito civil. Rio de Janeiro: Renovar, 2006. t. 2, p. 64.

${ }^{553}$ MONTEIRO, Washington de Barros. Curso de direito civil: parte geral, cit., p. 277; PEREIRA, Caio Mário da Silva. Responsabilidade civil (de Acordo com a Constituição de 1988), cit., p. 78.
} 
É dizer, se um determinado fato fez parte do conjunto de condições que desencadearam a ocorrência do evento danoso, é possível chegar-se à ilação de que ele também foi causa. Vale dizer que, se sem essa condição a modificação do mundo fenomênico não ocorreria da forma que sucedeu, é ele causa do resultado. "Que eliminada mentalmente a condição, desaparecesse do mesmo modo o resultado - o chamado processo hipotético de eliminação". 554

A grande crítica direcionada a essa teoria é que a responsabilidade, advinda da sua utilização pode chegar ao infinito, ou seja, cair-se-ia no denominado regressus ad infinitum 555 porquanto tudo que de alguma forma tenha colaborado para a eclosão do resultado será considerado causa, razão pela qual é denominada equivalência dos antecedentes. Ademais, essa teoria não permite distinguir a condição de maior efeito para o nascimento do dano e a que, apenas remotamente, auxiliou o seu surgimento. ${ }^{556}$

Destarte, a pergunta que se deveria fazer para estabelecer o nexo de causalidade, de acordo com debatida teoria é a seguinte: O prejuízo ocorreria sem o fato indicado como sua causa? É mister explicitar que as condições e causas possuem função de concausas, de forma que não há diferença entre causa e ocasião, causa e condição e, como referido, causa e concausa. ${ }^{557}$ Haveria relação de causa e efeito quando caso afastada a causa, desaparecesse também a conseqüência.

Em um crime de homicídio, e.g, com a utilização de uma faca pelo sujeito ativo do delito, adotando-se a teoria da equivalência das condições, poder-se-ia imputar o resultado danoso inclusive a quem fabricou a faca, o que seria um verdadeiro absurdo, a não ser que o fabricante tivesse agido com dolo de auxiliar na infração penal acima referida, o que configuraria o instituto do concurso de pessoas previsto no artigo 29 do CP e a sua conseqüente responsabilização na medida de sua culpabilidade.

\footnotetext{
${ }^{554}$ BRUNO, Aníbal. op. cit., t. 1, p. 323.

${ }^{555}$ JESUS, Damásio E. de. Direito penal: parte geral. 10. ed. São Paulo: Saraiva, 1985. v. 1, p. 218; NUCCI, Guilherme de Souza. op. cit., p. 132; PEREIRA, Caio Mário da Silva. Responsabilidade civil (de Acordo com a Constituição de 1988), cit., p. 78; TEPEDINO, Gustavo. Notas sobre o nexo de causalidade, cit., t. 2, p. 67.

${ }^{556}$ MONTEIRO, Washington de Barros. Curso de direito civil: parte geral, cit., p. 277-278.

${ }^{557}$ NORONHA, E. Magalhães. op. cit., v. 1, p. 116; FRAGOSO, Heleno; HUNGRIA, Nelson. op. cit., v. 1 , t. 2, p. 46.
} 
$\mathrm{Na}$ esfera penal, essa teoria tem o grau de atribuibilidade aferido e mitigado pelos elementos subjetivos do tipo, quais sejam, o dolo e a culpa, ${ }^{558}$ que se tornam meios de impedir a difusão da responsabilidade criminal para pessoas que não concorreram voluntariamente para o evento criminoso. ${ }^{559}$ Dessa forma, pode-se concluir que a debatida teoria situa-se unicamente na seara do elemento físico ou material do crime e, em razão disso, por si só, não satisfaz a punibilidade. ${ }^{560}$

Todavia, tal relatividade, além de ser inoperante na hipótese de tratar-se de responsabilidade objetiva, traz uma confusão entre a imputatio facti e a imputatio juris, uma vez que são coisas diversas o mundo das causas objetivas e materiais e o mundo psicológico. ${ }^{561}$

A debatida teoria foi extremamente criticada pelos doutrinadores penalistas e civilistas que visualizavam a sua pertinência perante a filosofia, ${ }^{562}$ não obstante a sua imprecisão, inclusive no direito penal, sendo arredada peremptoriamente a sua utilização no campo do direito civil, ${ }^{563}$ apesar de ser considerada cientificamente mais exata para Demogue que, mesmo assim, questiona a respeito da possibilidade de sua utilização por força de sua aptidão em disseminar a responsabilidade civil. ${ }^{564}$

Vários são os problemas vislumbrados com a sua utilização, sendo os principais a impossibilidade da atenuação da responsabilidade, no caso de culpa concorrente da vítima $^{565}$ e a indiferença de tratamento entre causas e concausas conforme referido.

Posto isso, seria necessário que se procedesse à relativização da implementação dessa teoria, da forma como boa parcela da doutrina tentou fazer isso, devendo-se diferenciar a concausa que seja relevante juridicamente, daquela juridicamente irrelevante

\footnotetext{
${ }^{558}$ MIRABETTE, Julio Fabrini. Código Penal interpretado. 2. ed. São Paulo: Atlas, 2001. p. 139.

${ }^{559}$ NUCCI, Guilherme de Souza. op. cit., p. 132.

${ }^{560}$ NORONHA, E. Magalhães. op. cit., v. 1, p. 117.

${ }^{561}$ SILVA, Wilson Melo da. op. cit., p. 212. Nas lições de Serpa Lopes: "Quando se cogita da imputabilidade ou da culpabilidade, temos que determinar quais as condições necessárias a que um resultado deva ser imputado subjetivamente ao seu autor, enquanto o problema do nexo causal diz respeito às condições mediante as quais um dano deve ser imputado objetivamente à ação ou omissão de uma pessoa. No primeiro caso, temos uma questão de imputatio iuris, ao passo que, na segunda, um problema de imputatio facti. Na imputatio iuris impõe-se responder ao seguinte questionário: o causador do dano deve ser também considerado dele culpado, para os efeitos da responsabilidade?" LOPES, Miguel de Serpa. Curso de direito civil: fontes acontratuais das obrigações. Responsabilidade civil, cit., p. 219.

${ }^{562}$ SILVA, Wilson Melo da. op. cit., p. 209.

${ }^{563}$ LEMOS, Patrícia Faga Iglecias. op. cit., p. 131.

${ }^{564}$ PEREIRA, Caio Mário da Silva. Responsabilidade civil (de Acordo com a Constituição de 1988), cit., p. 79-80.

${ }^{565}$ LEMOS, Patrícia Faga Iglecias. op. cit., p. 132.
} 
possibilitando, por conseguinte, a análise escorreita, do ponto de vista da justiça, do fato jurídico. ${ }^{566}$

Dessarte, em virtude de se consubstanciar em uma teoria naturalística, podendo-se chegar ao infinito, entende-se que não é recomendável a sua utilização, no instituto da responsabilidade civil, porquanto a sua imprecisão dificultaria sobremaneira a imposição de limites no momento da imputação. ${ }^{567}$ Não obstante, como será exposto, em nossa opinião, essa teoria tem a sua relevância para o direito civil, em virtude de expressa norma de abertura sistemática em nosso diploma civilista, qual seja, o seu art. 935.

Entretanto, duas outras teorias se digladiariam entre os civilistas, como as mais adequadas para a aferição da responsabilidade na esfera do direito civil, inobstante o fato de que apenas uma delas teria expressa previsão no Código Civil de 2002.

Assim, fala-se na teoria da causalidade adequada e na teoria da causalidade direita ou imediata.

A primeira delas define a causa da seguinte forma: causa é toda ação ou omissão abstratamente idônea para a eclosão do resultado. É a condição que demonstra ser a mais adequada à produção do resultado. ${ }^{568}$ Assim, essa teoria da causalidade adequada, teve Luis Von Bar (1871) como seu formulador. No entanto, vale a pena relatar que J. Von Kries, em 1888, a definiu com propriedade. ${ }^{569}$

Essa teoria teve mais partidários entre os penalistas, apesar da adoção expressa, no artigo 13 do Código Penal, da teoria da equivalência dos antecedentes. É curial mencionar que, na subdivisão proposta por Fernando Diaz Palos, a teoria da causalidade adequada

\footnotetext{
${ }^{566}$ LISBOA, Roberto Senise. Manual de direito civil: obrigações e responsabilidade civil, cit., v. 2, p. 524.

${ }^{567}$ LEMOS, Patrícia Faga Iglecias. op. cit., p. 131; GAGLIANO, Pablo Stolze; PAMPLONA FILHO, Rodolfo. Novo curso de direito civil: responsabilidade civil. 4. ed. São Paulo: Saraiva, 2006. v. 3, p. 88; LISBOA, Roberto Senise. Manual de direito civil: obrigações e responsabilidade civil, cit., v. 2, p. 523.

${ }^{568}$ BRUNO, Aníbal. op. cit., t. 1, p. 324.

${ }^{569}$ LEMOS, Patrícia Faga Iglecias. op. cit., p. 134-135. De acordo com o escólio de Gustavo Tepedino: "Já nos termos da teoria da causalidade adequada, concebida pelo filósofo alemão Von Kries, ainda no final do século XIX, e aperfeiçoada por Rümelin, Traeger, Enneceerus e Gabriel Marty, procura-se identificar, na presença de mais de uma possível causa, qual aquela potencialmente apta a produzir os efeitos danosos, independentemente das demais circunstâncias que, no caso concreto, operaram em favor de determinado resultado". TEPEDINO, Gustavo. Notas sobre o nexo de causalidade, cit., t. 2, p. 67.
} 
encontrar-se-ia entre as doutrinas individualizadoras, que são aquelas que tentam "destacar um antecedente do resultado para lhe atribuir o caráter de causa". 570

Para Nelson Hungria a teoria da causalidade adequada não diferencia causa da condição. ${ }^{571}$ Possui ela igual ponto de partida da teoria da conditio sine qua non, ou seja, para ser considerado causa, o evento deve ser, inicialmente, "condição necessária", condição imprescindível do fato lesivo. ${ }^{572}$

De acordo com Patrícia Faga Iglecias Lemos:

"Esta teoria trabalha com a adequação da causa em razão da possibilidade ou probabilidade de um resultado. Adequação no sentido de adaptação, ou seja, o efeito deve ser apropriado à forma de agir do sujeito em função do dano resultante, que era de esperar para aquelas condições. Com isso, para que exista nexo causal, a ação deve ser idônea para produzir aquele resultado. A noção de causalidade adequada supõe que na pluralidade de casos será causa aquilo que normalmente ocorre em situações semelhantes". 573

E continua explicando:

"Realiza-se a chamada 'prognose póstuma', que consiste em analisar do resultado as condições que lhe foram precedentes, para verificar o que teria sido a causa, com a seguinte questão: a ação ou omissão que se analisa era por si apta ou adequada para provocar normalmente essa conseqüência?" 574

Nesse diapasão, causa não é toda ação ou omissão que de alguma forma tenha ajudado na produção do resultado, conforme a teoria da equivalência dos antecedentes. Há de haver um grau de probabilidade que será identificado teoricamente. Vale dizer, utilizase a experiência do desdobramento natural dos fatos para indicar se há ou não nexo de causalidade entre a conduta e o resultado. ${ }^{575}$

Decerto, a verificação da responsabilidade de alguém, de acordo com essa teoria, deve passar pelo crivo da abstração, no que se refere à sua adequabilidade para causar o

\footnotetext{
${ }^{570}$ MARQUES, José Frederico. Curso de direito penal: da infração penal. São Paulo: Saraiva, 1956. v. 2, p. 92-93.

${ }^{571}$ FRAGOSO, Heleno; HUNGRIA, Nelson. op. cit., v. 1, t. 2, p. 46.

${ }^{572}$ MONTEIRO, Washington de Barros. Curso de direito civil: parte geral, cit., p. 278.

${ }^{573}$ LEMOS, Patrícia Faga Iglecias. op. cit., p. 134-135.

${ }^{574}$ Id. Ibid., p. 135.

${ }^{575}$ BRUNO, Aníbal. op. cit., t. 1, p. 325; NORONHA, E. Magalhães. op. cit., v. 1, p. 115; PEREIRA, Caio Mário da Silva. Responsabilidade civil (de Acordo com a Constituição de 1988), cit., p. 79.
} 
resultado danoso. Utiliza-se um dado estatístico como fundamento desse juízo. ${ }^{576}$ Todavia, a crítica que paira sobre essa teoria é o seguinte: o seu apelo à probabilidade e previsibilidade da lesão acabaria trazendo a análise para a seara da culpa, o que produz um conflito entre causalidade e culpa. ${ }^{577}$

A referida confusão entre a culpa e a causalidade é o resultado da sugestão de von Kries ao preconizar que o grau de probabilidade deveria ser averiguado de acordo com a previsibilidade do próprio sujeito. A solução para essa problemática foi a adoção do critério da chamada prognose objetiva posterior, sugerido por Max Rumelin. O que teria importância, para esse autor, não seria a previsibilidade do sujeito aprioristicamente, mas a sua análise ex post, realizada pelo juiz, de todas as condições que fizeram parte do evento, tanto as conhecidas do autor da lesão quanto as desconhecidas. ${ }^{578}$

Contudo, ainda que se considerem as críticas acima aventadas, essa teoria trouxe à responsabilização um critério mais objetivo. ${ }^{579}$

Sérgio Cavalieri Filho, citando Antunes Varela, traz exemplo de aplicação da teoria da causalidade adequada:

"se alguém retém ilicitamente uma pessoa que se apressava para tomar
certo avião, e teve, afinal, de pegar um outro, que caiu e provocou a
morte de todos os passageiros, enquanto o primeiro chegou sem incidente
ao aeroporto de destino, não se poderá considerar a retenção ilícita do
indivíduo como causa (jurídica) do dano ocorrido, porque, em abstrato,
não era adequada a produzir tal efeito, embora se possa asseverar que este
(nas condições em que se verificou) não se teria dado se não fora o ilícito.
A idéia fundamental da doutrina é a de que só há uma relação de
causalidade adequada entre o fato e o dano quando o ato ilícito praticado
pelo agente seja de molde a provocar o dano sofrido pela vítima, segundo
o curso normal das coisas e a experiência da vida". . $^{\circ}$.

Com efeito, o que determinará a existência ou não do nexo de causalidade e a consequente atribuibilidade do resultado danoso é a adequação, de acordo com o desencadeamento natural das coisas, de algum antecedente fático potencializador dessa modificação prejudicial no mundo fenomênico.

\footnotetext{
${ }^{576}$ BRUNO, Aníbal. op. cit., t. 1, p. 326.

${ }^{577}$ LEMOS, Patrícia Faga Iglecias. op. cit., p. 136.

${ }^{578}$ BRUNO, Aníbal. op. cit., t. 1, p. 326; SILVA, Wilson Melo da. op. cit., p. 217.

${ }^{579}$ LEMOS, Patrícia Faga Iglecias. op. cit., p. 136.

${ }^{580}$ CAVALIERI FILHO, Sérgio. Programa de responsabilidade civil. 2. ed. 3. tir. São Paulo: Atlas, 2000. p. 51.
} 
Impende destacar, entrementes, que a probabilidade não se confunde com a certeza, razão pela qual a teoria da causalidade adequada, não obstante ter surgido carregada de prestígio, entrou em decadência em virtude das críticas que lhe foram direcionadas pela sua citada incerteza. ${ }^{581}$

Von Kries, ao caracterizar a causa limitativa que tenha o condão de ser a mais adequada e relevante de todas, construiu uma teoria mais filosófica e teórica do que jurídica e prática. O referido "saber" ontológico causou divergência extrema entre os doutrinadores, a ponto de a teoria perder a pretendida precisão. ${ }^{582}$

A outra teoria, a da causalidade direta ou imediata ou dos danos direitos e imediatos foi melhor desenvolvida, entre nós, por Agostinho Alvim sendo que, para a maioria da doutrina $^{583}$ é a mais condizente com o nosso ordenamento jurídico, expressando-se no atual Código Civil, em seu artigo 403, com os seguintes dizeres: "Ainda que a inexecução resulte de dolo do devedor, as perdas e danos só incluem os prejuízos efetivos e os lucros cessantes por efeito dela direto e imediato, sem prejuízo do disposto na lei processual". 584

Para Wilson Melo da Silva, a teoria dos danos diretos e imediatos é um "amálgama das teorias da equivalência das condições e da causalidade adequada, com certa amenização no que tange às extremas conseqüências a que se pudesse chegar na aplicação, prática, de tais teorias". 585

\footnotetext{
${ }^{581}$ PEREIRA, Caio Mário da Silva. Responsabilidade civil (de Acordo com a Constituição de 1988), cit., p. 79.

${ }^{582}$ SILVA, Wilson Melo da. op. cit., p. 219.

${ }^{583}$ LEMOS, Patrícia Faga Iglecias. op. cit., p. 140. Em sentido contrário, tem-se a posição de Roberto Senise Lisboa que advoga a idéia de que tanto o diploma anterior quanto o atual Código Civil adotaram a teoria da causalidade adequada. LISBOA, Roberto Senise. Manual de direito civil: obrigações e responsabilidade civil, cit., v. 2, p. 524.

${ }^{584} \mathrm{~A}$ nossa jurisprudência também reconhece, com algumas exceções, a adoção em nosso sistema jurídico da teoria da causalidade direita e imediata. Senão vejamos: "De todas as teorias sobre o nexo causal, o nosso Código adotou, indiscutivelmente, a do dano direto e imediato, como está expresso no art. 403 do CC/2002, que já existia no artigo 1.060 do CC de 1916. Dispõe com efeito o mencionado dispositivo legal: "Ainda que a inexecução resulte de dolo do devedor, as perdas e danos só incluem os prejuízos efetivos e os lucros cessantes por efeito dela direto e imediato, sem prejuízo no disposto na lei processual" (Ap. Cív. c/Revisão n. 1028817 - 0/9, rel. Des. Rui Coppola, j. 14.6.2007); neste mesmo sentido: TJDF: "A par de ter-se alinhado o Direito Civil brasileiro à teoria subjetiva da responsabilidade aquiliana (art. 159 do CCB de 1916 e 186 do CCB de 2002), também adotou-se a teoria da causalidade direta ou imediata, consoante se extrai do art. 403 do vigente Código Civil (Art. 1.060 do Código Civil revogado), segundo a qual somente a causa imediata ou remota, pode ensejar a responsabilidade" (Ap. Cív. N. 2004031 017109-3, rel. Des. Humberto Adjuto Ulhôa, j. 24.10.2005).

${ }^{585}$ SILVA, Wilson Melo da. op. cit., p. 206.
} 
Essa teoria foi consagrada pelo Código Napoleão, inspirado nos ensinamentos de Pothier, que reproduziu as lições de Dumoulin, em seu art. 1.151, e pelo atual Código Civil Italiano, em seu art. $1.223 .^{586}$

De acordo com Carlos Roberto Gonçalves:

"Tal teoria foi denominada por Enneccerus teoria da interrupção do nexo causal. A interrupção do nexo causal ocorreria, segundo seu ensinamento, toda vez que, devendo impor-se um determinado resultado como normal consequiência do desenrolar de certos acontecimentos, tal não se verificasse pelo surgimento de uma circunstância outra que, com anterioridade fosse aquela que acabasse por responder por esse mesmo esperado resultado. Tal circunstância outra se constituiria na chamada causa entranha". 587

Deveras, o sujeito primeiro se responsabilizaria pelas lesões perpetradas na esfera jurídica de terceiros que se prendessem à sua conduta por um elo de necessariedade. Pelas lesões advindas das causas estranhas deveriam responder os respectivos sujeitos. ${ }^{588}$

Wilson Melo da Silva observa que, em passagem de Paulo, no jus romanum, já se poderia afirmar presente o germe da teoria da relação causal imediata. ${ }^{589}$

Agostinho Alvim entende que é o supracitado dispositivo do nosso atual Código Civil (art. 403) que deve ser estudado para a mais adequada apreciação da teoria acolhida por nosso sistema jurídico, no que diz respeito ao nexo de causalidade. É essa a posição, segundo ele, da grande maioria dos civilistas, na França, na Itália e entre nós. ${ }^{590}$

Todavia, adverte Agostinho Alvim que a precisa delimitação de seus contornos e limites é tarefa difícil e, dessa maneira, muitas Escolas apareceram com o escopo de descobrir uma fórmula apta a resolver todas as hipóteses. De acordo com o seu ponto de vista, a Escola mais consentânea, em que são seus expositores Giorgi, Chironi, Polacco e outros, é a da consequência necessária. ${ }^{591}$

\footnotetext{
${ }^{586}$ ALVIM, Agostinho. op. cit., p. 346.

${ }^{587}$ GONÇALVES, Carlos Roberto. Responsabilidade civil. 6. ed., cit., p. 387.

${ }^{588}$ SILVA, Wilson Melo da. op. cit., p. 236.

589 "Se, como relembra Paulo na passagem sua, mencionada no Digesto, vêm a morrer de fome os escravos daquele que encomendou, a certo vendedor, o trigo que, desse mesmo vendedor não recebeu, por tal dano (morte dos escravos) não se poderia responsabilizar o dito vendedor". SILVA, Wilson Melo da. op. cit., p. 231.

${ }^{590}$ ALVIM, Agostinho. op. cit., p. 342-343.

${ }^{591}$ Id. Ibid., p. 347.
} 
Contudo, a Escola de Mosca, denominada de teoria da causalidade jurídica, inobstante a acirrada crítica que lhe fora endereçada é bem interessante, porquanto trabalha com o corte de nexo de causalidade, a partir da atuação de um ato ilícito voluntário por quem seja imputável, porque o fato natural não tem o condão de romper o nexo de causalidade. Vale dizer, apenas o surgimento de um intermediário culpado pode ter a pretensa aptidão de interromper o elo causal. ${ }^{592}$

Ocorre que Tomaso Mosca utiliza uma expressão não muito exata, qual seja, ato ilícito de terceiro ou de credor, pode gerar distúrbios em sua aplicação, haja vista a circunstância de que o próprio credor pode praticar uma conduta que rompa o nexo de causalidade anterior, ainda que não seja ilícita, o que elidirá a responsabilidade do autor do ato primitivo. ${ }^{593}$

De outra forma, a idéia fundamental da teoria da consequência necessária é o corte do nexo de causalidade, a partir de uma nova atuação que liberta o agente da primeira causa, havendo, não obstante, muitas divergências nos casos em que fatos naturais interrompem esse nexo. ${ }^{594}$

Ocorrido certo dano, será considerada a sua causa aquela que lhe é próxima ou remota. Contudo, sobreleva reconhecer que, em relação a esta última é necessário que ela se ligue ao dano, imediatamente. Destarte, é indenizável toda lesão que seja filiada a uma causa, ainda que remotamente, com a condição de estar vinculada por uma relação de necessariedade e não exista outra que explique a mesma lesão. Para a lei, o prejuízo deve ser efeito imediato e direito do evento. 595

Assim, realizado o ato lesivo, ao qual não for exigido, de acordo com a doutrina atinente à responsabilidade objetiva, a imputabilidade do sujeito como condição de obrigá-

\footnotetext{
${ }^{592}$ ALVIM, Agostinho. op. cit., p. 350.

593،Por isso, entendemos que, com relação ao credor, não é o ato ilícito que rompe o nexo de causalidade, e sim, o fato que se lhe pode imputar, e que seja a última causa do dano, desde que seja um ato irregular". ALVIM, Agostinho. op. cit., p. 350.

${ }^{594}$ LEMOS, Patrícia Faga Iglecias. op. cit., p. 138. A autora adverte que a referida teoria possui algumas subteorias, aduzindo que merece destaque a teoria de Tomaso Mosca denominada de causalidade jurídica, de acordo com a qual quando muitos são os fatos ilícitos há uma divisão entre aqueles que se reputam causa direta e imediata e aqueles que são a causa indireta e mediata.

${ }^{595}$ ALVIM, Agostinho. op. cit., p. 356.
} 
lo a reparar ou compensar o dano, a problemática do nexo causal não assimilaria as dificuldades encontradas pelas outras duas teorias referentes ao liame de causalidade. ${ }^{596}$

Não se pode olvidar que, culpabilidade e causalidade são fenômenos jurídicos distintos, de forma que a segunda é elemento compatível tanto com a responsabilidade subjetiva quanto com a responsabilidade objetiva. ${ }^{597}$

Para um estudo mais adequado, sobre a debatida teoria, deve-se fazer uma análise da expressão "direto e imediato" para que seja possível aferir o seu real significado. De fato, a palavra "imediato" tem o significado de algo sem intervalo, ao passo que "direto" significa alguma coisa que vem em linha reta, com ou sem intervalo. Destarte, afastada estaria a sinonímia entre os dois termos, de forma que o legislador poderia, em tese, desejar atribuir significados diversos às expressões. ${ }^{598}$

Demais disso, para corroborar suposta assertiva poder-se-ia dizer que o legislador, em regra, não utiliza palavras inúteis. Entretanto, insta destacar que há doutrinadores que pensam de forma diametralmente oposta, posto que é corrente a utilização dos termos como sinônimos. 599

Em realidade, a melhor interpretação que a doutrina estrangeira tem conferido, de acordo com Agostinho Alvim, é que: as expressões em debate, uma vez que foram incorporadas no texto, conjuntamente, refletem uma idéia de ênfase, de forma a traduzir a noção de necessariedade. Ou seja, a lesão "deve ser conseqüência necessária da inexecução da obrigação". 600

Sobreleva ressaltar que os autores estrangeiros, dentre eles Pothier, Colin Et Capitant, quando tratam dessa teoria afirmam que é o surgimento de uma concausa que rompe o nexo de causalidade, o que significa dizer que não é relevante a distância entre o evento e a lesão. ${ }^{601}$

É imperioso reconhecer que das várias teorias sobre o nexo de causalidade, o nosso diploma civil perfilhou a do dano direto e imediato, fato este que seria de difícil discussão,

\footnotetext{
${ }^{596}$ SILVA, Wilson Melo da. op. cit., p. 236.

${ }^{597}$ Id. Ibid., p. 237.

${ }^{598}$ ALVIM, Agostinho. op. cit., p. 357.

${ }^{599}$ Id. Ibid., p. 357-358.

${ }^{600}$ Id. Ibid., p. 359.

${ }^{601}$ Id. Ibid., p. 363.
} 
porquanto expresso no art. 403 e, ${ }^{602}$ das muitas Escolas que tentam explicar essa teoria, a melhor é a aquela que se reporta à consequência necessária, apesar de imperfeições que as dificuldades inerentes a certos casos práticos colocam a descoberto. ${ }^{603}$ Nesse sentido, Gustavo Tepedino leciona que o próprio STF, desde a entrada em vigor da Constituição Federal de 1998, adota a teoria da causalidade direta ou imediata, prevista no artigo 403 do atual Código Civil, para o estabelecimento do nexo de causalidade. ${ }^{604}$

\begin{abstract}
"E se ideal não se pode afirmar que seja o critério objetivo, da limitação do nexo causal pelo acolhimento do princípio da necessariedade entre determinada causa e determinado dano, força é convir, no entanto, que ele nos pode levar a resultados mais equânimes que aqueles a que se aspirasse pela adoção do só critério limitador, subjetivo, da culpa, quase sempre de problemática apuração, notadamente quando se tem pela frente uma daquelas hipóteses da chamada culpa levíssima da velha tricotomia dos romanos". ${ }^{605}$
\end{abstract}

Gustavo Tepedino observa, entretanto, que há vacilos na jurisprudência no momento de denominar a teoria perfilhada por nosso sistema quanto ao nexo de causalidade. Existe verdadeira confusão conceitual, porque o STF prefere a denominação de teoria de interrupção do nexo causal, enquanto o STJ, em seus julgados, utiliza a nomenclatura de teoria da causalidade adequada. Contudo, em ambas as circunstâncias o nexo de causalidade exige a causalidade necessária entre a causa e o prejuízo para o estabelecimento da responsabilidade civil. ${ }^{606}$

Juan Espinoza Espinoza, ao comentar o art. $1.321^{\circ}$ do Código Civil peruano, similar ao art. 403 do atual Código Civil pátrio, confere uma interpretação um pouco diversa

\footnotetext{
${ }^{602}$ É interessante notar que, de acordo com a doutrina de Juan Espinoza Espinoza, o sistema civil peruano adotara teorias diversas com relação ao nexo de causalidade em matéria de responsabilidade civil contratual e extracontratual. Com efeito, são essas as suas palavras: "Se afirma que en materia de responsabilidad civil extracontratual o aquiliana se acoge la teoría de la causa adecuada (Art. $1985^{\circ}$ c.c) y en inejecución de las obligaciones se asume la teoría de la causa próxima (Art. $1321^{\circ}$ c.c., segundo párafo), el qual establece: 'el resarcimiento por la inejecución de la obligación o por su cumplimiento parcial, tardío o defectuoso, comprede tanto el daño emergente como el lucro cesante, en cuanto sean consecuencia inmediata y direta de tal inejecución"”. ESPINOZA ESPINOZA, Juan. op. cit., p. 748.

${ }^{603}$ ALVIM, Agostinho. op. cit., p. 363. Nas lições de Maria Helena Diniz, em comentários ao artigo 403, antigo 1.060, tem-se que: "A lei só admite indenização de perdas e danos decorrentes da inexecução dolosa da obrigação pelo devedor quando direta e imediata, sem prejuízo do disposto na lei processual. Logo serão insuscetíveis de indenização prejuízo eventual ou potencial. A obrigação indenizatória liga-se, portanto, ao dano efetivo e ao lucro cessante, oriundos, diretamente, do inadimplemento obrigacional. Adotada está a doutrina da causalidade direta e imediata." DINIZ, Maria Helena. Código Civil anotado, cit., p. 387.

${ }^{604}$ TEPEDINO, Gustavo. Notas sobre o nexo de causalidade, cit., t. 2, p. 64.

${ }^{605}$ SILVA, Wilson Melo da. op. cit., p. 238.

${ }^{606}$ TEPEDINO, Gustavo. Notas sobre o nexo de causalidade, cit., t. 2, p. 76.
} 
daquela tradicionalmente conferida pela nossa doutrina, afirmando que a sua função não é a de regular a relação de causalidade, função esta exercida pelo art. $1985^{\circ}$ do comentado diploma, mas demonstrar o montante a ser indenizado pelo agente causador do dano. Assim, preconiza o referido autor que o nexo de causalidade possui a finalidade não só de estabelecer a relação de causa efeito entre o ato e a lesão (causalidade de fato ou fática), quanto de precisar o quantun a ser ressarcido (causalidade jurídica) à vítima. ${ }^{607}$

Entretanto, em nossa opinião, parece incorrer em equívoco a assertiva a respeito da exclusiva adoção da teoria do dano direito e imediato em nosso sistema civil, ${ }^{608}$ porquanto há abertura normativa, no próprio Código Civil, permitindo concluir que outras teorias também são incorporadas.

De fato, essa afirmação passa pela análise da circunstância de que a coisa julgada, na esfera criminal, ${ }^{609}$ quando decidida afirmativamente acerca da autoria e materialidade produz efeitos no juízo cível, nos termos do artigo 935 do atual Código Civil. Dessarte, não seria possível desconsiderar, a priori, a adoção indireta também pelo sistema civil da teoria da equivalência dos antecedentes.

\footnotetext{
${ }^{607}$ In verbis: "En materia de responsabilidad civil por incuplimiento de las obligaciones, el segundo párrafo in fine del Art. $1321^{\circ}$ c.c., al precisar que se generará el resarcimiento por inejecución de la obligación, en cuanto los daños 'sean consecuencia inmediata y directa de tal inejecución', se refiere a la causalidad jurídica, entendida como aquella que delimita la magnitud de la responsabilidad del dañante, el cual, incluso, no debe ser entendido de manera literal, sino interpretado bajo el principio de reparación integral de la víctima. En materia de responsabilidad extracontratual, el Art. $1985^{\circ}$ c.c., al establecer que se generará la indeminización 'debiendo existir uma relación de causalidad adecuada entre el hecho y el daño producido', se refiere a la causalidad de hecho, entendida como uno de los elementos constitutivo del supuesto de responsabilidad civil, el cual determina la relación entre el hecho y el daño". ESPINOZA ESPINOZA, Juan. op. cit., p. 756.

608،A adoção, pelo Supremo Tribunal Federal brasileiro, da teoria do dano direto e imediato, afasta a aplicação das duas outras teorias conhecidas pela dogmática do direito civil: as teorias da equivalência das condições e a da causalidade adequada". TEPEDINO, Gustavo. Notas sobre o nexo de causalidade, cit., $t$. 2, p. 66.

${ }^{609}$ Francesco Carnelutti, ao discorrer acerca da eficácia civil da coisa julgada penal assevera que: "O fenômeno da interferência das situações jurídicas, consistente em que um mesmo fato possa ter mais de uma conseqüência jurídica, enquanto tais consequiências pertençam respectivamente ao Direito Civil e ao Direito Penal, faz com que a declaração de certeza de uma relação jurídica penal possa desenvolver eficácia também sobre as relações jurídicas civis conexas. A esse fenômeno se refere o problema do valor civil da coisa julgada penal. Tal problema não se apresenta quando a sentença penal é pronunciada perante a parte civil ou o responsável civil, pois em tais casos, que representam uma extensão do processo penal no campo civil, a sentença não tem só caráter penal, como também o de uma sentença civil, embora pronunciada em sede penal; o processo penal com parte civil ou com responsável civil é um processo cumulativo verdadeiro, o qual serve ao mesmo tempo tanto para a verificação da pretensão penal como para a composição de uma ou várias lides civis”. CARNELUTTI, Francesco. Instituições do processo civil. Tradução: Adrián Sotero De Witt Batista. Campinas/SP: Servanda, 1999. v. 1, p. 211-212.
} 
Com efeito, os doutrinadores criminalistas, como referido alhures, advogam a idéia da adoção da teoria da equivalência dos antecedentes, no art. 13 do Código Penal. Ora, se a análise do nexo de causalidade, na hipótese de prática de infração penal, passará pelo crivo da teoria da conditio sine qua non, é forçoso convir que, caso seja prolatada uma sentença condenatória produtora de consequências no juízo cível, a teoria da equivalência dos antecedentes é de suma importância, outrossim, para o direito civil.

Por último, será analisada a teoria da imputação objetiva, também disseminada pelos penalistas, ${ }^{610}$ apesar de ter sido desenvolvida inicialmente para ser utilizada no Direito Civil. ${ }^{611}$ Todavia, impende ressaltar que, até o momento, não alcançou o prestígio que seus defensores pretendiam, perante o nosso sistema jurídico criminal.

Com efeito, a teoria da imputação objetiva ainda se encontra em desenvolvimento. Não há, entre os doutrinadores, pacificidade no que tange aos seus limites e contornos, sendo considerada uma forma de restringir a teoria da relação causal. A referida teoria é dominante na Espanha e na Alemanha, contudo não goza de muita aceitação no Brasil e na América Latina. ${ }^{612}$

Foi desenvolvida, ns sua tese de doutorado, por Larenz (1927), que trabalhou a referida teoria com a ideia de risco permitido e proibido. Nesse sentido, a vida em sociedade exige que as pessoas estejam expostas cotidianamente a situações de risco, porém, deve-se distinguir as circunstâncias em que o risco é vedado daquelas em que o risco é aceito pelo sistema normativo. Dessa forma, alguns riscos necessitam ser tolerados. $^{613}$

O ilícito derivaria da criação de um risco proibido. Para essa teoria limitadora do nexo de causalidade, ${ }^{614}$ o liame causal dependerá do comportamento do sujeito que tenha criado para o bem jurídico tutelado uma situação de risco vedado e esse risco tenha sido posteriormente a causa do resultado danoso.

\footnotetext{
${ }^{610}$ DELMANTO, Celso. Código Penal comentado. 6. ed. Rio de Janeiro: Renovar, 2002. p. 22.

${ }^{611}$ GAGLIANO, Pablo Stolze; PAMPLONA FILHO, Rodolfo. Novo curso de direito civil: responsabilidade civil, cit., v. 3, p. 97.

${ }^{612}$ JESUS, Damásio E. de. Imputação objetiva. 3. ed. São Paulo: Saraiva, 2007. p. 24.

${ }^{613}$ LEMOS, Patrícia Faga Iglecias. op. cit., p. 141; NUCCI, Guilherme de Souza. op. cit., p. 133.

${ }^{614}$ GAGLIANO, Pablo Stolze; PAMPLONA FILHO, Rodolfo. Novo curso de direito civil: responsabilidade civil, cit., v. 3, p. 98-99.
} 
De acordo com a teoria da imputação objetiva, cujo maior expoente é Claus Roxin, da escola alemã, um resultado não pode ser atribuído a um agente por uma relação de causalidade, exige-se um outro nexo que se materializa na circunstância criadora de um risco vedado pelo direito. ${ }^{615}$

Vale dizer, a teoria da imputação objetiva exige, grosso modo, para que uma pessoa seja responsabilizada por ato que desenvolveu, a criação ou incremento de um risco juridicamente proibido ao bem jurídico tutelado, assim como a concretização desse risco em resultado danoso. Por exemplo: o agente, que, guiando automóvel em alta velocidade, em área habitada, perde o controle do veículo, sobe no passeio público e atropela um transeunte que caminhava tranquilamente em local permitido, deverá ser responsabilizado por homicídio. Criou um risco intolerável e não permitido ao transitar pela rua em excesso de velocidade. ${ }^{616}$

A definição de risco permitido pode ser extraída a partir da análise do progresso da sociedade, mormente no que tange as descobertas e invenções de novas tecnologias e técnicas em muitos setores. ${ }^{617}$ É evidente que várias são as vezes em que a invenção de aparelhos traz o perigo não apenas para aqueles que deles se utilizam como para outras pessoas que, não rara vez, sofrem os efeitos dessa utilização. No entanto, a vida social exige essa subordinação do homem ao risco sob pena de estagnação.

O risco tolerado tem conceito ontológico e axiológico. Ontologicamente, a análise da existência ou não do perigo deve considerar dados do ser, sem levar em consideração aspectos normativos. Axiologicamente, insta destacar que a fronteira entre o permitido e vedado deriva das normas de cuidado impostas pela vida social. ${ }^{618}$

A distinção entre o risco tolerado e vedado não se encontra na gravidade do perigo, mas no fato de que, por vezes, é lícito e outras vezes não. Vale dizer, o risco faz parte do mundo natural e, como consabido, é inerente à nossa vida. Por outro lado, a permissão ou vedação são determinadas pelo conjunto de normas que ordenam a sociedade. "A

\footnotetext{
${ }^{615}$ NUCCI, Guilherme de Souza. op. cit., p. 133.

${ }^{616}$ Id., loc. cit.

${ }^{617}$ JESUS, Damásio E. de. Imputação objetiva, cit., p. 40.

${ }^{618}$ Id., loc. cit.
} 
tolerância para a realização da conduta criadora de risco advém das estruturas sociais, que, por intermédio de diferentes critérios, disciplinam o que é lícito e o que é desaprovado". ${ }^{619}$

A prática de conduta carregada de risco tolerado, ainda que produza um resultado lesivo, em regra não poderá ser considerada como típica para o seu autor, sendo denominada por Claus Roxin como algo desprovido de importância ao legislador. ${ }^{620}$

Por essa teoria elimina-se a possibilidade de responsabilização civil e criminal de certas condutas que, diante da teoria da equivalência das condições, seriam certamente consideradas causa do evento lesivo.

Suponhamos que Paulo, desejando assumir a direção de uma empresa, proporcione a Pedro, atual diretor da citada pessoa jurídica, uma viagem para uma praia onde haja registros de muitos ataques de tubarões e, coincidentemente, o diretor, ao entrar na água, é atacado por um deles e falece. ${ }^{621}$ Seria Paulo responsável criminalmente pela morte de Pedro?

Bem, a resposta à pergunta, acima formulada, dependerá da teoria sobre o nexo de causalidade que se adote. Adotando-se a teoria da equivalência das condições, como Paulo pagou a viagem a Pedro e atuou com dolo na ocorrência do resultado, seria certamente responsável por crime de homicídio doloso consumado. ${ }^{622}$

Por outro lado, utilizando-se a teoria da imputação objetiva para o mesmo caso, a resolução do problema atingiria uma posição final diametralmente oposta.

Deveras, oferecer e pagar uma viagem, para uma pessoa se hospedar em uma praia é um comportamento permitido pelo sistema jurídico. No caso em testilha, não houve por parte de Paulo uma conduta criadora de um risco vedado pelo ordenamento normativo. Se Pedro aceitou viajar, hospedar-se em hotel, tudo proporcionado pelo seu colega de empresa e entrou na praia com registros de ataques de tubarões, assumiu, por si só, os riscos de seu ato. Assim, nenhuma responsabilidade poder-se-ia imputar a Paulo.

\footnotetext{
${ }^{619}$ JESUS, Damásio E. de. Imputação objetiva, cit., p. 41.

${ }^{620}$ Id. Ibid., p. 44.

${ }^{621}$ Id. Ibid., p. 27.

${ }^{622}$ Damásio E. de Jesus, analisando exemplo semelhante disserta que: "Estariam presentes, no fato típico, o comportamento doloso, o resultado (morte do pai), o nexo de causalidade (entre a indução e o evento) e a tipicidade. E, ausente causa excludente de antijuridicidade, o filho imputável responderia por homicídio doloso consumado, uma vez exigível conduta diversa e evidente o conhecimento potencial da ilicitude". Id. Ibid., p. 25.
} 
É curial esclarecer que a teoria da imputação objetiva não despreza a da equivalência dos antecedentes - conditio sine qua non - considerada naturalística, de forma a estabelecer o liame entre a conduta e o resultado lesivo, na qual implementará as suas definições. ${ }^{623}$

É mister explicitar, contudo, que a referida teoria não se encontra no plano dos fatos, mas sim dos valores que o direito visa tutelar. O cerne da questão não se encontra na imputação de uma pessoa de acordo com o dogma da causalidade material, não se considera a área das ciências físicas, mas sim o plano jurídico. ${ }^{624}$

Pedro faleceu, no exemplo supracitado, em razão de ter entrado no mar após viagem paga por Paulo. Ou seja, a causa da morte de Pedro também foi a viagem proporcionada por seu colega de trabalho. Até esse momento a teoria da imputação objetiva se valerá da teoria naturalística para delimitar os seus limites de atuação. Não será feita a análise prévia dos elementos subjetivos: o dolo e a culpa, o que ocorrerá só posteriormente. Primeiramente, de acordo com a teoria da imputação objetiva, será feita uma análise da conduta do sujeito para se averiguar se foi ela criadora de um risco intolerável e não permitido pelo ordenamento jurídico. ${ }^{625}$

A teoria da imputação objetiva trabalha, para alguns doutrinadores, igualmente, com a questão da inevitabilidade do resultado, de maneira a realizar um prognóstico do dano e considerar, por consequiência, qualquer conduta que interfira no resultado que, realmente ocorreria, indiferente do ponto de vista da responsabilidade. ${ }^{626}$

Insta reconhecer que a referida teoria ainda é objeto de muita celeuma entre os seus defensores, sendo importante enfatizar que seus limites e contornos não se encontram harmonicamente definidos, a ponto de haver dissonância, entre os doutrinadores,

\footnotetext{
${ }^{623}$ NUCCI, Guilherme de Souza. op. cit., p. 134.

${ }^{624}$ JESUS, Damásio E. de. Imputação objetiva, cit., p. 34.

${ }^{625}$ NUCCI, Guilherme de Souza. op. cit., p. 134.

${ }^{626} \mathrm{O}$ exemplo nos é dado por Damásio E. de Jesus com a denominação de "O Carrasco Frustrado": "Suponha-se uma condenação por fuzilamento do autor de um crime militar em tempo de guerra. Frações de segundo antes de o comandante da tropa dar a ordem de atirar, o inimigo do condenado, com um revólver, desfecha um tiro em sua cabeça, matando-o. Responde pela morte? Note-se que excluída a conduta, nos termos do método de eliminação hipotética, instantes depois seguramente o resultado ocorreria da mesma forma por obra da execução. E causa, para esse sistema, é a ação sem a qual o resultado não teria ocorrido (CP, art. 13 , caput, $2^{\mathrm{a}}$ parte). Logo, a conduta do inimigo da vítima não poderia ser considerada causa da morte, pois sem ela o evento teria acontecido da mesma forma. E a tropa não executou o condenado. Assim, teríamos uma morte sem causa, o que não é correto." JESUS, Damásio E. de. Imputação objetiva, cit., p. 31-32.
} 
dependendo do caso concreto, quanto ao resultado de sua aplicação. O próprio Claus Roxin assevera que "o conceito de risco permitido é utilizado em múltiplos contextos, mas sobre o seu significado e posição sistemática reina a mais absoluta falta de clareza". ${ }^{627}$

Para o direito civil, apesar de útil sua construção, impende ressaltar que com a entrada em vigor do atual Código Civil e a consagração da responsabilidade objetiva, nos termos do parágrafo único do seu art. 927, a sua importância no contexto do nexo de causalidade é sensivelmente mitigada.

Realmente, a diferenciação entre risco permitido e vedado não é abarcada pelo diploma civilista sendo relevante, para a teoria objetiva da responsabilidade civil, que se fundamenta no risco, pura e simplesmente o desenvolvimento de uma atividade pelo autor do prejuízo que implique, por sua natureza, risco na esfera jurídica de terceiro.

Assim, se há risco no desenvolvimento da atividade, nada importa se é ele permitido ou proibido, porquanto ocorrendo o dano, seguramente, o nexo de causalidade será averiguado por meio de outra teoria que não a da imputação objetiva, sob pena de se desnaturar, cabalmente, a estrutura da responsabilidade civil objetiva que se fundamenta na teoria do risco, não se exigindo que essa criação de perigo seja vedada pelo sistema jurídico.

Não obstante, dependendo do caso concreto, é factível sua utilidade no contexto da responsabilidade civil subjetiva que possui estrutura diferente como é cediço.

A guisa de conclusão, dada a dificuldade de se estabelecer a teoria mais adequada, dentre aquelas analisadas nesta dissertação, para estabelecer o nexo de causalidade na responsabilidade civil dos pais pelos atos de seu filhos maiores, entendemos que a melhor solução é o emprego de todas elas no que se mostrem razoáveis. Não é possível descartar, aprioristicamente, qualquer delas. ${ }^{628}$ Fala-se, contemporaneamente, inclusive, em presunção de causalidade para os casos de danos graves e irreverssíveis. ${ }^{629}$

\footnotetext{
${ }^{627}$ apud NUCCI, Guilherme de Souza. op. cit., p. 138.

${ }^{628}$ Juan Espinoza Espinoza, ao tratar do nexo de causalidade no Código Civil peruano, advoga que: "Sin embargo, se cree conveniente que en una eventual reforma legislativa, solo se deberia regular que el demandante de la pretensión resarcitoria tenga la carga de acreditar el nexo causal, sin asumir ninguna teoría causal. Por cuanto la realidad supera las previsiones del legislador". ESPINOZA ESPINOZA, Juan. op. cit., p. 757.

${ }^{629}$ Nesse sentido: “...Em hipóteses graves, têm sido aplicadas as "presunções de causalidade”, baseadas na probabilidade e estatística. A probabilidade, assim como a verossimilhança, se aproxima da verdade, diferentemente da estatística, que não diz nada com relação ao caso concreto. A estatística só serve para o
} 
Demais disso, como demonstrado, o direito civil não se utiliza apenas das teorias da causa direta e imediata ou da causalidade adequada, usa, ainda que indiretamente, em razão do disposto no art. 935, do atual Código Civil, a teoria da equivalência dos antecedentes, posto que essa norma de abertura sistemática traz para o direito civil as consequências da prolação de uma sentença condenatória criminal que, por expresso mandamento, previsto no art. 13 do Código Penal, terá utilizado a teoria da conditio sine qua non para a atribuição de um crime ao sujeito ativo do delito.

A presente dissertação labora com a idéia de que os pais são responsáveis nos termos aqui defendidos por uma série de fatores. A má educação dada aos filhos, durante a fase de crescimento deles, soma-se à facilitação da prática de atos lesivos por parte dos pais que, muitas vezes, após a celebração de contratos com seus descendentes acabam potencializando comportamentos que, certamente, irão trazer prejuízos à esfera jurídica de terceiros.

Ademais, os genitores, que conhecem a incapacidade financeira de seus filhos, acabam criando um risco à esfera jurídica de terceiros ao celebrarem, verbi gratia, um contrato de comodato de automóvel sabendo ou devendo saber que, na eventualidade de seus filhos perpetrarem condutas produtoras de lesões envolvendo esse bem, não terão eles condições de suportar o encargo financeiro necessário à recomposição do patrimônio lesado.

Quem causa dano a outrem deve indenizar. Não indenizando pratica outro ato ilícito, uma vez que há norma expressa que aduz a respeito da responsabilidade patrimonial. Ora, se um progenitor conhece a condição financeira de seu filho e sabe, $a$ priori, que ele não terá possibilidade de ressarcir um eventual dano, cria para o direito de outrem um risco vedado pelo ordenamento e assume, por conseguinte, o dever de reparar ou compensar o prejuízo que seu descendente cause na vida de uma pessoa.

cálculo em contrato de seguro. As "presunções de causalidade" têm sido aplicadas aos danos à saúde, como a presunção de contaminação com o vírus HIV, depois de receber transfusão de sangue. Pode ser que não seja de fato, mas juridicamente é tida como verdadeira essa decisão. Aliás, essa é a aplicação da regra res ipsa loquitur, ou seja, a coisa fala por si mesma, já usada nos casos de erro médico há muito tempo." LOPEZ, Teresa Ancona. Princípio da precaução e evolução da responsabilidade civil, cit., p. 135. 


\section{CONSIDERAÇÕES FINAIS}

O instituto da responsabilidade civil, como demonstrado, passou por modificações profundas no decorrer da história. Iniciou-se com a primitiva confusão dos conceitos de ilícito e culpa, o que revelava a idéia da adoção da responsabilidade objetiva, até o desenvolvimento da noção isolada de culpa, fato este que trouxe o conhecimento da responsabilidade subjetiva e seus corolários para, posteriormente, vislumbrarmos a derrocada da supremacia da culpa e o retorno da responsabilidade civil objetiva, no sistema jurídico. Ou seja, o referido instituto desenvolveu-se perante a ciência jurídica de maneira cíclica.

A exclusão da culpa, em muitos casos, como elemento necessário para o surgimento do dever de reparar o dano, representou a preocupação do pensamento contemporâneo da sociedade em colocar a vítima no centro da discussão do instituto em testilha, proporcionando uma máxima garantia aos seus direitos, mormente a de ser indenizada sempre que sofra algum tipo de lesão.

Essa ideologia é extraída da própria Constituição Federal que, em matéria de responsabilidade civil, por meio da releitura do direito civil e da incidência dos princípios constitucionais da igualdade, solidariedade e dignidade da pessoa humana, tratou de objetivá-la, evoluindo, por conseguinte, do modelo individual-liberal para o modelo solidarista de Estado.

Impende destacar que, essa tendência pendular do direito também se manifestou com relação à responsabilidade civil dos pais pelos atos de seus filhos.

Com efeito, o direito romano, no início, desconhecia a noção de culpa como fundamento da responsabilidade civil, sendo que a responsabilidade civil do pater familias, nesse momento, era objetiva, o que lhe conferia, contudo, a possibilidade de abandonar o filho para a vítima (abandono noxal) caso não quisesse assumir o dever de indenizá-la. Era o princípio da noxalidade. Essa ideia também evoluiu com o aparecimento da culpa, o que trouxe a necessidade de a vítima provar esse elemento subjetivo, no caso concreto, para a eclosão do dever de reparar o dano. Nos tempos atuais, após o surgimento da presunção de culpa em favor da vítima, o nosso sistema, mais vanguardista, perfilhou expressamente a 
ideia da responsabilidade objetiva dos pais pelos atos de seus filhos menores por expressa disposição legal.

Demonstrou-se que o direito à indenização por danos à esfera patrimonial ou extrapatrimonial da pessoa é direito fundamental individual, porquanto inserido no art. $5^{\circ}$ da $\mathrm{CF} / 88$ que, em seus incisos $\mathrm{V}$ e $\mathrm{X}$ aduzem, respectivamente que "é assegurado o direito de resposta, proporcional ao agravo, além de indenização por dano material, moral ou à imagem" e "são invioláveis a intimidade, a vida privada, a honra e a imagem das pessoas, assegurado o direito à indenização pelo dano material ou moral decorrente de sua violação".

A presente dissertação partiu da seguinte constatação: o alcance prematuro da maioridade obtida pela pessoa, em comparação com o Código Civil de 1916, culminou com a assunção de responsabilidades dela pelos seus atos e a consequente liberação de seus progenitores em reparar os danos que seus filhos maiores de 18 anos ocasionem.

No entanto, conforme ressaltado, muitos filhos, hodiernamente, ainda que após o atingimento da maioridade, permanecem alguns anos coabitando com seus genitores e vivendo sobre a dependência econômica destes últimos.

Neste sentido, a antecipação da maioridade pode provocar e tem provocado, como noticiam os órgãos midiáticos, graves e insolúveis problemas para a ciência do direito, com vistas à possibilidade das pessoas, recém saídas da menoridade, praticarem atos contrários ao direito, ensejadores da eclosão de responsabilidade civil, sem o necessário aporte financeiro para arcarem com esse ônus.

Sublinhe-se, que o sistema se preocupa com a capacidade financeira da pessoa e, inclusive, pode-se afirmar ser o alcance da independência econômica, em alguns casos, um verdadeiro fato jurídico, em razão de sua relevância para o sistema, porquanto uma das formas de emancipação legal da pessoa depende da obtenção por parte da pessoa maior de 16 anos de economia própria, em razão de emprego ou de estabelecimento civil ou empresarial.

A emancipação voluntária, também, serviu como fundamento para esta dissertação, posto que a jurisprudência e a doutrina entendem, inobstante a inexistência de embasamento legal expresso, não ser capaz de isentar a responsabilidade civil dos pais pelos atos de seus filhos, nesta condição emancipados, pois, muitas vezes, há uma 
continuidade da dependência econômica dos descendentes perante seus genitores ainda que conquistadores da capacidade de fato. Portanto, vislumbra-se, mais uma vez, de acordo com essa circunstância, a importância para o sistema jurídico da independência econômica da pessoa. Isso, em nossa opinião, demonstra que, se a situação de dependência perdura a responsabilidade dos progenitores deve também permanecer.

Assim, o alcance da maioridade sem a esperada independência econômica do descendente cria um cenário fático muito semelhante à circunstância visualizada pela emancipação voluntária sem o real desprendimento dos filhos da vida econômica de seus genitores.

Dessa forma, seria contrário a um princípio fundamental de interpretação jurídica admitir que situações praticamente idênticas tenham sido reguladas pelo legislador de maneiras contraditórias, mormente se considerarmos que todo o ordenamento jurídico encontra-se embasado em princípios que, como é cediço, têm a função de conferir ao sistema coerência e unidade.

Procurou-se enfatizar que o ordenamento jurídico, a despeito de considerar o maior de 18 anos absolutamente capaz para o exercício de seus direitos, confere a ele algumas prerrogativas jurídicas, tratando-o de forma diferenciada ao possibilitar-lhe a continuidade do recebimento da pensão alimentícia mesmo após os 18 anos, entendimento este sumulado pelo STJ (súmula 358 do STJ).

Dessarte, o que ocorre é um prolongamento de um dos deveres inerentes ao poder familiar, qual seja, o dever de educação, o que evidencia que o alcance, por si só, da maioridade da pessoa não a desvincula, por completo, do plexo de efeitos jurídicos referentes à autoridade parental. Se há extensão do dever de educar, impende destacar que esta extensão não pode vir desacompanhada da necessária responsabilidade dos genitores, porquanto continuam presentes, na relação paterno filial, elementos da autoridade parental.

Esta tutela especial é sentida pela própria Lei no $8112 / 90$ que, em seu artigo 217, II, $a$, prevê a pensão destinada ao filho até os 21 anos de idade, a despeito de sua maioridade civil. No entanto, a jurisprudência, como enfatizado, tratou de estender essa prerrogativa até os 24 anos de idade, desde que a pessoa esteja freqüentando curso universitário.

Tentou-se demonstrar, por necessário, que o texto normativo é apenas o ponto de partida da implementação do Direito, sendo apenas um dos elementos necessários para a 
correta realização jurídica, permitindo sempre a sua interpretação de acordo com os anseios da sociedade.

Assim, cada vez mais a regra dos institutos absolutos vai se coadunando com as peculiaridades de cada caso, porquanto as normas jurídicas devem ser interpretadas de acordo com a realidade social, o que impõe, por conseguinte, uma flexibilização maior dos preceitos jurídicos, em homenagem aos valores irradiados pela Constituição Federal, mormente o do solidarismo social.

O atual Código Civil, em razão da adoção dos princípios da eticidade, socialidade e da operabilidade, aproximou-se da ética, pois passou a se preocupar não apenas com o titular de um direito subjetivo, mas também com aquele que sofre as consequências da realização de suas faculdades e permitiu uma maior abertura do sistema jurídico, propiciando mais liberdade ao aplicador do direito para a criação normativa.

Outro fator importante, para embasar o pensamento aqui tratado, é a abertura que a jurisprudência, ao longo do tempo, conferiu ao artigo que dispõe a respeito da responsabilidade civil indireta, ou seja, o artigo 932 do atual Código Civil, com uma forte tendência, inclusive por meio de súmula (492 do STF), a interpretá-lo de maneira a reconhecer que o seu rol é tratado como meramente enunciativo e não taxativo, fato este que permite, com maior facilidade, o desenvolvimento de outras hipóteses de responsabilidade civil indireta, como a que se defende nesta dissertação.

Fundamenta-se, outrossim, a idéia da responsabilidade civil dos pais pelos atos de seus filhos maiores, no fato de que a interpretação do artigo 932 do atual diploma civil, como um todo, traz a noção da subordinação e da dependência dos autores materiais do dano, em relação aos civilmente responsáveis pela indenização, noções que se subsumem plenamente à relação existente entre os pais e seus filhos maiores de idade que vivam sob sua dependência econômica.

Ora, o filho, nessas condições, está sob a autoridade dos pais vivendo com eles por serem os pais, na maioria das vezes, economicamente mais fortes. Essas situações se encaixam em várias das hipóteses existentes no artigo 932 do CC/2002 que, como explicitado, tem uma interpretação extremamente abrangente por parte da jurisprudência pátria, máxime em relação aos elementos referentes à responsabilidade civil do empregador. 
Ainda em relação ao artigo 932 do atual Código Civil, o termo autoridade, previsto em seu inciso I, apesar de aparentemente estar vinculado ao instituto do poder familiar, não pode ser restringido à relação jurídica estabelecida entre pais e filhos durante a menoridade destes últimos, haja vista que o inciso II, do referido artigo traz a expressão "nas mesmas condições", o que daria ensejo à assertiva de que uma vez não havendo o poder familiar, no caso de tutela ou curatela, o vocábulo autoridade necessariamente deveria ser interpretado de forma diversa, possibilitando uma leitura mais flexível do artigo 932, em relação à responsabilidade civil dos pais.

Assim, se pais têm autoridade em relação aos filhos, nas circunstâncias aqui ventiladas, seria possível subsumir estes fatos ao regramento que prevê a responsabilidade civil indireta dos genitores.

Ademais, a interpretação do artigo 932 do atual Código Civil tem se mostrado, muitas vezes, tão extensiva em favorecimento da vítima de um dano que, é possível chegar-se à conclusão de que nem todos os requisitos constantes em cada um dos seus incisos devem estar realmente presentes, para o surgimento do dever de indenizar do civilmente responsável. Pense-se no vocábulo companhia, previsto no inciso I, do referido artigo, e que, para muitos autores, acaba sendo dispensável para a eclosão da obrigação de indenizar do genitor não guardião em caso de pais separados.

Ora, se esse elemento (companhia) não é imprescindível, poder-se-ia afirmar, pela mesma razão que, caso estejam presentes a autoridade e companhia, nos moldes aqui tratados, a menoridade do filho seria passível de prescindibilidade para o surgimento do dever do seu genitor reparar um dano causado por aquele descendente capaz.

Essa maior abertura do sistema normativo, como foi estudada, se expressa como uma das características (princípio da operabilidade) do atual Código Civil que, diferentemente do vetusto codex, é repleto de cláusulas gerais e conceitos jurídicos indeterminados, que exigirão do aplicador da norma o preenchimento desses institutos com os valores mais consentâneos à sociedade, principalmente por meio da aplicação dos princípios constitucionais expressos ou implícitos que galgaram uma posição de maior destaque, a partir da consagração do pós-positivismo perante o nosso Direito.

A previsão do conceito legal indeterminado da atividade de risco, no parágrafo único do art. 927 do atual Código Civil, permitirá a extração de soluções mais compatíveis 
com a proteção da vítima, não podendo ser afastada a ideia, aprioristicamente, como explicitado pelo próprio Silvio Rodrigues ao dissertar acerca da responsabilidade civil dos pais, de que os genitores, quando colocam um filho no mundo, assumem o risco de que ele venha, em algum momento de sua vida, causar prejuízo a outrem, o que redundará na obrigatoriedade da reparação dos danos.

O desenvolvimento do poder familiar, em nossa opinião, é também uma atividade de risco e, se ocorre o seu prolongamento em virtude das circunstâncias em debate, os progenitores devem se responsabilizar por eventuais prejuízos ocasionados por seus filhos mesmo que capazes.

Demais disso, pode-se retirar a ilação de que a atividade que os pais praticam de a todo o momento celebrar contratos com seus filhos, sabendo, a priori, da incapacidade financeira de seus descendentes, também coloca em risco a alheia esfera jurídica de direitos, o que redunda na obrigatoriedade dos pais de indenizarem os danos, eventualmente causados por seus filhos.

A prevalência dos interesses da vítima mudou o foco de análise da responsabilidade civil, mostrando que o sistema se preocupa menos com o causador do dano e mais com o prejudicado. O próprio artigo 928 do atual diploma civil, como supracitado, trouxe a subsidiária responsabilidade do incapaz pelos prejuízos que ocasionar, dispositivo este que, em nossa opinião, é um dos que mais deixam patentes a prevalência da tutela ao lesado que deve sempre ser indenizado. Se o incapaz, que não tem capacidade de entender e de querer, pode vir a ter que indenizar alguém por um ato danoso que pratique, com mais razão o genitor, que foi o responsável pela educação e criação de seu filho poderá, subsidiariamente, ter a obrigação de indenizar, desde que presentes os outros requisitos aqui mencionados.

Outro ponto de suma importância para a fundamentação do objetivo desta dissertação, diz respeito ao contrato. Esse acordo de vontades com conteúdo patrimonial, assim como a sua principiologia, evoluiu a ponto de surgirem novas teorias, como a dos "Efeitos Externos dos Contratos" que se preocupa com os efeitos exteriores produzidos por esse negócio jurídico bilateral.

Com efeito, o princípio da relatividade dos contratos não se opera mais de maneira absoluta, o que permite que a vítima dos efeitos de um contrato, celebrado entre outros 
sujeitos de direito, possa buscar indenização frente aos contratantes, supedaneada no princípio da função social do contrato que possui dois níveis: o intrínseco, materializado no princípio da boa-fé objetiva, e o extrínseco.

Deveras, o contrato deve constituir, no nível extrínseco da função social, um instrumento que perfaça o desenvolvimento da sociedade, não podendo ser, por conseguinte, utilizado para causar prejuízo. Assim, esse negócio jurídico em debate deve ser não somente um instrumento de circulação de riquezas entre os contratantes, individualmente considerados, mas também uma forma de possibilitar o progresso social. As partes de um contrato devem observar sempre o bem comum e as consequências que a celebração desse acordo de vontades trará no seio social.

Ademais, a função social do contrato, nesse sentido, exige o emprego, por parte do hermeneuta, de valores jurídicos, morais, sociais e econômicos para ser adequadamente interpretada. O juiz decidirá de acordo com o que lhe for apresentado no caso concreto, não havendo prevista uma solução legal. O papel de criação do juiz, dessa maneira, é bem mais extenso, sendo múltiplas as soluções possíveis para o julgador, ao se deparar com a cláusula geral da função social do contrato, podendo até determinar indenização por quem não observou essa função.

Assim, as várias espécies de contratos formalizados entre pais e filhos, nas condições aqui tratadas, inserem-se, muitas vezes, na linha de desdobramento causal de eventuais atos ilícitos praticados pelos filhos maiores, economicamente dependentes de seus genitores, o que poderia redundar na responsabilidade, inclusive solidária, dos pais de indenizarem os danos provenientes desses contratos, máxime em razão do disposto no artigo 942 do Código Civil de 2002.

Procurou-se demonstrar, ainda, que o sistema civil não adota apenas a teoria da causalidade direta e imediata, no âmbito do nexo de causalidade, para estabelecer o liame de causa e efeito entre a conduta e o dano, porquanto há norma de abertura sistemática, prevista no artigo 935 do atual Código Civil, que prevê indiretamente a adoção da teoria da equivalência das condições, o que permite uma investigação e uma abrangência maior em relação ao responsável pelo dano.

Especialistas, na área da educação, enaltecem a importância dos pais na formação dos seus descendentes, sendo imperioso reconhecer que pesquisas comprovam que 
comportamentos inadequados dos filhos são reflexos de uma insuficiente atuação dos progenitores na criação e educação dos seus filhos.

O mau desempenho do poder familiar também pode ser causa de indenização arcada pelos pais, em vista de atos danosos de seus filhos, ainda que maiores. O alcance da maioridade do filho não pode premiar os progenitores com a exclusão da eventual obrigatoriedade de indenizar os danos causados por seus filhos maiores que vivem às suas custas.

Com efeito, procurou-se demonstrar que os pais estão adstritos à observação da imposição constitucional de criar e educar os seus descendentes. Não se pode olvidar que a autoridade parental deve ser exercida de forma responsável, de acordo com sua função social, posto que também tem esse instituto a finalidade de mediatamente assegurar à sociedade o ingresso de pessoas moralmente aptas ao convívio social, principalmente porque a formação da pessoa depende de um bom desempenho dos pais, no exercício do poder familiar.

Ante o exposto, pensamos, de todo modo, ter operado proficuamente no sentido de, sem maiores pretensões, lançar uma réstia de luz sobre a questão atinente à responsabilidade civil dos pais, de forma a contribuir, ainda que modestamente, para a evolução desse instituto que, a nosso ver, deve se compatibilizar com os caminhos irretornáveis traçados por esse importante ramo do direito das obrigações. Se a presente dissertação provocar discussões entre os operadores do direito, acerca da possibilidade da responsabilidade civil dos pais pelos atos ilícitos praticados pelos seus filhos capazes, nas condições aqui defendidas, os esforços de seu autor terão sido sobejamente recompensados. 


\section{REFERÊNCIAS BIBLIOGRÁFICAS}

AEDO BARRENA, Cristián. Los requisitos de la lex Aquilia, con especial referencia al daño: lecturas desde las distintas teorías sobre el capítulo tercero. Ius et Praxis, Universidad de Talca, año 15, n. 1, 2009.

AGUIAR JÚNIOR, Ruy Rosado de. Projeto do Código Civil: as obrigações e os contratos. Revista dos Tribunais, São Paulo, ano 89, v. 775, maio 2000.

ALEXY, Robert. Teoria de los derechos fundamentales. Madrid: Centro de Estudios Políticos y Constitucionales, 2002.

ALONSO, Paulo Sergio Gomes. Pressupostos da responsabilidade civil objetiva. São Paulo: Saraiva, 2000.

ALVES, Jones Figueirêdo. Código Civil comentado. Coordenadora Regina Beatriz Tavares da Silva. 6. ed. São Paulo: Saraiva, 2008.

ALVES, José Carlos Moreira. Direito romano. 14. ed. Rio de Janeiro, 2007.

O novo Código Civil brasileiro e o direito romano: seu exame quanto às principais inovações no tocante ao negócio jurídico. In: FRANCIULLI NETTO, Domingos; MENDES, Gilmar Ferreira; MARTINS FILHO, Ives Granda da Silva (Coords.). O novo Código Civil: estudos em homenagem ao Prof. Miguel Reale. São Paulo: LTr, 2003.

ALVES, Roberto Barbosa. Direito da infância e da juventude. São Paulo: Saraiva, 2005.

ALVIM, Agostinho. Da inexecução das obrigações e suas conseqüências jurídicas. 5. ed. São Paulo: Saraiva, 1980.

ALVIM, Arruda. A função social dos contratos no novo Código Civil. In: SIMPÓSIO SOBRE O NOVO CÓDIGO CIVIL BRASILEIRO. Coordenação Glauber Moreno Talavera; Lamera, Antonio Valdir Úbeda e Nelson Paisini. São Paulo: [s.n.], 2003.

AMARAL, Francisco. A interpretação jurídica segundo o Código Civil. Revista do Advogado, São Paulo, ano 28, n. 98, jul. 2008.

AMARAL NETO, Francisco dos Santos. Responsabilidade civil. In: FRANÇA, Rubens Limongi (Org.). Enciclopédia Saraiva do Direito. São Paulo: Saraiva, 1977. v. 65. 
ARAÚJO, Paulo Dóron Rehder de. Responsabilidade objetiva com base na culpa. In: HIRONAKA, Giselda Maria Fernandes; SIMÃO, José Fernando (Coords.). Ensaios sobre a responsabilidade civil na pós-modernidade. Porto Alegre: Magister, 2009. v. 2.

ASCENSÃO, José de Oliveira. Cláusulas gerais e segurança jurídica no Código Civil de 2002. RTDC: revista trimestral de direito civil, Rio de Janeiro, ano 7, v. 28, p. 77-92, out./dez. 2006.

A propriedade de bens imóveis na dialética do abuso e da função. In: DELGADO, Mário Luiz; ALVES, Jones Figueiredo (Coords.). Questões controvertidas: direito das coisas. São Paulo: Método, 2008. (Série Grandes Temas de Direito Privado, v. 7).

AZEVEDO, Álvaro Villaça. Responsabilidade civil-I. In: FRANÇA, Rubens Limongi (Org.). Enciclopédia Saraiva do Direito. São Paulo: Saraiva, 1977. v. 65.

Proposta de classificacão da responsabilidade objetiva: pura e impura. Revista dos Tribunais, Sao Paulo, v. 82, n. 698, p. 7-11, dez. 1993.

. Teoria geral das obrigações. 3. ed. São Paulo: Ed. Revista dos Tribunais, 1981.

; NICOLAU, Gustavo Rene. Código Civil comentado. Das Pessoas e dos Bens. Artigos 1 a 103. São Paulo: Atlas, 2007. v. 1.

AZEVEDO, Antonio Junqueira de. A caracterização jurídica da dignidade da pessoa humana. RTDC: revista trimestral de direito civil, Rio de Janeiro, v. 2, n. 9, p. 3-24, jan./mar. 2002.

O direito ontem e hoje: crítica ao neopositivismo constitucional e à insuficiência dos direitos humanos. Revista do Advogado, São Paulo, ano 28, n. 99, set. 2008.

BARCELLOS, Ana Paula de. A eficácia jurídica dos princípios constitucionais. Rio de Janeiro: Renovar, 2002.

BARROS JÚNIOR, Edmilson de Almeida. A responsabilidade civil do médico: uma abordagem constitucional. São Paulo: Atlas, 2007.

BARROSO, Lucas de Abreu. Novas fronteiras da obrigação de indenizar. In: DELGADO, Luiz Mario; ALVES Jones Figueiredo (Coords.). Questões controvertidas no novo Código Civil (Responsabilidade civil). São Paulo, 2006. v. 5.

BARROSO, Luís Roberto. Diferentes mas iguais: o reconhecimento das relações homoafetivas no Brasil. In: ROCHA, Maria Elizabeth Guimarães Teixeira; PFLUG, Samantha Ribeira Meyer (Coords.). Lições de direito constitucional em homenagem ao Professor Jorge Miranda. Rio de Janeiro: Forense, 2008. 
BARROSO, Luís Roberto. Neoconstitucionalismo e constitucionalização do direito (O triunfo tardio do direito constitucional no Brasil). In: SARMENTO, Daniel Antonio de Moraes; SOUZA NETO, Cláudio Pereira (Orgs.). A constitucionalização do direito: fundamentos teóricos e aplicações especificas. Rio de Janeiro: Lumern Júris, 2007.

BASTOS, Celso Ribeiro; MARTINS, Ives Gandra. Comentários à Constituição do Brasil. São Paulo: Saraiva, 1988. v. 1.

BECK, Ulrich. Sociedade de risco: rumo a uma outra modernidade. Tradução de Sebastião Nascimento. São Paulo: Ed. 34, 2010.

BENATTI, Francesco. A responsabilidade pré-contratual (com a correspondência entre os preceitos do direito italiano e português). Coimbra: Livr. Almedina, 1970.

BETTI, Emilio. Teoria geral do negócio jurídico. Coimbra: Coimbra Ed., 1969. t. 1.

BEVILAQUA, Clovis. Código Civil dos Estados Unidos do Brasil. 10. ed. atual. por Achilles Bevilaqua. São Paulo: Livr. Francisco Alves, 1954. v. 2 e v. 4.

Código Civil dos Estados Unidos do Brasil. São Paulo: Livr. Francisco Alves, 1917. v. 4.

Teoria geral do direito civil. 2. ed. São Paulo: Livr. Francisco Alves, 1929.

BITTAR FILHO, Carlos Alberto. Pátrio poder: regime jurídico atual. Revista dos Tribunais, Sao Paulo, v. 81, n. 676, p. 79-84, fev. 1992.

BOBBIO, Norberto. Da estrutura à função: novos estudos de teoria do direito. Tradução de Daniela Beccaccia Versiani, revisão de técnica de Orlando Seixas Bechara, Renata Nagamine. Barueri/SP: Manole, 2007.

A era dos direitos. Rio de Janeiro: Ed. Campus, 1992.

Teoria geral do direito. São Paulo: Martins Fontes, 2008.

BOMFIM, Silvano Andrade do. Bullying e responsabilidade civil: uma nova visão do direito de família à luz do direito civil constitucional. Trabalho premiado no $3^{\circ}$ Congresso do IBDFAM/SP, ocorrido nos dias 27, 28 e 29 de agosto de 2009, na cidade de São Paulo/SP.

BONAVIDES, Paulo. Curso de direito constitucional. 13. ed. São Paulo: Malheiros Ed., 2003.

BRUNO, Aníbal. Direito penal: parte geral. Rio de Janeiro: Forense, 1978. t. 1. 
CALAMANDREI, Piero. Direito processual civil. Campinas/SP: Bookseller, 1999. v. 3.

CALLIZO LÓPES, Maria Ángeles. Obligación legal de alimentos respecto de los hijos mayores de edad: análisis del Artículo 66 de la Ley 13/2006, de 27 de diciembre, de Derecho de la Persona. Revista de Derecho Civil Aragonés, Zaragoza, año 28, 2009.

CAMBLER, Everaldo. Curso avançado de direito civil: direito das obrigações. São Paulo: Ed. Revista dos Tribunais, 2001. v. 2.

CARBONNIER, Jean. Droit civil: les obligations. Paris: PUF, 2000. t. 4. t.

CARNELUTTI, Francesco. Instituições do processo civil. Tradução: Adrián Sotero De Witt Batista. Campinas/SP: Servanda, 1999. v. 1.

CARVALHO DE MENDONÇA, Manoel Ignácio. Doutrina e prática das obrigações. 2. ed. Rio de Janeiro: Francisco Alves, 1911. v. 2.

CAVALCANTI, Ana Elizabeth Lapa Wanderley. O exercício do poder familiar e a sociedade da informação. In: $O$ direito na sociedade da informação II. São Paulo: Atlas, 2009.

CAVALIERI FILHO, Sérgio. Programa de responsabilidade civil. 2. ed. 3. tir. São Paulo: Atlas, 2000.

Programa de responsabilidade civil. 7. ed. São Paulo: Atlas, 2007.

. Programa de responsabilidade civil. 8. ed. São Paulo: Atlas, 2008.

. Responsabilidade civil constitucional. Revista Forense, Rio de Janeiro, v. 348, dez. 1999.

CHAVES, Antônio. Responsabilidade civil. Rio de Janeiro: José Bushatsky Editor, 1972.

CHINELATO, Silmara Juny de Abreu. Tendências da responsabilidade civil no direito contemporâneo: reflexos no Código de 2002. In: DELGADO, Luiz Mario; ALVES Jones Figueiredo (Coords.). Questões controvertidas no novo Código Civil (Responsabilidade Civil). São Paulo, 2006. v. 5.

COELHO, Fábio Ulhoa. Curso de direito civil. 2. ed. São Paulo: Saraiva, 2006. v. 1. Curso de direito civil. São Paulo: Saraiva, 2006. v. 4. Curso de direito civil. São Paulo: Saraiva, 2004. v. 2. 
CORAPI, Diego. Tradizione romanistica e influeze di common law nell'evoluzione del diritto brasiliano. RTDC: revista trimestral de direito civil, Rio de Janeiro, ano 9, v. 34, abr./jun. 2008.

CORREIA, Alexandre; SCIASCIA, Gaetano. Manual de direito romano. 4. ed. São Paulo:Saraiva, 1961. v. 1.

COSTA, Judith Martins. O adimplemento e o inadimplemento das obrigações no novo Código Civil e o seu sentido ético e solidarista. In: FRANCIULLI NETTO, Domingos; MENDES, Gilmar Ferreira; MARTINS FILHO, Ives Granda da Silva (Coord.). O novo Código Civil: estudos em homenagem ao Prof. Miguel Reale. São Paulo: LTr, 2003.

CRETELLA JÚNIOR, José. Curso de direito romano. 4. ed. Rio de Janeiro: Forense, 1970.

CURY, Munir; SILVA, Antônio Fernando do Amaral; MENDEZ, Emílio García. Estatuto da Criança e do Adolescente comentado. 5. ed. São Paulo: Malheiros Ed., 2002.

D'ANTONIO, Daniel H. Responsabilidad paterna y patria potestad. In: MOSSET ITURRASPE, Jorge; D'ANTONIO, Daniel Hugo; NOVELLINO, Norberto José. Responsabilidad de los padres, tutores y guardadores. Buenos Aires: Rubinzal-Culzoni Editores, 1998.

DAVID, René. Lês grand systéme de droit contemporains. 7. ed. Paris: Dalloz, 1978.

DE CUPIS, Adriano. Commentario del Codive Civile. A cura di Antonio Scialoja e Giuseppe Branca. Libro Quatro delle Obligazioni. Bolgna: Nicola Zanichelli Editore, 1964.

DELGADO, Luiz Mario; ALVES Jones Figueiredo (Coords.). Questões controvertidas no novo Código Civil (Responsabilidade civil). São Paulo, 2006. v. 5.

DELMANTO, Celso. Código Penal comentado. 6. ed. Rio de Janeiro: Renovar, 2002.

DE RUGGIERO, Roberto. Instituições de direito civil. Atualizado por Paulo Roberto Benasse. 1. ed. Campinas: Bookseller, 1999. v. 1, v. 2 e v. 3.

DI PIETRO, Maria Sylvia Zanella. Direito administrativo. 20. ed. São Paulo: Atlas, 2007.

DIAS, José de Aguiar. Da responsabilidade civil. 9. ed. Rio de Janeiro: Forense, 1994. v. 1.

. Da responsabilidade civil. 9. ed. Rio de Janeiro: Revista Forense, 1944. v. 2. Da responsabilidade civil. Rio de Janeiro: Renovar, 2006. 
DIAS, Maria Berenice. Manual de direito das famílias. 4. ed. São Paulo: Ed. revista dos Tribunais, 2007.

DINIZ, Maria Helena. Código Civil anotado. 11. ed. São Paulo. Saraiva: 2002. . Curso de direito civil brasileiro. 12. ed. aum. atual. São Paulo: Saraiva, 1998. v.

7. Curso de direito civil brasileiro. 18. ed., São Paulo: Saraiva, 2002. v. 1.

. Curso de direito civil brasileiro: direito de família. 18. ed. São Paulo: Saraiva, 2002. v. 5.

. Curso de direito civil brasileiro: responsabilidade civil. 17. ed. São Paulo: Saraiva, 2003. v. 7.

- Curso de direito civil brasileiro: teoria das obrigações contratuais e extracontratuais. 23. ed. São Paulo: Saraiva, 2007.

Curso de direito civil brasileiro: teoria geral do direito civil. 24. ed. São Paulo: Saraiva, 2007.

DIREITO, Carlos Alberto Menezes; CAVALIERI FILHO, Sérgio. Comentários ao Código Civil. Da responsabilidade civil. Das preferências e privilégios creditórios. (arts. 927 a 965). Coordenador Sálvio de Figueiredo Teixeira. Rio de Janeiro: Forense, 2004. v. 13.

DUARTE, Nestor. Código Civil comentado. Coordenadora Regina Beatriz Tavares da Silva. 6. ed. São Paulo: Saraiva, 2008.

DWORKIN, Ronald. O direito como interpretação. In: TEIXEIRA, Anderson Vichinkeski; OLIVEIRA, Elton Somensi de (Orgs.). Correntes contemporâneas do pensamento jurídico. Barueri/SP: Manole, 2010.

ELIAS, Roberto João. Comentários ao Estatuto da Criança e do Adolescente. 3. ed. São Paulo: Saraiva, 2009.

ESPINOZA ESPINOZA, Juan. La influencia de la experiencia jurídica italiana en el Código Civil peruano en matéria de responsabilidad civil. Revista de la Facultad de Derecho de la Pontificia Universidad Católica del Perú, Lima, n. 56, dic. 2003.

FACHIN, Luiz Edson. O "aggiornamento" do direito civil brasileiro e a confiança negocial. In: (Coord.). Repensando fundamentos do direito civil contemporâneo. 2. tir. São Paulo: Renovar, 2000. 
FACHIN, Luiz Edson. Aspectos da racionalidade histórico-cultural do arquétipo inserido no Código Civil brasileiro de 2002. Revista do Advogado, São Paulo, ano 28, n. 98, jul. 2008.

FARO, Frederico Kastrup. Boa-fé objetiva e dever de cooperação: uma análise sob as óticas do exercício da autonomia privada e da execução do contrato. $R T D C$, Rio de Janeiro, ano 10, v. 38, abr./jun. 2009.

FAZANO, Haroldo Guilherme Vieira. Curso de direito civil brasileiro: parte geral: das pessoas, dos bens e dos fatos jurídicos. Campinas: Edições Ltda., 2006.

FERNÁNDEZ CRUZ, Gastón; LEÓN HILARIO, Leysser. La reedificación conceptual de la responsabilidad extracontratual objetiva. Revista de la Facultad de Derecho Pontifícia Universidad Católica del Perú, Lima, n. 58, 2004.

FERREIRA, Aurélio Buarque de Holanda. Novo Aurélio século XXI: o dicionário da língua portuguesa. 3. ed. Rio de Janeiro: Nova Fronteira, 1999. Verificar o nome correto do dicionário.

FERREIRA FILHO, Manoel Gonçalves. Direitos humanos fundamentais. 7. ed. São Paulo: Saraiva, 2005.

FIÚZA, César. Direito civil: curso completo. 11. ed. Belo Horizonte: Del Rey, 2008.

A principiologia contratual e a função social dos contratos. Ciência Jurídica ad Litteras et Verba, ano 22, v. 139, jan./fev. 2008.

FIÚZA, Ricardo. Novo Código Civil comentado. São Paulo: Saraiva, 2002.

FRAGOSO, Heleno Cláudio. Lições de direito penal: a nova parte geral. Rio de Janeiro: Foresne, 1987.

; HUNGRIA, Nelson. Comentários ao Código Penal. 6. ed. Rio de Janeiro: Forense, 1983. v. 1, t. 2.

FRANÇA, Rubens Limongi. Instituições de direito civil. 3. ed. São Paulo: Saraiva, 1994.

Manual de direito civil. São Paulo: Ed. Revista dos Tribunais, 1969. v. 4, t. 2.

FRANCIULLI NETTO, Domingos; MENDES, Gilmar Ferreira; MARTINS FILHO, Ives Granda da Silva (Coord.). O novo Código Civil: estudos em homenagem ao Prof. Miguel Reale. São Paulo: LTr, 2003.

GAGLIANO, Pablo Stolze; PAMPLONA FILHO, Rodolfo. Novo curso de direito civil: parte geral. 10. ed. São Paulo: Saraiva, 2008. v. 1. 
GAGLIANO, Pablo Stolze; PAMPLONA FILHO, Rodolfo. Novo curso de direito civil: responsabilidade civil. 4. ed. São Paulo: Saraiva, 2006. v. 3.

GAMA, Guilherme Calmon Nogueira da. Direito de família brasileiro: introdução. Abordagem sob a perspectiva civil-constitucional. São Paulo: Juarez de Oliveira, 2001.

GARCEZ NETO, Martinho. Prática de responsabilidade civil. Rio de Janeiro: Ed. Jurídica e Universitária, 1970. (Biblioteca Jurídica).

_. Responsabilidade civil no direito comparado. Rio de Janeiro: Renovar, 2000.

GODOY, Cláudio Luiz Bueno de. Código Civil comentado: doutrina e jurisprudência. Coordenador Ministro Cezar Peluso. 6. ed. São Paulo: Saraiva, 2007.

. Função social do contrato: os novos princípios contratuais. São Paulo: Saraiva, 2004. (Coleção Agostinho Alvim. Coordenação Renan Lotufo).

GOMES, Luiz Flávio. Aula. Programa Saber Direito. TV Justiça. Exibido em 30 jul. 2008.

GOMES, Luiz Roldão de Freitas. Elementos de responsabilidade civil. Rio de Janeiro: Renovar, 2000.

GOMES, Orlando. Contratos. 18. ed. Rio de Janeiro: Forense, 1998.

. Obrigações. 15. ed. Rio de Janeiro: Forense, 2000.

GONÇALVES, Carlos Roberto. Comentários ao Código Civil: parte especial: do direito das obrigações. São Paulo: Saraiva, 2003. v. 11.

Comentários ao Código Civil: parte especial: do direito das obrigações (artigos 927 a 965). Coord. Antonio Junqueira de Azevedo. São Paulo: Saraiva, 2003. v. 11.

. Direito civil brasileiro: parte geral. 6. ed. São Paulo: Saraiva: 2008. v. 1.

_. Direito civil brasileiro: responsabilidade civil. 3. ed. São Paulo: Saraiva, 2008. v.

4.

. Direito civil: parte geral. 10. ed. São Paulo: Saraiva, 2003.

. Direito de família. 13. ed. São Paulo: Saraiva, 2008. v. 2.

. Responsabilidade civil. 6. ed. São Paulo: Saraiva, 1995.

. Responsabilidade civil. 7. ed. São Paulo: Saraiva, 2002. 
GRECO FILHO, Vicente. Direito processual civil brasileiro. 15. ed. São Paulo: Saraiva, 2002. v. 2.

Manual de processo penal. 7. ed. São Paulo: Saraiva, 2009.

GRISARD FILHO, Waldyr. Guarda compartilhada: um novo modelo de responsabilidade parental. 4. ed. São Paulo: Ed. Revista dos Tribunais, 2009.

GROENINGA, Gisele Câmara. Guarda compartilhada: a efetividade do poder familiar. In: COLTRO, Antonio Carlos Mathias; DELGADO, Mario (Coords.). Guarda compartilhada. São Paulo: Método, 2009.

GUASTINI, Ricardo. Os princípios constitucionais como fonte de perplexidade. In: TEIXEIRA, Anderson Vichinkeski; OLIVEIRA, Elton Somensi de (Orgs.). Correntes contemporâneas do pensamento jurídico. Barueri/SP: Manole, 2010.

HARBELE, Peter. Hermenêutica constitucional: a sociedade aberta dos intérpretes da Constituição: contribuição para a interpretação pluralista e "procedimental" da Constituição. Tradução de Gilmar Ferreira Mendes. Porto Alegre: Sergio Antonio Fabris Editor, 2002.

HIRONAKA, Giselda Maria Fernandes Novaes. Contrato: estrutura milenar de fundação do direito privado. Revista do Advogado, São Paulo, ano 23, n. 8, dez. 2002.

Responsabilidade civil e contemporaneidade: retrato e moldura. In: HIRONAKA, Giselda Maria Fernandes Novaes; SIMÃO, José Fernando (Coords.). Ensaios sobre responsabilidade civil na pós-modernidade. Porto Alegre: Magister, 2009. v. 2.

. Responsabilidade pressuposta. Belo Horizonte: Del Rey, 2005.

Responsabilidade pressuposta: evolução de fundamentos e de paradigmas da responsabilidade civil na contemporaneidade. In: DELGADO, Luiz Mário; ALVES, Jones Figueirêdo (Coords.). Novo Código Civil: questões controvertidas. Responsabilidade Civil. São Paulo: Método, 2006. (Série Grandes Temas de Direito Privado, v. 5).

Sobre peixes e afeto: um devaneio sobre a ética no direito de família. In: PEREIRA, Rodrigo da Cunha (Coord.). Família e dignidade humana. In: CONGRESSO BRASILEIRO DE DIREITO DE FAMÍLIA, 5. Anais... Belo Horizonte: IBDFAM, 2006.

HORBACH, Carlos Bastilde. A nova roupa do direito constitucional: neoconstitucionalismo, pós-positivismo e outros modismos. In: ROCHA, Maria Elizabeth Guimarães Teixeira; PFLUG, Samantha Ribeira Meyer. Lições de direito constitucional em homenagem ao Professor Jorge Miranda. Rio de Janeiro: Forense, 2008. 
ITURRASPE, Jorge Mosset. El porqué de una responsabilidad paterna que margina la culpa. In: MOSSET ITURRASPE, Jorge; D'ANTONIO, Daniel Hugo; NOVELLINO, Norberto José. Responsabilidad de los padres, tutores y guardadores. Buenos Aires: Rubinzal-Culzoni Editores, 1998.

JESUS, Damásio E. de. Direito penal: parte geral. 10. ed. São Paulo: Saraiva, 1985. v. 1.

_. Imputação objetiva. 3. ed. São Paulo: Saraiva, 2007.

_Leis das Contravenções Penais anotada. 7. ed. São Paulo: Saraiva, 1999.

KARAM, Munir. Responsabilidade civil dos pais pelo fato do filho. In: FRANÇA, Ribens Limongi (Org.). Enciclopédia Saraiva do Direito, São Paulo: Saraiva, 1981. v. 65.

LEAL, Victor Nunes. Prefácio. In: TAVARES, Juarez. Teorias do delito. Demais dados (excluir).

LEBRUN, Jean-Pierre. Entrevista. Veja, São Paulo, ano 12, n. 49, ed. 2142, 09 dez. 2009.

LEITE, Eduardo de Oliveira. Grandes temas da atualidade: responsabilidade civil. Rio de Janeiro: Forense, 2006. v. 6.

. Temas de direito de família. São Paulo: Ed. Revista dos Tribunais, 1994.

LEMOS, Patrícia Faga Iglecias. Meio ambiente e responsabilidade civil do proprietário (análise do nexo causal). São Paulo: Ed. Revista dos Tribunais, 2008.

LEVADA, Carlos Antonio Soares. O abuso e o novo direito civil brasileiro. São Paulo: Revista Unianchieta, 2007.

LIMA, Alvino. Culpa e risco. 2. ed. São Paulo: Ed. Revista dos Tribunais, 1998.

. Da culpa ao risco. São Paulo: Empresa Gráfica da Revista dos Tribunais, 1938. . A fraude no direito civil. São Paulo: Saraiva, 1965.

A responsabilidade civil pelo fato de outrem. 2. ed. rev. e atual. por Nelson Nery Jr. São Paulo: Ed. Revista dos Tribunais, 2000.

LISBOA, Roberto Senise. Manual de direito civil. 3. ed. São Paulo: Ed. Revista dos Tribunais, 2003. v. 1.

. Manual de direito civil. São Paulo. Ed. Revista dos Tribunais, 2005.

. Manual de direito civil: obrigações e responsabilidade civil. São Paulo: Ed. Revista dos Tribunais, 2004. v. 2. 
LÔBO, Paulo Luiz Neto. Contrato e mudança social. Revista dos Tribunais, São Paulo, ano 84, v. 722, dez. 1995.

. Teoria geral das obrigações. São Paulo: Saraiva, 2005.

. Direito civil: famílias. São Paulo: Saraiva, 2008. v. 3.

; LYRA JÚNIOR, Eduardo Messias Gonçalves de (Coords.). A teoria do contrato e o novo Código Civil. Recife: Ed. Nossa Livr., 2003.

LOPES, Miguel de Serpa. Curso de direito civil. Rio de Janeiro: Freitas Bastos, 2000. v. 2. . Curso de direito civil. 8. ed. rev. atual. Rio de Janeiro: Freitas Bastos, 1996. v. 8.

. Curso de direito civil: fontes acontratuais das obrigações. Responsabilidade civil.

4. ed. Rio de Janeiro: Freitas Bastos, 1995. (Biblioteca Jurídica Freitas Bastos, v. 5).

LOPEZ, Teresa Ancona. O dano estético: responsabilidade civil. 2. ed. São Paulo. Ed. Revista dos Tribunais, 1999.

_. Princípio da precaução e evolução da responsabilidade civil. São Paulo: Quartier Latin, 2010.

LORENZETTI, Ricardo. La discrecionalidad del juez em el marco de la legislación. Revista de la Facultad de Derecho de la Pontifícia Universidad Católica del Peru, Lima, n. 55 , dic. 2002.

Fundamentos do direito privado. São Paulo: Ed. Revista dos Tribunais, 1998.

LOTUFO, Renan. Código Civil comentado: parte geral. São Paulo: Saraiva, 2003. v. 1.

. Da oportunidade da codificação civil. Revista do Advogado, São Paulo, ano 22, n. 68, p. 19-30, dez. 2002.

MACIEL, Kátia Regina Ferreira Lobo Andrade. Curso de direito da criança e do adolescente: aspectos teóricos e práticos. 3. ed. Rio de Janeiro: Lumen Juris, 2008.

MARINONI, Luiz Guilherme. Curso de processo civil: teoria geral do processo. São Paulo: Ed. Revista dos Tribunais, 2006. v. 1.

MARKY, Thomas. Curso elementar de direito romano. São Paulo: Bushatsky, 1971.

MARQUES, Claudia Lima. Contratos no Código de Defesa do Consumidor. 4. ed. São Paulo: Ed. Revista dos Tribunais, 2002. 
MARQUES, Claudia Lima. Contratos no Código de Defesa do Consumidor. 5. ed. São Paulo: Ed. Revista dos Tribunais, 2005.

MARQUES, José Frederico. Curso de direito penal: da infração penal. São Paulo: Saraiva, 1956. v. 2.

MAXIMILIANO, Carlos. Hermenêutica e aplicação do direito. 19. ed. Rio de Janeiro: Forense, 2003.

MEIRA, Silvio A. B. Legislação agrária romana. In: Novos e velhos temas de direito. 1. ed. Rio de Janeiro: Forense, 1973.

MEIRELLES, Hely Lopes. Direito administrativo brasileiro. 24. ed. São Paulo Malheiros Ed., 1999.

MEIRELLES, Jussara. O ser e o ter na codificação civil brasileira: do sujeito virtual à clausura patrimonial. In: FACHIN, Luiz Edson (Coord.). Repensando fundamentos do direito civil brasileiro contemporâneo. 2. tir. Rio de Janeiro: Renovar, 2000.

MELlO, Celso Antonio Bandeira de. Curso de direito administrativo. 17. ed. São Paulo: Malheiros Ed., 2004.

MELLO, Marcos Bernardes de. Teoria do fato jurídico (plano da existência). 16. ed. São Paulo: Saraiva, 2010.

MELO, Albertino Daniel de. A responsabilidade civil pelo fato de outrem nos direitos francês e brasileiro. 1. ed. Rio de Janeiro: Forense, 1972.

MIRABETTE, Julio Fabrini. Código Penal interpretado. 2. ed. São Paulo: Atlas, 2001.

MONTEIRO, Washington de Barros. Curso de direito civil: direito de família. 28. ed. São Paulo: Saraiva, 1990. v. 2.

Curso de direito civil: direito das obrigações: $2^{\mathrm{a}}$ parte. 21. ed. São Paulo: Saraiva, 1987.

Curso de direito civil: direito das obrigações: $2^{\mathrm{a}}$ parte. 28. ed. São Paulo: Saraiva, 1995. v. 5.

Curso de direito civil: parte geral. 39. ed. rev. e atual. por Ana Cristina de Barros Monteiro França Pinto. São Paulo: Saraiva, 2003.

Curso de direito civil: parte geral. 31. ed. São Paulo: Saraiva, 1993. v. 1. 
MORAES, Maria Celina Bodin de. A constitucionalização do direito civil e seus efeitos sobre a responsabilidade civil. In: SARMENTO, Daniel Antonio de Moraes; SOUZA NETO, Cláudio Pereira (Orgs.). A constitucionalização do direito: fundamentos teóricos e aplicações especificas. Rio de Janeiro: Lumern Júris, 2007.

O princípio da solidariedade. Disponível em: <www.idcivil.com.br/pdf/biblioteca9.pdf>. Acesso em: 07 maio 2009.

MOSSET ITURRASPE, Jorge. La culpa de los padres. In: MOSSET ITURRASPE, Jorge; D'ANTONIO, Daniel Hugo; NOVELLINO, Norberto José. Responsabilidad de los padres, tutores y guardadores. Buenos Aires: Rubinzal-Culzoni Editores, 1998.

. De la responsabilidad de los padres de un menor de más de 10 años, de 10 a 21 años. In: MOSSET ITURRASPE, Jorge; D'ANTONIO, Daniel Hugo; NOVELLINO, Norberto José. Responsabilidad de los padres, tutores y guardadores. Buenos Aires: Rubinzal-Culzoni Editores, 1998.

NADER, Paulo. Curso de direito civil: parte geral. 4. ed. Rio de Janeiro: Forense, 2007. v. 1.

NERY, Rosa Maria de Andrade. Introdução ao pensamento jurídico e à teoria geral do direito privado. São Paulo: Ed. Revista dos Tribunais, 2008.

NERY JUNIOR, Nelson. Contratos no Código Civil. In: FRANCIULLI NETTO, Domingos; MENDES, Gilmar Ferreira; MARTINS FILHO, Ives Granda da Silva (Coord.). O novo Código Civil: estudos em homenagem ao Prof. Miguel Reale. São Paulo: LTr, 2003 .

; NERY, Rosa Maria de Andrade. Código Civil comentado. 6. ed. rev. ampl. e atual. São Paulo: Ed. Revista dos Tribunais: 2008.

; __ Código de Processo Civil comentado e Legislação Extravagante. 10. ed. São Paulo: Ed. Revista dos Tribunais, 2007.

Constituição Federal comentada e legislação constitucional. São Paulo:

Ed. Revista dos Tribunais, 2006.

NICOLAU, Gustavo Rene. Efetiva aplicação da teoria do risco no Código Civil de 2002. In: DELGADO, Luiz Mário; ALVES, Jones Figueirêdo (Coords.). Novo Código Civil: questões controvertidas: responsabilidade civil. São Paulo: Método, 2006. (Série Grandes Temas de Direito Privado, 5).

NORONHA, E. Magalhães. Direito penal. 5. ed. São Paulo: Saraiva, 1968. v. 1. 
NORONHA, Fernando. Desenvolvimentos contemporâneos da responsabilidade civil. Revista dos Tribunais, São Paulo, ano 88, v. 761, p. 31-44, mar. 1999.

Direito das obrigações: fundamentos do direito das obrigações e introdução à responsabilidade civil. São Paulo: Saraiva, 2003. v. 1.

NOTÍCIAS MAGISNEUQUEN. Disponível em: $<$ http://magisneuquen.org/index.php?option=com_content $\&$ view=article $\& i d=367$ :jurisprud encia\&catid=59: civil\&Itemid=132\#, pesquisa efetuada no dia 9/08/2010, às 9:12 hrs>.

NUCCI, Guilherme de Souza. Código Penal comentado. 5. ed. São Paulo: Ed. Revista dos Tribunais, 2005.

NUNES, Rizzato. Curso de direito do consumidor. 4. ed. São Paulo: Saraiva, 2009.

PASSOS, J. J. Calmon de. O imoral nas indenizações por dano moral. Jus Navigandi, Teresina, ano 6, n. 57, jul. 2002. Disponível em: <http://jus2.uol.com.br/doutrina/texto.asp?id=2989>. Acesso em: 5 jun. 2010.

PEDROTTI, Irineu Antonio; PEDROTTI, William Antonio. Noções de direito civil: de acordo com o Código Civil de 2002. Campinas/SP: Harpia Ed., 2004.

PELUSO, Cezar, Ministro (Coord.). Código Civil comentado. Barueri/SP: Manole, 2007.

PEREIRA, Caio Mário da Silva. Instituições de direito civil. 12. ed. Rio de Janeiro: Forense, 2001. v. 5.

Instituições de direito civil. 9. ed. Rio de Janeiro: Forense, 1992. v. 3.

_. Instituições de direito civil. Contratos. Declaração unilateral de vontade. Responsabilidade civil. 7. ed. Rio de Janeiro: Forense, 1984. v. 3.

. Introdução ao direito civil: teoria geral do direito civil. 9. ed. Rio de Janeiro: Forense, 1985.

. Responsabilidade civil (de Acordo com a Constituição de 1988). 9. ed. Rio de Janeiro: Forense, 1999.

PEREIRA, Regis Fichtner. A responsabilidade civil pré-contratual: teoria geral e responsabilidade pela ruptura das negociações contratuais. Rio de Janeiro: Renovar, 2001.

PEREIRA, Rodrigo da Cunha. Direito de família: uma abordagem psicanalítica. Belo Horizonte: Del Rey, 1997. 
PEREIRA, Rodrigo da Cunha (Coord.). Família e dignidade humana. In: CONGRESSO BRASILEIRO DE DIREITO DE FAMÍLIA, 5. Anais... Belo Horizonte: IBDFAM, 2006.

PERELMAN, Chain. Ética e direito. Tradução Maria Ermantina Galvão. São Paulo: Martins Fontes, 2000.

PERLINGIERI, Pietro. Perfis do direito civil: introdução ao direito civil constitucional. 3. ed. Rio de Janeiro: Renovar, 2009.

PONTES DE MIRANDA, Francisco Cavalcanti. Fontes e evolução do direito civil brasileiro. 2. ed. Rio de Janeiro: Forense, 1981.

Tratado de direito privado. Rio de Janeiro: Borsoi, 1966. t. 3.

. Tratado de direito privado. São Paulo: Ed. Revista dos Tribunais, 1974. v. 1.

PORTELA, Jorge Guillermo. Los principios jurídicos y el neoconstitucionalismo. Díkaion: revista de fundamentación jurídica, Chia, Bogotá, año 23, n. 18, p. 34-54, dic. 2009.

PRUST, Laísa Weber; GOMIDE, Paula Inez Cunha. Relação entre comportamento moral dos pais e dos filhos adolescentes. Scielo Brazil. Disponível em: $<$ http://www.scielo.br/scielo.php?script=sci_arttext\&pid=S0103166X2007000100006\&lng=en\&nrm=iso\&tlng=pt>. Acesso em: 04 jan. 2011.

RAMOS, Carmem Lucia Silveira. A constitucionalização do direito privado e a sociedade sem fronteiras. In: FACHIN, Luiz Edson (Coord.). Repensando fundamentos do direito civil contemporâneo. 2. tir. Rio de Janeiro: Renovar, 2000.

REALE, Miguel. Lições preliminares de direito. 24. ed. São Paulo: Saraiva, 1998. . Novo Código Civil brasileiro. 3. ed. rev. e ampl. São Paulo: Ed. Revista dos Tribunais, 2003. . O Projeto do Código Civil. São Paulo: Saraiva, 1986. . Visão geral do novo Código Civil. In: . Novo Código Civil brasileiro. 3. ed. rev. e ampl. São Paulo: Ed. Revista dos Tribunais, 2003.

RIZZARDO, Arnaldo. Parte geral do Código Civil. 6. ed. Rio de Janeiro: Forense, 2008. . Responsabilidade civil. 3. ed. Rio de Janeiro: Forense, 2007.

ROCHA, J. V. Castelo Branco. O pátrio poder. 2. ed. São Paulo: Livr. e Ed. Universitária de Direito, 1978. 
RODRIGUES, Dárcio Roberto Martins. Contribuição para o estudo da responsabilidade por fato de terceiro no direito romano. 1996. Tese (Doutorado) - Faculdade de Direito, Universidade de São Paulo, São Paulo, 1996.

RODRIGUES, Lafayette. Direito de família. Atualizado com base no novo CC por Ricardo Rodrigues Gama. 1. ed. Campinas/SP: Russell, 2003.

RODRIGUES, Silvio. Direito civil: responsabilidade civil. 19. ed. São Paulo. Saraiva, 2002. v. 4.

Direito civil: dos contratos e das declarações unilaterais da vontade. 25. ed. São Paulo: Saraiva, 1997. v. 3.

Direito civil: parte geral. 26. ed. São Paulo: Saraiva, 1996.

Direito civil: parte geral. 30. ed. São Paulo: Saraiva, 2000. v. 1.

Direito civil: responsabilidade civil. 17. ed. São Paulo. Saraiva, 1999. v. 4.

ROSENVALD, Nelson. Código Civil comentado. Coordenador Cezar Peluso. Barueri/SP: Manole, 2007.

SAMPAIO, José Adércio Leite. Mito e história da Constituição: prenúncios sobre a constitucionalização do direito. In: SARMENTO, Daniel Antonio de Moraes; SOUZA NETO, Cláudio Pereira (Orgs.). A constitucionalização do direito: fundamentos teóricos e aplicações especificas. Rio de Janeiro: Lumern Júris, 2007.

SANTOS, Clilton Guimarães. Direito da infância e juventude. São Paulo: CPC, 2004.

SANTOS, Eduardo Sens. O novo Código Civil e as cláusulas gerais: exame da função social do contrato. Revista Brasileira de Direito Privado, São Paulo, n. 10, abr./jun. 2002.

SARLET, Ingo Wolfgang. Dignidade da pessoa humana e direitos fundamentais. 4. ed. rev. atual. Porto Alegre: Livr. do Advogado, 2006.

Mínimo existencial e direito privado: apontamentos sobre algumas dimensões da possível eficácia dos direitos fundamentais sociais no âmbito das relações jurídicoprivadas. In: SARMENTO, Daniel Antonio de Moraes; SOUZA NETO, Cláudio Pereira (Orgs.). A constitucionalização do direito: fundamentos teóricos e aplicações especificas. Rio de Janeiro: Lumern Júris, 2007.

Ubiqüidade constitucional: os dois lados da moeda. In: SARMENTO, Daniel Antonio de Moraes; SOUZA NETO, Cláudio Pereira (Orgs.). A constitucionalização do direito: fundamentos teóricos e aplicações especificas. Rio de Janeiro: Lumern Júris, 2007. 
SAVATIER, René. Traité de la responsabilité civile en droit français. Paris: LGDJ, 1939. t. 1.

SCHIER, Paulo Ricardo. Novos desafios da filtragem constitucional no momento do neoconstitucionalismo. In: SARMENTO, Daniel Antonio de Moraes; SOUZA NETO, Cláudio Pereira (Orgs.). A constitucionalização do direito: fundamentos teóricos e aplicações especificas. Rio de Janeiro: Lumern Júris, 2007.

SHREIBER, Anderson. Novos paradigmas da responsabilidade civil: da erosão dos filtros da reparação à diluição dos danos. 2. ed. São Paulo: Atlas, 2009.

SILVA, José Afonso da. Curso de direito constitucional positivo. 12. ed. São Paulo: Malheiros Ed., 1996.

SILVA, Regina Beatriz Tavares da (Coord.). Novo Código Civil comentado. 6. ed. rev. e atual. São Paulo: Saraiva, 2008.

SILVA, Wilson Melo da. Responsabilidade sem culpa e socialização do risco. Belo Horizonte: Ed. Bernardo Álvares, 1962.

SIMÃO, José Fernando. Fundamentos da responsabilidade civil: a responsabilidade do incapaz. In: HIRONAKA, Giselda Maria Fernandes; SIMÃO, José Fernando. Ensaios sobre a responsabilidade civil na pós-modernidade. Porto Alegre: Magister, 2009. v. 2.

Responsabilidade civil incapaz. São Paulo: Atlas, 2008.

. Responsabilidade civil pelo fato do animal: estudo comparativo dos Códigos Civis de 1916 e de 2002. In: DELGADO, Luiz Mario; ALVES Jones Figueiredo (Coords.). Questões controvertidas no novo Código Civil (Responsabilidade civil). São Paulo: Método, 2006. v. 5.

SOARES, Guido Fernando da Silva. Common law: introdução ao direito dos EUA. São Paulo: Ed. Revista dos Tribunais, 1999.

SOTOMAYOR, Maria Clara. Exercício do poder paternal: relativamente à pessoa do filho após o divórcio ou a separação de pessoas e bens. Porto: Publicações Universidade Católica, 2003. (Estudos e Monografias).

SOUZA NETO, Cláudio Pereira de; MENDONÇA, José Vicente Santos de. Fundamentalização e fundamentalismo na interpretação do princípio constitucional da livre iniciativa. In: SARMENTO, Daniel Antonio de Moraes; SOUZA NETO, Cláudio Pereira (Orgs.). A constitucionalização do direito: fundamentos teóricos e aplicações especificas. Rio de Janeiro: Lumern Júris, 2007. 
SOUZA NETO, João Batista de Mello. Direito civil: parte geral. 6. ed. São Paulo: Atlas, 2007. v. 1.

STOCO, Rui. A responsabilidade civil. In: FRANCIULLI NETTO, Domingos; MENDES, Gilmar Ferreira; MARTINS FILHO, Ives Granda da Silva (Coords.). O novo Código Civil: estudos em homenagem ao Prof. Miguel Reale. São Paulo: LTr, 2003.

— Tratado de responsabilidade civil. 5. ed. São Paulo: Ed. Revista dos Tribunais, 2001.

Tratado de responsabilidade civil. 6. ed. São Paulo: Ed. Revista dos Tribunais, 2004.

TEPEDINO, Gustavo. Notas sobre o nexo de causalidade. In: Temas de direito civil. Rio de Janeiro: Renovar, 2006. t. 2.

Temas de direito civil. 2. ed. Rio de Janeiro: Renovar, 2001.

A tutela da personalidade no ordenamento civil-constitucional brasileiro. In: . Temas de direito civil. Rio de Janeiro: Renovar, 2004.

(Coord.). A parte geral do novo Código Civil: estudos na perspectiva civilconstitucional. 3. ed. Rio de Janeiro: Renovar, 2007.

; BARBOZA, Heloísa Helena; MORAES, Maria Celina Bodin. Código Civil interpretado: parte geral e obrigações. Conforme a Constituição da República. 2. ed. São Paulo: Renovar, 2007. v. 1.

THEODORO JÚNIOR, Humberto. Comentários ao novo Código Civil: dos defeitos do negócio jurídico ao final do Livro III. Arts. 185 a 232. Coordenador Sálvio de Figueiredo Teixeira. Rio de Janeiro: Editora Forense, 2003. v. 3, t. 2.

O contrato e sua função social. Rio de Janeiro: Forense, 2003.

- Curso de direito processual civil: teoria geral do direito processual civil e processo de conhecimento. 50. ed. Rio de Janeiro: Forense, 2009. v. 1.

THEODORO NETTO, Humberto. Efeitos externos do contrato: direitos e obrigações na relação entre contratantes e terceiros. Rio de Janeiro: Forense, 2007.

TIMM, Luciano Benetti. Função social do direito contratual no Código Civil brasileiro: justiça distributiva vs. eficiência econômica. Revista dos Tribunais, São Paulo, ano 97, v. 876, out. 2008.

VALLER, Wladimir. A reparação do dano moral no direito brasileiro. 3. ed. Campinas/SP: E.V. Ed., 1995. 
Responsabilidade civil e criminal nos acidentes automobilísticos. 4. ed. Campinas/SP: Julex, 1993. t. 1.

VENOSA, Sílvio de Salvo. Direito civil: parte geral. 6. ed. São Paulo: Atlas, 2006. v. 1. . Direito civil: parte geral. 7. ed. São Paulo: Atlas, 2007. v. 1.

. Direito civil: responsabilidade civil. 3. ed. São Paulo: Atlas, 2003. Direito civil: responsabilidade civil. 8. ed. São Paulo: Atlas, 2008. v. 4.

WALD, Arnoldo. Obrigações e contratos. 12. ed. São Paulo: Ed. Revista dos Tribunais, 1995.

WAMBIER, Luiz Rodrigues; ALMEIDA, Flávio Renato Correia de; TALAMINI, Eduardo. Curso avançado de processo civil. 8. ed. São Paulo: Ed. Revista dos Tribunais, 2006. v. 1.

ZANCHIN, Kleber Luiz. Menos indenização na responsabilidade objetiva. In: HIRONAKA, Giselda Maria Fernandes Novaes; SIMÃO, José Fernando (Coords.). Ensaios sobre responsabilidade civil na pós-modernidade. Porto Alegre: Magister, 2009. v. 2.

ZIPPELIUS, Reinhold. Teoria geral do Estado. 3. ed. Lisboa: Fundação Calouste Gulbenkian, 1997. 